\title{
A MARKETINGSZERVEZET VÁLTOZÁSA A KÖZÖSSÉGI MÉDIA TÉRNYERÉSE NYOMÁN
}

\author{
Ph.D. értekezés
}

Témavezető: Dr. Bauer András, egyetemi tanár

Hubert József

Budapest, 2018 

HUBERT JÓZSEF

\section{A MARKETINGSZERVEZET VÁLTOZÁSA A KÖZÖSSÉGI MÉDIA TÉRNYERÉSE NYOMÁN}


Marketing és Média Intézet

Marketing Tanszék

Témavezető: Dr. Bauer András, egyetemi tanár

(C) Hubert József, 2018 


\title{
A MARKETINGSZERVEZET VÁLTOZÁSA A KÖZÖSSÉGI MÉDIA TÉRNYERÉSE NYOMÁN
}

\author{
Ph.D. értekezés
}

Témavezető: Dr. Bauer András, egyetemi tanár 



\section{TARTALOMJEGYZÉK}

I. TÉMA LEHATÁROLÁSA ÉS RELEVANCIÁJA .................................13

II. ELMÉLETI HÁTTÉR ....................................................................20

1. KÖZÖSSÉGI MÉDIA..........................................................................2 21

1.1. Definiálás, klasszifikáció ..........................................................21

1.2. Vállalati értékteremtés a közösségi média alkalmazásokkal ..............30

A vállalati közösségi média jelenlét alapelvei .......................................30

Kritikai elemzés, összefoglalás ........................................................40

2. SZERVEZET ELMÉLET.....................................................................42

2.1. Szervezeti konfiguráció - szervezeti teljesítmény - stratégia .............42

Szervezeti forma és struktúra ............................................................43

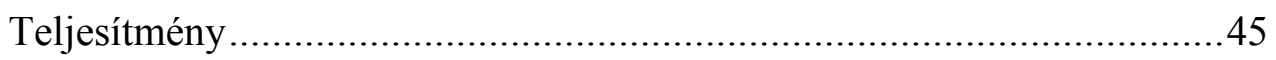

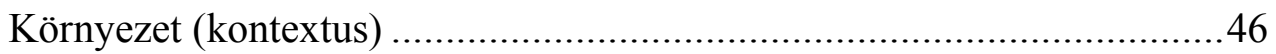

Tervezett vs. megvalósult stratégia .................................................48

Kritikai összegzés és a továbblépés szükségessége ..............................49

2.2. Ökoszisztéma, mint vállalati struktúra .............................................51

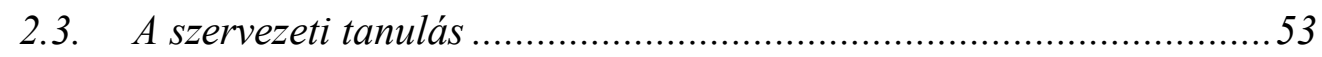

A szervezeti tanulás szintjei ..............................................................56

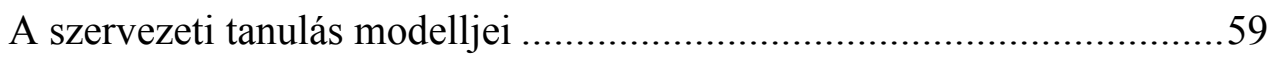

Marketing képességek és szervezeti tanulás .......................................60

A szervezeti tanulás és szervezeti struktúra kapcsolata...........................62

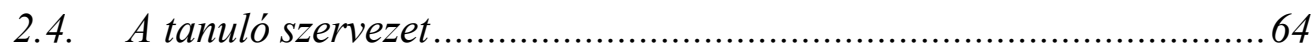

Tanuló szervezet és szervezeti felépítés, átalakítás...............................66

3. A DIGITALIZÁCIÓ ÉS A SZERVEZETEK ..................................................67

3.1. ERP/MIS rendszerek és szervezeti átalakulás..............................68

3.2. A közösségi média, mint diszruptív technológiai innováció ...............71

3.3. Közösségi média alkalmazások tudás igénye.................................. 78

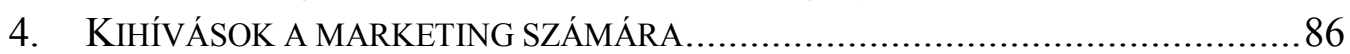

III. EMPIRIKUS KUTATÁS.................................................................96

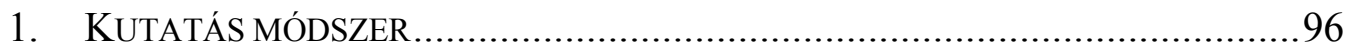

1.1. A kutatás célja .......................................................................96

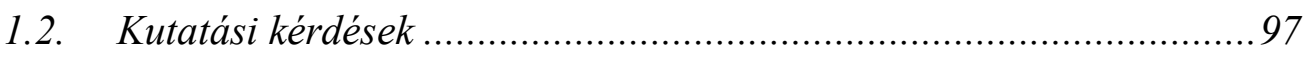

1.3. Kutatási módszertan .................................................................... 101

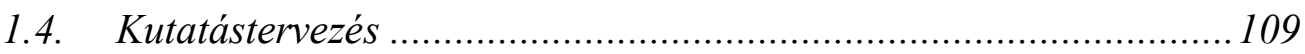

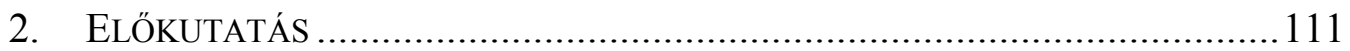

3. KUTATÁS ELSŐ FÁZISA: SZAKÉRTŐI MÉLYINTERJÚK...............................112

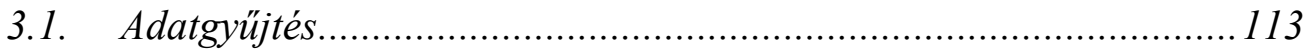

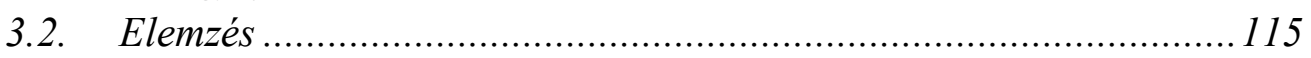

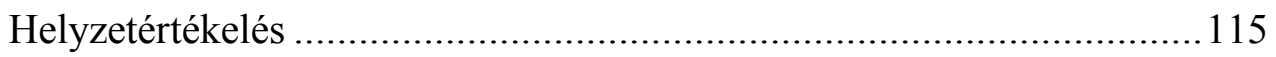


Marketing feladatok és hatáskörök................................................. 117

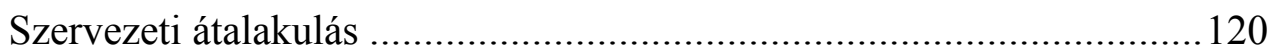

Szervezeti tanulás - tanuló szervezet .............................................. 121

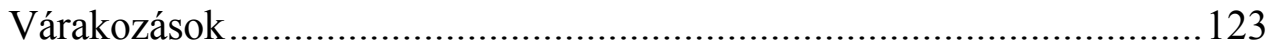

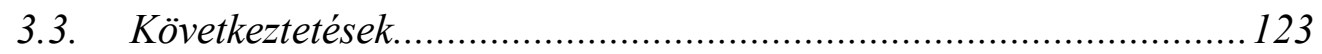

4. KUTATÁS MÁSODIK FÁZISA: PROJEKT MUNKA ELEMZÉSE ........................125

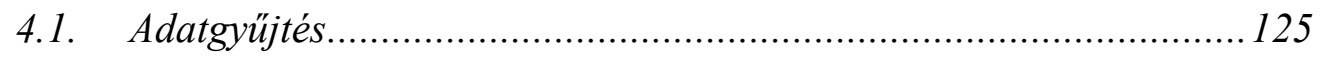

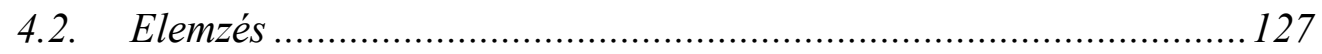

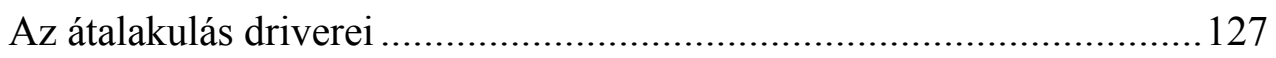

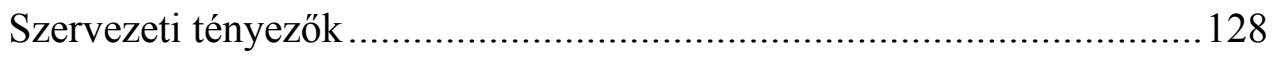

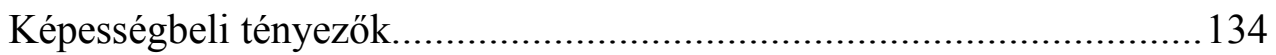

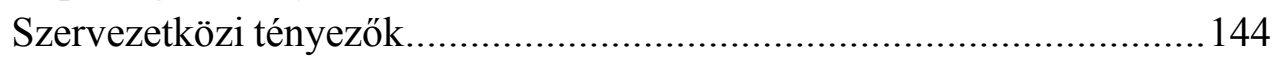

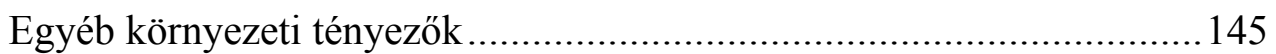

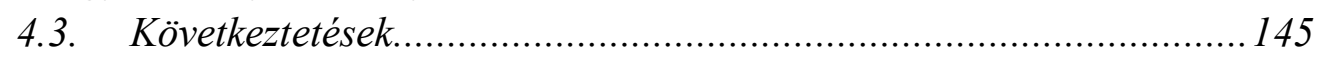

5. KUTATÁS HARMADIK FÁZISA: ÁLLÁSHIRDETÉS ADATBÁZIS ELEMZÉSE .....147

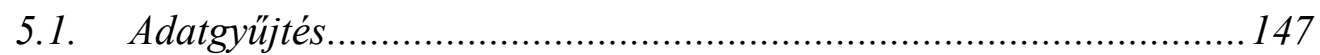

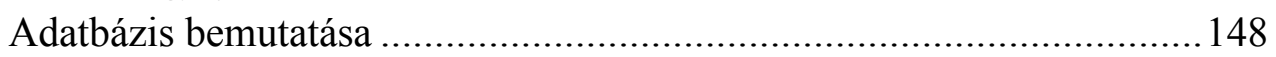

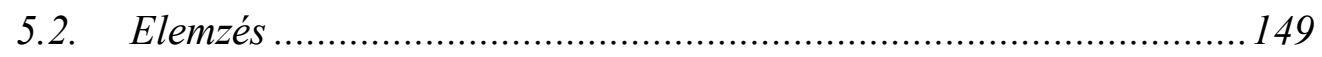

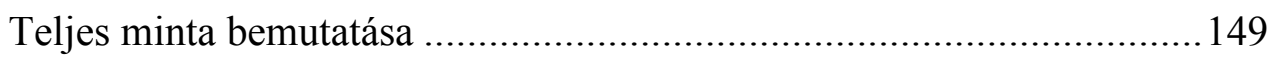

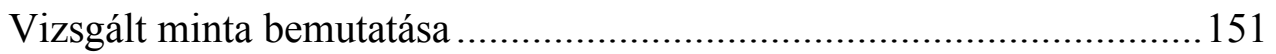

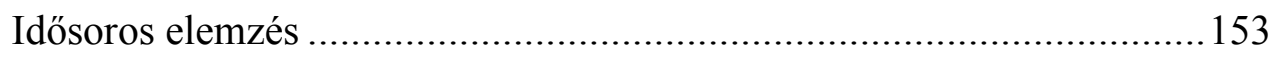

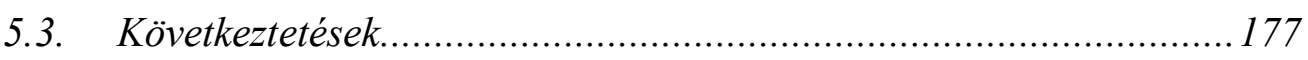

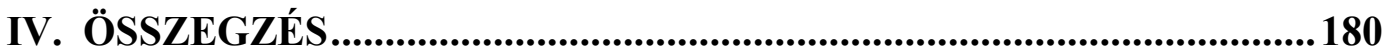

1. KUTATÁSI KÉRDÉSEK MEGVÁLASZOLÁSA, KÖVETKEZTETÉSEK..................180

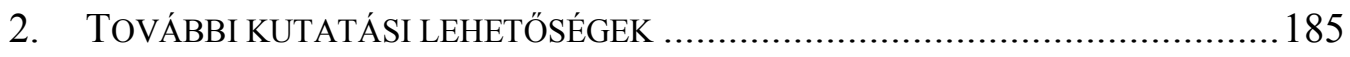

V. MELLÉKLETEK ..................................................................188

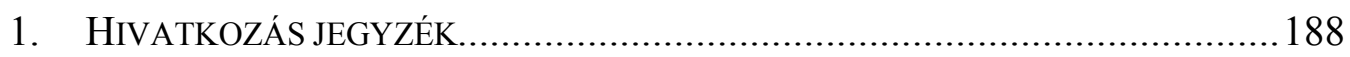

2. SZAKÉRTŐI MÉLYINTERJÚK VEZÉRFONALA..........................................203

3. VÁLLALATI ESETTANULMÁNY - FELADATKIÍRÁS ...................................205

4. KLASZTER * EGYÉB VÁLTOZÓK KERESZTTÁBLA......................................209 


\section{ÁBRÁK JEGYZÉKE}

Ábra 1. A digitális média eszközök használatának jelenlegi és várható szintje....14

Ábra 2: A disszertáció elméleti megalapozása ................................................20

Ábra 3: A közösségi részvétel hat alapelve.................................................. 31

Ábra 4: A közösségi médiában végzett marketing tevékenység hatásai a vevői értékre.

Ábra 5: Hagyományos marketing kommunikáció és a közösségi média kommunikáció hatása a vásárlási szándékra ................................................38

Ábra 6: Mintzbergi konfigurációs elmélet .......................................................43

Ábra 7: A szervezeti modellek jellemzői és alkalmazási feltételei.......................44

Ábra 8: Stabil és dinamikus környezet szervezeti konzekvenciái .......................48

Ábra 9: A stratégia típusai .......................................................................49

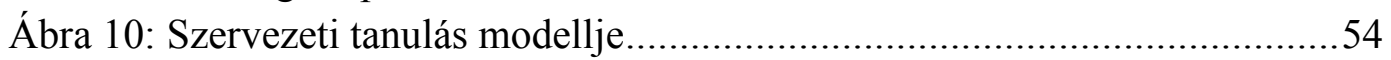

Ábra 11: A marketing képességek ................................................................61

Ábra 12: Szervezeti modellek és szervezeti tanulás .......................................63

Ábra 13: Teljes tanuló marketing szervezet ..................................................64

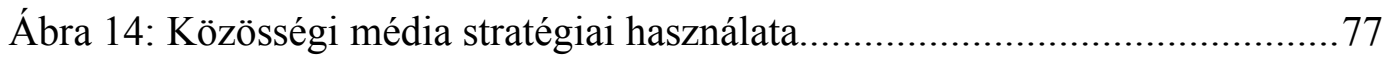

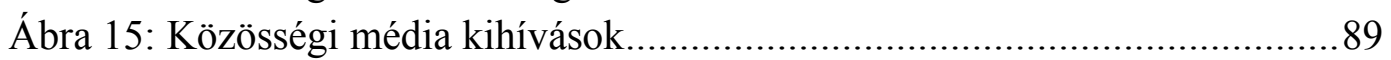

Ábra 16: „Napi internethasználók” Európában ..............................................90

Ábra 17:,,Mobil internethasználók" Európában .............................................91

Ábra 18: A digitális gazdaság és társadalom fejlettségét mérő mutató (DESI) 2017-es helyezések ...........................................................................91

Ábra 19: A DESI mutató relatív teljesítmény valamint időbeli megbontása ........92

Ábra 20: Elektronikus csatornán értékesítő vállalatok aránya az EU egyes tagállamaiban ...............................................................................92

Ábra 21: A webes forgalom aránya a teljes forgalom százalékában az EU egyes tagállamaiban....

Ábra 22: Közösségi média oldalak felhasználóinak aránya azok körében, akik az elmúlt 3 hónapban használták az internetet....................................................93

Ábra 23: A kutatás fogalmi kerete ............................................................97

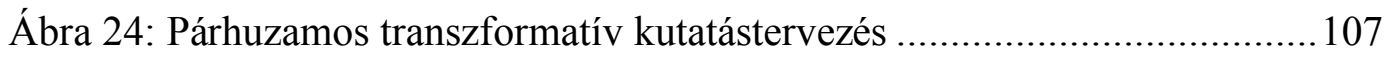

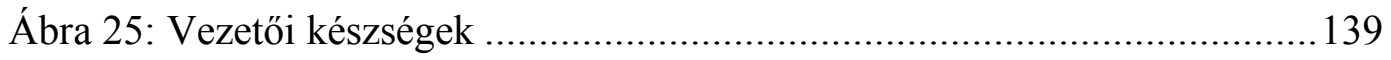

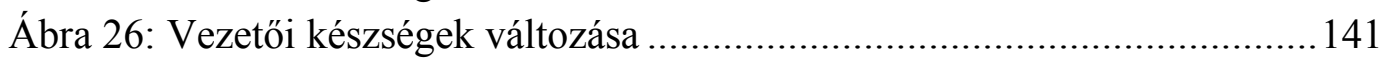

Ábra 27: Álláshirdetések száma és típusainak változása ................................. 151

Ábra 28: Álláshirdetés típusok kialakításának szemléltető ábrája..................... 154

Ábra 29: Az egyes álláshirdetés kategóriákban feladott hirdetések száma és aránya

Ábra 30: Álláshirdetések számának alakulása a válság alatt és azt követően.....156

Ábra 31: Az eltérő gyakorlati szintet megkövetelő álláshirdetések számának és arányának az alakulása

Ábra 32: Az eltérő tulajdonosi háttérrel feladott álláshirdetések számának és arányának az alakulása 
Ábra 33: A magyar és külföldi tulajdonú cégek száma és aránya a teljes mintán

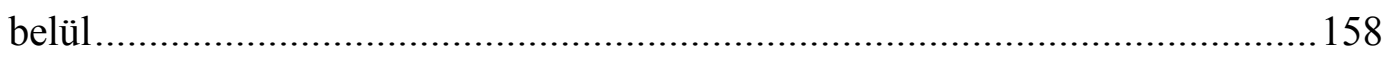

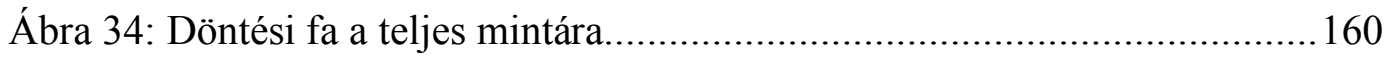

Ábra 35: Döntési fa a válság éveire vonatkozó almintára....................................163 


\section{TÁBLÁZATOK JEGYZÉKE}

Táblázat 1. Közösségi média definíciók áttekintése .........................................24

Táblázat 2: A közösségi média négy alkotóeleme...........................................24

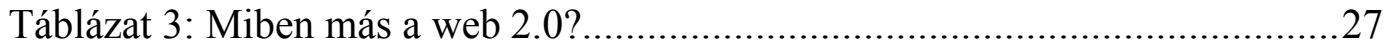

Táblázat 4: Közösségi hálózatok klasszifikációja..........................................28

Táblázat 5: Közösségi média szerepe a marketingtevékenységben....................28

Táblázat 6: Közösségi média egyes platformjainak használata a marketing

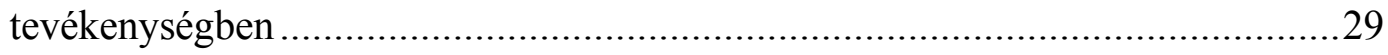

Táblázat 7: A közösségi média vállalati felhasználási területei ..........................33

Táblázat 8: Aktorok, szerepek a reputációval kapcsolatban a közösségi médiában

Táblázat 9: A fogyasztó szerepe a hagyományos és az új média esetében ...........41

Táblázat 10: A szervezeti tanulás modelljének tényezői ...................................56

Táblázat 11: A szervezeti tanulás egyes szintjeinek jellemzője .........................57

Táblázat 12: Hagyományos és tanulószervezetek összehasonlítása ...................66

Táblázat 13: Az ERP és a DSMM rendeszerek bevezetésének feltételezhető

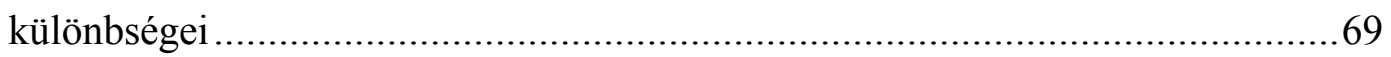

Táblázat 14: A közösségi média, mint diszruptív innováció..............................76

Táblázat 15: A közösségi média alkalmazások reklámstratégiai szempontjai ......85

Táblázat 16: A közösségi média által generált feszültségforrások ......................88

Táblázat 17: A magyarországi és az európai KKV-k jellemzői .........................94

Táblázat 18: A kvalitatív és kvantitatív kutatás összehasonlítása ..................... 104

19. táblázat: Kvalitatív és kvantitatív kutatások összevetése megbízhatóság, érvényesség és általánosíthatóság szempontjából....................................... 105

Táblázat 20: Kvalitatív kutatás mintaválasztási stratégiáinak tipológiája ..........109

Táblázat 21: Az empirikus kutatás fázisai................................................... 110

Táblázat 22: A kutatási kérdések és kutatási fázisok kapcsolata......................110

Táblázat 23: Az előkutatás során felmerült tényezők .....................................112

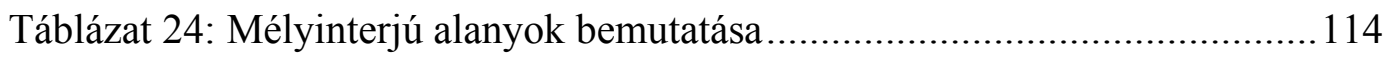

Táblázat 25: Az egyes médiumok jellemzése..............................................117

Táblázat 26: Munkavállalókkal szemben támasztott követelmények................119

Táblázat 27: Közösségi média osztály egy lehetséges szervezeti struktúrája .....121

Táblázat 28: Szervezeti tanulás és a közösségi média ...................................122

Táblázat 29: Mélyinterjúk során feltárt fontosabb szempontok ........................ 125

Táblázat 30: Vállalati esettanulmányok összefoglalása ..................................126

Táblázat 31: Esettanulmányok megírásához biztosított szempontrendszer ........ 127

Táblázat 32: A marketingszervezet átalakulása a "B" esetben .......................... 129

Táblázat 33: A marketingosztályok új feladatai .............................................132

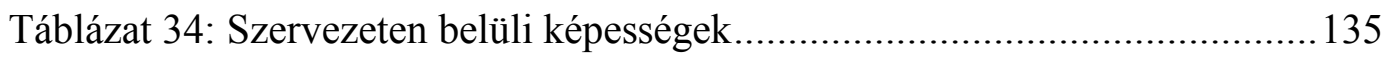

Táblázat 35: Szervezeti képességek és kihívások ........................................... 137

Táblázat 36: Vállalati esetekben feltárt fontosabb szempontok ....................... 147

Táblázat 37: Az adatbázisból származtatott változók .................................... 149 
Táblázat 38: Álláshirdetések számának évenkénti megoszlása........................150

Táblázat 39: Döntési fa összefoglaló táblázata.............................................. 162

Táblázat 40: A teljes mintára vonatkozó döntési fa ellenőrzése.........................162

Táblázat 41: A válság évei almintára vonatkozó döntési fa ellenőrzése............. 164

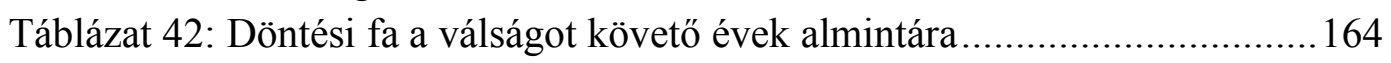

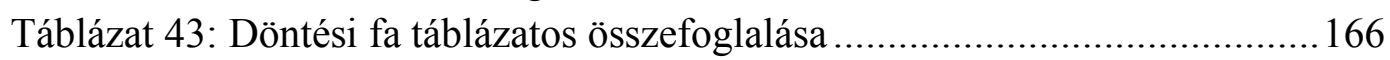

Táblázat 44:A válságot követő évek almintára vonatkozó döntési fa ellenőrzése

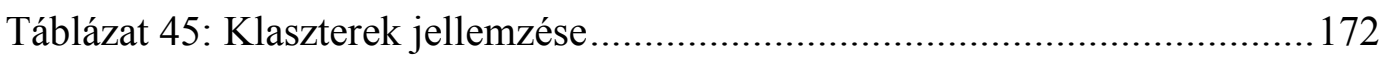

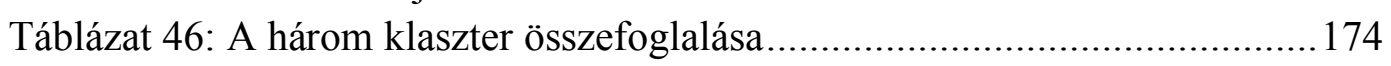

Táblázat 47: A klaszterek összefüggése más változókkal ..............................176

Táblázat 48: A kutatás harmadik fázisának legfontosabb megállapításai...........179 


\section{Téma lehatárolása és relevanciája}

Az új évezred első évtizedének derekán jelentek meg az első tanulmányok, melyek egy fontos átalakulásra mutattak rá: a „forradalmat” az első szerzők terminológiája nyomán web 2.0-ként határozták meg (szembe állítva a web 1.0-val, vagyis az internet „hagyományos” felhasználási formájával). A 2000-es évek első éveiben számos olyan alkalmazás született ${ }^{1}$, melyek azóta is a piac meghatározó szereplői. A felhasználók az első pillanattól milliós nagyságrendben özönlöttek az új platformokra, melyek egy sor szükségletükre kínáltak választ: társadalmi kapcsolatok kialakítása és ápolása, szórakozás, időtöltés, információ keresés és információ megosztás, önkifejezés, stb (Ellison et al., 2007).

Az internetnek egy új értelmezése is kialakult - nem függetlenül attól, hogy a világ népességének egyre magasabb hányada fér hozzá a világhálóhoz. A pusztán technikai (hálózatra, technológiára fókuszáló) megközelítés helyett az internet, mint szociológiai jelenség új, virtuális, a fizikai kontaktust nélkülöző kommunikációs térként is értelmezhető, ahol új rendszerek és platformok alakíthatóak ki, és jöttek is létre.

\footnotetext{
${ }^{1}$ Facebook: 2004 február; Twitter: 2006 március; Youtube: 2005 február; LinkedIn: 2003 május; Wikipedia 2001 január; Wordpress.com 2005 augusztus; Blog.hu: 2007; stb
} 


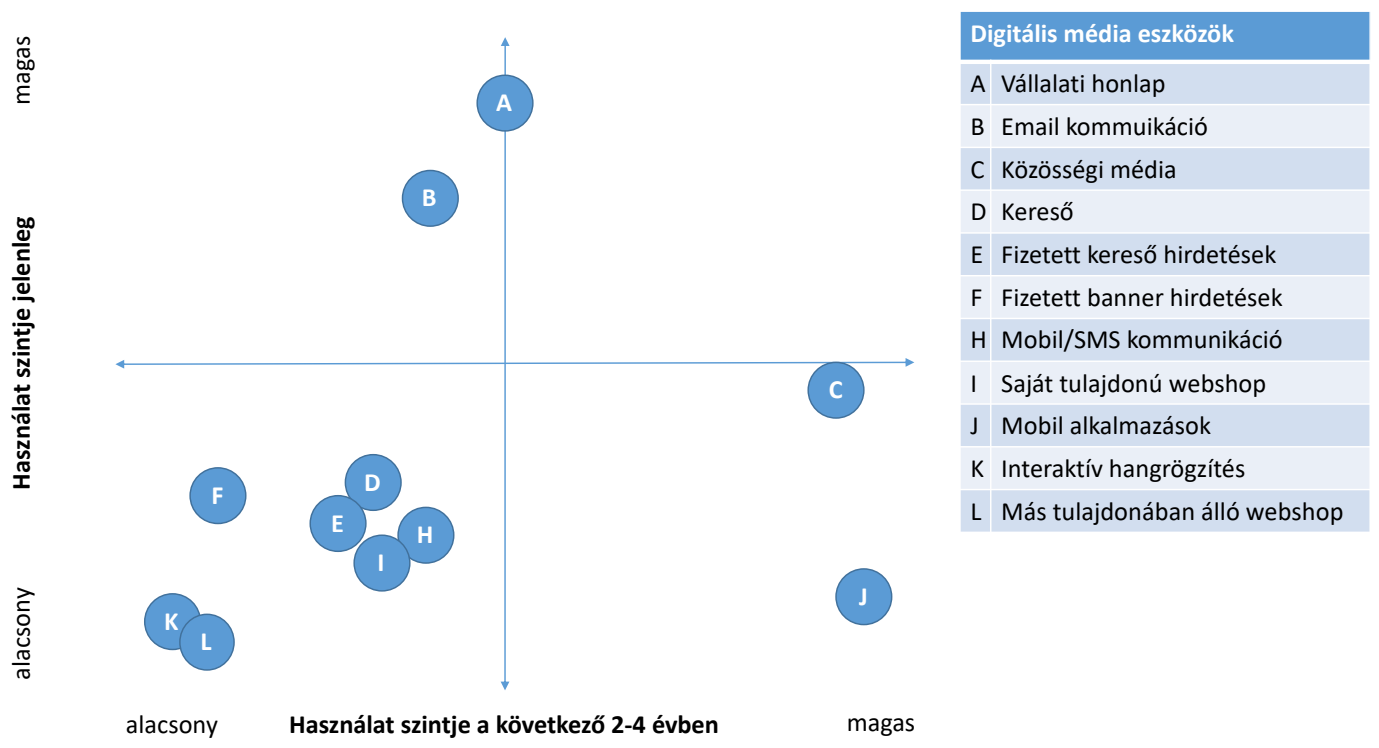

\section{Ábra 1. A digitális média eszközök használatának jelenlegi és várható szintje} Forrás: Leeflang et al. (2014), p3.

A megelőző kutatások azt mutatják, hogy a vállalati gyakorlat valamint a fogyasztói médiahasználat között jelentős diszkrepancia mutatkozik. Cégek a számukra kényelmes, saját tulajdonban levő és/vagy már megszokott csatornákat (pl. honlap, email marketing, stb) használják elöszeretettel. Eközben a fogyasztók egyre nagyobb számban mind több időt töltenek a közösségi médiában. Ebben az új közegben, mint az a jelen dolgozat elméleti áttekintés biztosító fejezetében bemutatásra kerül, sokszor a hagyományos médiumoknál megszokottól gyökeresen eltérő szabályok és logika érvényesül.

A téma fontosságát nem csak a növekvő felhasználáson mutatható meg. A Marketing Science Institute által felállított 2014-16 kutatási prioritások között ${ }^{2}$ szinte valamennyi kutatási kérdésnek van olyan, a szervezet által kiemelt vetülete, ami a közösségi médiához kapcsolódik (pl: fogyasztói élmény fejlesztése a közösségi médiában, létrehoz-e elkötelezettséget a közösségi média, a közösségi médiában keletkező strukturálatlan adatok analitikus elemzése, stb). Az újabb,

1. ${ }^{2} 2014-2016$ Research Priorities: http://www.msi.org/research/2014-2016-research-priorities/ Letöltve: 2018. 04. 26. 
2016-18-as kutatási prioritások között is számtalan olyan kérdés került megfogalmazásra, melyeknek a közösségi média és a digitális forradalom ágyazott meg, ill. azzal áll összefüggésben.

A közösségi médiával kapcsolatos kutatások különböző ágakra bomlanak. Lamberton-Stephen (2016) metakutatásában az ezredfordulótól 2016-ig négy korszak három nagy kutatási irányvonalát vette sorra (egyéni önkifejezés, internet mint eszköz, marketing információ forrás).

Ezen kívül egyéb kutatási témaköröket is beazonosíthatunk:

- Definíció és klasszifikálás (főként az első néhány évre volt jellemző téma. Például: Kaplan-Haenlein, 2010; O’Reilly, 2006; Thelwall, 2009; Levy, 2009; Erragcha - Romdhane, 2014; Ellison, 2007; stb)

- A web 2.0 használat módja és motivációi (Barefoot-Szabo, 2010; Lin et al., 2014; Sledgianowski-Kulviwat, 2009; Kim et al., 2010; Subrahmanyam et al., 2008; Kujath, 2011; Cheung et al., 2011; Ross et al., 2009; KussGriffiths, 2011; Raacke-Bond, 2008; stb)

- Anonimitás, személyes adatok védelme (Bronstein, 2014; Debatin, 2011; Walther, 2011; Papacharissi - Gibson; 2011; Luckerson, 2014; Yao, 2011; Zheleva-Getoor, 2009; stb)

- A vállalati célú felhasználás szintén központi helyet foglal el a kutatási agendán, igaz, a kutatók érdeklődése az elmúlt években fordul e felé a terület (pl: Lamberton-Stephen, 2016; Barger-Labrecque, 2013, Onishi Manchanda, 2012; Markos-Kujbus, 2016; Stephen et al., 2016; stb)

- Külön említésre érdemes még a web 2.0 alkalmazások és marketing hatékonyság közötti kapcsolatot elemző kutatások (pl. Luo et al, 2013; Stephen-Galak, 2012; stb)

Lamberton - Stephen (2016) metakutatásában az egyes publikációk idézettségét vizsgálva kimutatta, hogy az akadémiai kutatások homlokterében a word-of-mouth (WOM), közösségi hálózatok, döntési helyzetben segítséget nyújtó kutatások valamint a felhasználók által generált tartalmak (user generated content - UGC) áltak. A szerzők megjegyzik: az eddig elvégzett kutatások egy jelentős szelete 15 
egyetlen szük területre fókuszált: a WOM-ra. A helyzetet a kutatók szerint a téma gyakorlati relevanciája nem indokolja.

A téma fontosságát legjobban azzal lehet szemléltetni, hogy az elmúlt években milyen szerteágazó területeken mutatták meg kutatók a közösségi média - és általában a digitális marketing hatását az üzleti teljesítményre, illetve azt, hogy ezek a technológiák milyen jelentős változásokat eredményeztek a marketing egyes területein a kommunikációtól a stratégiaalkotásig.

Stephen et al. (2016) a közösségi hálózatok szerepét vizsgálta a fogyasztóktól érkező ötletek innovativitásában. Casalo et al. (2011) a fogyasztói magatartás területén vizsgált és mutatott ki gyökeres változásokat, melyeket egyértelmüen ezekhez a web 2.0 alkalmazás típusokhoz kötött. Yang et al. (2011) specifikusan a fogyasztói információ-keresés mintázatait tanulmányozva tárt fel összefüggést az online közösségek és a vásárlást megelőző információ-keresés mintázatai közt. Park - Kim hasonló változásról számol be ezen a területen (Park, Kim - 2009). Ez a változás irányát tekintve egybe vág a web 2.0 által a marketing egyéb területeire gyakorolt hatások irányával, vagyis ma a fogyasztók legfontosabb információforrása már nem a vállalati kommunikáció termékei, sokkal inkább a fogyasztók egymás közötti párbeszéde. Ennek a változásnak messze ható következményei lettek, melyek a cégek marketing- és kommunikációs tevékenységén túl szervezeti, strukturális, stratégiai és egyéb területeit is érintik.

Christodoulides, 2009 szerint a web 2.0 és a közösségi oldalak felvirágzása a vállalatok márkázási stratégiájára is kihatással van, a korábbi egyoldalú üzenetekkel szemben a szerző a felhasználókkal való 'együttgondolkodást', a márka által tematizált beszélgetések facilitálását javasolja. Fossel-Schweidel (2016) a közösségi tévézés (azaz a közösségi hálózatok valamint a tévé egyidejü használata) hatásait vizsgálta a hirdetési hatékonyságra.

Ezek csupán kiragadott példák, melyek a jelen kutatás fontosságát hivatottak alátámasztani és egyúttal kirajzolják az elmúlt évek fontosabb kutatási irányvonalait is. A lista ugyanakkor koránt sem teljes körü, többen vizsgáltak még olyan területeket, mint a közösségi média és a márkázás kapcsolata, a vírus 16 
kampányok sajátosságai, a szervezetek adaptációs képességei, szervezeti hatások, stb.

Ez a változás nem vállalat- vagy iparág-specifikus, a szakirodalmi kutatások alapján nem függ földrajzi helytől, a vállalatok formájától sem. Bronner - Hoog a turisztikai iparban mutatta ki a közösségi média hatását a fogyasztói magatartásra (Bronner - Hoog, 2014). Stephen - Galak a pénzügyi piacokon mutatta be, hogy a közösségi média mind az új, mind a meglevő vevők esetén képes értéket generálni a vállalatok számára, újabb eladások formájában (Stephen-Galak, 2012).

$\mathrm{Az}$ online szájmarketing (eWOM) kutatások terén szintén óriási robbanást figyelhetünk meg a szakirodalomban - ennek hátterében ismét csak a különböző web 2.0 alkalmazásokat fedezhetjük fel, melyek segítségével mérhetővé és elemezhetővé váltak a fogyasztók egymás közötti interakciói, párbeszédei és az információáramlás is. Trusov et al. például a közösségi médiában tett hivatkozások szerepét vizsgálta a weboldalok látogatottságának a növekedésében (Trusov et al, 2009), Onishi - Manchanda pedig a blogok és a televíziózás szerepét hasonlította össze bizonyos japán márkák értékesítésében (Onishi - Manchanda, 2012).

Akár az online, akár konkrétan a közösségi platformokon megvalósuló vállalati marketing aktivitás egy sor elönyt kínál a hagyományos marketing tevékenységekkel szemben. Az internet adta technológiai lehetőségek pontosabb szegmentálást, célzást - és ez által jobb pozicionálását tesznek elérhetővé (Akehurst, 2009), az információ áramlás felgyorsult sebessége mellett pedig óriási fogyasztói csoportok érhetőek el - (közel) valós időben (Van der Lans et al., 2010). Nem véletlen tehát, hogy kutatások azt igazolják: a hatékony 21. századi marketingstratégiában mind nagyobb szeletet hasítanak ki az online eszközök (LisHorst, 2013).

A vállalatok hozzáállását azonban sokszor a kivárás és bizonytalanság jellemzi ami a környezet folyamatos és dinamikus változása miatt nem meglepő. Az alkalmazásokra jellemző, hogy rövid életciklussal rendelkeznek - 3-5 év alatt „le 
tud csengeni” egy-egy újabb fogyasztói „hóbort”3, miközben a cégek számára sokszor különösen értékes fiatal vásárlói réteg folyamatosan új technológiák, alkalmazások felé áramlik. Bernoff-Li (2008) még informatikai szektorból is idéz példát, ahol a külső szemlélő számára „szakértő” cég nem mert belevágni a közösségi média jelenlétbe. Ennek egyik oka, amit a szerzők is kiemelnek, hogy a cégek ma érzik a nyomást magukon, hogy meg kellene jelenniük a közösségi felületeken, ám nehezen találják meg a saját hangjukat és szerepüket ebben az új közegben. Az elmúlt években ezen a területen nagy fejlődés volt tapasztalható, ma már sokkal mélyebb belátása van a témával foglalkozó szakértőknek, mint volt akárcsak 3-5 évvel ezelött.

A szakirodalomban ugyanakkor egyelőre kevés olyan kutatást találni, ami ezeknek a változásoknak a szervezeti konzekvenciáit vizsgálná meg, miközben több szerző (pl. Leeflang et al., 2014; Hamill, 2016; Choi-Thoeni, 2016, stb) is utal arra, hogy ez egy olyan jelentős kihívás, amire ma még nem állnak rendelkezésre iparági „,best-practise” forgatókönyvek.

Jelen disszertáció első fejezete a releváns szakirodalmi ismeretanyag, a megelőző kutatások legfontosabb megállapításainak összegzését nyújtja. A közösségi média fogalmi kereteinek tisztázását követően röviden érinti a legfontosabb vállalati alkalmazási területeket, majd bemutatja a szervezeti átalakulás kapcsolódó elméleti konstrukcióit. A kutatás szükebb környezete a magyar piac volt, ezért az elméleti rész a vállalati környezet kihívásainak ismertetését két irányból teszem meg: a közösségi média által jelentett kihívások mellett a magyar piac specialitásait is megmutatom.

Az elméleti áttekintést a kutatási kérdések megfogalmazása követi. Az empirikus kutatás három fázisból állt: szakértői mélyinterjúk, vállalati esettanulmányok

${ }^{3}$ Ezt nem csak a gyakorló szakemberek látják így. A Facebook tőzsdei bevezetése előtti napokban készült felmérés alapján az amerikaiak többség (51\%) A Facebook-ot is csupán mulandó hóbortnak (,fad”) gondolta. "Half of Americans Call Facebook a 'Fad,” Associated Press/CNBC, 2012, www.psfk.com/2012/05/americans-call-facebook-fad- headlines.html. 
feldolgozása, valamint a profession.hu-n marketing kategóriában 2010-18 között megjelent álláshirdetések tartalmi elemzése kvantitatív eszközökkel. 


\section{II.Elméleti háttér}

Jelen értekezés három különböző tudományterület eredményeire épít, és ezek metszéspontjának a vizsgálatára vállalkozik. Ezek mindegyike olyan (rész)terület a tudományon belül, mellyel sokan foglalkoznak, a metszetükre azonban már jóval kisebb figyelem jut.

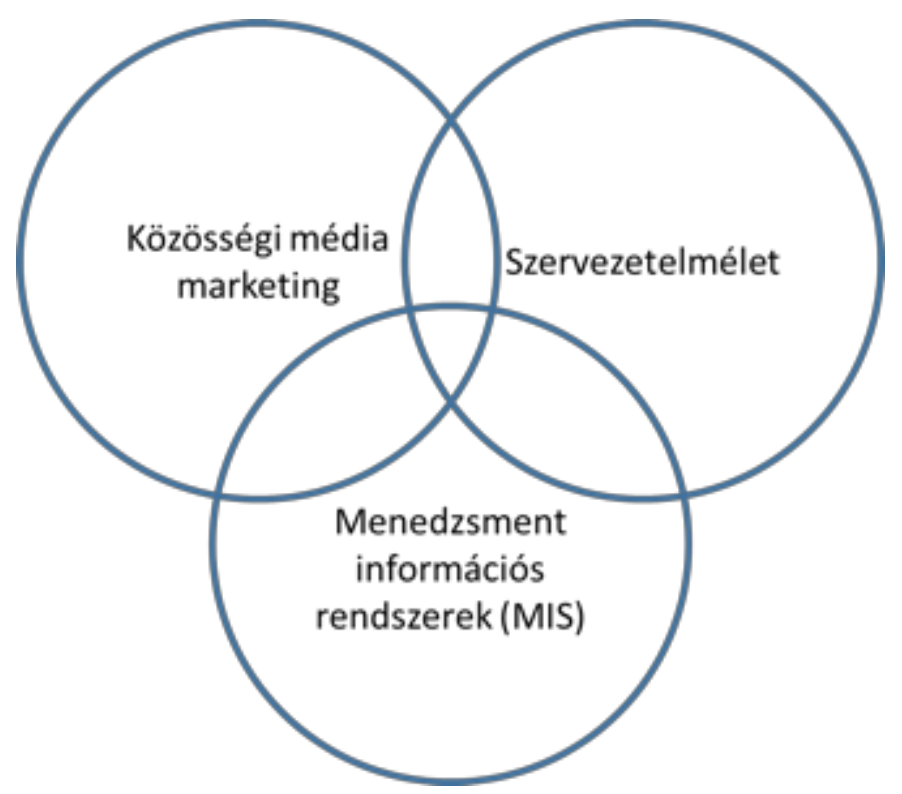

\section{Ábra 2: A disszertáció elméleti megalapozása}

Forrás: saját szerkesztés

A dolgozat első felében a közösségi média, a szervezeti változás, átalakulás, valamint a megváltozó menedzsment informatikai rendszerek releváns szakirodalmát tekintem át. A háttér bemutatása révén igazolni kívánom, hogy az ezeken a területeken tapasztalható változás komoly kihívások elé állítja a marketing szervezetet - ezen kihívások által indukált szervezeti, valamint egyéb konzekvenciák bemutatása három primer kutatás eredményeinek az ismertetésén keresztül történik majd a dolgozat második fejezetében. 


\section{Közösségi média}

\subsection{Definiálás, klasszifikáció}

Nem kérdés, hogy mivel a fogyasztók aktívan és egyre bővülö számban jelen vannak a közösségi médiában, így a cégek számára is az egyetlen járható út saját közösségi jelenlétük kialakítása. A múltban a marketing szakemberek email, DM, telemaketing, TV, rádió, stb útján osztották meg a céggel, termékekkel kapcsolatos információkat. A világhálón a marketing üzenetek oldalmegtekintések és hirdetések formájában jelentek meg, melyek révén nagy létszámú közönséget lehetett rövid idő alatt elérni. Ezek az eszközök természetesen nem tüntek el, de a témával foglalkozó kutatók egyhangú álláspontja szerint a közösségi média újszerủ megközelítésmódot igényel.

A szakirodalomban pontosan nyomon követhető a web 2.0 fogalmi definiálása: a szó ebben az értelmében elöször O'Reilly 2005-ben publikált cikkében bukkant fel, és már az első kutatások alapján nyilvánvaló volt, hogy:

- turbulens környezetről, folyamatosan mozgásban levő területről van szó, ahol új szereplők születnek és buknak meg, új kategóriák emelkednek ki és tünnek el

- habár alapvetően technológiai-műszaki hátterü területről van szó, ezeknek valójában a társadalomra gyakorolt hatása az, ami a társadalomtudományok, így a marketing kutatások fókuszában is áll.

A fogalmi keret tisztázásához elöször azt kell rögzíteni, hogy a terület fogalmai miként definiálhatók. Az első években használt, ma már csak ritkábban használt,,web 2.0”4 kézenfekvő definiálása - a nevéből is eredő módon - a web 1.0val való összehasonlításból adódik. Fehér (2012) pontosan erre a verziószám alapú

\footnotetext{
${ }^{4}$ A web 2.0 tágabb fogalom a közösségi médiánál. A következökben - mivel a téma vizsgálata szempontjából csak ez utóbbi a releváns - kizárólag a közösségi médiáról fogok beszélni.
} 
megkülönböztetésre utal, amikor a web 1.0 (avagy a „régi média”) kiváltójaként definiálja a web 2.0-át („új média”). A szerző maga is felhívja a figyelmet egy ellentmondásra - a web 1.0 kifejezés ugyanis csak később, a web 2.0 párjaként született meg.

O’Reilly egy kompakt definíciót kínál a web 2.0-ra:,AA web 2.0 egy üzleti forradalom a számítástechnika iparban, melyet az iparág internetre költözése idézett elő, és amely egy kísérletet jelent a siker feltételeinek megértésére ezen az új platformon. A legfontosabb szabály a következő: olyan alkalmazásokat készíts, melyek a javulás érdekében képesek használni a hálózati hatást, azért, hogy még több ember használja azokat. Ezt nevezzük a kollektív intelligencia kiaknázásának.” (O’Reilly, 2006, pp.1.)

A fenti definíció egyúttal egy új problémakörre világít rá, mellyel csak érintőlegesen foglalkozok. A közösségi média esetében a siker peremfeltételei nem adottak, mivel alapvetően más típusú logika mentén müködik, mint a korábban ismert médiaeszközök. A vállalat-fogyasztó kapcsolat szempontjából lényeges, hogy a változás mögött egy kommunikációs paradigma-váltást figyelhetünk meg. A közösségi média - szemben a hagyományos médiával - forradalmat hozott a kommunikáció áramlásának a menetében (Rényi, 2011). A - nevezzük így „hagyományos” web működési logikájából fakadóan jobban hasonlított a korábbi médiatípusokhoz (televízió, rádió, nyomtatott sajtó, stb):

- a hagyományos portálok, honlapok csak kevéssé ösztönöztek a felhasználói interakcióra.

- a tartalmat döntően a cég alkalmazottai állították elö, a felhasználók által előállított tartalom (user generated content - továbbiakban: UGC) nem volt az érdeklődés fókuszában.

- A kommunikációs modell a hagyományos, „broadcast” jellegü médiumokhoz hasonlóan egy (közlö) ->sok (befogadó) irányú

Ahhoz, hogy a kettő közötti különbséget megérthessük fontos tisztában lenni azok technológiai hátterével, illetve alapvető müködési mechanizmusaival. Szücs (2012) alapján az internet az az alap infrastruktúra, ami a világot átfogó hálózatot jelenti. 
Ezen müködik -egyebek (pl: e-mail, ftp, IP-alapú egyéb szolgáltatások, stb) mellett - a world wide web, ami a hiperlinkekkel összekapcsolt dokumentumokat jelenti (értelmezésemben ez a web 1.0). Ez a fajta technológia a korábbi médiumokban megismert korlátok többségét nem oldotta fel a marketing számára elérhető lehetőségek kiaknázásában. Herendy (2010) ezt úgy fogalmazta meg: az első korszakba online vállalati jelenléte továbbra is,,prospektus-jellegü”, vagyis többkevesebb rendszerességgel frissített weboldalakról szól, ahol:

- a fogyasztótól a vállalat felé irányuló visszajelzésheza használt kommunikációs csatorna megváltoztatására volt szükség (a weboldal helyett email vagy telefonhívás);

- a használt technológia hiába alkalmas a kétirányú kommunikációra (vállalat<->fogyasztó), a használat jellemző módja ezt nem aknázta ki, a felhasználókat pedig nem ösztönözték üzenetek megfogalmazására a honlapon keresztül;

- még kevésbé volt jellemző, hogy a felhasználók által írt üzeneteket a többi felhasználó számára is láthatóvá tegyék (sok<->sok irányú kommunikáció)

A következő táblázatban összefoglalóan bemutatok néhány definíciót, melyet a közösségi média megjelenését követő években - eltérő terminológiával (web 2.0, közösségi média, közösségi hálózat, stb) - állítottak össze a szerzők:

\begin{tabular}{|l|l|}
\hline Szerző & Definíció \\
\hline O’Reilly (2005) & \begin{tabular}{l} 
A web 2.0 olyan hálózat, amely a csatlakozó eszközöket \\
foglalja össze, az erre fejlesztett alkalmazások \\
kihasználják a platform által kínál előnyöket: \\
folyamatos fejlesztés, a csatlakozó emberek \\
számának növekedésével a hálózat is jobbá válik \\
adatok felhasználása eltérő forrásokból \\
- hálózati hatás \\
- gazdag felhasználói élményt nyújt \\
\hline $\begin{array}{l}\text { Constantinides- } \\
\text { Fountain (2008) }\end{array}$
\end{tabular} \mid $\begin{array}{l}\text { Nyílt, interaktív, felhasználók által szabályozott online } \\
\text { applikációk, melyek a tapasztalatok, tudás és a piac }\end{array}$ \\
\hline
\end{tabular}




\begin{tabular}{|c|c|}
\hline Szerző & Definíció \\
\hline & $\begin{array}{l}\text { megosztását teszik elérhetővé a résztvevőknek a } \\
\text { társadalmi és üzleti folyamatokban }\end{array}$ \\
\hline $\begin{array}{l}\text { Mangold-Faulds } \\
\text { (2009) }\end{array}$ & $\begin{array}{l}\text { Felhasználók által előállított (consumer-generated) } \\
\text { média }\end{array}$ \\
\hline Levy (2009) & $\begin{array}{l}\text { A korábbi internethasználathoz képest új, mert: } \\
\text { - az emberek és nem a kereskedelem áll a } \\
\text { középpontjában } \\
\text { - dinamikusabb } \\
\text { - könnyebb használat révén a tartalom előállítás, } \\
\text { publikálás szélesebb rétegek számára válik } \\
\text { elérhetővé }\end{array}$ \\
\hline $\begin{array}{l}\text { Kaplan-Haenlein } \\
(2010)\end{array}$ & $\begin{array}{l}\text { A web } 2.0 \text { a közösségi média fejlődésének a platformja, } \\
\text { a közösségi média olyan internet alapú alkalmazások, } \\
\text { melyek teret biztosítanak a felhasználók által generált } \\
\text { tartalom (UGC) előállítására és megosztására. }\end{array}$ \\
\hline
\end{tabular}

Táblázat 1. Közösségi média definíciók áttekintése

Forrás: Saját szerkesztés

Dahl (2018) a közösségi média négy alkotóelemét határozta meg, amelyek különkülön sajátos jellemvonásokkal bírnak, és ezek adják a közösségi médiában zajló vállalati (marketing) tevékenység egyedi jellegét.

\begin{tabular}{|l|l|l|l|}
\hline Szereplők & Média & Tartalom & Környezet \\
\hline Közös & Számítógép & Meggyőzés & Mérés \\
értékalkotás & Játékok & Bevonás & Kultúra-közi \\
$\begin{array}{l}\text { Szervezetek } \\
\text { Felhasználók és } \\
\text { csoportok }\end{array}$ & Mobil eszközök & Szájreklám & Etika és jog \\
\hline
\end{tabular}

Táblázat 2: A közösségi média négy alkotóeleme Forrás: Dahl (2018) p.5

A szerző által kínált „definíció” fontos szempontokra irányítja rá a figyelmet: 
- A kommunikációs modell megváltozása révén a felhasználói inputok a fogyasztók mélyebb integrációját teszik lehetővé a vállalati értékalkotásba;

- A közösségi média, mint üzenet hordozó és -közvetítő közeg már régen túl lépett a számítógépeken. Más szerzőknél is (ld., Lamberton-Stephen, 2016, Kaplan-Haenlein, 2010) tetten érhető, hogy a hagyományos informatikai eszközökön túl a közösségi média számára például a mobil eszközök és az online játékok is fontos szerepet játszanak;

- A mérés a hagyományos mérőszámokon túl kiterjedhet a fogyasztó pszichológiai (pl. hangulat), pszichográfiai (pl. életvitel, személyiségi jellemzők, társadalmi státusz) jellemzőire is, és ezek a vállalati döntéshozatal folyamán azonnal és készen felhasználható inputokká váltak

- A fogyasztó ilyen mély megismerésének egy másik következménye, hogy az komoly etikai és jogi aggályokat is fölvet (ld. Facebook - Cambridge Analytica botrány, EU GDPR szabályozás, stb);

A közösségi média által hozott változás egyik kulcsa kétségkívül a felhasználói felhatalmazás, azaz az internetezők immár nem csak a tartalmak fogyasztásában, de azok aktív előállításában is szerephez jutnak. A tartalmat kiterjesztett értelemben használom. Nem csak a honlapon, média felületeken megjelenő cikkek, képek, videó, stb - de a tartalmak megosztását is tartalomként értelmezem.

Decentralizált modell alakult ki, ahol a hálózat bonyolultsága növekedésnek indult (Fehér, 2012). Fontos kiemelni, hogy a fenti folyamatok nem csak hírcsatornák (híroldalak) esetében, de a cégek internetes jelenlétét biztosító egyes platformok (céges weboldal, közösségi hálózaton müködtetett saját oldalak, blogok, stb) estén is lezajlottak. Kaplan-Haenlein szintén a meglevő webes alkalmazások új szemléletű megközelítéseként értelmezi a közösségi médiát, ahol a tartalmat nem előállítják és publikálják, hanem a felhasználók (közösen) folyamatosan módosítják azt, egyfajta részvételi és kollaboratív megközelítésben (Kaplan-Haenlein, 2010). A szerzők definíciója szerint a közösségi média a web 2.0-ra épülő alkalmazások azon csoportja, melyek lehetővé teszik az UGC előállítását és megosztását. 
Menedzseri megközelítésben a közösségi média olyan alkalmazások és technológiák összessége, melyek elősegítik, hogy az azt használó fogyasztók a szervezetek értékláncába szervesen integrálódjanak, egymás között pedig hálózatokba tömörüljenek (ld. O’Reilly, 2005; Hass et al., 2008). Levy, 2009 három alapelvet emel ki, melyet a vállalatoknak figyelembe kell venniük a közösségi médiában: (1) webes platformon müködö alkalmazások, melyek fókuszában (2) szolgáltatások és nem alkalmazások fejlesztése áll, és melyek (3) aktív felhasználói közreműködésre építenek (a web2.0 központi fogalma, definíciós sarokköve a UGC). Az "aktív" ebben a kontextusban megtévesztő fogalom lehet, hiszen bizonyos webes alkalmazások szofisztikált technikai megoldásokat statisztikai módszerekkel ötvözve nyernek ki értékes adatokat a falhasználókból olyankor is, amikor azok egyébként pusztán passzívan böngészik az adott oldalt. Az internetes kereskedők, például az Amazon a látogatók számára prezentál ajánlásokat más, hasonló profillal rendelkező felhasználók múltbeli keresései és vásárlásai alapján.

Az már a kezdetektől egyértelmü volt, hogy a web 2.0 nem csak technológiában mutat eltérést a korábbi megoldásokhoz képest, hanem a közösség (felhasználók) bevonásával a müködési és ezzel együtt az üzleti logika is megváltozik. Ez tükröződik az O’Reilly (2005) által megfogalmazott nyolc alapjellemzőben, melyek a web 2.0 applikációk sajátjainak tekinthetőek:

\begin{tabular}{|c|c|}
\hline Alkalmazás jellemző & Üzleti konzekvencia \\
\hline & $\begin{array}{l}\text { Apró niché piacok kiaknázása a vevői } \\
\text { önkiszolgálás és algoritmikus adatmenedzsment } \\
\text { segítségével }\end{array}$ \\
\hline $\begin{array}{l}\text { (Nagy) } \\
\text { feldolgozása }\end{array}$ & Új insight-ok \\
\hline $\begin{array}{l}\text { A felhasználók } \\
\text { értéknövelő tényezőként } \\
\text { jelennek meg }\end{array}$ & $\begin{array}{l}\text { A korábbi „statikus” modellekkel szemben az } \\
\text { alkalmazások használói implicit és explicit értéket } \\
\text { generálnak, amit az alkalmazások fejlesztésében } \\
\text { szempontként megjelenik }\end{array}$ \\
\hline
\end{tabular}




\begin{tabular}{|c|c|}
\hline Alkalmazás jellemző & Üzleti konzekvencia \\
\hline Hálózati hatás & $\begin{array}{l}\text { A felhasználók csupán kis hányada ad értéket az } \\
\text { alkalmazáshoz, ezért készen kell állni a fogyasztói } \\
\text { bevonódás (adatfelhalmozás) ösztönzésére }\end{array}$ \\
\hline $\begin{array}{l}\text { Bizonyos } \\
\text { fenntartva }\end{array}$ & $\begin{array}{l}\text { Kollektív adoptáció nélkülözhetetlen feltétele, } \\
\text { hogy a jogtulajdonos a szellemi tulajdonjogok } \\
\text { bizonyos köréről lemondjon }\end{array}$ \\
\hline Örökös béta & $\begin{array}{l}\text { A szoftverfejlesztésben a folyamatos új } \\
\text { felhasználói élményt nyújtó szoftver tulajdonságok } \\
\text { hozzáadása a termékhez, a korábbi, nagy } \\
\text { egységekben érkező verzióváltások helyett }\end{array}$ \\
\hline $\begin{array}{l}\text { Ellenőrzés } \\
\text { együttmüködés }\end{array}$ & $\begin{array}{l}\text { A webszolgáltatások programozói csatlakozási } \\
\text { lehetőséget (interface) és adat szindikációt } \\
\text { kínálnak, illetve más rendszerek adataihoz is } \\
\text { hozzáférnek és azokat használják }\end{array}$ \\
\hline $\begin{array}{l}\text { Informatikai rendszer } \\
\text { helyett a szoftver a lényeg }\end{array}$ & Keresztplatform fejlesztés, mint követelmény \\
\hline
\end{tabular}

Táblázat 3: Miben más a web 2.0?

Forrás: O’Reilly (2005) alapján saját szerkesztés

A következő fejezetekben a fontosabb, leggyakrabban használt web 2.0 alkalmazások kerülnek bemutatásra: az elérhető legfrissebb használati statisztikák mellett a meglevő kutatások alapján a marketing számára fontos alkalmazási területek is ismertetésre kerülnek.

Kaplan és Haenlein, 2010 médiakutatási és a társadalmi folyamatok elméleti hátterére támaszkodva két dimenzió mentén hat különböző kategóriára bontja a közösségi hálózatok típusait, az ott előforduló UGC-tartalom média gazdagságának, illetve az azt használó felhasználók önkitárulkozásának szokásos mértéke alapján. 


\begin{tabular}{|c|c|c|c|c|}
\hline \multirow{5}{*}{ 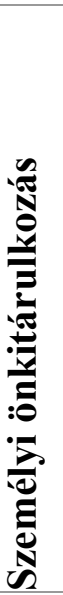 } & & \multicolumn{3}{|c|}{ Média tartalmi gazdagsága } \\
\hline & & Alacsony & Közepes & Magas \\
\hline & Magas & & $\begin{array}{l}\text { Közösségi oldalak } \\
\text { (pl. Facebook) }\end{array}$ & $\begin{array}{l}\text { Virtuális világok } \\
\text { (pl. Second Life) }\end{array}$ \\
\hline & Közepes & Virtuális közösségek & $\begin{array}{l}\text { Tartalom megosztók } \\
\text { (pl. Youtube) }\end{array}$ & \\
\hline & $\begin{array}{l}\text { Alacson } \\
\mathrm{y}\end{array}$ & $\begin{array}{l}\text { Közösségi projektek } \\
\text { (pl. Wikipedia) }\end{array}$ & & Online játékok \\
\hline
\end{tabular}

Táblázat 4: Közösségi hálózatok klasszifikációja

Forrás: Kaplan-Haenlein, 2010 alapján Minazzi (2015), pp.6.

A közösségi média vállalati felhasználását a szakirodalom szokás kétfelé bontani:

- a vállalati és/vagy marketing célok teljesülését aktívan támogató, proaktív jelenlét

- a fogyasztói, versenytársak viselkedését, véleményeit, megnyilvánulásait, értékelését, stb letapogató, passzív felhasználás mód (Felix et al., 2017)

Ez alapján a közösségi média használat az alábbi típusokra osztható fel:

\begin{tabular}{|l|l|l|}
\hline & Proaktív & Passzív/letapogató \\
\hline Értékesítési célú & $\begin{array}{l}\text { Közvetlen sales üzenet } \\
\text { küldése / DM }\end{array}$ & Lead generálás \\
\hline Márkázási célú & Imázs építés & $\begin{array}{l}\text { Fogyasztói adatok gyüjtése / } \\
\text { insight }\end{array}$ \\
\hline
\end{tabular}

Táblázat 5: Közösségi média szerepe a marketingtevékenységben

Forrás: saját szerkesztés

A vállalatok évről-évre bővülő mértékben vannak jelen a közösségi médiában. 2016-ban a CMO felmérés az Egyesült Államokban azt találta, hogy a reklámköltés 10 százalékát fordítják a cégek átlagosan a közösségi platformokra. A Fortune 500 cégek 73 százaléka rendelkezik Twitter, 66 százalék Facebook és 62 százalékuk YouTube csatornával. (Colicev et al., 2018). A vállalatok számára vonzó lehetőséget kínál, mivel valós időben, a közvetítő médiumok kiiktatásával 
közvetlenül kommunikálhatnak a fogyasztókkal, olcsóbban és hatékonyabban, mint a tradicionális médiában (Hassan et al., 2015).

A cégek a közösségi média különböző platformjait eltérő módon építhetik be a marketing tevékenységükbe. Dahl (2018) az alábbi kategóriákat határozta meg:

\begin{tabular}{|c|c|c|}
\hline & Felhasználási mód & $\begin{array}{l}\text { Példa } \\
\text { alkalmazás }\end{array}$ \\
\hline $\begin{array}{l}\text { Hagyományos } \\
\text { közösségi média } \\
\text { platformok }\end{array}$ & $\begin{array}{ll}\text { - } & \text { Új üzleti modellek } \\
\text { - Új } & \text { kommunikációs } \\
& \text { lehetőségek }\end{array}$ & $\begin{array}{l}\text { Facebook, } \\
\text { Amazon, } \\
\text { Twitter }\end{array}$ \\
\hline $\begin{array}{l}\text { Játék és hibrid } \\
\text { platformok }\end{array}$ & $\begin{array}{l}\text { - } \text { C2C kereskedelem (akár } \\
\text { virtuális termékekkel is) } \\
\text { - Játékon belül reklámok és } \\
\text { „advergaming” (a játék maga a } \\
\text { reklám) } \\
\text { - „Gamifikáció” (üzleti és egyéb } \\
\text { folyamatok játékosítása) } \\
\text { - Hipervalóság (virtuális és } \\
\text { „offline” valóságok közötti } \\
\text { határvonal elmosása) }\end{array}$ & $\begin{array}{l}\text { Second Life, } \\
\text { WorldsAway, } \\
\text { Pokemon Go }\end{array}$ \\
\hline $\begin{array}{l}\text { Mobil és } \\
\text { helymeghatározásra } \\
\text { épülő platformok }\end{array}$ & 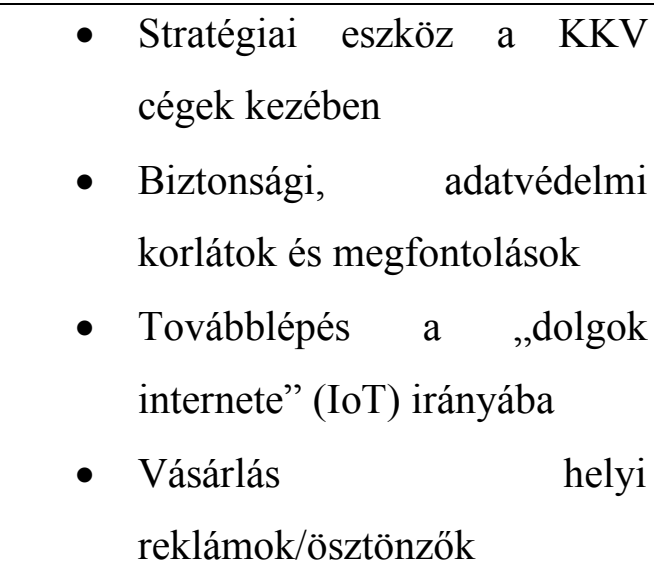 & $\begin{array}{l}\text { Google térkép, } \\
\text { Foursquare, } \\
\text { Swarm }\end{array}$ \\
\hline
\end{tabular}

Táblázat 6: Közösségi média egyes platformjainak használata a marketing tevékenységben

Forrás: Dahl (2018) alapján saját szerkesztés 
Azt a szerző is megjegyezi, hogy a fenti kategóriák nem egymást kizárók, szinte valamennyi nagyobb közösségi média alkalmazás fejlődik mindegyik irányba. A „játék” kategória némiképp kilóg, az első közösségi hálózatok valamint virtuális világok megjelenésekor sokkal dinamikusabb bővülést vártak a marketing terén ebben a kategóriában (pl. Second Life), ám annak teljesítménye inkább csalódást keltő.

A vállalati felhasználást erösíti, hogy a felhasználók egyáltalán nem idegenkednek a márkákhoz füződő kapcsolatukról beszélni Colicev és szerzőtársai azt találták, hogy a Facebook felhasználók 42 százaléka említett márkákat az állapotfrissítésében, míg a Twitter felhasználók üzeneteinek 19 százaléka tartalmazott utalást cégekre, márkákra. (Colicev et al., 2018). Más kutatások ugyanakkor azt mutatják, hogy a fiatalok elsősorban haszonelvü üzeneteket fogalmaznak meg a márkákról, és a márka - fiatal fogyasztói interakciók csupán 40 százalékát motiválják szimbolikus vagy rekreációs megfontolások (Hamilton et al., 2016).

\subsection{Vállalati értékteremtés a közösségi média alkalmazásokkal}

A közösségi média vállalati célú felhasználásának vizsgálatát két alapelv mentén tesszük meg. Először áttekintjük azokat a legfontosabb tényezőket, melyek a szakirodalom alapján a sikeres közösségi média stratégia szükséges (de nem minden esetben elégséges) feltételei, majd ezt követően pedig az értékteremtés módszereit vizsgáljuk meg. Végül néhány fontosabb pénzügyi mutatóról ejtünk szót, melyek alapján az értékteremtés sikeressége megítélhető.

\section{A vállalati közösségi média jelenlét alapelvei}

Bradley (2011) modelljében az alábbi 6 közösségi alapelvet javasolja a vállalatok közösségi médiában való részvételének alapjául: 


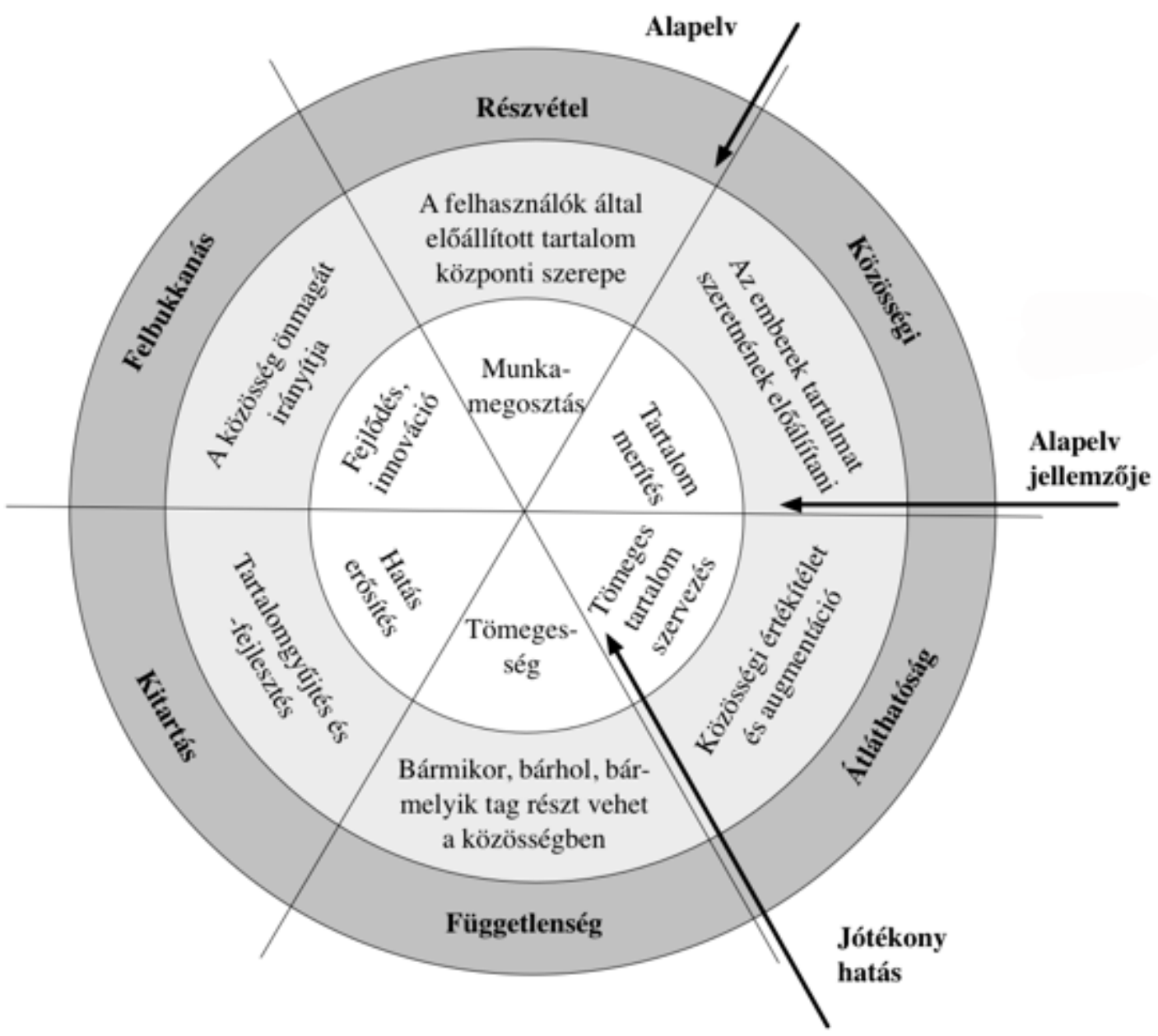

\section{Ábra 3: A közösségi részvétel hat alapelve}

Forrás: Bradely (2011), p 1.

A cégekkel szemben alapvető követelmény, hogy a korábbi, jellemzően befelé forduló szemléletmódot közösségi szemléletmód váltsa fel. A vállalatnak egy alapvető kérdést kell mérlegelnie: saját hálózati infrastruktúrát építsen (például saját szerverein üzemeltetett blog, közösségi hálózat, stb), vagy már meglevő közösségek életében vegyen részt? Hunt (2009) a web 2.0 alkalmazások azon dimenzióját emeli ki, miszerint a résztvevők (fogyasztók) rendszerint érdeklődési körüknek megfelelő csoportokba rendeződnek. Ez a cégek számára kényelmes elérést biztosíthat, amennyiben a vállalat megfelelö eszközökkel, üzenettel és nyelvezettel száll be az itt folyó kommunikációba.

A közösségi média egyik alaptézis, hogy az emberek szeretnek tartalmat létrehozni és megosztani, ám ahhoz, hogy a vállalat vonzza a felhasználói tartalmakat, ahhoz 31 
a cégnek olyan világosan definiált célokat kell lefektetnie a közösségi média jelenlétéhez, mellyel a célcsoport azonosulni tud. Hamilton et al. (2016) kutatása szerint azok a vállalatok lehetnek képesek online (közösségi média) környezetben fogyasztói elköteleződést kialakítani, amelyek „ellenállhatatlan” tartalmakat osztanak meg - máskülönben a céges kezdeményezések közönnyel, elutasítással találkozhatnak. A szerzők szerint az igazán vonzó céges tartalmak is képesek lehetnek „flow-éleményt” biztosítani a fogyasztóknak.

A témában folyó kutatások közösségi média vállalati felhasználási területeit tárták fel, melyet a lenti táblázatban foglalok össze. A kutatásom a közösségi média által indukált szervezeti változásokra fókuszál, ezzel összhangban azt is bemutatom, hogy a marketing osztály mellett a vállalat mely egyéb belső (osztály) illetve külső érintettjeit (partner cégeket) vonhatja be illetve mely érintettekkel alakíthatja át a korábban fennálló kapcsolati hálót (ökoszisztémát - 1d. később)a marketing folyamatok változása az adott területen a cég/marketing osztály:

\begin{tabular}{|l|l|l|l|}
\hline Terület & Hivatkozás & Belső érintett & Külső érintett \\
\hline Stratégiaalkotás & $\begin{array}{l}\text { Montalvo (2016), } \\
\text { Keegan - Rowley } \\
(2017)\end{array}$ & Felső vezetés & Tanácsadó \\
\hline Márkázás & $\begin{array}{l}\text { Kim-Ko (2012), } \\
\text { Dahl (2018), } \\
\text { Montalvo (2016), } \\
\text { Bruhn et al. (2012) }\end{array}$ & Marketing, Sales & $\begin{array}{l}\text { Reklám ügynökség, új } \\
\text { típusú közösségi média } \\
\text { ügynökségek }\end{array}$ \\
\hline Reklám & $\begin{array}{l}\text { Dahl (2018), Bruhn } \\
\text { et al. (2012), Tuten } \\
(2008)\end{array}$ & Marketing & $\begin{array}{l}\text { Kreatív ügynökség, } \\
\text { ATL-BTL ügynökség, } \\
\text { médiavásárló } \\
\text { ügynökség, online } \\
\text { ügynökség }\end{array}$ \\
\hline
\end{tabular}




\begin{tabular}{|c|c|c|c|}
\hline Terület & Hivatkozás & Belső érintett & Külső érintett \\
\hline Mérés & $\begin{array}{l}\text { Kumar et al. } \\
(2016), \text { Montalvo } \\
(2016), \quad \text { Stephen- } \\
\text { Galak (2012), Dahl } \\
\text { (2018), Colicev et } \\
\text { al., (2018) }\end{array}$ & $\begin{array}{l}\text { IT osztály, piac } \\
\text { monitoring és } \\
\text { adatelemző } \\
\text { osztály, }\end{array}$ & $\begin{array}{l}\text { Piackutató, } \\
\text { adatbányász, adatbróker }\end{array}$ \\
\hline $\begin{array}{l}\text { PR, reputáció } \\
\text { menedzsment }\end{array}$ & $\begin{array}{l}\text { Etter et al. (2013), } \\
\text { Aula (2010), Aula } \\
\text { et al. (2010) }\end{array}$ & $\begin{array}{l}\text { PR osztály, sajtó } \\
\text { kapcsolatok, } \\
\text { kommunikációs } \\
\text { osztály }\end{array}$ & $\begin{array}{l}\text { PR ügynökség, } \\
\text { hagyományos sajtó és } \\
\text { médiumok }\end{array}$ \\
\hline HR & $\begin{array}{l}\text { Kaplan-Haenlein } \\
(2010) \text {, Bolton et } \\
\text { al. (2013) }\end{array}$ & HR osztály & $\begin{array}{l}\text { Recruiting/HR } \\
\text { ügynökség }\end{array}$ \\
\hline $\begin{array}{l}\text { Vevő } \\
\text { kapcsolatok }\end{array}$ & $\begin{array}{l}\text { Dong-Wu (2015) } \\
\text { Kim-Ko (2012), } \\
\text { Agnihotri et al., } \\
(2016), \\
\text { Kowalkowski et al., } \\
(2012), \quad \text { Montalvo } \\
(2016), \quad \text { Trainor } \\
(2012)\end{array}$ & $\begin{array}{l}\text { CSR, termelés } \\
\text { („co-creation”) }\end{array}$ & Tanácsadó \\
\hline Jog & Dahl (2018) & Jogi osztály & $\begin{array}{l}\text { Jogtanácsos, ügyvédi } \\
\text { iroda }\end{array}$ \\
\hline
\end{tabular}

Táblázat 7: A közösségi média vállalati felhasználási területei

Forrás: saját szerkesztés

A következökben a fenti táblázat néhány fontosabb sorát érintő, jelentősebb kutatások eredményeit fogom bemutatni.

\section{Stratégiaalkotás}

A stratégiaalkotás folyamatát, valamint a közösségi média és a stratégia alkotás kapcsolatát a dolgozat következő nagyobb fejezete részleteiben is tárgyalja. Itt 33 
röviden utalnék rá, hogy a korábbi kutatások alapján a közösségi média alkalmas a kettős képesség támogatására, azaz a jelen kihívásait felismerni és a jövő építeni is (Montalvo, 2016). Ahogyan a fenti táblázat is utal rá, Keegan-Rowley (2017) amellett érvel, hogy a közösségi média a vállalat-ügynökségek kapcsolatát is átalakítja. A cégek mind több specialistát alkalmaznak, a kutatásuk feltárta, hogy a döntéshozatal minőségét javítja, ha a külső tanácsadókat vonnak be a stratégiaalkotás és az operatív müködés folyamatában is.

\section{Reputáció menedzsment}

A közösségi média jelenlét egyik fontos motivációja és haszna a vállalat számára a reputáció menedzsment lehet. Etter et al. (2013) a hagyományos, valamint a közösségi médián belüli reputáció különálló kezelését javasolta, ez utóbbira saját mérőszámrendszert alkotva, mely kutatásaik szerint alkalmas arra, hogy a vállalati müködés érintettjeinek autonóm értékelését megragadja. Aula (2010) már a kockázatkezeléssel hozza kapcsolatba a web 2.0-át. „A stratégiai reputáció menedzsment szempontjából döntö fontosságú, hogy a közösségi médiát nem lehet kontrollálni, a tartalmat pedig nem lehet a konvencionális médiához hasonló eszközökkel menedzselni. A gyakorlatban ez azt jelenti, hogy a szervezeteknek közel lehetetlen feladatot jelent, hogy a róluk szóló diskurzust az irányításuk alá vonják” - írja a szerző (Aula, 2010, pp. 44).

A vállalati reputációhoz kapcsolódó aktorok, azok lehetséges szerepe a web 2.0-án az alábbi táblázatban foglalható össze:

\begin{tabular}{|l|l|l|}
\hline Aktor & Szerep(ek) & Színtér \\
\hline Egyéni & $\begin{array}{l}\text { befolyásoló } \\
\text { nyomásgyakorló }\end{array}$ & közösségi média \\
\hline Közösség & $\begin{array}{l}\text { befolyásoló } \\
\text { nyomásgyakorló }\end{array}$ & közösségi hálózatok \\
\hline $\begin{array}{l}\text { Egyének csoportja } \\
\text { "netes közeg” }\end{array}$ & $\begin{array}{l}\text { információ-kereső } \\
\text { nyomásgyakorló }\end{array}$ & $\begin{array}{l}\text { közösségi média } \\
\text { online média } \\
\text { weboldalak }\end{array}$ \\
\hline
\end{tabular}




\begin{tabular}{|c|c|c|}
\hline Aktor & Szerep(ek) & Színtér \\
\hline Szervezet & $\begin{array}{l}\text { Javító } \\
\text { Kommunikátor } \\
\text { Befolyásoló } \\
\text { Felügyelő }\end{array}$ & $\begin{array}{l}\text { közösségi média } \\
\text { online média } \\
\text { weboldalak }\end{array}$ \\
\hline Média & $\begin{array}{l}\text { Közvetítő } \\
\text { Felügyelö }\end{array}$ & $\begin{array}{l}\text { hagyományos média } \\
\text { online média }\end{array}$ \\
\hline
\end{tabular}

Táblázat 8: Aktorok, szerepek a reputációval kapcsolatban a közösségi médiában

Forrás: Aula et al., (2018) alapján saját szerkesztés

Eccles és szerzőtársai (2007) a reputációs veszélyforrások három csoportját határozták meg:

1. A vállalati müködés érintettjei nem valós feltételezésekkel élnek a szervezetet illetően

2. A fogyasztói elvárások megváltoznak

3. A szervezet belső okoknál fogva képtelen reagálni a környezet változásaira (például azért, mert egy reputációs kockázat semlegesítésével kapcsolatos döntést eltérő üzleti egységeknél hoznak meg).

Aula et al. (2010) szerint digitális környezetben a fenti lista még legalább két további elemmel kiegészül:

4. a különböző közönségek a szervezeti viselkedéstől eltérő reputációs narrativát fogalmaznak meg

5. a közönség várakozásai és hiedelmei digitális diskurzusokban alakul, a szervezet pedig nem tud eleget tenni ezeknek az elvárásoknak.

Az elmúlt években a közösségi média egy sor látványos PR-katasztrófa helyszíne volt nagyvállalatok számára. Ezek egy része konkrét és dollár százmilliókban mérhető pénzügyi károkat is okozott az egyes cégeknek. A United Airlines 
részvényei például 10 százalékot zuhantak ${ }^{5}$, miután a vállalat ügyfélszolgálata képtelen volt megfelelően kezelni egy, a poggyász kezelés során összetört gitár sorsát. Annak tulajdonosa - egy addig csak közepesen ismert country zenész elsöprő sikerű dalban örökítette meg hánykolódásait. Több nagy ruházati cég (pl. H\&M, Ambercrombie\&Fitch) azt követően kényszerült magyarázkodni, hogy kiderült: az eladhatatlannak bizonyult készleteiket inkább megsemmisítik, minthogy jótékony célokra ajánlanák fel.

Egy saját korábbi kutatásom (Hubert, 2018) eredményei arra engednek következtetni, hogy a közösségi médiában a vállalat-fogyasztó kapcsolatában az önfeltárásnak ugyanolyan szabad és önkéntes módon kell megjelennie, mint az tapasztalható a személyközi kapcsolatokban. Ez más, korábbi kutatások eredményeivel is összhangban a vállalati müködés transzparenciáját emeli ki, mint a közösségi média egyik elvárt alapnormája (pl. Weinberg, 2009).

\section{Márkaépítés}

Montalvo (2016) olyan közösségi média kampányokat ismertet, melyek (1) a márkaismertségre, valamint (2) a márka reputációra gyakoroltak kimutatható hatást. Kim-Ko (2012) szerint a közösségi médiában folytatott marketing tevékenység a vevői érték mind a három, Lemon et al. (2001) kutatásaiban feltárt dimenziójára szignifikáns hatást gyakorol:

\footnotetext{
${ }^{5}$ Did $\quad$ Dave $\quad$ Carroll lose United Airlines $\$ 180 \mathrm{~m}$ ? http://www.economist.com/blogs/gulliver/2009/07/did_dave_carroll_cost_united_1
} 


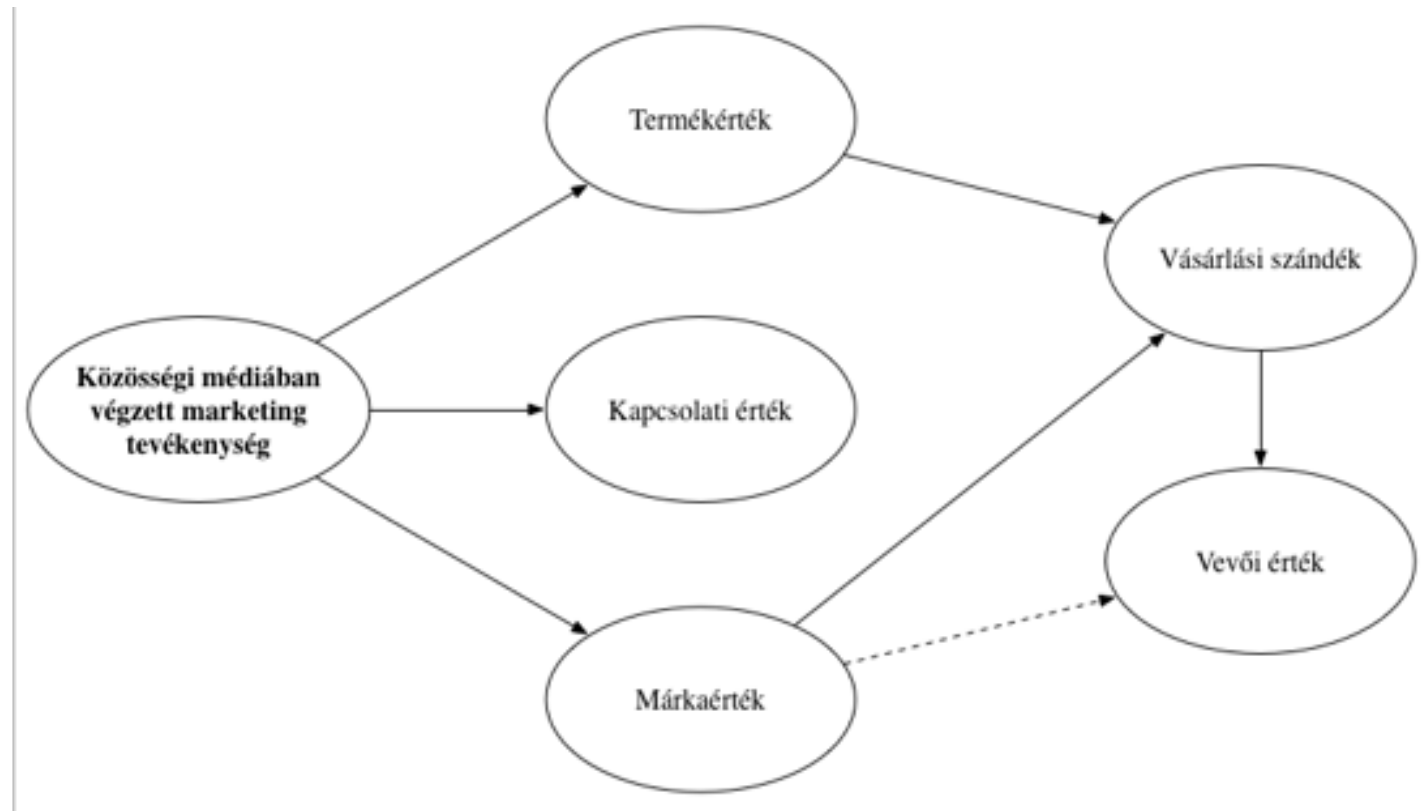

\section{Ábra 4: A közösségi médiában végzett marketing tevékenység hatásai a vevői értékre}

Forrás: Kim-Ko, 2012, pp 1485

A szerzők megállapították: a közösségi médiában végzett marketingtevékenység a vevői érték mind három feltételezett driverére szignifikáns hatással bír, és a befolyásolás szintje jelentős. A korábbi tanulmányokkal ellentétben a szerzők a luxusjavak piacán nem tártak föl közvetlen és jelentős kapcsolatot a vevői érték három drivere és maga a vevői érték közt, sőt, a márkaérték gyengén szignifikáns, közepesen erős negatív kapcsolatot mutatott. A kapcsolati érték kivételével a másik két tényező viszont jelentős pozitív hatást mutatott a vásárlási szándékra.

Bruhn et al. (2012) egy kiterjesztett modellben a hagyományos és új generációs médiumok hatását vizsgálta a vásárlási szándékra a márka közvetítő hatása mellett. Korábbi kutatások (ld. Dellarocas, 2003) alapján egymástól elkülönülten kezelték a fogyasztók egymás közötti diskurzusát (UGC, ewom) és a vállalat által előállított tartalmakat a közösségi médiában. 


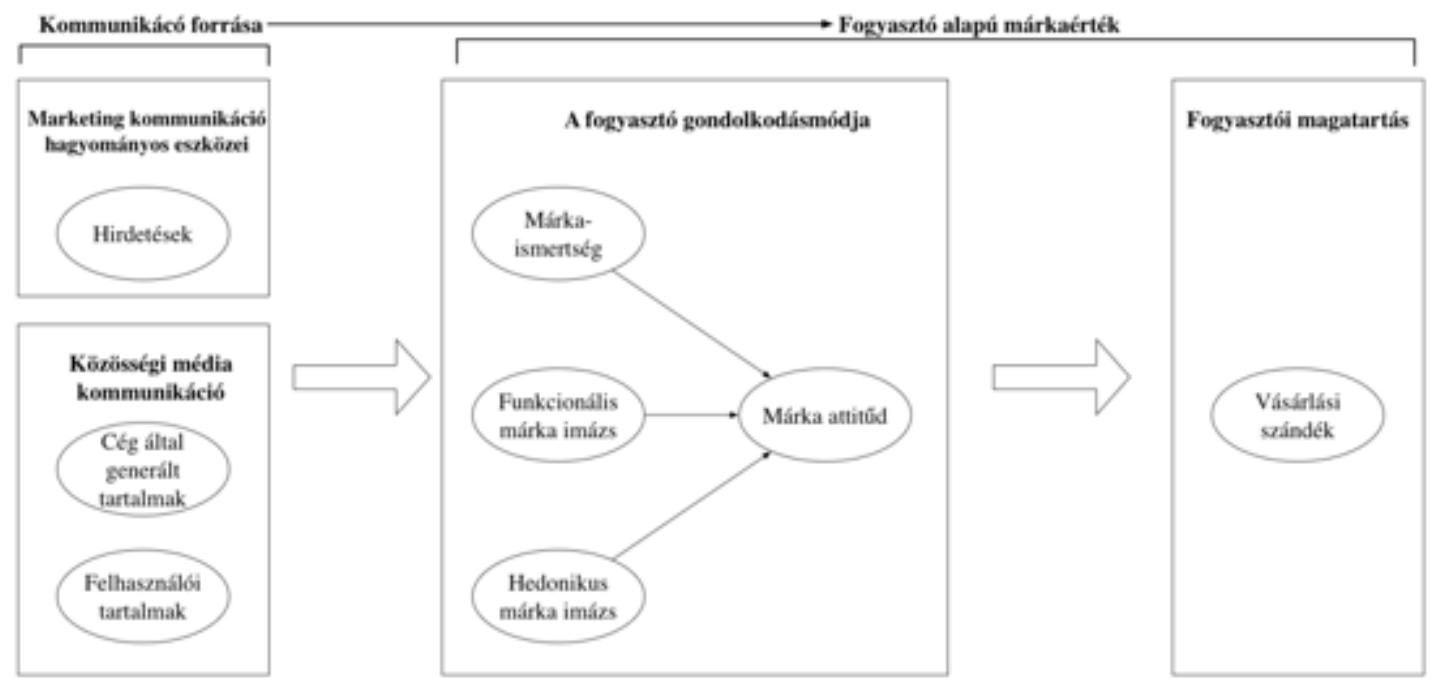

Ábra 5: Hagyományos marketing kommunikáció és a közösségi média kommunikáció hatása a vásárlási szándékra

Forrás: Bruhn et al., 2012 pp 774.

A kutatás alapján a szerzők amellett érvelnek, hogy a vállalatoknak a kommunikációs mixük szerves részévé kell tenniük a közösségi média jelenlétet, világosan meghatározott, stratégiai célok mentén. A közösségi média egyik fontos előnyeként a hagyományos médiához mért relatív költségelőnyt emelik ki, emellett kiemelik, hogy a trendek abba az irányba mutatnak, hogy a fogyasztók bövülö tömege fog egyre több idöt tölteni itt - ami szintén a vállalati felhasználás megkerülhetetlenségét támasztja alá. Ugyanezt támasztja alá Hamilton et al. (2016): a márkák számára a közösségi média nem csak hatékony felületet biztosít az egyéb médián már csak nehezen elérhető fiatalok megszólítására, de itt egyúttal olyan közegben mozognak, ahol azok az emberek (barátok, ismerősök) formálják a véleményüket, akik egyébként is kiemelkedő hatással vannak erre a célcsoportra.

\section{Vevőkapcsolatok és közös értékalkotás}

Hamilton et al. (2016) modelljében a közösségi média tevékenység a vevői értéket növelheti, mivel a vállalat-vevő kapcsolatban magasabb elégedettségi szintet és az interakcióban való „elmerülést” teszi lehetővé. Más kutatások közös értékalkotás (co-creation) folyamatában látják a vevőkapcsolatok elmélyítésének a lehetőségét a közösségi médiában. (Ez egy közös probléma megoldó folyamatra utal, melyben az eladó, vásárló és egyéb aktorok közösen vesznek részt az értéklánc tervezési, 38 
gyártási, szállítási és/vagy vásárlási fázisaiban.) Marketing szakirodalomban a közös értékalkotás fogalmában a vevő kitüntetett figyelemhez jut, mivel a hagyományos értéklánccal ellentétben (ahol az eladónak jut domináns szerep) az együttes értékalkotásban a vevő szerepe messze túlmutat az értékek egyszerü átvételén (ld. Grönroos, 1994). A fogalom nem új, a kutatókat és gyakorló szakembereket már jóval a közösségi média, sőt, az internet megjelenése előtt foglalkoztatta a vállalatok-vevők közös értékalkotása. Gilmor-Pine (1996) a termelés testreszabásának négy szintjét állapította meg:

1. Együttmüködő: interaktív párbeszéd a vevővel, melynek során annak egyedi igényeit is azonosítja a vállalat, a termelés során pedig ennek figyelembe vételével készül el a termék

2. Adaptív: A termék egy vagy több változtatható attribútummal bír, amelyet a vevő utólag módosít saját ízlése szerint (pl. mobiltelefon háttere)

3. Kozmetikázó: minden vevő ugyanazt a terméket kapja, csupán azok csomagolása az eltérő

4. Transzparens: a vevő nem tudja, hogy más terméket kap, mint a többiek

Ebben a felsorolásban ko-kreáció kizárólag az első szinten valósul meg.

Payne et al. (2008) szerint a vevőknél található információ mennyiség, azok tudása és képességei azok az operáns erőforrások, melyeket a vállalat a folyamat során kiaknázhat. A szerzők tanulmányukban kiemelik, hogy a sikeres folyamat egyik kulcsa, hogy a vállalat világos, átlátható forgatókönyveket tár a fogyasztók elé a ko-kreáció folyamatáról, valamint azt is, hogy a különböző fogyasztói szegmentumok eltérő tanulási képességeit és -hajlandóságát is figyelembe kell venni a tervezés során.

Az internet, és különösen a közösségi média terjedésével a közös értékalkotás lehetősége előtt új távlatok nyíltak meg. Holloman (2012) alapján a felhasználók ezeken a fórumokon tipikusan az alábbi tevékenységekben vesznek részt, illetve kezdeményeznek:

- termékfejlesztési ötleteket fogalmaznak meg 
- termékekkel kapcsolatos ismereteket osztanak meg

- segítik egymást problémáik megoldásában

Röndell-Sörhammar (2010) amellett érvel, hogy a digitális forradalom támogatja az eltolódást a szolgáltatás-domináns logika irányába, a fogyasztók ugyanis a korábbinál egyszerübben kapcsolódhatnak be a kereskedelem egyes fázisaiba. A szerzök szerint a közösségi média révén a vállalatok és fogyasztók közt eredeti, őszinte, természetes párbeszéd alakulhat ki, melynek megragadására és kiértékelésére is lehetőséget biztosít az azt müködtető technikai apparátus.

Trainor (2012) szerint a közösségi média olyan eszköz a vállalatok kezében, melynek segítségével azok hosszú távú kapcsolatot tudnak kialakítani és fenntartani a vásárlóikkal. Ebben a kapcsolatban a szerző szerint beleértendő egyfajta közösségi „,vevőszolgálat” (azaz amikor a vásárlók egymást segítik problémáik megoldásában), és az innovációt támogató ko-kreáció. A közösségi hálózatok révén a vállalati teljesítmény fokozható, az arra jellemző interaktivitás és fogyasztói involvement révén megvalósítható az együttes vállalati-vevő értékteremtés.

\section{Kritikai elemzés, összefoglalás}

A fejezet elején a közösségi média marketing egymillió dolláros kérdése szerepelt: milyen módon tudnak a vállalatok értéket teremteni a közösségi módja használatával. Láttuk, hogy a technológiai lehetőségek puszta használata nem elegendő, ezek bárki számára könnyen hozzáférhető, egyszerüen használható applikációk, melyek puszta használata önmagában nem alkalmas arra, hogy az fenntartható versenyelőny forrássá legyen. Ahhoz, hogy a vállalat akár stratégiai szinten is támaszkodni tudjon a közösségi médiára, ahhoz átgondolt, a stratégiához illeszkedő (marketing) döntések meghozatalára van szükség, melyeknek komoly szervezeti következményei lehetnek (ld 9. táblázat). Ehhez fontos látni, hogy a fogyasztó szerepe milyen módon alakult át a hagyományos és az új média esetében:

\begin{tabular}{|l|l|lll|}
\hline & Hagyományos média & Új média & & \\
\hline Fogyasztó & Ellenáll az üzenetnek & $\begin{array}{l}\text { Aktív részese az üzenet } \\
\text { előállításának }\end{array}$ & \\
\hline
\end{tabular}




\begin{tabular}{|c|c|c|}
\hline & Hagyományos média & Új média \\
\hline $\begin{array}{l}\text { Üzenet } \\
\text { kibocsátója }\end{array}$ & Vállalat & $\begin{array}{l}\text { Vállalat, fogyasztó vagy egyéb (pl. } \\
\text { sajtó, fogyasztóvédelmi csoportok, } \\
\text { stb) }\end{array}$ \\
\hline Vállalati kontroll & (Közel) teljes & $\begin{array}{l}\text { Minimális/nincs. Kontroll helyett: } \\
\text { folyamat menedzsment }\end{array}$ \\
\hline Jellemző médium & $\begin{array}{l}\text { Televízió, rádió, újság, } \\
\text { magazin, hagyományos } \\
\text { weboldalak, stb. }\end{array}$ & $\begin{array}{l}\text { Közösségi média: } \\
\text { közösségi hálózatok, } \\
\text { megosztó portálok, stb. }\end{array}$ \\
\hline $\begin{array}{l}\text { Fogyasztó attitüd } \\
\text { a jellemző médium } \\
\text { irányában }\end{array}$ & $\begin{array}{l}\text { Stagnáló érdeklődés } \\
\text { illetve elfordulás }\end{array}$ & Növekvő érdeklődés \\
\hline
\end{tabular}

Táblázat 9: A fogyasztó szerepe a hagyományos és az új média esetében

Forrás: saját szerkesztés

Az első megállapítás mindezek kapcsán az, hogy miként a felhasználók, úgy a cégek számára is a közösségi média az önkitárulkozás valamint az önbemutatás fóruma lehet. A cég itt a fogyasztó-vállalat közt fennálló egyfajta információs asszimetriából profitálhat, és saját „fronstage” folyamatait képes lehet „észlelt backstage"-ként tálalni - ami a fogyasztók szemében a vállalat hitelességét növeli, és a feltárt információkat is izgalmasabbá, érdekesebb - ezáltal vonzóbbá teheti a fogyasztók felé.

Megvizsgáltuk, hogy milyen formában lehet alkalmas a közösségi média az érték teremtésére és megragadására (akár fenntartható versenyelőny formájában, akár más féle módokon). Számos olyan vállalati és marketing területet bemutattam, ahol a közösségi média alkalmazása: reputáció menedzsment, márkaérték és annak növelése, ko-kreációs alkalmazások becsatornázása a vállalat-fogyasztó viszonyba, engagement valamint azok a fogyasztói belátások (insights), melyektől a cég a közösségi média használata nélkül eleshetne.

Érdekes kérdés lehet közösségi média marketing tevékenység megtérülésének a vizsgálata - a témával foglalkozó kutatók állítása szerint a $\mathrm{RO}(\mathrm{M}) \mathrm{I}$ vizsgálata koránt sem magától értetődő. Hoffman-Fodor (2010) alapján ott megjelenő 41 
tartalmak „viralitás faktora” miatt nem is mindig hasonlítható a korábbi marketingtevékenységek esetében mért ROI-hoz.

Kutatásom fő fókusza ugyanakkor a szervezeti konzekvenciákra esik, melyet csupán rövidebben érintettem az eddigi áttekintésben. A cégek belső szervezeti hierarchiájában új pozíciók jelentek meg (Murthy-Lewis, 2015), a közösségi média belső felhasználása révén pedig a szervezet innovatívabbá válhat és a tacit tudás átadásában is előnyösen mozdíthatja el a folyamatokat.

\section{Szervezet elmélet}

\subsection{Szervezeti konfiguráció - szervezeti teljesítmény - stratégia}

Szervezetelméleti kutatások az elmúlt évtizedekben alaposan, változatos dimenziók mentén vizsgálták meg a szervezetek felépítésének kapcsolatát olyan, a vállalatok számára kulcs fontosságú változókkal, minta teljesítmény, stratégiaalkotás, hatékonyság, hatásosság, stb. Ebben a fejezetben elöször egy rövid áttekintést adok ennek a kutatási területnek a kialakulásától a '90-es évekig tartó első időszakáról. Az irodalom bősége miatt könnyü lenne elveszni ezeknek a mára már klasszikusnak számító mủveknek az elemzésében, ugyanakkor nem téveszthető szem elől, hogy a XX. század vége valamint a XXI. század első évtizedeiben megindult digitális forradalom, a számítástechnika, mobileszközök, internet majd a közösségi hálózatok megjelenése a szervezetek életében is gyökeres fordulatot eredményezett. Éppen ezért a -nevezzük így- „,klasszikus” iskola műveit pusztán olyan mélységben tárgyalom, ami ahhoz szükséges, hogy arra építkezve a digitalizáció hatásait vizsgáló szakirodalom is világosan kibontható legyen.

Mi az oka annak, hogy egyes vállalkozások teljesítményben felülmúlják társaikat? A szervezetelméleti szakirodalom egy meghatározó irányvonala a szervezet és környezet illeszkedésében keresi erre a kérdésre a választ. Az a vállalat, amely olyan szervezeti felépítést alakít ki, amely megfelel a környezeti kihívásoknak, az összességében sikeresebb, életképesebb lesz versenytársainál. A szakirodalomban 
a két fogalom kapcsolatát a szervezeti konfiguráció több dimenziós konstruktumaival írják le, mint például a szervezeti struktúra, szervezeti kultúra, a termék-piac stratégia vagy a piaci környezet (Yarbrough et al, 2011; Olson et al., 2005; Vorhies-Morgan, 2003).

A stratégia elmélet a környezet - forma - funkció - teljesítmény keretben a kontextus, struktúra, stratégia elemek fontosságára irányítja rá a figyelmet. Ezt a komplex stratégiai irányzatot „konfigurációs elméletnek” nevezzük (Mintzberg et al., 2009):

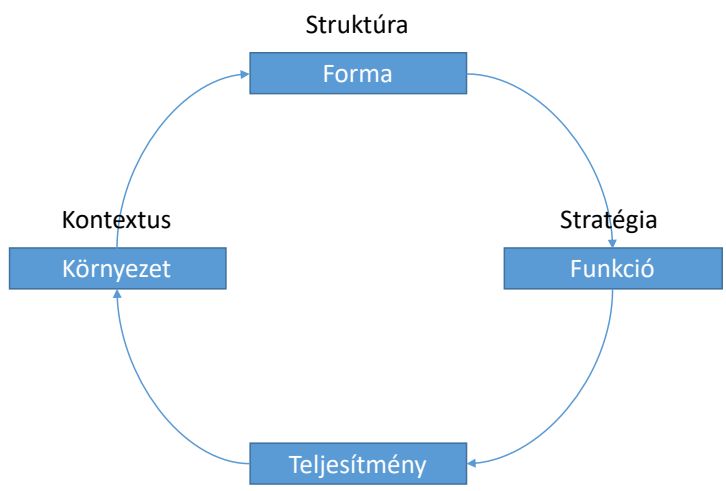

Ábra 6: Mintzbergi konfigurációs elmélet

Forrás: Mintzberg et al., 2009

\section{Szervezeti forma és struktúra}

A marketingszervezetet hagyományosan annak felépítése alapján vizsgálta a szakirodalom:

- a funkcionális marketingszervezetben az általános marketing feladatok ellátását valamint az értékesítést végző szervezeti alegységeket szokás megkülönböztetni

- a divizionális szervezeti felépítés két legjellegzetesebb formája a (1) termékre, termékcsoportokra szerveződő, valamint a (2) földrajzi terület szerint kialakított marketingszervezet 
- a mátrix-szervezetben pedig két szervezetképzési ismérv is megjelenik (Bauer-Berács, 2016)

Antal (2006) a három szervezeti modell alkalmazhatósági feltételeit, valamint azok jellemzőit az alábbi módon foglalja össze:

\begin{tabular}{|c|c|c|c|}
\hline & \multicolumn{3}{|c|}{ A szervezeti struktúra modelljei } \\
\hline & Funkcionális & Divizionális & Mátrix \\
\hline \multirow{2}{*}{$\begin{array}{l}\text { Alkalmazási } \\
\text { feltételek }\end{array}$} & $\begin{array}{l}\text { Homogén, nem túl } \\
\text { komplex } \\
\text { alaptevékenység }\end{array}$ & Diverzifikált tevékenység & $\begin{array}{l}\text { Diverzifikált, komplex, } \\
\text { innovativ tevékenység }\end{array}$ \\
\hline & $\begin{array}{l}\text { Relative stabil, nem túl } \\
\text { komplex kömyezet }\end{array}$ & $\begin{array}{l}\text { Dinamikus, összetett } \\
\text { környezet }\end{array}$ & $\begin{array}{l}\text { Dinamikus, összetett } \\
\text { környezet }\end{array}$ \\
\hline \multirow{4}{*}{$\begin{array}{l}\text { A szervezeti } \\
\text { modell föbb } \\
\text { jellemzöi }\end{array}$} & $\begin{array}{l}\text { Az alaptevékenységet } \\
\text { funkcionálisan } \\
\text { specializált alrendszerek } \\
\text { végzik }\end{array}$ & $\begin{array}{l}\text { Az alaptevékenység } \\
\text { termék-, vevö-, vagy } \\
\text { regionális elven } \\
\text { specializált }\end{array}$ & $\begin{array}{l}\text { Az alaptevékenység } \\
\text { egyszerre két elven } \\
\text { specializált ( } 2 \\
\text { egyenrangú dimenzió) }\end{array}$ \\
\hline & $\begin{array}{l}\text { A stratégiai és operativ } \\
\text { döntéseket a } \\
\text { felsővezetés hozza meg }\end{array}$ & $\begin{array}{l}\text { A felsōvezetés a } \\
\text { stratégiai, a diviziók } \\
\text { vezetoôi pedig az operatív } \\
\text { dỏntéseket hozzák meg }\end{array}$ & $\begin{array}{l}\text { A stratégiaia és az } \\
\text { operatíi döntéseket a két } \\
\text { specializációs elv } \\
\text { szerinti vezetōi szintek } \\
\text { közösen hozzák meg }\end{array}$ \\
\hline & $\begin{array}{l}\text { A szervezet müködése } \\
\text { (a feladatok és } \\
\text { hatáskörök) részleteiben } \\
\text { is szabályozott }\end{array}$ & $\begin{array}{l}\text { A diviziók müködésének } \\
\text { keretei szabályozottak }\end{array}$ & $\begin{array}{l}\text { A müködés keretei is } \\
\text { változhatnak, az üzleti } \\
\text { igényeknek megfelelōen } \\
\text { a vezetők } \\
\text { alkalmazkodnak egy } \\
\text { adott helyzethez }\end{array}$ \\
\hline & $\begin{array}{l}\text { A funkcionálisan } \\
\text { specializált alrendszerek } \\
\text { belsõ struktúrája eltérō } \\
\text { módon alakitható ki }\end{array}$ & $\begin{array}{l}\text { A divíziók belsō } \\
\text { struktúrája eltéroo módon } \\
\text { alakithatóak ki, de } \\
\text { többnyire funkcionális } \\
\text { elven specializáltak }\end{array}$ & $\begin{array}{l}\text { A mátrix egyes } \\
\text { dimenzión belül eltérō } \\
\text { belsō struktúrák } \\
\text { alakíthatóak ki }\end{array}$ \\
\hline
\end{tabular}

\section{Ábra 7: A szervezeti modellek jellemzői és alkalmazási feltételei} Forrás: Antal (2006), pp8.

Fontos leszögezni, hogy a fenti táblázat nem tartalmaz értékítéletet (nem jelenthető ki például az, hogy a mátrix szervezett ,jobb” a funkcionális szervezetnél), ami összhangban van a kontingenciaelmélet egyik legalapvetőbb megállapításával: nincs egyetlen üdvözítő út. A szervezet müködését a müködési környezethez kell igazítani (- ez már évtizedek óta ismert ld pl. Burns-Stalker, 1961; Lawrence- 
Lorsch, 1969; stb). Érdemes még kiemelni a környezeti változásokhoz történő adaptációt, melyben defenzív, offenzív illetve proaktív stratégiát követhet a szervezet.

Az illeszkedést értelmezhető külső és belső szinten is: előbbi a struktúra valamint a vállalati adottságok, stratégiai célkitűzések kapcsolatát vizsgálja (megfelelő a szervezeti struktúra?) - utóbbi a szervezeti működés belső logikáját vizsgálja (szervezeti struktúra konzisztenciája) (Antal, 2006).

A modern marketing szervezetben a feladat- és hatáskörök kiterjedését tapasztaljuk, ami a szervezeti komplexitás és ezzel párhuzamosan a koordinációs feladatok bővülését hozta magával. Habár az üzleti stratégia, környezeti kihívások, jogszabályi környezet, valamint egyéb megfontolások alapján a vállalatok (és a marketing osztályok) eltérő szervezeti formát öltenek, ezeket Olson et al., 2005 szakirodalmi áttekintése alapján az alábbi dimenziókkal írhatjuk le:

- formalizáció - vagyis a szabályok, folyamatok, döntési mechanizmusok és munkakapcsolatok formalizált leírásának szintje

- centralizáció - vagyis a felsővezetés által kézben tartott hatalom szintje illetve annak delegálása a közép és alsóbb szinten dolgozó menedzserek számára

- specializáció-vagyis a feladatok és tevékenységek felosztásának szintjét, valamint a munkavállalói kontroll szintje ezen feladatok végrehajtásának megválasztásában.

\section{Teljesítmény}

A (marketing) szervezeti struktúráját a szakirodalomban változatosterületekkel és kulcsfogalmakkal hozták kapcsolatba, köztük például az eredményességgel (Olson et al., 2005). Vorhies-Morgan (2003) az üzleti stratégia és a marketing szervezet struktúrájának illeszkedésével magyarázta a cégek teljesítményét.

A szervezetelméleti valamint stratégiai menedzsmenttel foglalkozó kutatók a teljesítménnyel kapcsolatos kérdéseket konfiguráció elméleti alapokon közelítik meg, ahol a konfiguráció a vállalkozások stratégiai és szervezeti jellemvonásainak 45 
több dimenzió mentén leírható együtt állását jelenti. A konfigurációs elmélet alapvetése, hogy minden stratégiai megközelítéshez hozzárendelhető egy olyan ideális szervezeti konstelláció, ami kiemelkedő üzleti teljesítményt eredményez.

A stratégia típusa arra a szervezet által tervezett mintára utal, amellyel a cég saját stratégiai célját kívánja megvalósítani (a szerzők a Miles-Snow, 1978-as klasszikus munkában megjelenő négy stratégiai lehetőség közül a világos stratégiai irányvonallal rendelkező három archetípust emeltek át):

- kutató: proaktív hozzáállás jellemző, a változásokat nem csak figyelik, de sok esetben maguk hozzák azokat létre.

- védekező: stabil piaci szegmensben hosszú távú kiszolgálásra törekszenek, jellemzően szűk termékkínálattal és standardizált gyártási folyamatokkal

- elemző: gyakorlatilag a kutató és a védekező, mint két végpont közötti kontinuum közbenső részén helyezkedik el, amely mindkét „világ” erősségeinek kiaknázására törekszik: egyszerre kívánják szavatolni a költséghatékonyságot valamint innovatív megoldásokkal piac- és/vagy termékfejlesztést végrehajtani (Csepeti, 2010)

A marketing szervezet (1) a struktúrában (=feladatok valamint a döntéshozói hatalom szerveződése) valamint (2) a feladatokban (=marketing feladatok vállalása és végrehajtása) ragadható meg. A „funkcionalista marketing szervezet” típusú megközelítésnek azonban elmúlt években mind többen kérdőjelezik meg a létjogosultságát, a szakirodalomban a marketing „filozófia” és az ezzel összefüggésben felmerülö tevékenységek, feladatok „funkciók közötti szétosztásról” számolnak be, melyekben ,a hagyományos marketing szervezeten túl egyéb funkcionális csoportok is részt vesznek" (Hult, 2011, p.509). (Maga a koncepció nem újkeletű, Keith már bő félévszázada olyan marketing vállalatokról írt, ahol a marketing az egész szervezetet ,átitatja” - Keith, 1960).

\section{Környezet (kontextus)}

A gyorsan változó, dinamikus környezetben müködő, globális kihívásokkal szembe néző vállalatok, marketing szervezetek miatt a hangsúly a szakirodalomban a 
marketingosztályok formális leírásán túllépve olyan kérdések megválaszolására került át, mint a szervezet kapcsolata a teljesítménnyel, kreativitással, tudás megszerzésével. A marketing ráadásul áttörve a szüken értelmezett osztálykereteket, az egész vállalat szemléletmódjának befolyásolását, irányítását célozza meg, hogy „piac-vezérelt” szervezeteket alakítson ki a hagyományos termelö/szolgáltató vállalatok helyén (Kotler et al., 2008).

Valamennyi akadémiai kutatás egyetért abban, hogy a közösségi média dinamikus, turbulens gazdasági környezetet - és az ezzel együtt járó kihívásokat jelenti a vállalatok számára. Burns-Stalker (1961) - klasszikus - írásához visszanyúlva ennek már önmagában egyértelmü szervezeti konzekvenciái vannak: 

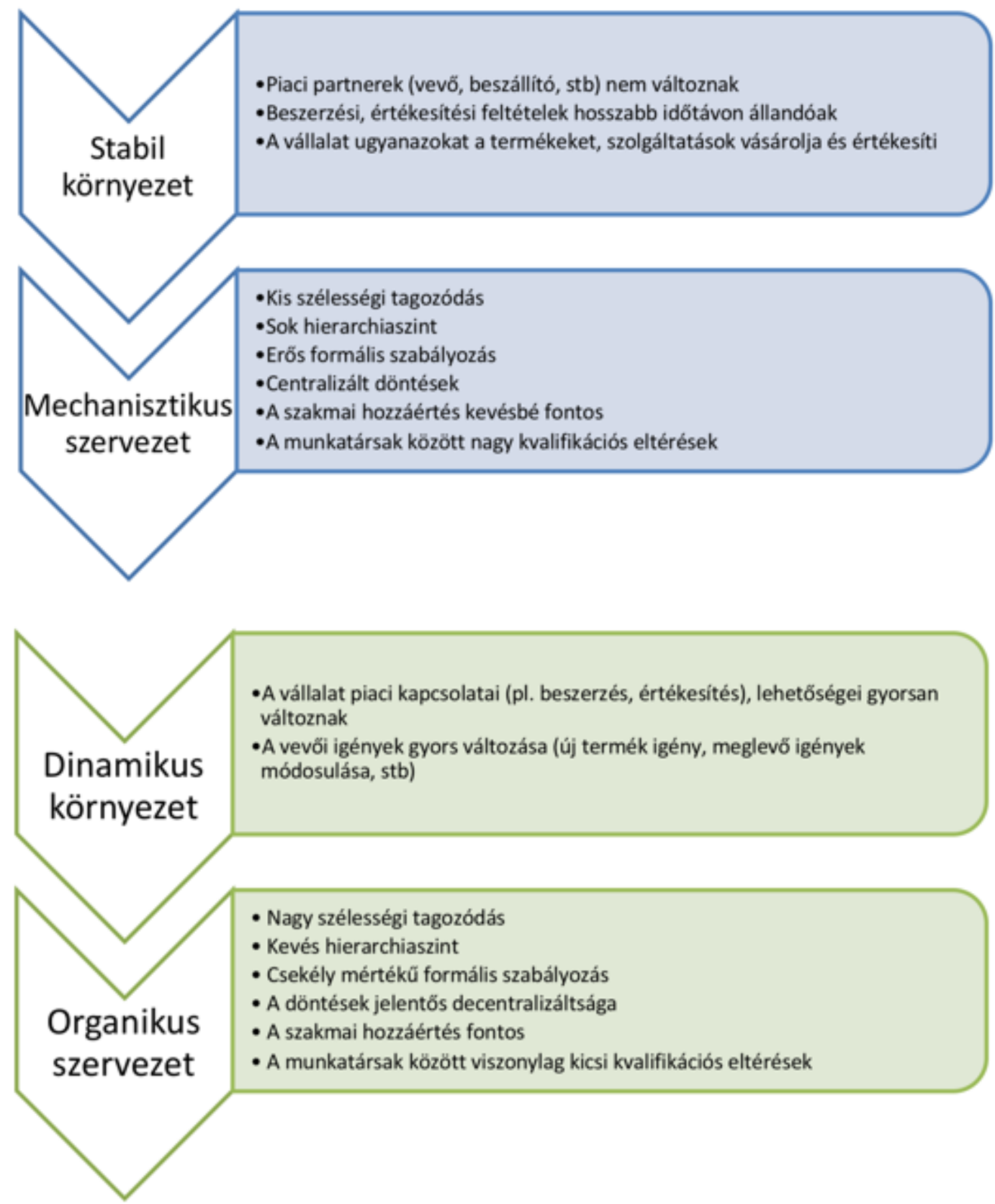

Ábra 8: Stabil és dinamikus környezet szervezeti konzekvenciái

Forrás: Burns-Stalker (1961) alapján saját szerkesztés

Tervezett vs. megvalósult stratégia

Mintzberg et al. (1998) arra is felhívja a figyelmet: a szervezeti forma a stratégiaalkotás és -megvalósítás folyamatával is szoros összefüggést mutat - ezt a kapcsolatot számos kutatás bontotta ki részleteiben. Először röviden vizsgáljuk meg 
az alfejezet címében megjelölt két fogalom, a tervezett és megvalósult (planned/emergent) stratégia közötti összefüggést Mintzberg alapján:

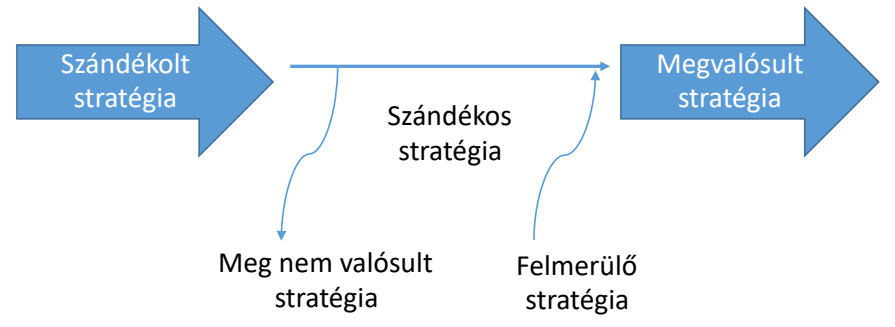

\section{Ábra 9: A stratégia típusai}

Forrás: Mintzberg-Waters (1985), p.258

A szerzők a folyamat alapján eltérő stratégia típusokat vázoltak fel (pl. a tervezettnél a stratégia alapja egy formális terv, a vállalkozói stratégiában egy központi vízió, az ideológiainál a közös hit, stb). A környezet gyakorlatilag mindegyik verziónál központi szerepet játszik, a szándékolt és a megvalósult stratégia közötti különbségek jelentős részben a környezeti kihívásokkal, változásokkal magyarázhatók. Mintzberg (2009) alapján dinamikus környezetben annak kihívásai a szervezet koránál, méreténél és más tényezőknél is sokkal meghatározóbbaknak bizonyulhatnak.

\section{Kritikai összegzés és a továbblépés szükségessége}

A szervezet elmélet - nevezzük így - klasszikus iskolája fontos fogalmakra irányította rá a figyelmet és olyan alapvető összefüggéseket tárt fel, amelyek a kutatók és a gyakorló menedzserek számára is hasznos eszköznek bizonyultak. Az összegzés alapján láthatóvá vált, hogy ezek a müvek a „totálkép” („big picture”) nézőpontjából szemlélik a folyamatokat, ahonnan láthatóvá válnak az összefüggések a szervezet környezete, valamint annak belső folyamatai között. Megérthetjük, hogyan reagálhat egy vállalat a turbulens környezeti feltételekre, miként tud optimális sebességre kapcsolni akkor, amikor a vihar elül, stb.

A tudományok - nem csak a társadalom és menedzsment tudományok - általában küzdenek a mikró- és makró világ közötti kapcsolat megteremtésével. Ami müködik „en gros” az sokszor nem müködik kicsiben és vice versa. A mintzbergi 
modellel pontosan ez a helyzet. A modell egyfajta nagytotál képként írható körül, amely ugyan fontos tanulságokat fogalmazott meg, de a részleteket azonban elfedi.

Ezt a „hagyományos” megközelítést több oldalról érte kritika. A szakirodalomban több kutatás is arra utal, hogy a szervezet és környezet határai nem egyértelmüen meghúzhatóak. A vállalat - vevők - beszállítók elhatárolás helyett hálózatos vagy ökoszisztéma szerü működésről beszélhetünk.

A közösségi média tekinthető környezeti kihívásként, amire a vállalatnak stratégiai választ kell kidolgoznia, de ennél véleményem szerint pontosabb képet ad, ha egy olyan újszerü helyzetnek ábrázoljuk, melyet a cégnek, mint szervezetnek (illetve: mint egyénekből álló csoportnak) „,meg kell tanulnia”.

A tanulás - akár egyéni, akár szervezeti, akár pedig szervezet közötti szinten - az eddig áttekintett modellekből hiányzik. Több jel is mutatja, hogy ez a fogalom a kulcs ahhoz, hogy megértsük, miként tudnak a szervezetek sikerrel reagálni a közösségi média által megváltoztatott viszonyokra. Bár a szakirodalomban kevés cikk foglalkozik közvetlenül a két terület (szervezeti tanulás illetve közösségi média) kapcsolatával, számos jel mutat arra, hogy a kettőnek nagyon is sok köze van egymáshoz:

- Ahogyan azt a közösségi média áttekintésekor láttuk, ezek az applikációk sok szempontból új helyzetet teremtettek a cégekre, melynek megértése, a hatékony reakciók kifejlesztése eltérő meredekségü (és alakú) tanulási görbével jellemezhető

- A közösségi média felbukkanását követően sorra születtek cikkek, melyek ezt a területet tárták fel. A kezdetekben inkább leíró jellegü cikkek néhány év alatt tanácsadó jellegüekké váltak, ami a terület mélyebb megértésére utal (Lamberton-Stephen, 2016)

- Az első évek „lehet-e eladni” típusú kérdései helyére az elmúlt években már a „hogyan lehet (hatékonyabban) eladni” kezdetü kérdések kerültek a szakirodalomban és a gyakorló szférában is. Ez az én értelmezésemben arra utal, hogy a cégek kezdenek beletanulni a közösségi értékesítésbe (és az értékesítés minden vitán felül a marketing egy kiemelt feladata) 
- Lamberton és Stephen a fentebb már idézett cikkében is az internetet, mint eszközt az első általuk vizsgált érában a fogyasztókhoz kötik (2000-2004 között a cégek helyett a felhasználók használják ki aktívan az internet lehetőségeit az általuk vizsgált cikkek szerint), majd ezt követően fokozatosan a cégek kerülnek a fókuszba (az utolsó éra náluk is az értékesítéssel ér véget).

\section{2. Ökoszisztéma, mint vállalati struktúra}

A biológiából kölcsönzött terminológiával élve, a 2000-es évek elejétől mind több szerző a vállalatok kapcsolatát az ökoszisztéma fogalmával írta körül. Így lettek egyes cégek „kulcsfontosságú fajok”, melyek köré szerveződve nagyszámú más „faj” (azaz cég) él, és ennek a laza, de egymással összefonódó érdekkapcsolatnak köszönhetően képes minden szereplö kölcsönösen hatékony lenni és túlélni (IansitiLevien, 2004). Ez a megközelítés lebontja, de legalábbis elmossa a vállalatok közötti határokat. A vállalatok meghatározott mértékig hozzáférnek a másik erőforrásaihoz, a függetlenség helyett a kölcsönös függés, a zéró összegü játék helyett a szimbiózis kerül a fókuszba.

Adner egy lépéssel tovább lépve amellett érvel, hogy az ökoszisztéma nem csak a vállalatközi kapcsolatok, de a vállalati struktúra leírására is alkalmazható. Megfogalmazásában az „ökoszisztéma alapja meghatározott számú, multilaterális partner struktúrájának egymáshoz igazítása egy központi értékajánlat megvalósitása érdekében" (Adner, 2017, p 42). Ennek jellemzője, hogy:

- az ilyen struktúrában a kétoldalú kapcsolatok helyett a multilaterális kapcsolatok alakulnak ki

- meghatározott számú résztvevő van (az ökoszisztéma nem nyílt végü)

- az elemzés fókuszában a központi értékajánlat és nem az egyedi vállalati tevékenység célja áll

A szerző négy fogalommal írja az ökoszisztéma jellegű struktúrát: 
1. tevékenységek, vagyis azok a konkrét tettek, melyeket a hálózat tagjai az értékajánlat érdekében végrehajtanak

2. aktorok: a tevékenységek végrehajtói, akik nem szükségszerüen kapcsolódnak egyetlen központi aktorhoz

3. pozíció: a tevékenységek áramlását írja le, meghatározva, hogy melyik aktor hol helyezkedik át és ki kinek ad át tevékenységeket

4. kapcsolatok, vagyis az aktorok közötti transzferek (pénzügyi, információ, befolyás, stb) leírása

Az ökoszisztéma struktúrát a szakirodalomban különösen sokszor kötik össze a(z):

- high-tech szektorral: West-Wood (2013) például egy korábban népszerü mobil operációsrendszer (Symbian) hanyatlását magyarázta azzal, hogy a központban levő vállalat (Nokia) körül kialakult ökoszisztémát a versenytársak szétrombolták azzal, hogy az alkalmazásfejlesztő partnercégeket saját magukhoz csábították.

- innovációval: Davis (2016) a komplex fejlesztések (pl. MRI berendezések, okostelefonok, stb) mutatott ki multilaterális együttmüködéseket, Adner (2016) azt vizsgálta, hogy az innovációt célzó ökoszisztémákban hogyan alakulnak az erőviszonyok, stb

A közösségi médiára magára is rendszerint hivatkoznak a szakirodalomban ökoszisztémaként (pl. Hanna et al., 2011, Mangold-Faulds, 2009, stb). Ezzel a szerzők rendszerint az alkalmazások közötti kölcsönös függőségre, valamint a közösségi térre utalnak. A szakirodalom áttekintése alapján itt egy irodalmi rés van. Számos jel utal arra, hogy a közösségi média és az újabb technológiák térnyerése a fentebb ismertetett, ökoszisztéma szerü müködés irányába tolták el a marketing osztályok müködését. Erre utal a közeg újszerü volta, az induló speciális profilú ügynökségek szaporodása (pl. kontentgyárak, natív és programmatic hirdetések, adex, stb). A saját kutatásomban ezért ez egy fontos feltárandó témaként szerepel. 


\subsection{A szervezeti tanulás}

A szervezeti tanulás témája mondhatni kurrens és felkapott kutatási terület - erre utal a témában megjelenő akadémiai cikkek, könyvek, menedzseri útmutatók, példatárak sokasága. Ezzel együtt is elmondható az, hogy bár a téma megértése összességében növekedett, a területen még most is jelentős koncepcionáliszürzavar tapasztalható (Tosey et al., 2012). A szervezeti tanulást a tapasztalat függvényeként a szervezet tudásában bekövetkező változásként definiálhatjuk (Argote, 2012). A terület alapjait Chris Argyris és Donald Schön munkássága rakta le. Az ő megközelítésükben egy- illetve kéthurkos tanulási folyamat különböztethető meg: előbbi a visszacsatolás révén a folyamatok minőségi javítását, utóbbi ennél többet, a szervezet müködésének átalakítását jelenti.

A tudás jelenthet explicit formában megfogalmazható (deklaratív) illetve procedurális tudást, valamint képességet és gyakorlatot is. Az ugyanakkor nem eldöntött, hogy ez inkább kognitív vagy magatartási alapú változást jelent-e (Easterby-Smith et al., 2000).

A tanulás egy fontos dimenziója, hogy az időben valósul meg. Különösen fontos szempont ez az új technológiák adaptációjánál, ahol kutatások szerint akár jelentős idő is eltelhet a technológia megjelenése valamint annak szervezeti implementációja közt. Ennek oka lehet a szervezeti paraméterek (pl. felső vezetés) és a technológia inkompatibilitása, a bevezetéshez, alkalmazáshoz szükséges szervezeti képességek vagy személyi kompetencia hiánya, stb. (Choi-Thoeni, 2016). A közösségi média esetében gyakorlatilag valamennyi elképzelhető problémára lehetne példákat citálni.

A szervezeti tanulás képességét Argyris - Schön megközelítésétől gyökeresen eltérő koncepcióban is tárgyalták már kutatók. A tanulás és innovációra való szervezeti képesség holisztikus megközelítésében (Schuchmann-Seufert, 2015) a tanulásra alkalmas vállalatok olyan ambidexter szervezetek, melyek a ma problémáival és a jövő kihívásaival egyidejüleg képesek felvenni a versenyt: a cég egy dinamikus folyamattal jellemezhető képesség révén tud „megtanulni tanulni”, a környezetét felfedezi és a lehetőségeket kiaknázza. 
A szervezet és az egyének viszonyában ez mindkét oldalról követelményeket jelent:

- a munkavállalókkal szemben az élethosszig tartó tanulás követelményként jeleik meg, a napi munkavégzést a rutin helyett (mellett) a reflexiónak kell jellemeznie

- a szervezeteknek pedig biztosítaniuk kell a keretek az innováció működéséhez, implementálásához (Lang-Pätzold, 2004)

Argote (2012) modelljében a szervezeti tanulás kontextus-függő jelenség, ahol a szervezet maga is része a környezetnek, de emellett a versenytársak, vevők, oktatási intézmények, kormányzat, stb is szerepet játszhat abban. A környezeti elemek szempontjából különbséget tehetünk aktív valamint látens elemek között: előbbi cselekvőképes (pl. szervezeti tagok, eszközök), utóbbiak nem.

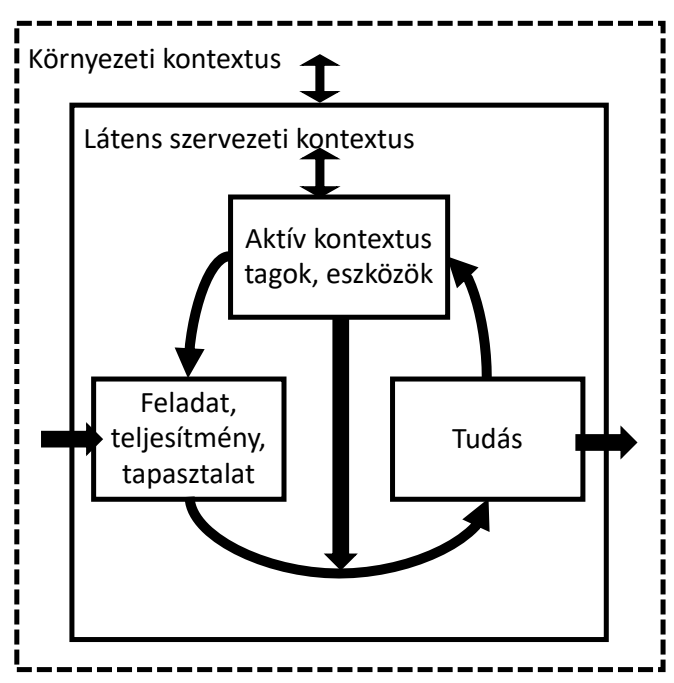

\section{Ábra 10: Szervezeti tanulás modellje}

Forrás: Argote (2012), pp33

A modellben a tanulás egy folyamatosan zajló, ciklikus tevékenység, ahol a szervezeti feladatok, teljesítmény tapasztalat a környezeti tényezők kontextusában a tanulási folyamat révén szervezeti tudássá alakul át. A modellben a környezet szerepe kettős: (1) a tanulási folyamatot befolyásolja, valamint (2) a szervezeti tudás „felszippantásával” befolyásolja a vállalat teljesítményét, feladatait és tapasztalatát. 
Argote a modell 4 tényezőjét emelte ki, melyeket az alábbi aldimenzióik mentén vizsgált meg:

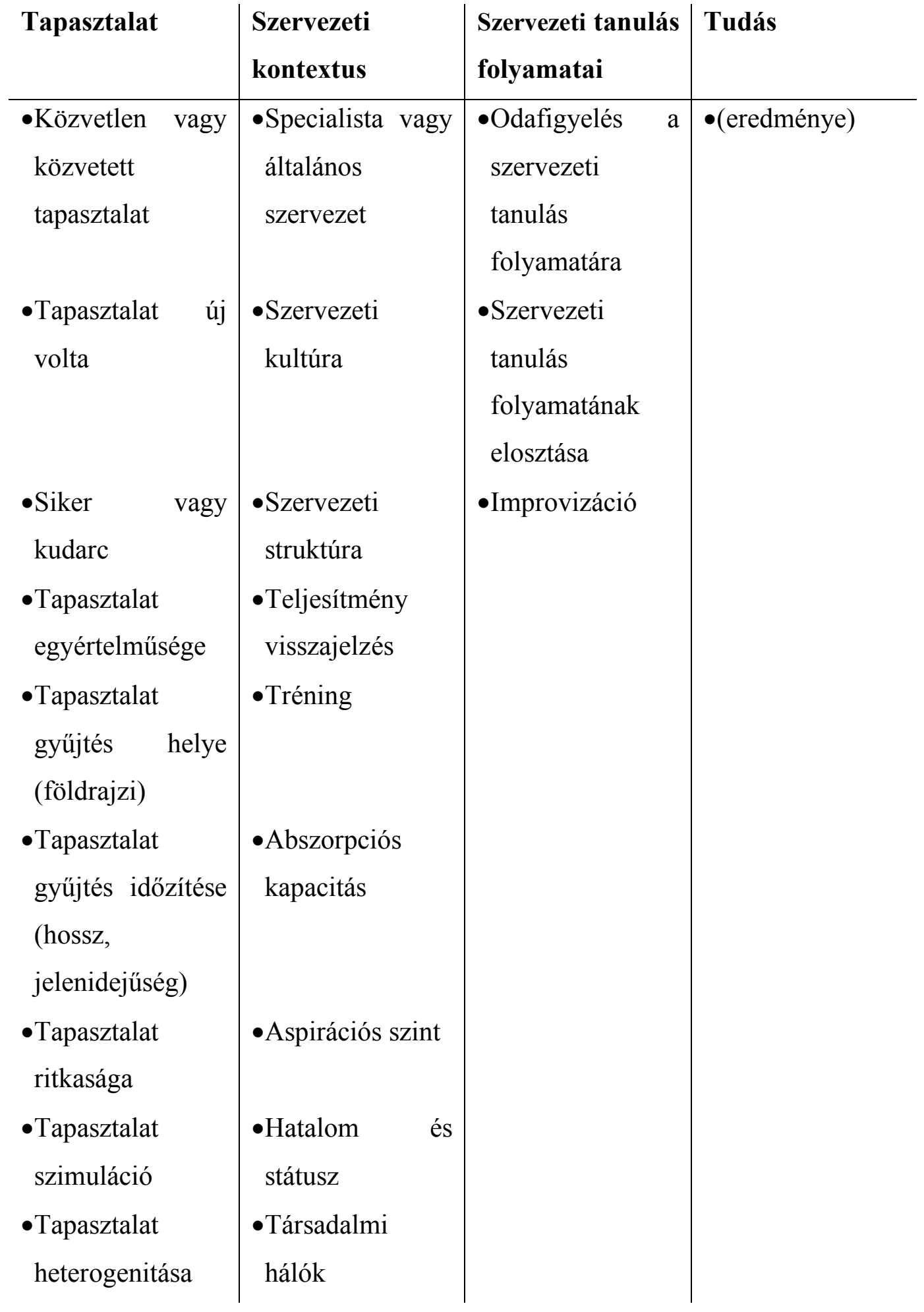




\begin{tabular}{l|l|l|l} 
Tapasztalat & $\begin{array}{l}\text { Szervezeti } \\
\text { kontextus }\end{array}$ & $\begin{array}{l}\text { Szervezeti tanulás } \\
\text { folyamatai }\end{array}$ & Tudás \\
\hline$\bullet$ Tapasztalat & $\bullet$ Tagok & & \\
üteme & diverzitása és & & \\
stabilitása & & \\
& $\bullet$ Eszközök & &
\end{tabular}

Táblázat 10: A szervezeti tanulás modelljének tényezői

Forrás: Argote (2012) alapján saját szerkesztés

A szerző a környezeti tényezöket kétfelé bontva megkülönbözteti a tanulás vállalaton belüli (látens) valamint a külső környezeti kontextusát. A környezet más kutatások szerint is kiemelt fontossággal bír a szervezeti tanulás folyamatában. Az eltérő közeg(kontextus) eltérő módon stimulálhatja a tudás gyarapítását: a bizalmi közeg segíti a szervezeti tanulást (Levin-Cross, 2004); a közeg, ahol részletes folyamat specifikáció áll rendelkezésre, segíti a tudás megtartását (Ton-Huckman, 2008); a fölérendelt identitással rendelkező csoportokban könnyebb a tudás transzfer (Kane, 2010), stb.

Létezik más megközelítés is, ahol a kontextuális tényezők helyett a szervezet belső folyamataira helyeződik a hangsúly a szervezeti tanulás megértésében. Ebben a megközelítésben a szervezeti tanulás az új tudás beépülését jelenti a meglevő tudásbázisba, a tudásmenedzsment folyamatokon keresztül:

Pemberton - Stonehouse (2000) a vállalaton belül zajló folyamatokat világítja meg a szervezeti paraméterek (kultúra, struktúra, infrastruktúra) figyelembe vétele mellett. A sikeres szervezeti tanulás kulcsa a szerzők szerint az, hogy a tanulási folyamatot a tudásmenedzsment folyamatával kell ötvözni. A két folyamat ellenkező irányba dolgozik: előbbi az új tudás megszerzését, gyarapítását célozza, utóbbi viszont a formalizációt, a tudás elraktározását és megosztását, disztribúcióját segíti.

\section{A szervezeti tanulás szintjei}

A szakirodalom a szervezeti tanulás négy szintjét különbözteti meg, melynek jellemzőit az alábbi táblázat foglalja össze: 56 


\begin{tabular}{|c|c|c|c|}
\hline & Jellemzője & $\begin{array}{l}\text { Lépcsőfok a } \\
\text { következő szintre }\end{array}$ & $\begin{array}{l}\text { Tanulási } \\
\text { kontextus }\end{array}$ \\
\hline Egyéni szint & $\begin{array}{l}\text { - Folyamatos tanulás } \\
\text { - Munkavállalók belső } \\
\text { ösztönzésen alapul } \\
\text { - Próbálkozás-hibázás, } \\
\text { kérdésfeltevés (a) }\end{array}$ & $\begin{array}{l}\text { Intuíció, } \\
\text { értelmezés (b) }\end{array}$ & $\begin{array}{l}\text { Csapat, szervezeti } \\
\text { és szervezetközi } \\
\text { szint (c) }\end{array}$ \\
\hline Csapat szint & $\begin{array}{l}\text { - Kollaboráció } \\
\text { • „Megtanulni tanulni” } \\
\text { (a) }\end{array}$ & Integráció (b) & $\begin{array}{l}\text { Szervezeti és } \\
\text { szervezetközi } \\
\text { szint (c) }\end{array}$ \\
\hline $\begin{array}{l}\text { Szervezeti } \\
\text { szint }\end{array}$ & $\begin{array}{l}\text { - Tanulásra ösztönző } \\
\text { impulzus } \\
\text { - Tudás előállítása, } \\
\text { felhasználása, } \\
\text { megosztása (a) }\end{array}$ & $\begin{array}{l}\text { Intézményesítés, } \\
\text { összefonódás (b) }\end{array}$ & $\begin{array}{l}\text { Szervezetközi } \\
\text { szint (c) }\end{array}$ \\
\hline $\begin{array}{l}\text { Szervezetközi } \\
\text { szint }\end{array}$ & $\begin{array}{l}\text { - A szervezet a } \\
\text { környezetéhez } \\
\text { csatlakozik } \\
\text { - A szereplők víziója } \\
\text { azonos (a) }\end{array}$ & - & \\
\hline
\end{tabular}

Táblázat 11: A szervezeti tanulás egyes szintjeinek jellemzője

Forrás: (a): Schuchmann-Seufert (2015), p33; (b): Tam-Gray (2016); (c): Argote (2012)

A témával foglalkozó szerzők egy érdekes kettősségre is ráirányítják a figyelmet. Habár a csapat valamint szervezeti szintü tanulás mechanizmusa isaz egyéni szintre vezetődik vissza, az egyéni szintü tanulás önmagában nem elégséges a magasabb szintü tanuláshoz - ahhoz arra is szükség van, hogy az egyén által birtokolt tudás a többiek számára valamilyen formában hozzáférhető legyen.

Az egyéni szintű tanuláshoz hasonló módon a csapat szintű tanulás is kiemelt fontosságú. A csapatokat vezetői és alsóbb szinteken is egyre intenzívebb módon alkalmaznak a cégek, a csapat szintü tanulás mechanizmusának megértése így a 57 
szervezeti szintü tanulás egyik kulcsa. Ez a megállapítás már csupán azért is igaz, mivel azok a társasági (társadalmi) folyamatok, melyek a szervezet egészének az életét meghatározzák - beleértve a tanulást is -, már csoport szinten is jelentkeznek (pl. kommunikáció, tudásmegosztás, befolyásolás, kapcsolati háló, koordináció, stb). Természetesen szervezeti szinten ezek egy magasabb szinten skálázódva jelennek meg, a csoport tanulásnak viszont meg van az az előnye, hogy akár laboratóriumi körülmények között is tanulmányozható.

Ez pedig fontos előny, ami hozzájárult ahhoz, hogy az ezredforduló környékétől folyamatosan nőtt a kutatók érdeklődése a csoporttanulás iránt (ld., Edmondson et al., 2007 összefoglaló tanulmányát a témában), a kísérletek elemzése révén robosztus modelleket állítottak fel, melyek olyan kulcstényezőket emeltek a kutatások homlokterébe, mint a csoport emlékezési képesség, társadalmi befolyás, a tudás megőrzése illetve megosztása, csoport összetétel hatásai vagy éppen az új tudásanyag „előállítása” (Argote, 2012). A kutató összegzése alapján a csoporttanulás egy folyamat, melynek keretében a csoport tagjai tudást (1) osztanak meg (2) hoznak létre (3) értékelnek ki és (4) kombinálnak. Ezeket a szerző nem diszjunkt, hanem egymással átfedésben levő kategóriaként kezeli, ahol az egyes állomások közt visszacsatolás történhet. Az is előfordulhat, hogy bizonyos lépések a tanulási folyamatból kimaradnak.

Az egyéni, illetve a csoporttanulás hatékonyságát összevetve a szakirodalomban különböző megközelítésekkel illetve eredményekkel találkozhatunk.

- Van, amikor a már alapjaiban rossz kiindulópontról kezdődő „csoportgondolkodás” rendkívül rossz minőségü eredményeket ad. Ez kétségkívül egy rendkívül érdekes helyzet, melyet elsőként Irving Janis pszichológus írt körül.A kutató tragikus történelmi lépéseket elemezve állapította meg, hogy a csoportszintü döntéshozatal sokszor alatta maradt annak, ami a csoport tagjaitól, mint egyénektől elvárható lett volna (idézi: Aldag-Fuller, 1993). A csoporttanulás akadálya lehet (1) egy erőteljes, karizmatikus vezető, aki elnyomja a többieket, vagy (2) a csoporton belüli normákról való konszenzus hiánya, (3) olyan kultúra, ahol a 
megszégyenüléstől való félelem vagy fenyegetés miatt a csoporttagok nem merik felvállalni véleményüket, stb.

- A csoporttanulás/tudás lehet olyan hatékony, eredményes mint a tagok átlaga vagy a legkiválóbb tag egyéni teljesítménye

- De arra is van példa, hogy a csoport tudása, teljesítménye a legkiválóbb képességű tagjai egyéni teljesítményét is felül tudja múlni (ld. pl WeldonBellinger, 1997)

\section{A szervezeti tanulás modelljei}

Mint azt említettem, a szakirodalom különböző modelleket állított fel a szervezeti tanulásra, ezek közül többek robosztusságát empirikus úton is tesztelték. A következőkben a teljesség igénye nélkül néhányat fontosabb modellt és megközelítést mutatok be azok rövid jellemzésével:

- Muth (1986) az elsők között ábrázolta a tanulási görbét logaritmikus formában, ahol a tanulás költséghatékonysága a kulcstényező a szervezet számára. A szerző nem fókuszált arra, hogy mivel magyarázható a tanulási görbe eltérő alakja a különböző cégek között, kizárólag egyetlen szervezeten belül vizsgálta a termelési hatékonyság változását a tapasztalat függvényében.

- Huberman (2001) már ez utóbbira, vagyis a cégek közötti eltérések magyarázatára fókuszált. Modellje gráfként vizualizálható, ahol a csúcsok a folyamat állomásait, az élek a folyamatok sorrendiségét jelenítik meg, a szervezeti tanulásról pedig akkor beszélhetünk, amikor az élek változásával csökken az út teljes hossza a gráf kiinduló valamint befejező csúcsa közt. Ez két mechanizmus révén érhető el: (1) a csúcsok között új élek húzhatók vagy és ezzel a korábbi folyamat által érintett csúcsok közül egyesek elhagyhatóvá válnak (2) rövidül az élek hossza, azaz olyan hatékony kapcsolat alakul ki a csúcspontok közt, hogy bármilyen probléma esetén a szervezet tagjai pontosan tudják, milyen megközelítéssel lesz az orvosolható, és így idő takarítható meg. 
- Fang (2011) modellje Huberman modelljéhez hasonlóan a végcél eléréséhez szükséges lépcsőfokok számának csökkentését célozza, azonban tanulmánya kapcsolatot épített az egyéni tanulás és a csoporttanulás között. Modelljében a tapasztalat gyüjtés úgy jelenik meg, hogy a sikeres lépcsőfokoknak „krediteket” delegál a szervezet, a tanulás pedig a kreditek propagálása révén valósul meg: azok az állapotok, melyek a célhoz közelebb vannak, nagyobb mértékben részesülnek kreditekböl, mint azok, melyek távolabb esnek attól.

\section{Marketing képességek és szervezeti tanulás}

Mint azt a korábbi fejezetben láttuk, a szervezeti tanulás a vállalatok számára fontos versenyelőny forrás lehet (minden olyan tulajdonsággal rendelkezik, ami ezt lehetővé teszi: értékes, ritka, nehezen másolható, stb). Korábbi kutatások a szervezeti tanulást különböző fogalmakkal kapcsolták össze. Baker-Sinkula (1999) a piacorientációt a szervezeti tanulás szükséges, de nem elégséges feltételeként határozta meg, Slater-Narver (1995) szerint a két fogalom közötti kapcsolat egyfajta „közvetítő közegeként” a szervezeti kultúrát határozta meg. Day-nél (1994) a szervezeti tanulás a piacorientáció előfeltétele (és nem fordítva). Hasonlóan mélységében tanulmányozták a szervezeti tanulás kapcsolatát a fenntartható versenyelőnnyel (Vorhies et al., 1999, Day 1994, stb).

A marketing képességeket olyan integratív folyamatként definiálhatjuk, melyek célja, hogy a szervezetben összegyüjtött tudást, képességeket és erőforrásokat olyan módon alkalmazza a piaci igényekre, hogy az által a cég értéket rendeljen a megtermelt javak és szolgáltatásokhoz, kielégítve a versenyzői keresletet (Morgan et al., 2009). Ezek tehát a vállalatok olyan belső folyamatai, melyek révén a szervezet még inkább piac által vezéreltté válik. Vorhies-Morgan (2005) összesen nyolc ilyen marketing képességet különböztet meg: árazás, termék fejlesztés, csatorna menedzsment, marketing kommunikáció, értékesítés, marketing információ menedzsment, marketing tervezés és marketing megvalósítás. A szerzők két fontos megállapítást tesznek a képességek kapcsán: (1) bármelyik képesség önmagában is versenyképessé teheti a vállalatot, illetve (2) az egyes 
képességek közötti kölcsönös függőség miatt a cég kiemelkedö teljesítményt ér el, amennyiben egyszerre több ilyen képességet birtokol.

A marketing képesség és szervezeti tanulás közötti összefüggést több kutatás vizsgálta már: világos, hogy akárcsak más szervezeti képességek esetén is, a marketing képességek (ki)fejlesztése is a szervezeti tanulás révén valósítható meg (Liu-Ko, 2012; Easterby-Smith - Prieto, 2008)

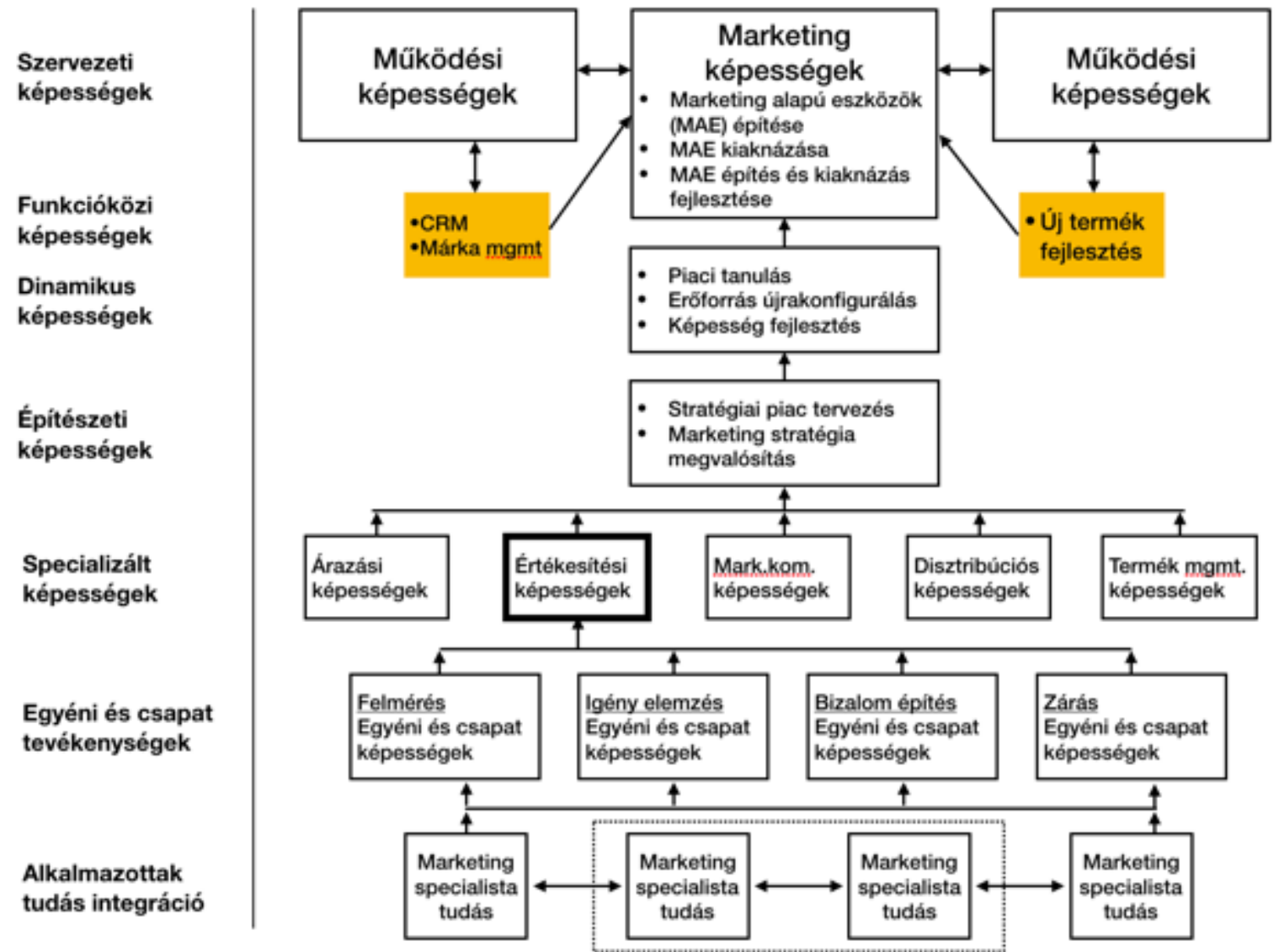

\section{Ábra 11: A marketing képességek}

Forrás:

A fenti, átfogó modellben a tanulás olyan dinamikus képesség, amelynek révén a szervezetek az erőforrások újra-konfigurálásával új képességekhez és kompetenciákhoz juthatnak (Easterby-Smith - Prietow, 2008). A témával foglalkozó kutatók szerint a dinamikus képességek lehet egy magyarázata annak, hogy egyes szervezetek miért bizonyulnak sikeresebbeknek. Zollo-Winter (2002) szerint a szervezet három mechanizmus biztosítja a kapcsolatot a tudás és a 61 
dinamikus képességek között: (1) tapasztalatgyüjtés: azaz olyan tanulási folyamat, amely a próbálkozásra, hiba-ráhibázásra épít (2) a tudás artikulálása, vagyis olyan tanulási folyamat, ahol az implicit tudást közös megbeszéléssekkel, értékeléssel, explicit tudásátadással adják tovább, illetve (3) tudás kodifikálása, ahol a tudás transzfert írásos anyagok (kézi könyv, tervek, stb) vagy szoftverek (döntéstámogató rendszer, projekt menedzsment rendszer) biztosítja. Zahra et al. (2006) szerint a dinamikus képeségek közvetítő kapocsként szolgálnak az alapvető képességek és a szervezeti tudás bázis között, ilyen módon indirekt hatással bírnak a teljesítményre.

A marketing képességek egy fontos tulajdonsága, hogy nem koncentrálódva, hanem szétszóródva jelennek meg. Ezt a jelenséget nem csak egy konkrét szervezeten belül, hanem szervezetek között is megfigyelték (Krush et al., 2015).

A cégek eltérő stratégiát alkalmazhatnak a versenyben: a skála egyik végén a környezeti kockázatok kiegyenlítését célozva a vállalati képességek, tudás általános, széles spektrumot felölelő fejlesztését találjuk, míg ennek ellentettjeként az erőforrások egy szük részterületet (képességet) érintő fejlesztésére való koncentrációját állapíthatjuk meg (Achrol, 1991).

\section{A szervezeti tanulás és szervezeti struktúra kapcsolata}

A szervezeti tanulás és a szervezeti struktúra kapcsolatára eddig nem sok kutatás fókuszált, Lam (2000) kutatásából kiderült, hogy a dolgozat korábbi fejezetében bemutatott mintzbergi szervezeti modellek milyen összefüggést mutatnak a szervezeti tanulással: 
A tudás hordozója

(autonómia és kontrol)

Az egyén

A szervezet

A tudás és a

munkafeladatok

standardizáltságának

mértéke

\begin{tabular}{l|c|c|}
\cline { 2 - 3 } Magas fokú & $\begin{array}{c}\text { Szakértöi } \\
\text { bürokrácia }\end{array}$ & $\begin{array}{c}\text { Gépi vagy } \\
\text { ipari } \\
\text { bürokrácia }\end{array}$ \\
\cline { 2 - 3 } $\begin{array}{l}\text { Alacsony } \\
\text { fokú }\end{array}$ & Adhokrácia & J-szervezet \\
\hline
\end{tabular}

\section{Ábra 12: Szervezeti modellek és szervezeti tanulás}

Forrás: Lam (2000), pp.494

A két terület közös metszetével foglalkozó kutatások eredményei is divergensnek nevezhetők (annyiban legalábbis, hogy különböző, egymással ellentétesjellemzőkkel bíró szervezeti formákat is optimálisnak találtak a szervezeti tanulásra):

- Jansen et al (2006) a szervezetek decentralizált formáját vizsgálva arra a megállapításra jut, hogy a központosítás csökkentése a felfedező innovációt bátorítja, az ilyen struktúra arra ösztönözheti a tagokat, hogya az optimális megoldást találják meg, és ne ragadjanak le attól elmaradó megoldások mellett

- Fang et al. (2010) a mérsékelt kereszt kapcsolódással bíró félizolált csoportok rendszerét találta a legjobbnak a szervezeti tanulás előmozdításában. Mivel itt a csoportok bizonyos szempontból különállók, de kapcsolódási pontokkal is rendelkeznek, így ez a rendszer egyszerre ösztönözi az ötletek generálását a csoportokon belül valamint a tudás megosztást a csoportok között

- Bunderson-Boumgarden (2010) alapján azok a csapatstruktúrák teljesítenek jól a szervezeti tanulás folyamatában, melyeket a (1) specializáció, (2) formalizáció és (3) erős hierarchia jellemez. 


\subsection{A tanuló szervezet}

A szervezeti tanulás egy magas szintjeként jelenik meg a szakirodalom a tanuló szervezet - amely fogalmat sok esetben nem leíró, hanem már-már normatív éllel használnak a kutatók. (Ebben az értelmezésben a tanuló szervezet olyan szemléletbeli reform, átalakulás, amely garantálja a vállalatok fejlődését, túlélését - Pedler-Burgoyne, 2017). A tanuló szervezet az ezredforduló körül ismét a kutatások fókuszába került (Örtenblad, 2013) a szakirodalomban rendszerint az innovációval, hatékonysággal, versenyképességgel hozzák összefüggésbe: egy definíciója szerint „olyan szervezet, amely képes tudást létrehozni, megszerezni, és transzferálni, valamint képes saját viselkedését módosítani az új tudás, belátás tükrében" (Garvin, 1993 pp. 80).

Hasonló megközelítést alkalmaz Tomas et al. (2015). Az általuk javasolt elméleti keretben a hagyományos szervezetekkel szemben a tanuló szervezet legmagasabb szintjeként a marketing-orientált tanuló szervezet jelenik meg (ld. lenti ábra). A szerzők terminológiájában ez a teljes tanuló marketing szervezet, ahol a külső és belső irányú fókusz kombinálásával elégítik ki, sőt előzik meg a piacok igényeit (a hagyományos és a teljes tanuló marketing szervezet összevetését ld. lenti ábrákon):

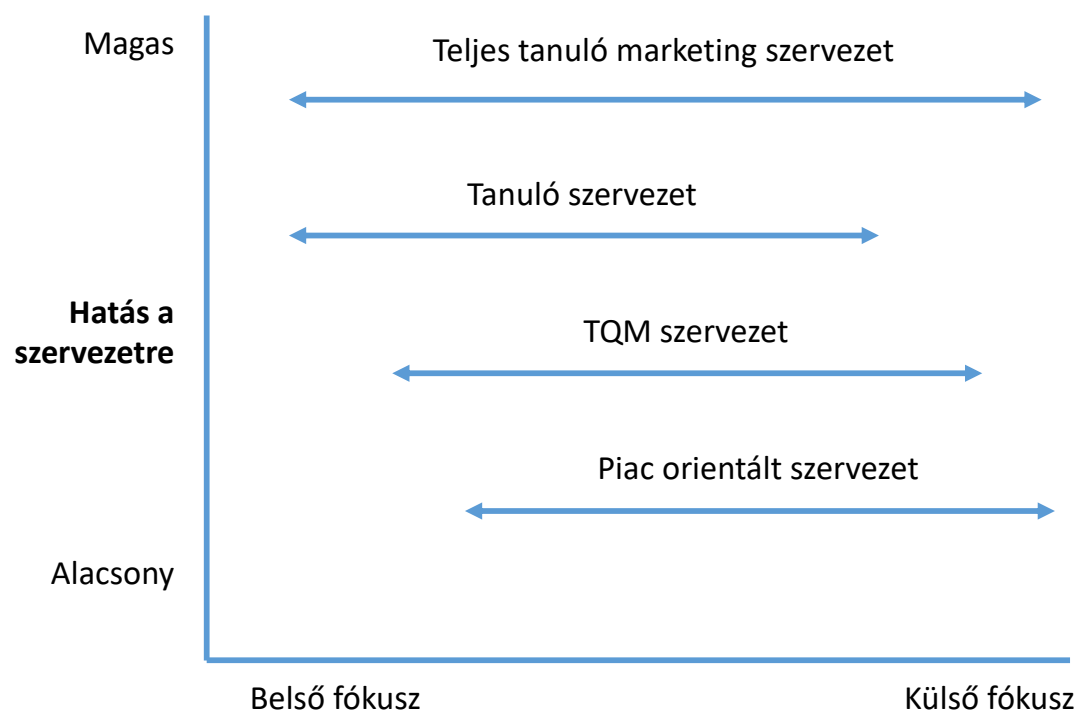

\section{Ábra 13: Teljes tanuló marketing szervezet}

Forrás: Tomas et al. (2015), pp. 140 
Egyértelmü, hogy a tanuló szervezet és a szervezet innovációra való fogékonysága között egyenes arányú kapcsolat áll fenn (Hurley-Hult, 1998), Slater-Narver (1995) alapján pedig a piaci orientációval is elválaszthatatlanul összekapcsolódó fogalom.

A tanulószervezeteket Senge (2014) szerint az alábbi jellemzők határozzák meg:

- Rendszerben történő gondolkodás: a szervezet észleli, hogy maga is egy nagyobb rendszer részét képezi, tudatosítja ennek belő alrendszereit. Észleli és értelmezi a rendszer alrendszereit, tisztában van azzal, hogy az egyes alegységeket érintő hatások más egységekre is hatással bírnak

- Gondolati minták: a szervezet felszínre hozza, tudatosítja azokat a gondolati mintákat, melyek révén a napi, automatikus (rutin) döntéshozatal lezajlik. A tudatosítás révén szükség esetén a gondolati minták újra írhatóak és értelmezhetőek.

- Személyes kiválóság: a szervezet személyi állománya önmegvalósító személyekre épül, akik hatékonyságuk fokozására teszik a hangsúlyt a munka területén, személyes kapcsolataikban egyaránt. A szervezet teret biztosít az önmegvalósítás számára, nem csak a felső vezetők, hanem a munkavállalók széles rétegei előtt is - az emberek azokért a célokért dolgoznak, melyek számukra valóban fontosak

- Közös jövőkép kialakítása: elköteleződés a döntési folyamatokban való részvétel által. Felülről kijelölt célok helyett a tanuló szervezet biztosítja a lehetőséget, hogy a munkavállalók részt vegyenek a folyamatokban, és nem csak a látszatát adja ennek.

- Csoportos tanulás: felülről kijelölt irányok helyett több nézőpontot vizsgálnak, a vita helyett dialógus a domináns érdekérvényesítési és ütköztetési formula. A másként gondolkodók nem ellenfelek, hanem szövetségesek, a munkavállalók közötti csatározások helyett a szinergiák kihasználására törekednek. Ennek révén nem csak a konfliktuskezelés hatékonyabb, de a tudás közössé válik, ami a szerző szerint „élő tudásmenedzsmentet" biztosít a szervezet számára. 
Látható, hogy a tanuló szervezet a folyamatok, szervezeti kultúra és az outputok szintjén is eltér a más szervezeti formáktól. Yang et al. (2004) a tanuló szervezetet olyan hálózatként írja le, ahol az egyéni és strukturális (szervezet) szint közötti kapcsolat magyarázza a szervezeti tanulást. Az egyének számára nyitott a folyamatos tanulás lehetősége, a közeg bátorítja a pábeszédet és kollaborációt, a munkavállalók (szervezeti tagok) fel vannak hatalmazva és egy közös vízió alapján cselekszenek. A szervezet egészére pedig a környezettel való szoros kapcsolat, a tudás és tanulási folyamat megosztása a jellemző.

\section{Tanuló szervezet és szervezeti felépítés, átalakítás}

A tanuló szervezet kialakítása jelentős szervezeti átalakítást igényel. Marquardt az alábbiak szerint összegezi a tanulószervezetek fontosabb jellemzőit:

\begin{tabular}{|l|l|l|}
\hline Dimenzió & Korábban & Tanuló szervezetnél \\
\hline Kritikus feladat & Fizikai & Gondolati \\
\hline Kapcsolatok & Hierarchikus & Peer-to-peer \\
\hline Szintek száma & Sok & Kevés \\
\hline Struktúra & Funkcionális & $\begin{array}{l}\text { Multidiszciplináris } \\
\text { csapatok }\end{array}$ \\
\hline Határok & Rögzítettek & Átjárhatóak \\
\hline Kompetití́v előny & Vertikális & $\begin{array}{l}\text { Kiszervezés } \\
\text { szövetségek }\end{array}$ \\
\hline $\begin{array}{l}\text { Mantegráció } \\
\text { stílus }\end{array}$ & Tekintélyuralmi & Résztvételi \\
\hline Kultúra & & Eeleegyező \\
\hline Csapattagok & Homogén & Diverz \\
\hline Stratégiai fókusz & Hatékonyság & Innováció \\
\hline
\end{tabular}

Táblázat 12: Hagyományos és tanulószervezetek összehasonlítása

Forrás: Marquardt (2011), pp.11

A kutató külön kiemeli, hogy tanuló és nem „tréning” szervezetről van szó, jellemzése szerint az utóbbi stabil környezeti feltételek mellett, az emberek 66 
(csapattagok) fejébe „kívülröl beleöntött”, elsősorban tudás, képesség jellegü tanulmányt jelent, ahol az elérendő cél a fejlesztés. A tanuló szervezetben ezzel szemben a tagok saját belső motivációjuk által vezérelve tanulnak, a fókusz az értéken, attitüdön, innováción van, ezzel segít abban, hogy új, innovatív megoldásokat találjanak a kihívásokra: a cél ugyanis nem a fejlesztés, hanem az „áttörés” (Marquardt, 2011).

Habár a szerző által rögzített differencia a „régi” és a tanuló szervezet között nyilvánvalóan egyoldalú (nem minden szervezet indul(t) neki a tanuló szervezetté válásnak olyan feltételrendszerből, amit Marquardt a „korábbi állapot”-ként rögzített), az jól látható, hogy a tanuló szervezetté való válás folyamata komoly szervezeti erőforrást (idő- és pénzügyi befektetést) igényel. Chau et al. (2015) három nagyobb lépést azonosítbe a tanuló szervezetté történő átalakulás folyamatában:

1. A tanuló szervezeti alapok meghatározása (háttér kutató munka és felderítés)

2. A csoport tanulói stratégiájának beazonosítása

3. Visszacsatolás a tanulási folyamatra

A feladat léptékét jelzi, hogy a szerzők által hozott esetek mindegyikében a tanuló szervezet kialakítása (stratégia implementációja ) 2-4 éves időtartamot ölelt fel, melyben előtesztek (pilot projektek), és fokozatos implementáció is szerepet kapott.

\section{A digitalizáció és a szervezetek}

Az elméleti áttekintésben eddig két nagy témakört boncolgattam, bemutatva a közösségi médiával valamint a szervezet elmélettel (főként a szervezeti struktúrával) foglalkozó kutatások releváns eredményeit. A következő blokkban a két kutatási terület közös metszetét tekintem át, a saját kutatásom is ennek a két téma egymással való viszonyát vizsgálja. A közösségi média - mint az láttuk - egy fiatal terület, az itt végzett kutatások csupán elenyésző hányada érintett szervezetelméleti kérdéseket is. 
A témát ezért eggyel általánosabb szintről kezdem, és megvizsgálom, hogy egyéb IT-közeli terület (ERP ill. MIS rendszerek) bevezetése milyen szervezeti átalakulásokat indukált. Ez nem jelenti azt, hogy a menedzsment információs ill. vállaltirányítási rendszereket minden szempontból hasonlónak tartanék a közösségi médiához, sőt, úgy vélem, hogy a különbözőségek igen jelentősek. Azonban mind a kettőt az informatika irányából érkező változásnak tekintek, melyeknek a szervezeti következményei fontosak (a két terület feltételezett különbségeiröl ld. a 13. táblázatot).

\subsection{ERP/MIS rendszerek és szervezeti átalakulás}

A „technológia” sokáig pusztán egyike volt a vállalat számtalan jellemzőjének, alkotóelemének. Hozzávetőlegesen a '90-es évektől kezdődően mind több kutatás mutatja, hogy az IT mélyen a szervezetek szövetébe épülve elválaszthatatlanul összefonódott azzal: nem csak munkaeszköz, de a vállalati dolgozók kommunikációs és társadalmi közegévé válva a szervezet „szövetének” részévé vált.

Hogyan jutottunk el idáig? A technológia és szervezet kapcsolata bő 60 éve áll a kutatások fókuszában. Thompson-Bates (1957) elsőként vetette fel, hogy az alkalmazott technológia a szervezeti forma egyik meghatározó előfeltétele lehet, a kontingencia elméletben pedig a szervezeti struktúrát meghatározóhárom tényező egyike (Zammuto et al., 2007). Habár az internet forradalom, és az ezzel együtt járó, a korábbiakban már bemutatott változás döntően a XX. század utolsó éveiben indult meg, már az ezt megelőző évtizedekben is voltak olyan szervezeti átalakulások, melyetszámítástechnikai, MIS/ERP rendszerek indukáltak.

Az információs rendszerek diszciplína, valamint szervezetelméleti kutatók figyelmét nem kerülte el ez a kutatási terület. Mielött ennek az áttekintésére rátérnék, először a különbözőségekről ejtek szót. Röviden bemutatom, hogy ezeknek a rendszereknek a vállalati alkalmazása -a sok hasonló vonás mellett milyen módon tér el a közösségi média (DSMM) alkalmazásától. 


\begin{tabular}{|c|c|c|}
\hline & $\begin{array}{l}\text { Hagyományos (ERP- } \\
\text { jellegü) rendszerek bevezetése }\end{array}$ & $\begin{array}{l}\text { DSMM alkalmazások } \\
\text { bevezetése }\end{array}$ \\
\hline $\begin{array}{l}\text { A rendszer fizikai } \\
\text { helye }\end{array}$ & $\begin{array}{l}\text { A szervezeten belül / saját } \\
\text { szervereken vagy felhő, } \\
\text { SaaS }\end{array}$ & $\begin{array}{lr}\begin{array}{l}\text { Jellemzően } \\
\text { szolgáltatónál }\end{array} & \begin{array}{r}\text { külső } \\
\text { (felhő }\end{array} \\
\text { alapú, } & \text { SaaS } \\
\text { szolgáltatás) } & \end{array}$ \\
\hline $\begin{array}{l}\text { A változás vezetője } \\
\text { („champion”) }\end{array}$ & $\begin{array}{l}\text { Felsővezetés, IT osztály } \\
\text { segítségével }\end{array}$ & $\begin{array}{l}\text { Marketing (külső } \\
\text { tanácsadók) }\end{array}$ \\
\hline $\begin{array}{l}\text { Változás által érintett } \\
\text { kör }\end{array}$ & Vállalat egésze & $\begin{array}{l}\text { Marketing, HR, külső } \\
\text { szervezetek } \\
\text { (ügynökség, } \\
\text { tanácsadó). Kisebb } \\
\text { részben: IT, szervezet } \\
\text { egésze }\end{array}$ \\
\hline $\begin{array}{l}\text { Fogyasztó érintkezése } \\
\text { a rendszerekkel }\end{array}$ & $\begin{array}{l}\text { Indirekt/áttételes hatásokon } \\
\text { keresztül (kisebb részben } \\
\text { közvetlenül) }\end{array}$ & Közvetlenül \\
\hline Fö cél & $\begin{array}{l}\text { Belső vállalati folyamatok } \\
\text { (újra)szervezése, javulás: } \\
\text { hatékonyság/termelékenység }\end{array}$ & $\begin{array}{l}\text { Kommunikációs } \\
\text { csatorna a vállalat } \\
\text { érintettjeivel }\end{array}$ \\
\hline
\end{tabular}

Táblázat 13: Az ERP és a DSMM rendeszerek bevezetésének feltételezhető különbségei

Forrás: saját szerkesztés

A szakirodalom a technológia és szervezet kapcsolatát mélységében vizsgálta, Zammuto et al., (2007) ugyanakkor egy érdekes, fordított irányú kapcsolatra is rávilágított. Miközben a hétköznapi életben is tapasztalható módon az IT eszközök mind szélesebb teret hódítottak meg, a szervezet-technológia kapcsolatot a '60-'70 évek fordulóján vizsgálták a kutatók a legintenzívebb módon ezt követően a 2000es évek elejéig gyakorlatilag minimális érdeklődés volt kimutatható, majd az ezredforduló után ismét felélénkült a téma kutatása. A szerzők ennek okát abban látták, hogy maga az IT, mint üzleti funkció is háttérbe szorult, elsődleges feladatai 
a meglevő tevékenységek automatizálásában valamint a kommunikáció felgyorsításában merültek ki.

Érdekes módon nem csak ebben mutatkozik különbség: egészen a '90-es évekig csak elvétve található cikk, amely a technológiába történő befektetés és a termelékenység közötti pozitív kapcsolatot mutatott volna ki. Az ezredforduló környékén ez változóban volt. Dedrick et al., (2003) metakutatásában a szervezet és technológia kapcsolatának egy fontos aspektusára világított rá. A szerzők 55 kutatás eredményeit összegezve arra a következtetésre jutottak, hogy az IT rendszerekbe történő invesztálás növeli a termelékenységet - feltéve, hogy ezzel párhuzamosan a cég a szervezeti fejlesztésre is költ.

A kutatások egy része arra fókuszált, hogy az ERP/MIS rendszerek bevezetése milyen lényegiátalakulásokat indukál a szervezetben. Az (M)IS szakirodalom a siker kulcsát a rendszer szervezeti illeszkedésében látja, a két tényező kapcsolatát pedig különböző környezet- és szervezet-specifikus tényezők befolyásolják (HongKim, 2002). A szervezeti illeszkedést részleteiben megvizsgálva ugyanakkor különböző megközelítés módokkal találkozhatunk a szakirodalomban:

- Henderson-Venkatramn (1993) az üzleti és az IT stratégia, valamint az üzleti és IT infrastruktúra/folyamatok egymáshoz illeszkedése alapján alkotta meg a stratégiai illeszkedési modelljüket

- Holland-Light (1999) stratégiai és taktikai szintű tényezőket azonosított be a folyamatban - stratégiai szintre sorolták a bevezetendő ill. már meglevő informatikai rendszereket valamint a felső vezetés támogatását. Taktikai szinten pedig föként a kommunikációval (ügyfél-vállalat, vállalton belül, stb) illetve a munkavállalók hozzáállását azonosították be.

- Nah et al (2003) pedig a Forbes 1000 vállalati körben végzett felmérés alapján az alábbi tényezőket sorolta fel, mint a változásmenedzsment kulcsfontosságú tényezői: a felsővezetés támogatása, csapatmunka, projektés változás menedzsment, valamint a vállalati kultúra 
Hong-Kim (2002) összegezve az alábbi tényezőkbe sorolja az addig megjelent kutatások alapján a sikertényezőket: stratégia, vállalati struktúra és méret, környezet, technológia, feladatok és egyéb, egyéni tényezők.

Az új típusú kommunikációs eszközök (pl. mobil) illetve médiumok (pl. közösségi hálózat) robbanásszerü fejlődése legkevesebb két vállalati terület életét alakítják át, hiszen a marketing mellett az informatikai osztályok érintettsége is joggal merülhet fel. Több szerző érvel amellett például, hogy a jövőben a két terület vezetőinek szorosan együtt kell müködniük annak érdekében, hogy „,kielégitsék és stratégiai szinten elkötelezzék a vevöket a teljes életciklus során - ez pedig az üzleti növekedés motorja” (PR Newswire, 2014, pp1.). Ezt támasztja alá, hogy például a közösségi média és a szervezetek kapcsolatával nem csak marketing, hanem például az információ technológia és menedzsment információs rendszerek területeken publikáló akadémikusok is rendszeresen foglalkoznak.

Fehér et al. (2017) kutatása alapján is kijelenthető, hogy a marketing és az IT terület egyre szorosabb összefonódást mutat. Kutatásukban a szerzők feltárták, hogy a magyar vállalatok informatikai osztálya olyan, a marketinghez kapcsolódó digitalizált területeken élnek önálló indítványokkal, mint a közösségi média vagy a „big data”.

\subsection{A közösségi média, mint diszruptív technológiai innováció}

A diszruptív innovációt - mint azt rövidesen bemutatom - számos szerző tartja a számon a 21. század legfontosabb üzleti fogalmai sorában. A vállalatok számára nagy kihívást jelent a diszruptív innovációk kezelése - hiszen azoknak már a felismerése is komoly problémákba ütközhet. Miközben a megjelenő innovatív megoldás, szolgáltatás vagy termék új távlatokat nyit, megsemmisíti a korábbi létezőket, ami nem csak a termékeket, de akár a megelőző éra üzleti modelljeit, elméleti kereteit is átalakítja. Ennek köszönhető, hogy az ezzel kapcsolatos előrejelzések készítése hasonlóan problémás. A kutatóknak olyan összetett kérdésekre kell válaszolniuk, mint hogy miként illeszkednek ezek az innovációk egy átfogóbb keretbe, miközben a már meglevő elméleti modellekkel való illeszkedést is vizsgálni kell (Pegoraro, 2014). 
Ha a számítástechnika két alaptörvényét, (1) Moore $^{6}$ és (2) Metcalf ${ }^{7}$ nevéhez füződő törvényeket megvizsgáljuk, akkor azt találjuk, hogy a technológiai fejlődést csak exponenciális görbével írhatjuk le. Kristóf (2016) jövőkutatókra hivatkozva megfogalmazza azt, hogy az informatika a különböző iparágakba betörve ezzel a nemlineáris fejlődéssel együtt korábban nem tapasztalt átrendeződéseket hoz, ami „ami az ár/érték arány évenkénti duplázódásával jellemezhető” (pp.6). Ezt a környezetet vizsgálva egyértelmüen adódik korunk legnagyobb menedzser dilemmája: a technológiai fejlődés üteme túlszárnyalja a szervezetek adaptációs képességét. A kutatók előtt álla feladat, hogy - a korábban bemutatott alapokra építkezve, de azokat meg is haladva -választ találjanak arra: melyek azok a kulcs változók, fogódzkodópontok, melyek révén a szervezetek visszanyerhetik a környezet feletti kontroll képességét.

A diszruptív innováció fogalmát - bár korábban is létezett -illetve annak ,újbóli bevezetését" a Bower-Christensen (1995) szerzőpáros nevéhez köthető (a diszruptív innovációt számtalan alkalommal sorolták az új évszázad eddigi legfontosabb üzleti fogalmai közé). A szerzők alapvetően két csoportra bontják az innovációt: olyan újításokra, melyek alapvetően nem forgatják fel a meglevő piacokat (erre példa az autók megjelenése a 19. század végén, melyek luxus termékként nem jelentettek különösebb kihívást a lóvontatású járművek piacára), és a diszruptív innováció, amely úgy teremt magának piacot, hogy ezzel párhuzamosan megsemmisít más vagy másokat (pl. Ford T-model - hintók, és egyéb lóvontatású közlekedési eszközök).

${ }^{6} \mathrm{Az}$ integrált áramkörök összetettségére vonatkozóan azt mondta ki, hogy az nagyjából másfél évente megduplázódik - a „törvény” „végéről” az elmúlt években számos cikk jelent meg

${ }^{7}$ Egy hálózat hasznossága négyzetesen nő a hálózat csomópontjainak a számával. Vagyis: az internet (hasonlóan a telefonhoz, mobiltelefonokhoz), egyre értékesebb, amint egyre többen kapcsolódnak be. 
A diszruptív innovációval előálló vállalatok három kritikus sikertényezője (Skarzynski - Rufat-Latre, 2011) alapján:

1. Váratlan piaci változásokra és kielégítetlen vevői szükségletek előre jelzésének valamint az arra való reagálásnak a képessége, kiemelten az üzleti modellre fókuszálva

2. Az inkrementális és az áttörés jellegü innovációs erőfeszítések egyetlen, közös törekvésben való egyesítésének a képessége

3. A stratégiai tervezés és az új lehetőségek felfedezésének kölcsönös egymásrautaltságát feltételező hozzáállás.

Teixeira (2015) a digitális diszrupció három hullámát különböztette meg:

1. hullám: „szétcsomagolás” (unbundling): a korábban azonos platformon nyújtott szolgáltatásokra (pl. Daily Telegraph - hírek, hirdetések, étterem kritika) külön-külön online szolgáltató specializálódnak (pl. Google - hírek, craigslist - hirdetések, yelp - étterem kritika)

2. hullám: közvetítőlánc felaprózása: a korábban egy szolgáltató által egy helyen nyújtott szolgáltatásokat (pl. utazási ügynökségnél vásárolt szállás + utazás + szabadidős programok) a fogyasztók saját maguknak válogatják össze, eltérő platformokon

3. hullám: „szétpárosítás” (decoupling): a fogyasztói vásárlási folyamat egyes lépései közötti kapcsolat megtörése (pl: fogyasztói kosár értékesítése - ahol az értékelés és a választás között nincs kapcsolat; online vásárlás - amit a fogyasztó offline korábban kiválasztott; online játék: fogyasztás vásárlás nélkül, stb).

Teixeira szerint a harmadik hullám alapvetően különbözik a korábbi hullámoktól. A diszruptív innováció korábbi eseteinél már megszokott „rombol” + „értéket teremt” kettős mellett a szétpárosításnál más kombinációk is megfigyelhetők: (1) mind a két fél számára értéket teremtő tevékenységek (pl. twitch, ahol a játékot készítő valamint a játékot közvetítő cég számára is pénzügyi hasznot hajt), (2) érték romboló + érték teremtő, (3) érték megragadó és érték teremtő (ahol az egyik fél haszna pénzügyi, a másik fél számára valamilyen egyéb - pl reklám, márka, stb - 
érték teremtődik). A szerző azt is megállapítja, hogy a szétpárosítás hajtóereje az az által elérhető költségelőnyök: a keresés, a vásárlás ill. a használat költségei csökkenthetők.

Napjaink digitális forradalma legkevesebb három olyan területen hozott alapvető változást, ami vállalatok munkavállalókkal való viszonyát is érinti:

1. A munka természetének a változása, ami érinti a napi folyamatokat, a munkavállalók egymáshoz való viszonyát, belső szervezeti egységeket is (funkciók, csapatok, feladatkörök, stb)

2. Az adat természetének a változása, ami egyértelmüen a rendelkezésre álló információ volumenének exponenciális bővülésével hozható összefüggésbe (ld. big data)

3. A munkaerő dinamikájának a változása - vagyis a megváltozó etnikai, generációs tényezők, valamint az ezzel összefüggésben álló értékstruktúrák, elvárások, stb átalakulása. (Church-Burke, 2017)

A DSMM technológiák robbanásszerü terjedése nem csak a fejlődés gyorsaságában, de méreteiben és gazdasági hatásaiban is példa nélkülinek tekinthető. A technológiai fejlődés üteme hatást gyakorol a vállalatok, a termékek életciklusára. A menedzserek döntési időhorizontja csökken, a rendelkezésre álló erőforrások elosztásáról a korábbiaknál gyorsabban kell tudni dönteni (Vassileva, 2017). Érdekes kérdés lehet, hogy a piacon most megjelenő technológiák (mesterséges intelligencia, kiterjesztett valóság, stb) milyen módon lesznek képesek támogatni, vagy adott esetben kiváltani azokat a döntési helyzeteket, melyek most még emberi beavatkozást igényelnek.

A helyzet tehát két irányból is nyomasztóan hat a marketing szervezetre, menedzserekre:

- nagyobb volumenủ adat áll rendelkezésre, melynek elmélyült elemzése ezért a korábbiaknál nagyobb időt igényel(ne) 
- a rövidülő termék életciklus, a turbulens müködési környezet miatt a menedzsment számára követelményként jelenik meg a korábbiaknál gyorsabb döntéshozatal.

Ezek a tényezők együttes hatásaként a szervezeteknek át kell alakítani belső struktúrájukat, meg kell változtatni a szervezeti kultúrát, hatásköröket, de még a szervezet határait is újra kell értelmezni. Ezt röviden úgy foglalhatjuk össze, hogy újra fel kell találniuk saját magukat. A szerzők a konzekvenciákat vizsgálva a szervezeti változások kapcsán megállapítják: a cégek életében mind inkább a tehetség kerül a fókuszba a „szimpla” munkavállalókkal szemben (Church-Burke, 2017)

Kutatások igazolták, hogy a közösségi média alkalmazások a marketing hagyományos müködési területein több esetben diszruptív innovációként értelmezhető folyamatokat indítottak el:

- A fogyasztókkal való kommunikációban nem csak a csatorna, de a domináns kommunikációs modell is megváltozott (one-to-many helyett many-to-many kommunikáció), a folyamat feletti kontroll a cégektöl a közösség kezébe került át, és a korábban csak a vállalatokra jellemző, erős pozícióba kerültek a vállalati müködés egyéb érintettjei is (beszállítók, fogyasztók, kormányzat, helyi közösségek, stb). A folyamat hátrányosan érinti a tömegmédiumokat

- A közösségi kereskedelem (social commerce) a B2C, B2B valamint C2C kereskedelemben is átalakulást hoz. Nincs arra vonatkozó adat, ami arra utalna, hogy ez a hagyományos és/vagy online kereskedelmet teljes megsemmisüléssel fenyegetné, ugyanakkor mindegyik érintett területen jelentős szerepre tehet szert. A fogyasztók egymás közötti kereskedelmében (C2C) a meglevő platformokat akár teljesen leválthatja

- A közösségi média applikációk a hagyományos piackutatási feladatok kiváltására is alkalmasak. A rendelkezésre álló, nagy mennyiségü adat (big data) olyan fogyasztói insight-ok felismerését teszik lehetővé, melyek más eszközökkel nem is lennének feltárhatók. A legújabb eszközök (pl. 
tartalomelemzés - sentiment analysis, adatbányászat, stb) pedig korábban elképzelhetetlen mélységű és szélességű adatokhoz való hozzáférést biztosítanak

- De bizonyos iparágak/szereplők esetén a közösségi média a cégek által kínált alapszolgáltatást (alapterméket) is megszünéssel fenyegeti. Ide sorolható a kreatív- és kulturális szektor (Flew, 2017), újságok, napilapok (Miranda et al., 2016) vagy éppen az oktatás (Anderson, 2016)

Ezeket a jelenségeket az alábbi táblázat foglalja össze:

\begin{tabular}{|c|c|c|c|}
\hline $\begin{array}{l}\text { Marketing } \\
\text { tevékenység }\end{array}$ & $\begin{array}{l}\text { Példa közösségi } \\
\text { média applikáció }\end{array}$ & $\begin{array}{l}\text { Hátrányosan érintett } \\
\text { szektor/versenytárs }\end{array}$ & Forrás \\
\hline Kommunikáció & Twitter, Facebook & $\begin{array}{l}\text { Tömegmédia } \quad \text { (televízió, } \\
\text { újságok, } \\
\text { magazinok) }\end{array}$ & $\begin{array}{l}\text { Pegoraro } \\
(2014)\end{array}$ \\
\hline Értékesítés & $\begin{array}{l}\text { Facebook } \\
\text { Marketplace } \\
\text { (C2C), Facebook } \\
\text { Shop } \quad \text { (B2C), } \\
\text { LinkedIn (B2B) }\end{array}$ & $\begin{array}{l}\text { Különösen: } \quad \mathrm{C} 2 \mathrm{C} \\
\text { kereskedelem } \\
\text { platformjai, } \quad \text { kevésbé: } \\
\text { online/offline értékesítési } \\
\text { csatornák }\end{array}$ & $\begin{array}{l}\text { Ghezzi et al. } \\
\text { (2016) }\end{array}$ \\
\hline $\begin{array}{l}\text { Piackutatás, } \\
\text { fogyasztói } \\
\text { insight }\end{array}$ & $\begin{array}{l}\text { Facebook, Twitter, } \\
\text { YouTube, blogok, } \\
\text { stb }\end{array}$ & Piackutató cégek & $\begin{array}{l}\text { Ghezzi et al. } \\
(2016)\end{array}$ \\
\hline $\begin{array}{l}\text { Alaptermék/ } \\
\text { alapszolgáltatás }\end{array}$ & $\begin{array}{l}\text { Bármely közösségi } \\
\text { média applikáció }\end{array}$ & $\begin{array}{l}\text { Kreatív- és kulturális } \\
\text { szektor, újságok } \\
\text { hagyományos média, } \\
\text { oktatás }\end{array}$ & $\begin{array}{l}\text { Flew (2017), } \\
\text { Miranda et al., } \\
(2016), \\
\text { Anderson } \\
(2016)\end{array}$ \\
\hline
\end{tabular}

Táblázat 14: A közösségi média, mint diszruptív innováció

Forrás: saját szerkesztés

Felix et al. (2015) arra mutat rá: a vállalati kultúrának meghatározó szerepe van abban, hogy milyen módon implementálja a közösségi médiát a marketingtevékenységben a szervezet: 


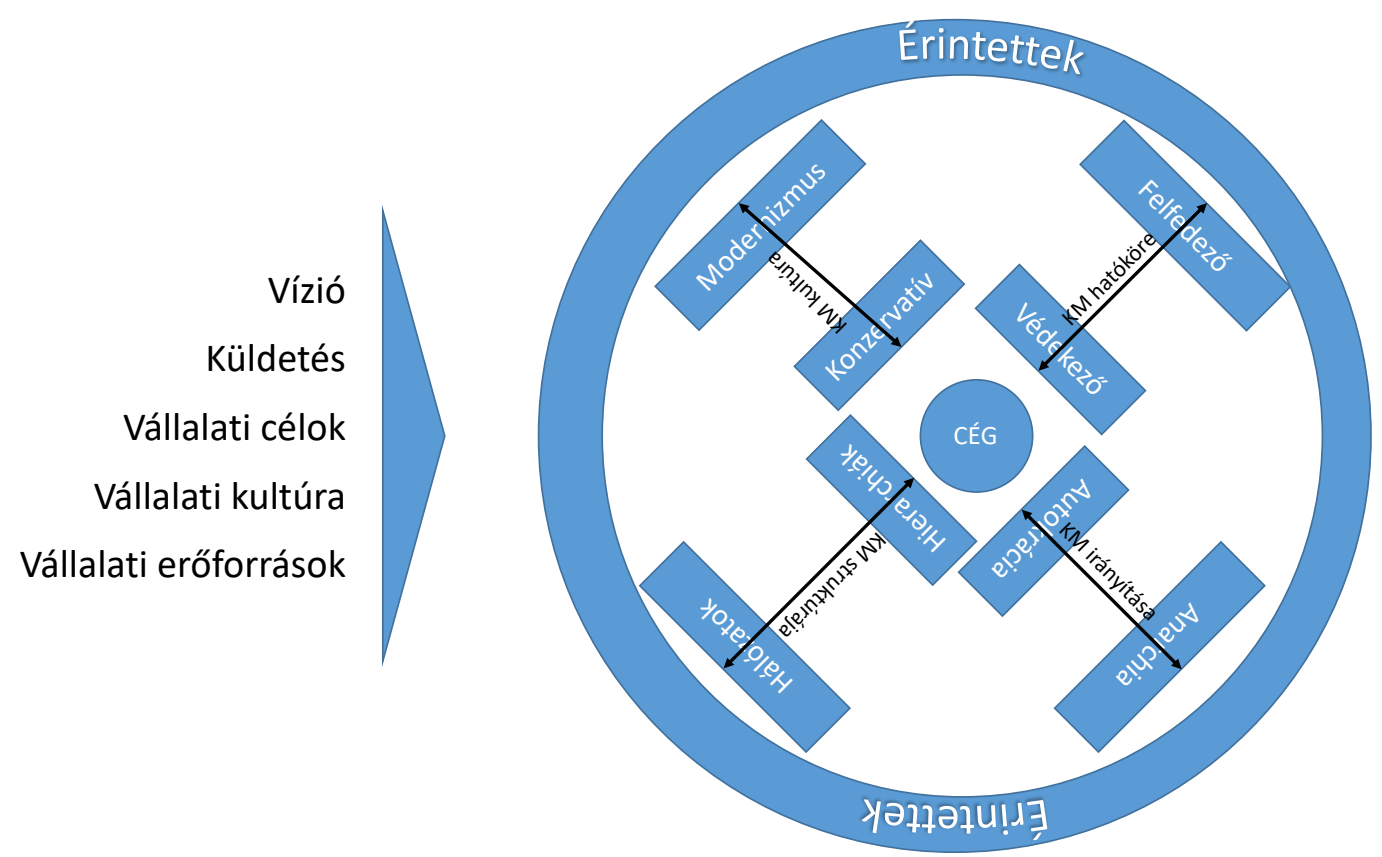

\section{Ábra 14: Közösségi média stratégiai használata}

Forrás: Felix et al. (2015), pp.4

A szerzők négy dimenziót azonosítottak, melyek a cég közösségi média használatát befolyásolják, ebböl három egyértelmüen a cég belső struktúrájához kötődik:

- belső struktúra, ami a hierarchikustól a hálózatos struktúráig terjedhet

- a kultúra, ami egy konzervatívtól a „modern-irányultság”-ig terjedő skálán helyezhető el

- és a vezetési stílus, melynek két szélső értéke az autokrácia illetve az anarchia.

A szerzők úgy értékelik: a belső valamint a külső tényezők összességében meghatározzák a cég választási lehetőségét, azt, hogy a közösségi médiát egy új típusú médiumként kezelve a vállalati müködés érintettjeivel való kapcsolatépítés eszközeként kezeli vagy pusztán egy újabb kommunikációs csatornaként tekint rá, melyen keresztül a vevőket információval „,bombázzák”.

Reynolds (2015) arra is ráirányítja a figyelmet: a folyamat kétirányú, nem csak az új típusú kommunikációs eszközök indukálnak szervezeti változásokat, de a szervezeti változások is eredményesebben vezényelhetőek le a közösségi média, mobil alkalmazások, stb használata révén. Ez viszont arra is figyelmeztet, hogy a 77 
szervezeti folyamatok valamint az alkalmazott technológiai megoldások változása ill. változatlansága különböző megközelítés módot igényel.

\subsection{Közösségi média alkalmazások tudás igénye}

A korábban már ismertetett Hoffman-Fodor (2011) tipológia szerint bemutatom, hogy a közösségi média alkalmazások

(1) milyen jellegzetességekkel bírnak, illetve ezeken a felületeken

(2) milyen típusú tudásra van szükség.

A választás azért esett a szerzőpáros tipológiájára, mivel az általuk felállított 8 kategória átfogóan lefedi azokat az alkalmazásokat, melyek az új média ma a legfontosabbaknak tartanak - marketing szempontokból is. 


\begin{tabular}{|c|c|c|c|c|c|c|}
\hline & Fö célcsoport ${ }^{8}$ & Alapvető hatás & Költség & $\begin{array}{l}\text { Erőforrás igény } \\
\text { a szervezet } \\
\text { részéről }\end{array}$ & Tartalom & $\begin{array}{l}\text { Egyéb média- } \\
\text { specifikus } \\
\text { jellemzők }\end{array}$ \\
\hline Blogok & $\begin{array}{l}\text { Közép korosztály } \\
(35-55) \text {; férfiak (e) }\end{array}$ & imázs / sales & Alacsony & $\begin{array}{l}\text { Szövegíró, } \\
\text { tartalom- } \\
\text { közösség } \\
\text { mendezser. } \\
\text { Induláshoz } \\
\text { informatika és } \\
\text { webdesign }\end{array}$ & $\begin{array}{l}\text { Alapvetően } \\
\text { szöveges, de } \\
\text { széles körü } \\
\text { lehetőség más, } \\
\text { multimédiás } \\
\text { tartalmak } \\
\text { elhelyezésére }\end{array}$ & $\begin{array}{l}\text { Bizonyos } \\
\text { blogszolgáltatók } \\
\text { domináns piaci } \\
\text { részesedéssel } \\
\text { bírnak (wordpress, } \\
\text { blogspot); vállalati } \\
\text { domain-en } \\
\text { futtatott blogok } \\
\text { hitelessége } \\
\text { fogyasztók } \\
\text { számára vitatott a } \\
\text { szakirodalmon } \\
\text { belül (f) }\end{array}$ \\
\hline
\end{tabular}




\begin{tabular}{|c|c|c|c|c|c|c|}
\hline & Fö célcsoport ${ }^{8}$ & Alapvető hatás & Költség & $\begin{array}{l}\text { Erőforrás igény } \\
\text { a szervezet } \\
\text { részéről }\end{array}$ & Tartalom & $\begin{array}{l}\text { Egyéb média- } \\
\text { specifikus } \\
\text { jellemzők }\end{array}$ \\
\hline Mikroblogok & $\begin{array}{l}\text { Fiatal korosztály } \\
(18-29) ; \quad A B \\
\text { jövedelmi státusz, } \\
\text { városias; } \\
\text { magasabb iskolai } \\
\text { végezettséggel (a) }\end{array}$ & imázs & Alacsony & $\begin{array}{l}\text { Szövegíró, } \\
\text { tartalom- } \\
\text { közösség } \\
\text { menedzser }\end{array}$ & $\begin{array}{l}\text { Főként szöveg, } \\
\text { minimális képi / } \\
\text { videó tartalommal }\end{array}$ & $\begin{array}{l}\text { Limitált szöveg, } \\
\text { egy kép vagy } \\
\text { videó, \#hashtag-ek } \\
\text { használata } \\
\text { széleskörűen } \\
\text { elterjedt }\end{array}$ \\
\hline
\end{tabular}

${ }^{8}$ A célcsoport meghatározásakor az egyes kategóriák átlagértékét vettük alapul. Ez bizonyos alkalmazásoknál jelentős diverzitást rejt: a blogok (akár csak az újságok, vagy a televízió csatornák a hagyományos médiumok esetében) például rendkívüli sokféleséget mutatnak, így a megjelölt célcsoporton felül gyakorlatilag minden más célcsoport elérésére is alkalmas tud lenni. Részben hasonló helyzet áll fenn a közösségi oldalak, valamint a videó- és fotó megosztó alkalmazások esetén is. 


\begin{tabular}{|c|c|c|c|c|c|c|}
\hline & Fö célcsoport ${ }^{8}$ & Alapvető hatás & Költség & $\begin{array}{l}\text { Erőforrás igény } \\
\text { a szervezet } \\
\text { részéről }\end{array}$ & Tartalom & $\begin{array}{l}\text { Egyéb média- } \\
\text { specifikus } \\
\text { jellemzők }\end{array}$ \\
\hline $\begin{array}{l}\text { Ko-kreációs } \\
\text { alkalmazások }\end{array}$ & $\begin{array}{l}\text { (vállalat } \\
\text { határozhatja meg) }\end{array}$ & sales & $\begin{array}{l}\text { Magas induló } \\
\text { költségek, } \\
\text { fenntartás } \\
\text { közepes } \\
\text { alacsony }\end{array}$ & $\begin{array}{l}\text { Mérnök } \\
\text { (alkalmazás } \\
\text { összekapcsolatása } \\
\text { termelési } \\
\text { folyamatokkal); } \\
\text { közösség } \\
\text { menedzser; } \\
\text { informatikus, } \\
\text { fejlesztő, } \\
\text { webdesigner }\end{array}$ & $\begin{array}{l}\text { Főként alkalmazás } \\
\text { (hangsúly a } \\
\text { használhatóságon) }\end{array}$ & $\begin{array}{l}\text { Nagy beruházás } \\
\text { igénye lehet, ami } \\
\text { az internetes } \\
\text { jelenléten felül a } \\
\text { teremlési és } \\
\text { logisztikai } \\
\text { folyamatok } \\
\text { átszervezését is } \\
\text { megkövetelheti; } \\
\text { Széleskörü } \\
\text { alkalmazási } \\
\text { lehetőség; Minden } \\
\text { megoldás egyedi } \\
\text { fejlesztés } \\
\text { eredménye }\end{array}$ \\
\hline
\end{tabular}




\begin{tabular}{|c|c|c|c|c|c|c|}
\hline & Fö célcsoport ${ }^{8}$ & Alapvető hatás & Költség & $\begin{array}{l}\text { Erőforrás igény } \\
\text { a szervezet } \\
\text { részéről }\end{array}$ & Tartalom & $\begin{array}{l}\text { Egyéb média- } \\
\text { specifikus } \\
\text { jellemzők }\end{array}$ \\
\hline $\begin{array}{l}\text { Közösségi } \\
\text { könyvjelzök }\end{array}$ & $\begin{array}{l}\text { Nők; alacsonyabb } \\
\text { iskolai végzettség; } \\
\text { idősebb } \\
\text { korosztályok } \\
\text { felülreprezentátak } \\
(55+) \text { (c) }\end{array}$ & - & Alacsony & $\begin{array}{l}\text { Közösségi } \\
\text { menedzser; }\end{array}$ & $\begin{array}{l}\text { Linkek, rövid } \\
\text { szöveges leírással }\end{array}$ & $\begin{array}{l}\text { Szerepük } \\
\text { korlátozott } \\
\text { vállalati } \\
\text { marketingben }\end{array}$ \\
\hline Fórumok & $\begin{array}{l}\text { (vállalat } \\
\text { célcsoportjától } \\
\text { függő) }\end{array}$ & $\begin{array}{l}\text { A fogyasztói } \\
\text { információ } \\
\text { szerzés fontos } \\
\text { terepe (h) (i); }\end{array}$ & Alacsony & $\begin{array}{l}\text { Közösség } \\
\text { menedzser; } \\
\text { informatikus; } \\
\text { webdesigner }\end{array}$ & $\begin{array}{l}\text { Föként szöveg, } \\
\text { kisebb részben } \\
\text { képek, videók }\end{array}$ & $\begin{array}{l}\text { Ritkábban } \\
\text { használt eszköz a } \\
\text { marketingen belül, } \\
\text { gyakran } \\
\text { fogyasztói } \\
\text { visszajelzések } \\
\text { begyüjtésére } \\
\text { valamint vevői } \\
\text { támogatásra } \\
\text { használják (j) }\end{array}$ \\
\hline
\end{tabular}




\begin{tabular}{|c|c|c|c|c|c|c|}
\hline & Fö célcsoport ${ }^{8}$ & Alapvető hatás & Költség & $\begin{array}{l}\text { Erőforrás igény } \\
\text { a szervezet } \\
\text { részéről }\end{array}$ & Tartalom & $\begin{array}{l}\text { Egyéb média- } \\
\text { specifikus } \\
\text { jellemzők }\end{array}$ \\
\hline $\begin{array}{l}\text { Termék értékelö } \\
\text { oldalak }\end{array}$ & $\begin{array}{l}\text { Fiatal és közép } \\
\text { korú korosztályok } \\
(18-49) \text {; magasabb } \\
\text { iskolai végzettség; } \\
\text { felső jövedelmi } \\
\text { kvartilis; városias } \\
\text { lakóhely (d) }\end{array}$ & sales & Alacsony & $\begin{array}{l}\text { Tartalom } \\
\text { menedzser; } \\
\text { bérkommentelő, } \\
\text { bérértékelő; }\end{array}$ & $\begin{array}{l}\text { Szöveg valamint } \\
\text { értékelés } \\
\text { igen / nem, stb) }\end{array}$ & $\begin{array}{l}\text { Vállalati } \\
\text { kontrollon kívül } \\
\text { eső terület, ami } \\
\text { alapvetően } \\
\text { meghatározhatja a } \\
\text { vásárlói döntést } \\
\text { (d); A cégek csak } \\
\text { szürke/fekete } \\
\text { eszközökkel } \\
\text { avatkozhatnak be } \\
\text { (bérkommentelők, } \\
\text { bérértékelők) } \\
\text { magas reputációs } \\
\text { kockázat } \\
\text { „lebukás” esetén }\end{array}$ \\
\hline
\end{tabular}




\begin{tabular}{|c|c|c|c|c|c|c|}
\hline & Fő célcsoport ${ }^{8}$ & Alapvető hatás & Költség & $\begin{array}{l}\text { Erőforrás igény } \\
\text { a szervezet } \\
\text { részéről }\end{array}$ & Tartalom & $\begin{array}{l}\text { Egyéb média- } \\
\text { specifikus } \\
\text { jellemzők }\end{array}$ \\
\hline $\begin{array}{l}\text { Közösségi } \\
\text { hálózatok }\end{array}$ & $\begin{array}{l}\text { Fiatalabb és } \\
\text { középkorú } \\
\text { korosztály (18- } \\
49) \text {; változatos } \\
\text { jövedelmi státusz } \\
\text { (minden } \\
\text { szegmensböl); } \\
\text { lakóhely, nem, } \\
\text { iskolai végzettség } \\
\text { szerint indifferens } \\
\text { (a) }\end{array}$ & $\begin{array}{l}\text { imázs (ritkábban: } \\
\text { sales) }\end{array}$ & Közepes / magas & $\begin{array}{l}\text { Tartalom és } \\
\text { közösség } \\
\text { menedzser; } \\
\text { szövegíró; } \\
\text { képszerkesztő / } \\
\text { grafikus; hirdetés } \\
\text { menedzser / költés } \\
\text { kezelő }\end{array}$ & $\begin{array}{l}\text { Saját } \\
\text { alkalmazások } \\
\text { (applikációk), } \\
\text { szöveg, kép, videó }\end{array}$ & $\begin{array}{l}\text { A fogyasztók } \\
\text { érdeklődését } \\
\text { föként a vizuális } \\
\text { elemek keltik fel, a } \\
\text { fogyasztók } \\
\text { megszerzése } \\
\text { valamint ismételt } \\
\text { elérése gyorsan } \\
\text { meg tudja dobni a } \\
\text { költségeket }\end{array}$ \\
\hline
\end{tabular}




\begin{tabular}{|c|c|c|c|c|c|c|}
\hline & Fö célcsoport ${ }^{8}$ & Alapvető hatás & Költség & $\begin{array}{l}\text { Erőforrás igény } \\
\text { a szervezet } \\
\text { részéről }\end{array}$ & Tartalom & $\begin{array}{l}\text { Egyéb média- } \\
\text { specifikus } \\
\text { jellemzők }\end{array}$ \\
\hline $\begin{array}{l}\text { Videó- és fotó } \\
\text { megosztó } \\
\text { alkalmazások }\end{array}$ & $\begin{array}{l}\text { Nők; tinédzserek } \\
(13-17) \text { valamint } \\
\text { fiatal korosztályok } \\
(18-29) \text {; felsőbb } \\
\text { jövedelmi } \\
\text { szegmensek (b) } \\
\text { (g) }\end{array}$ & imázs & $\begin{array}{l}\text { Alacsony } \\
\text { közepes }\end{array}$ & $\begin{array}{l}\text { Képszerkesztő; } \\
\text { tartalom és } \\
\text { közösség } \\
\text { menedzser; } \\
\text { esetleg operatőr, } \\
\text { vágó, rendező, } \\
\text { stáb }\end{array}$ & $\begin{array}{l}\text { Videó, kép, rövid } \\
\text { szöveges leírással, } \\
\text { valamint ezek } \\
\text { fölött létrehozott, } \\
\text { kattintható layerek }\end{array}$ & $\begin{array}{l}\text { A költség a } \\
\text { hirdetés } \\
\text { intenzitásától, } \\
\text { valamint az } \\
\text { elöállított tartalom } \\
\text { típusától függ }\end{array}$ \\
\hline
\end{tabular}

\section{Táblázat 15: A közösségi média alkalmazások reklámstratégiai szempontjai}

Forrás: a) Duggan et al., 2015; b) Lenhard, 2015; c) www.alexa.com, 2015; d) Jansen, 2010; e) pingdom.com, 2013; f) Lee et al. 2006; g)

Guimaraes, 2014; h) Bickart-Schindler, 2001; i) Chiou-Cheng, 2003; j) Nambisan-Watt, 2011 


\section{Kihívások a marketing számára}

Egyes szerzők szerint a közösségi média és más diszruptív technológiák „az általunk ismert marketing végét jelentik" (Hamill, 2017). Mások kevésbé drámai hangot ütnek meg, de abban nincs vita, hogy a közösségi média és a várhatóan a közel jövőbe elterjedö, új technológiák (kiterjesztett valóság, robotika, ,internet of things", ember-számítógép interfész, stb) nem csak új lehetőségeket, de ezzel együtt új kihívásokat is tartogat a gyakorló marketing szakemberek és az akadémiai kutatók számára is. Ezek a kihívások alapvetően két kategóriába sorolhatóak: egy részük a közösségi média marketing célú implementációjával, lehetőségeivel van összefüggésben, ez jellemzően a cégek belső folyamatait érintik. A másik részük a közösségi média által megváltoztatott környezeti feltételeknek és viszonyoknak „köszönhetö”, ez pedig a vállalat és környezet viszonyát érinti. Mint láttuk például, a vállalatok határai elmosódnak, az önálló müködés helyett ökoszisztémaszerü szimbiózisban élnek a cégek és a különbözö ügynökségek, stb.

Az IBM egy 2011-es, marketingvezetők (CMO) megkérdezésén alapuló kutatásában mind a két kategória megjelenik. Ebben az elkövetkező évek 4 fontos kihívását azonosították be: (1) elérhető adatok méretének exponenciális ütemü bővülése (,big data”) (2) közösségi média menedzselése (3) csatorna és eszköz választás és (4) fogyasztók demográfiai adatainak változása. Látható: a négy kihívás közül három közvetlenül is kapcsolatban áll az új médiával. Choi-Thoeni (2016) kifejezetten a közösségi média marketing sikeres szervezeti implementációjának vállalaton belüli feltételrendszerét vizsgálta. Kutatásuk alapján a felső vezetés stratégiai és operatív támogatása, vertikális koordináció, a közösségi média és az általános marketing stratégia összhangjának megteremtése, a versenytársak monitorozása valamint a felhasználókkal való kapcsolat egyes paraméterei (megfigyelés, válaszadás, interakció) a siker kulcstényezői.

Leeflang és szerzőtársai 10 olyan feszültségforrást azonosítottak be, amelyekre a vállalatoknak reagálniuk kell, ahogy a digitális média növekvő módon van jelen a mindennapjainkban: 


\begin{tabular}{|c|c|c|}
\hline Feszültség & Kihívás & Leírás \\
\hline $\begin{array}{l}\text { Digitális } \\
\text { forradalom }\end{array}$ & $\begin{array}{l}\text { Támogat } \\
\text { védekezik }\end{array}$ & $\begin{array}{l}\text { A digitális média térnyerése a } \\
\text { meglevő üzleti modelleket } \\
\text { fenyegeti }\end{array}$ \\
\hline Fogyasztói belátás & $\begin{array}{l}\text { Megkülönböztető } \\
\text { előny vagy higiéniai } \\
\text { faktor }\end{array}$ & $\begin{array}{l}\text { Gazdag és döntéstámogatásra } \\
\text { alkalmas fogyasztói belátások } \\
\text { generálása ma a versenyben } \\
\text { maradás feltétele }\end{array}$ \\
\hline Áttörés & $\begin{array}{l}\text { Adatok feldolgozása } \\
\text { vagy kreativitás }\end{array}$ & $\begin{array}{l}\text { A túlzott adatfüggőség a kreativitás } \\
\text { és az áttörő innováció akadálya } \\
\text { lehet }\end{array}$ \\
\hline Közösségi média & $\begin{array}{l}\text { Vevői elkötelezés } \\
\text { vagy a vevők } \\
\text { felbosszantása }\end{array}$ & $\begin{array}{l}\text { A márkák és vállalati reputáció } \\
\text { menedzselése nehezebb olyan } \\
\text { környezetben, ahol a közösségi } \\
\text { média fontos szerepet játszik }\end{array}$ \\
\hline Online lehetőségek & $\begin{array}{l}\text { Fiatalok vs. „mi, } \\
\text { többiek” }\end{array}$ & $\begin{array}{l}\text { Az online kampányok jelentös } \\
\text { része kizárólag fiatal } \\
\text { célközönségre fókuszál, kihagyva } \\
\text { az idősebb (de ígéretes) } \\
\text { célcsoportokat }\end{array}$ \\
\hline $\begin{array}{l}\text { Árazási } \\
\text { transzparencia }\end{array}$ & $\begin{array}{l}\text { Szabadon enged } \\
\text { vagy kontroll alatt } \\
\text { tart }\end{array}$ & $\begin{array}{l}\text { Az online árösszehasonlító oldalak } \\
\text { veszélyeztetik a vállalatok } \\
\text { optimális ár meghatározására való } \\
\text { képességét }\end{array}$ \\
\hline $\begin{array}{l}\text { Automatizált } \\
\text { interakció }\end{array}$ & $\begin{array}{l}\text { Produktív } \\
\text { romboló }\end{array}$ & $\begin{array}{l}\text { Szolgáltatás automatizálás } \\
\text { valamint a vevők online csatornára } \\
\text { való terelése } \\
\text { elégedetlenséghez vevői } \\
\text { (értékrombolás) }\end{array}$ \\
\hline
\end{tabular}




\begin{tabular}{|c|c|c|}
\hline Feszültség & Kihívás & Leírás \\
\hline Mérés & $\begin{array}{l}\text { Expanzió } \\
\text { tradíció }\end{array}$ & $\begin{array}{l}\text { Online mérőszámok alkalmazása } \\
\text { (beillesztése) nehéz, mivel nem } \\
\text { (azonnal) kompatibilisek a már } \\
\text { meglevő mérőszámokkal }\end{array}$ \\
\hline Tehetség hiány & $\begin{array}{l}\text { Inkrementális } \\
\text { változás vagy } \\
\text { alapvető átalakítás }\end{array}$ & $\begin{array}{l}\text { A marketing (és kapcsolódó) } \\
\text { szervezetek komoly tehetség } \\
\text { hiánnyal néznek szembe }\end{array}$ \\
\hline Szervezet & $\begin{array}{l}\text { Funkcionális vagy } \\
\text { integratív }\end{array}$ & $\begin{array}{l}\text { A marketing feladatok bővülése a } \\
\text { szervezeten belül feszültségekhez } \\
\text { vezet (pl. szerepzavar, nem } \\
\text { tisztázott felelősségi körök és } \\
\text { ösztönzők) }\end{array}$ \\
\hline
\end{tabular}

Táblázat 16: A közösségi média által generált feszültségforrások

Forrás: Leeflang et al. (2014), p4.

A szerzők az általuk felvázolt tíz problémát ábrázolták a megoldás nehézségének, valamint a már meglevő „tervek” (megoldási javaslatok) készültségi fokának függvényében. Az ábrából következtetni lehet arra is, hogy az adott terület megoldásával milyen fokú előnyre lehet szert tenni. 


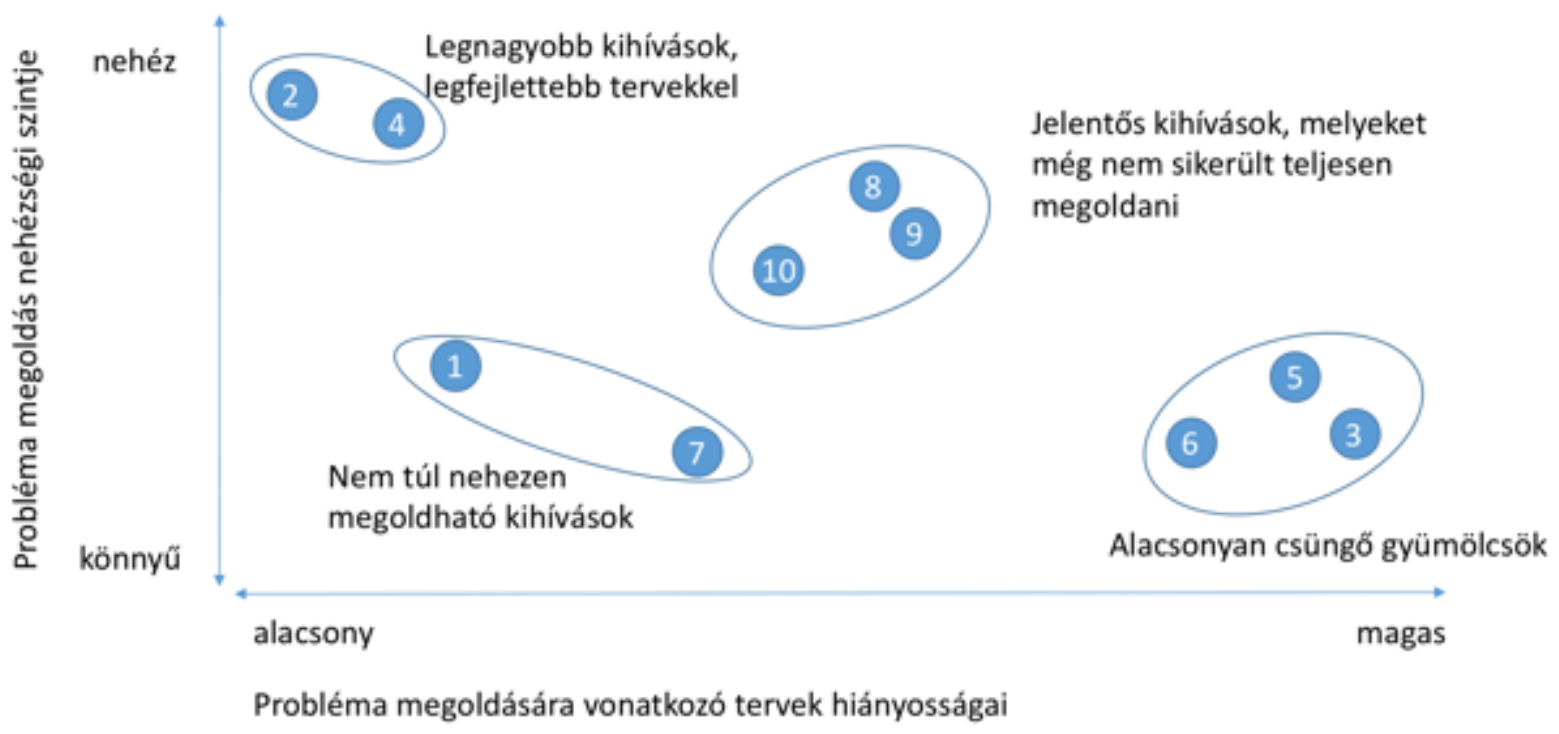

\begin{abstract}
Ábra 15: Közösségi média kihívások
Forrás: Leeflang et al. (2014) p5. A számok a korábban bemutatott feszültségeket jelentik, az alábbiak szerint: (1) digitális forradalom, (2) fogyasztói belátás, (3) áttörés, (4) közösségi média, (5) online lehetőségek, (6) árazási transzparencia, (7) automatizált interakció, (8) mérés, (9) tehetség hiány, (10) szervezet
\end{abstract}

A szerzők a fenti probléma-lehetőség mátrixban a szervezeti kérdéseket olyan jelentős kihívásként mutatják be, melyekre -egyelőre- nincsenek elfogadott válaszok. Érvelésük szerint a felmerült képességbeli hiányosságok áthidalására a külső partnerek (ügynökségek) bevonása lehet egy járható út. A személyi képességek, tehetségek bevonzásán túl a szervezeti felépítést is mérlegelték a szerzők. Megítélésük a korábban bemutatott eredményekkel összhangban azt állítja, hogy a digitális marketing alkalmazási feltétele a korábbiaktól eltérő szervezeti struktúra kialakítása. A kérdés élét az is adja, hogy a szakirodalomban részletesen kutatott és feltárt területnek nevezhető a funkcióközi koordináció problémái a marketing és más szervezeti egységek (pl. értékesítés, pénzügy, stb.) relációjában.

\title{
A magyar piac sajátosságai
}

A dolgozat következő fejezetében ismertetett kutatások Magyarországon müködő cégek vezetőinek megkérdezésével, itt tevékenykedő vállalatok adatbázisainak a 
felhasználásával készültek. Érdemes tehát megvizsgálni, hogy az ország milyen módon tér el a nemzetközi „átlagtól”, melyek akár a kutatási eredményeket, azok értelmezését is befolyásolhatják illetve azok korlátját is jelenthetik. A téma szempontjából Magyarország három fontos jellemvonását vizsgáltam: (1) a „hightech”-kel való viszony, (2) gazdasági strukturális jellemzői, valamint (3) hasonló paraméterekkel rendelkező országokkal való összevetésben.

Magyarország az Európai Unió többi tagállamával való összevetésben közepesen fejlett az online technológiákkal való ellátottság illetve azok használata terén. Ennek az állításnak a bizonyítására az Eurostat legfrissebben elérhető, 2018-as adatbázisból ${ }^{9}$ több mutatót vizsgálok meg:

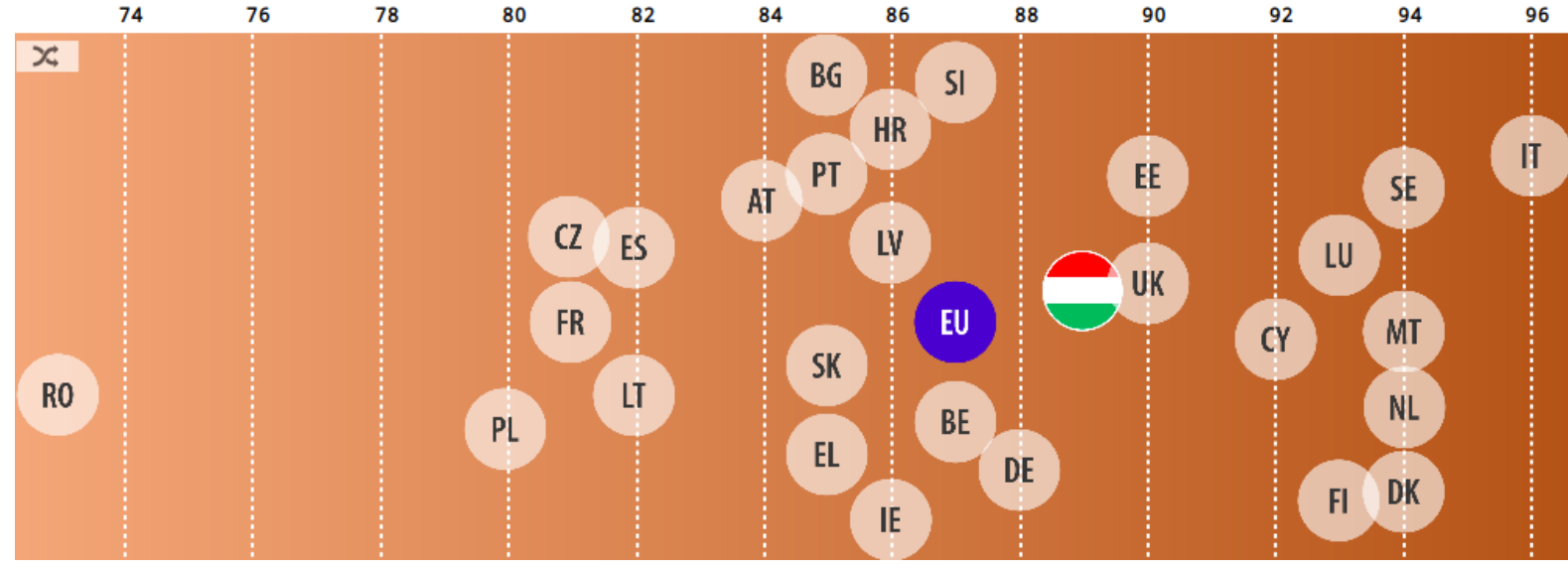

\section{Ábra 16: „Napi internethasználók” Európában ${ }^{10}$}

Forrás: Eurostat, 2018

${ }^{9}$ Az adatok forrása az Eurostat Digital economy \& society in the EU, 2018 edition évkönyv. Elérhetö: http://ec.europa.eu/eurostat/cache/infographs/ict/2018/index.html

${ }^{10}$ Azoknak a lakosoknak az aránya, akik az elmúlt 3 hónapban csatlakoztak az internetre 


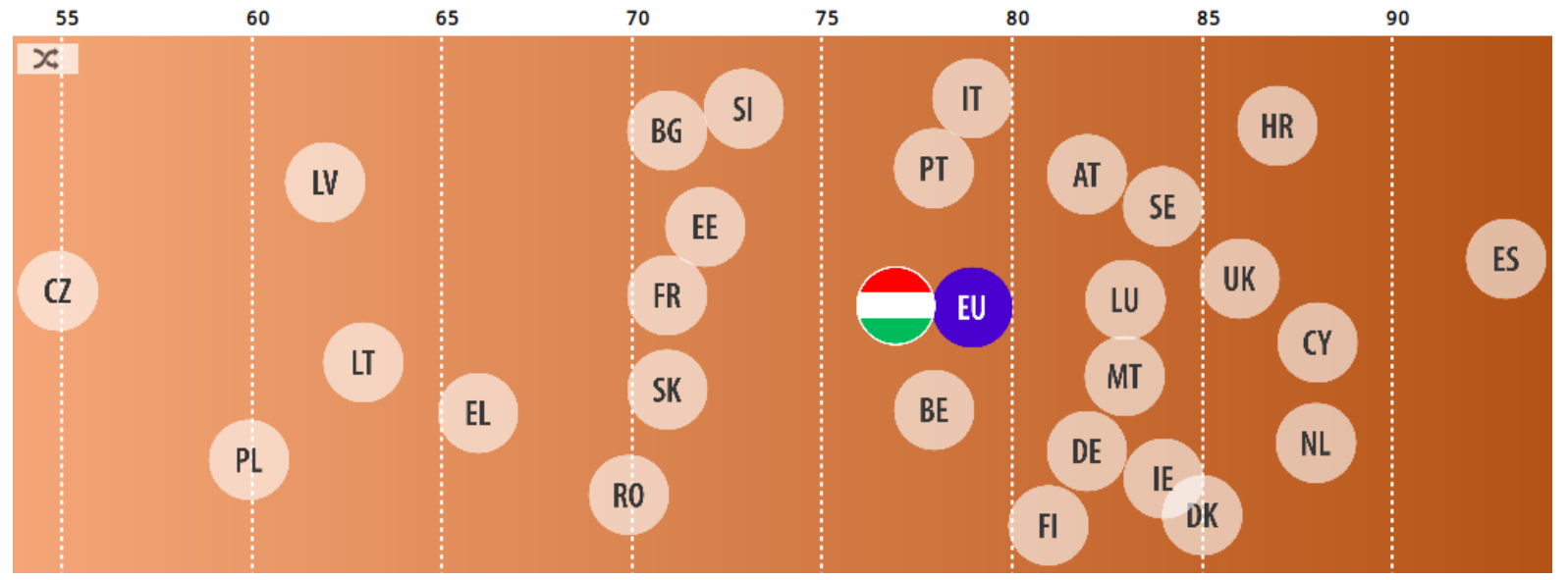

\section{Ábra 17:,Mobil internethasználók” Európában"11}

Forrás: Eurostat, 2018

Magyarország semmilyen mutató tekintetében nem tartozik sem az élbolyba, de a leszakadók táborában sincsen. Az Európa digitális fejlődéséről szóló jelentésben a Magyarországról alkotott országprofil az ország digitális fejlettségét valamint a digitális technológiák társadalmi, kormányzati és gazdasági beágyazottságát vizsgáló komplex mutatószámrendszer alapján a fentinél kedvezőtlenebb kép rajzolódik ki, Magyarország a gyengén teljesítő országok közé tartozik:

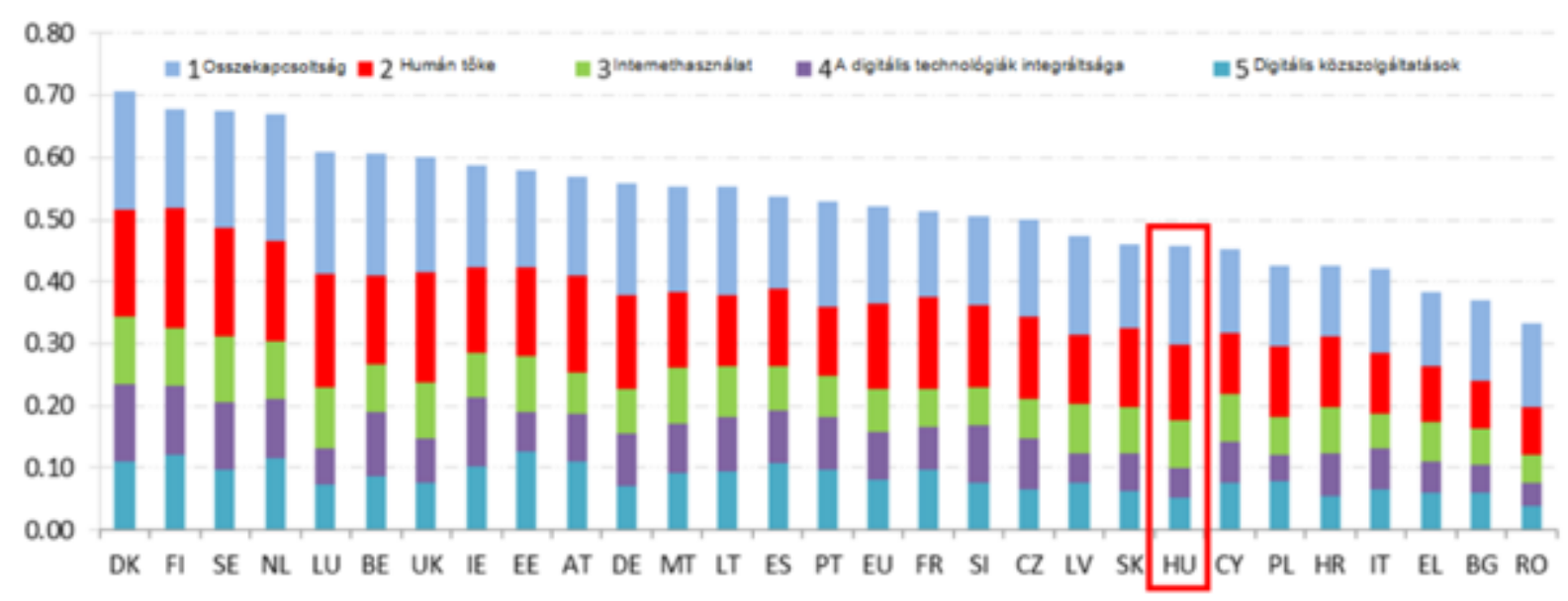

Ábra 18: A digitális gazdaság és társadalom fejlettségét mérő mutató (DESI) - 2017-es helyezések

11 Azoknak a lakosoknak az aránya, akik az elmúlt 3 hónapban mobiltelefon használatával csatlakoztak az internetre. 
Forrás: https://ec.europa.eu/digital-single-market/en/scoreboard/hungary

A jelentés a lemaradás okaként azt jelöli meg, hogy az üzleti szektor nem használja ki más országokhoz hasonló mértékben a digitális technológia által nyújtott lehetőségeke. Emellett a közszolgáltatások elektronikus nyújtásának kisebb mértékü fejlesztései ellenére Magyarország a 27. helyet foglalja el a listán. Ráadásul több kulcsmutató szempontjából az ország abszolút és/vagy relatív értelemben is romlást ért el az előző évhez mérten.
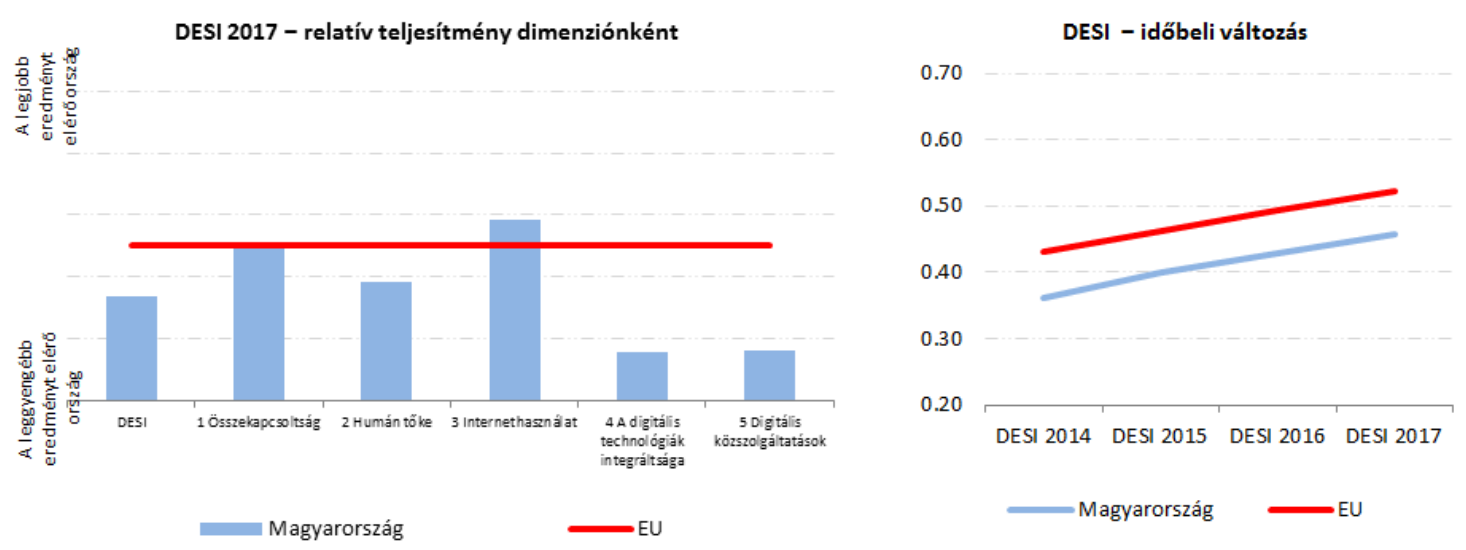

Ábra 19: A DESI mutató relatív teljesítmény valamint időbeli megbontása Forrás: https://ec.europa.eu/digital-single-market/en/scoreboard/hungary

Az uniós adatok alapján ez a vállalatok internetes teljesítményére is hatással van. Online értékesítéssel rendelkező cégek arány, valamint a cégek teljes forgalmán belül a webes értékesítés aránya is uniós átlag alatti Magyarországon:

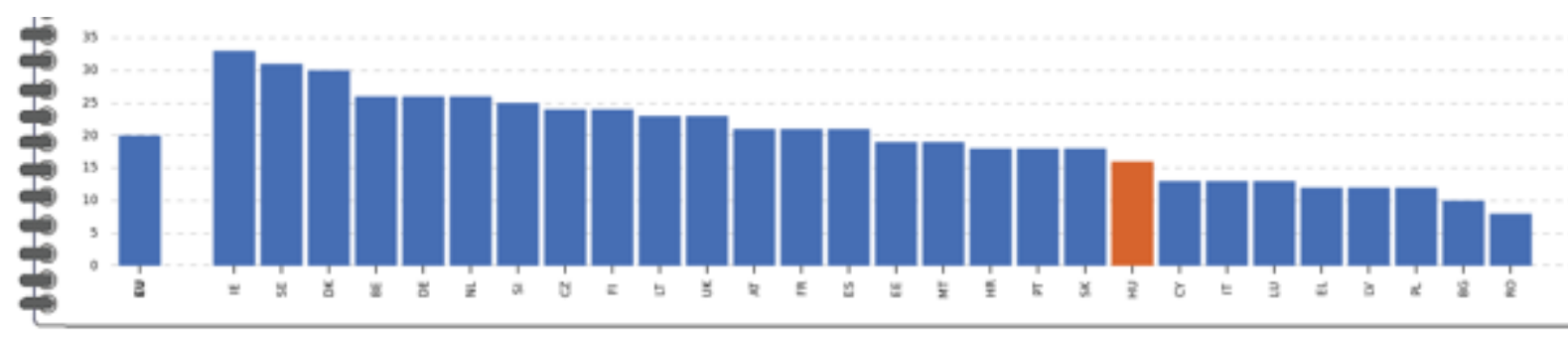

\footnotetext{
Ábra 20: Elektronikus csatornán értékesítő vállalatok aránya az EU egyes tagállamaiban

Forrás: Eurostat, 2017. http://ec.europa.eu/eurostat/web/products-eurostat-news/$\underline{\text { DDN-20170713-1 }}$
} 
Ábra 21: A webes forgalom aránya a teljes forgalom százalékában az EU egyes tagállamaiban

Forrás: Eurostat, 2017. http://ec.europa.eu/eurostat/web/products-eurostat-news/$\underline{\text { DDN-20170713-1 }}$

A közösségi média használat terén ugyanakkor az EU-s környezetben abszolút kiemelkedő az ország:

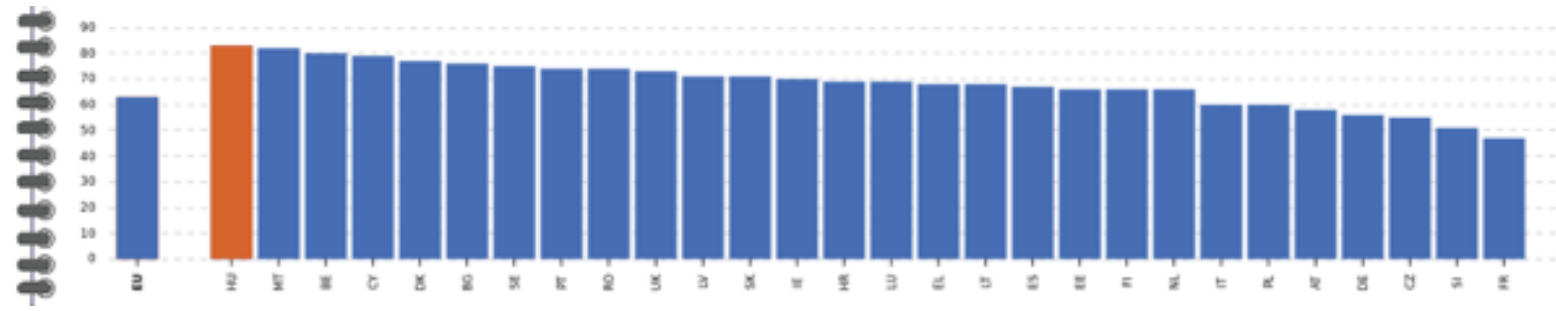

Ábra 22: Közösségi média oldalak felhasználóinak aránya azok körében, akik az elmúlt 3 hónapban használták az internetet

Forrás: Eurostat, 2017. http://ec.europa.eu/eurostat/web/products-eurostat-news/(DDN-20170713-1 ).

Ez a megállapítás egy másik adattal párosítva még többet árul el a hazai felhasználókról. Magyarországon a világszerte elterjedt közösségi média oldalak közül csupán néhány nagyobbnak sikerült az ország viszonylataiban jelentős, több százezres felhasználói tábort toboroznia (Facebook, YouTube, Snapchat, Instagram). Olyan világszinten jelentős szereplők hiányoznak a palettáról, mint például a Twitter. De azok a közösségi média oldalak, amelyek jelen vannak, az ország lakosságának jelentős hányadát tudhatják felhasználóik között. A Facebookon például a magyar állampolgárok 54,15 százaléka volt regisztrálva 2017-es adatok szerint.

Hágen és Holló (2017) alapján a magyar gazdaságban a vállalkozási formák aránya az uniós átlagnak felel meg, ugyanakkor a KKV szektor az átlagosnál valamivel 93 
több alkalmazottat foglalkoztat (különösen a mikro-vállalkozások), míg gazdaság egészéhez hozzáadott értékben a nagyvállalkozások teljesítenek jobban. A két adat arra utal, hogy a kisebb cégek az átlagosnál kevésbé hatékonyan képesek a munkavállalókat alkalmazni.

\begin{tabular}{|c|c|c|c|c|c|c|c|c|c|}
\hline \multirow{3}{*}{ Megnevezés } & \multicolumn{3}{|c|}{ Vállalkozások száma } & \multicolumn{3}{|c|}{ Foglalkoztatottak száma } & \multicolumn{3}{|c|}{ Hozzáadott érték } \\
\hline & \multicolumn{2}{|c|}{ Magyarország } & \multirow{2}{*}{$\begin{array}{l}\text { EU-28 } \\
\text { Arány }\end{array}$} & \multicolumn{2}{|c|}{ Magyarország } & \multirow{2}{*}{$\begin{array}{l}\text { EU-28 } \\
\text { Arány }\end{array}$} & \multicolumn{2}{|c|}{ Magyarország } & \multirow{2}{*}{$\begin{array}{l}\text { EU-28 } \\
\text { Arány }\end{array}$} \\
\hline & Menny. & Arány & & Menny. & Arány & & Milliárd € & Arány & \\
\hline Mikro-vállalkozások & 478021 & $94,2 \%$ & $92,7 \%$ & 847890 & $34,6 \%$ & $29,2 \%$ & 9 & $18,7 \%$ & $21,1 \%$ \\
\hline Kisvállalkozások & 24617 & $4,9 \%$ & $6,1 \%$ & 461790 & $18,8 \%$ & $20,4 \%$ & 8 & $16,1 \%$ & $18,2 \%$ \\
\hline Középvállalkozások & 4039 & $0,8 \%$ & $1,0 \%$ & 400148 & $16,3 \%$ & $17,3 \%$ & 9 & $18,8 \%$ & $18,5 \%$ \\
\hline$K K V-k$ & 506677 & $99,8 \%$ & $99,8 \%$ & 1709918 & $69,8 \%$ & $66,9 \%$ & 26 & $53,6 \%$ & $57,8 \%$ \\
\hline Nagyvállalkozások & 867 & $0,2 \%$ & $0,2 \%$ & 741405 & $30,2 \%$ & $33,1 \%$ & 23 & $46,4 \%$ & $42,2 \%$ \\
\hline Összesen & 507544 & $100,0 \%$ & $100,0 \%$ & 2451323 & $100,0 \%$ & $100,0 \%$ & 49 & $100,0 \%$ & $100,0 \%$ \\
\hline
\end{tabular}

Táblázat 17: A magyarországi és az európai KKV-k jellemzői

Forrás: Hágen-Holló (2017), pp.2.

Egyéb következményei is vannak annak, hogy a KKV-k jelentős aránya a gazdaság egészén belül. Ez a szektor jellemzően kevésbé tőkeerős, kevesebb pénzügyi és egyéb forrással bír, így az olyan marketing innovációkba is kevésbé képes befektetni, mint a közösségi média

A nagyvállalkozások is mást takarnak, mint a nyugati országokban. Magyarországon kevés központ üzemel, jellemzően összeszerelő mühelyek illetve shared service centerek találhatóak az országban. Ez azt is jelenti, hogy valódi döntéshozók külföldi központokban ülnek, az ott meghozott stratégiai döntések alapján a hazai menedzsment feladata jobbára azok operatív végrehajtásában merül ki. A nagyobb marketingfejlesztéseket ezek a cégek a vezető piacaikra koncentrálják, így a magyar marketing közösség több éves lemaradással követheti a fejlettebb országok trendjeit. Erre utal Szerb (2017) kutatása is, amely szerint a hazai vállalkozásoknak leginkább az innovációra, vevőkkel való kapcsolat erősítésére kell fókuszálniuk a versenyhelyzet javítása érdekében.

Végül kiemelésre méltó még, hogy más kis országok másak. A fenti uniós összehasonlításban is látszott, hogy olyan kisebb országok, mint Finnország, Észtország vagy Írország a technológiai fejlettség valamint a technológiai megoldások társadalmi-gazdasági beágyazott terén jelentősen megelőzik Magyarországot. Írország a kedvező helyzetét, társadalmi adottságait (pl. angol 94 
nyelv használata, adózási rendszer, stb) ki tudta használni arra, hogy az országba csábítsa több amerikai IT cég európai központját. 


\section{Empirikus kutatás}

\section{Kutatás módszer}

\subsection{A kutatás célja}

Az megelőző fejezetben tett szakirodalmi áttekintés alapján jelen dolgozat célja, hogy mélyebb belátást adjon azokba a szervezeti folyamatokba, melyeket a marketingosztályok életében a közösségi média térnyerése kényszerített ki. A vizsgálat fókuszában a marketingszervezet és annak vállalaton belüli valamint azon kívül álló partnerei állnak, akik a közös értékalkotás (vagyis a szervezeti marketing célok realizálása érdekében) egymással összehangolt stratégiát valósítanak meg. Ennek a komplex és a fentiekben bemutatott, egymással interdependens faktorokból álló kérdéskörnek a feltárása érdekében több oldalról vizsgáltam meg, vegyes módszertant alkalmazva.

A disszertáció fő kutatási kérdése az, hogy milyen szervezeti változásokkal követik le a magyar piacon tevékenykedő vállalatok a közösségi média által indukált változásokat.

A kutatás számos ponton csatlakozik a megelőző tudományos munkákhoz, elsősorban a közösségi média marketing, valamint szervezetelméleti alapokon. A cél az, hogy az elméleti áttekintésben megtett szakirodalmi szintézis alapjaira építkezve a kutatás legalább részlegesen betöltse a korábbiakban beazonosított szakirodalmi ürt, valamint hozzájáruljon a marketing szervezetek ökoszisztéma szerü müködésének az ebbe az irányba ható átalakulásnak a pontosabb megértéséhez. További tudományos cél, hogy elsősorban szervezeti oldalról megközelítve jelen kutatás segítse a közösségi média diszruptív hatásainak a feltérképezését.

A kutatás gyakorló menedzserek számára is hasznos tanulságokat fogalmaz meg, segíti a vállalati döntéshozatalt a témában tapasztalt bizonytalanság csökkentésével illetve olyan fogódzkodópontok feltárásával, melyek segítséget jelenthetnek a működő szervezetek átalakításának komplex folyamatában. 96 
A kutatás fentebb ismertetett céljaival összhangban több kutatási kérdés is megfogalmazásra került, melyek a következő fejezetben részletesen is bemutatásra kerülnek. Jelen disszertáció - témájánál fogva - feltáró kutatás. A kutatási kérdésekhez kapcsolódva ennek megfelelően nem lettek elvárások megfogalmazva a disszertációnak nem célja kvantitatív eszközökkel történő hipotézistesztelés.

\subsection{Kutatási kérdések}

A dolgozat fogalmi keretét a szakirodalmi áttekintésben vázolt elméleti csomópontok mentén az alábbiak szerint lehet felvázolni:

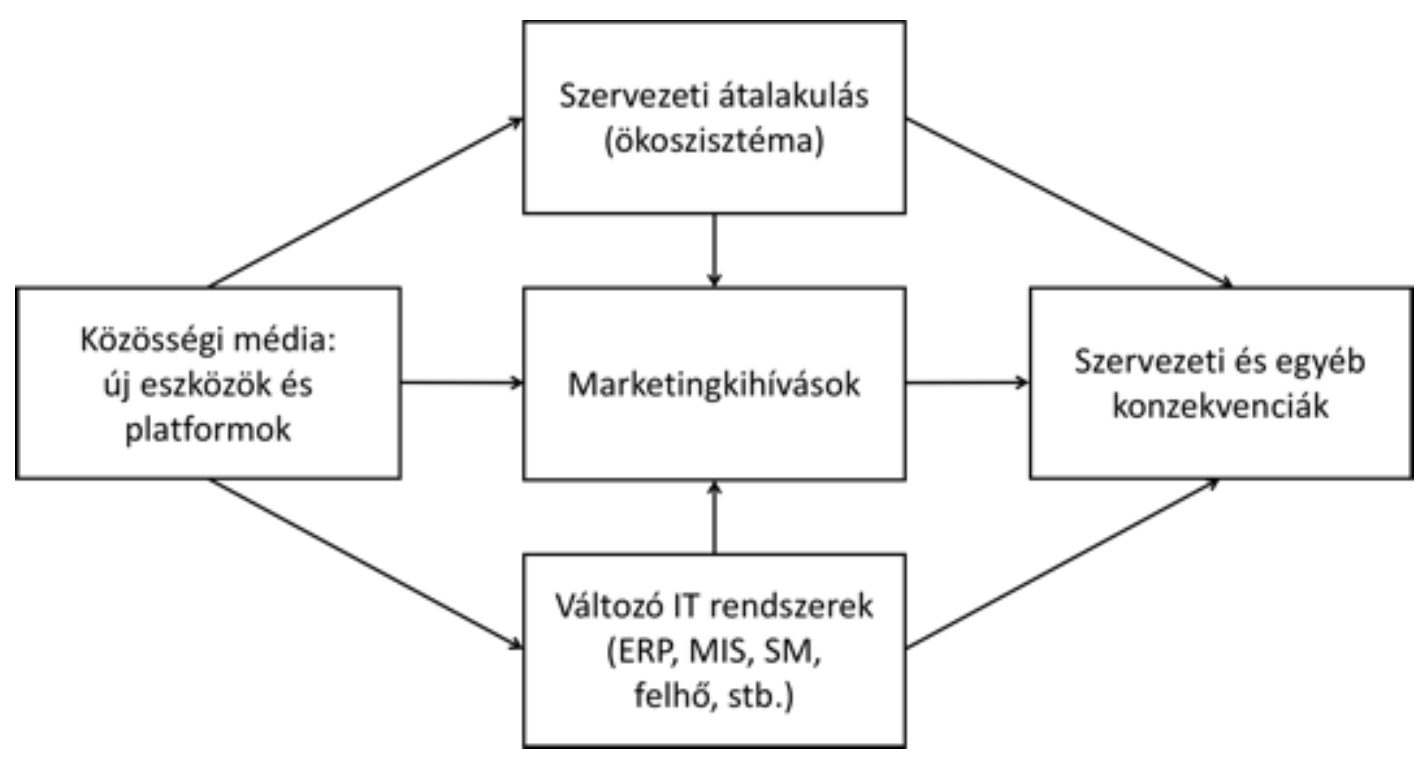

\section{Ábra 23: A kutatás fogalmi kerete}

Forrás: saját szerkesztés

A szakirodalmi áttekintésre valamint a fenti fogalmi keretre támaszkodva az empirikus kutatás célja az alábbi kérdések megválaszolása:

\section{RQ1. Milyen adaptációs stratégiával válaszolnak a marketingszervezetek arra} a környezeti kihívásra, amelyet közösségi média megjelenése, terjedése jelent?

A szakirodalmi áttekintés alapján leszögezhető: a közösségi média megjelenése alapvetően alakította át a vállalatok és fogyasztók kapcsolatát (O’Reilly, 2005; Kaplan-Haenlein, 2010; Dahl, 2018; stb) valamint a közöttük folyó kommunikáció természetét (pl. Mangold-Faulds, 2009; Markos-Kujbus, 2016). Ezek 97 
hagyományosan olyan vállalati feladatok, melyek irányítása a marketingszervezet kezébe tartozik. A megelőző kutatások áttekintése révén feltártunk 8 olyan vállalati területet, amelyet vagy közvetlenül a marketing irányítása alatt állnak vagy ennek az osztálynak ráhatása van azokra - és amelyeket közvetlenül is érint a közösségi média (ld. 7. táblázat). Már ennek alapján is kimutatható az, hogy az átalakulás a marketingosztály szervezeten belül elfoglalt pozícióját és azon kívüli kapcsolatait is befolyásolja (Murthy-Lewis, 2015), eltérő mértékben és más-más irányok mentén. Megállapítható, hogy a közösségi média sok szempontból gyökeresen eltér a hagyományos médiától (ld. 15. táblázat, Hoffman-Fodor, 2010).

Valószínűsíthető, hogy a válaszreakciókban jelentős eltérés figyelhető meg az egyes vállalatok között. A kutatásnak egy célja ezeknek az eltérőségeknek a felderítése, de nem célozza teljes, mindenre kiterjedő, átfogó kép felvázolását. Iparági eltérések mellett feltehető, hogy a vállalat mérete, tulajdonosi struktúrája, a versenyben elfoglalt pozíciója, valamint a piac más jellemzői is befolyásolhatják a vállalatok által adott válaszokat.

\section{RQ2. Milyen típusú kihívásokkal kell megküzdeniük a marketingosztályoknak a közösségi média implementációjában a magyar piacon?}

A közösségi média IT területről induló, de hatásaiban azon messze túlmutató társadalmi jelenség (Constantinides-Fountain, 2008), olyan decentralizált modell, ahol a hálózati csomópontok szaporodásával annak bonyolultsága is növekedésnek indult (Fehér, 2012). A közösségi hálózatok informatikai háttere miatt kézenfekvő ötlet, hogy a problémát a menedzsment információs rendszerek irányából közelítsük meg. Az ERP/MIS rendszerek bevezetésekor (kb '80-as évektől) jelentős szervezeti tudás és tapasztalat halmozódott föl informatikai rendszerek bevezetéséröl (Dedrick et al., 2003; Henderson-Venkatramn, 1993; Hong-Kim, 2002; stb). A számos azonos vonás mellett azonban jelentős különbségek is láthatóak a „hagyományos” IT rendszerek, valamint a közösségi média vállalati alkalmazása között (ld. 13. táblázat). 
A marketingosztályok struktúráját és külső szereplőkkel való kapcsolatát érintő változások vizsgálatában a szervezetelméleti szakirodalomból merítettem fogódzkodó pontokat. A hagyományos, mintzbergi modellben a marketingszervezet felépítése vizsgálható (Bauer-Berács, 2016; Antal, 2006), a közösségi média környezeti elemnek tekinthető - ez a megközelítés azonban nem magyarázza a közösségi média tudás elhalmozásának és disszeminációjának dinamikus folyamatát, és azt is csak részben, hogy miként és miért alakítja át a reklámiparágat ez az új csatorna.

\section{RQ3. A közösségi média sikeres implementációjához a vállalatoknak milyen új marketing képességek megszerzésére van szükségük?}

A marketing képességek Vorhies és Morgan (2008) értelmezésében a vállalati marketingfeladatok és -tevékenységek valamennyi területén képes lehet versenyelőny forrást biztosítani. Megelőző kutatások azt is kimondták, hogy a képességek fejlesztése valamint kialakítása szervezeti tanulás révén valósítható meg (Liu-Ko, 2012; Easterby-Smith - Prieto, 2008).

Amennyiben a vállalatok marketingosztályának a müködését a közösségi média előtt és után vizsgáljuk, egyértelmü, hogy ezeknek a képességeknek egy bizonyos „készletével” kellett rendelkezzenek a közösségi média éra előtt, és ennek bizonyos változására van szükség ahhoz, hogy a különböző közösségi platformokon (ld. 13. táblázat ) meg tudják valósítani stratégiájukat.

A kérdés vizsgálható vezetői és operatív szinten is, mivel felmerülhet a kérdés, hogy milyen (új/régi) vezetői készségek kellenek ahhoz, hogy a megváltozott környezetben a vállalat sikeres tudjon maradni?

A mintzbergi iskola a hagyományos vállalatszervezés elveit követi, és ahol a vállalat határai egyértelmüen meghúzhatóak, a struktúra a cég és nem a közös értékajánlat megalkotására egymással szövetkező partnerek jellemzője (Olson et al., 2005). A témában folytatott elökutatás valamint a szakirodalom egyértelmúen abba az irányba mutat, hogy itt másról, többről van szó. Az elmúlt nagyjából két 99 
évtizedben egyre több szerző írta le a vállalati müködést a biológiából kölcsönzött ökoszisztéma terminológiával (Iansiti-Levien, 2004; Adner, 2017; West-Wood 2013; stb). Így felmerül kérdésként, hogy melyiket képességet érdemes a vállalaton belül tartani és melyiket szervezzék ki, milyen döntési kritériumai lehetnek ennek?

\section{RQ4. Hogyan alakította át a marketingszervezet tudás és kompetencia igényét a közösségi média implementációja?}

A szervezeti tanulás, valamint a tanuló szervezet két fogalom, ami magyarázatot adhat ezekre. Argote (2012) ciklikus modellje nemcsak megteremti a kapcsolatot a vállalatitudásbázis és a szervezet környezete között, de a tanulási folyamatnak a környezetre történő visszahatására, annak átalakítására is egyfajta magyarázatot nyújt.

A szakirodalom alapján a közösségi média megközelíthető úgy is, mint diszruptív innováció, amely számos iparágban hozott átrendeződést (Pegoraro, 2014; Ghezzi et al., 2016; Flew, 2017; Anderson, 2016, stb). Ez a megközelítés a marketing különböző területeit érintheti: kommunikáció, értékesítés, piackutatás, stb.

Feltehető, hogy ez az átalakulás a reklámiparban is lecsapódott és hatásai a munkaerő keresletben, és így az álláshirdetésekben kimutatható. A diszruptív innováció hatása legalább két ponton kimutatható kell, hogy legyen:

- bizonyos készségek, képességek és tudás iránti kereslet növekedésében és ezzel egy időben más készségek, képességek és tudás iránti kereslet csökkenésében (megszünésében)

- iparágakon belül: egyes szektorokban/vállalatoknál az igények nagymértékü növekedésére, más versenytársaknál csökkenés/megszünés valószínüsíthető. 
Bár látható, milyen széleskörü változásokat indukált a közösségi média, megelőző kutatások mégis csupán részlegesen foglalkoztak azzal, hogy ez az átalakulás milyen szervezeti konzekvenciákkal jár (Leeflang et al., 2014, Choi-Thoeni, 2016). Feltételezésem szerint az elmúlt években a marketingosztályok felépítésében és müködésében is megfigyelhetővé vált az, hogy ökoszisztéma szerű működésben a szervezeti határok elmosódnak, a közös értékalkotás céljával külső (szervezeten kívüli) partnerek szerepe jelentősebbé vált és, hogy ezeket a változások változásokat a közösségi média indukálta vagy erösítette fel.

\subsection{Kutatási módszertan}

A kutatás - célozza akár társadalmi vagy véleménykérdések feltárását - az egyénekre vagy szervezetekre vonatkozó információk szisztematikus gyüjtése, értelmezése a téma szempontjából releváns statisztikai, elemzési módszertan segítségével. Az egyes lépései az információk szisztematikus, objektív feltárása, összegyüjtése, elemzése, közlése, valamint felhasználása (Malhotra-Simon, 2008 valamint ESOMAR, 2010 in: Gyulavári et al., 2014). A társadalomtudományok kutatás módszertani eszköztára meglehetősen széles körü, kvalitatív, kvantitatív és vegyes módszertant is széles körben alkalmaznak a kutatók. Jelen kutatás ez utóbbi kategóriába tartozik: kvalitatív és kvantitatív eszközöket egyszerre alkalmaz a téma feltáró jellege miatt.

Az egyes módszertanok alapvetően eltérő megközelítést alkalmaznak annak függvényében, hogy az adatokat kvalitatív vagy kvantitatív jelleggel gyüjtik illetve elemzik. A kvalitatív adatfelvételt és -elemzést akkor célszerü alkalmazni, amennyiben a vizsgált téma nem teszi lehetővé számszerü adatok mérését, alkalmazása révén olyan értékes információk tárhatóak fel, melyek a hagyományos statisztikai elemzéseken alapuló módszertan segítségével nehezen vagy egyáltalán nem érhetőek el. Az ilyen jellegü kutatások természete gyakran felderítő és nem magyarázó jellegü, ennek előnye lehet, hogy a kutatási területekre vonatkozóan új belátást biztosít: azaz olyan információt, melyre sem saját tudása, sem a szakirodalom feltérképezése alapján nem tudott következtetni a kutató. 
A szakirodalom alapján az alábbi különbségtétel fogalmazható meg a két megközelítés mód között:

\begin{tabular}{|c|c|c|}
\hline Szempont & Kvalitatív kutatás & Kvantitatív kutatás \\
\hline $\begin{array}{l}\text { A valóság } \\
\text { feltételezett } \\
\text { természete }\end{array}$ & $\begin{array}{l}\text { „Belsős perspektíva” - } \\
\text { émikus } \\
\text { Többes } \\
\text { szubjektív }\end{array}$ & $\begin{array}{l}\text { Objektív világnézet - étikus } \\
\text { Egyetlen valóság, objektív }\end{array}$ \\
\hline Kutató szerepe & $\begin{array}{l}\text { Személyes bevonódás, } \\
\text { elköteleződés, a kutató } \\
\text { „maga az eszköz” }\end{array}$ & $\begin{array}{l}\text { Objektivitásra, részrehajlás } \\
\text { mentességre törekvés }\end{array}$ \\
\hline Cél & $\begin{array}{l}\text { Társadalmi interakció } \\
\text { megértése és interpretálása }\end{array}$ & $\begin{array}{l}\text { Hipotézis tesztelés, az oko és } \\
\text { hatások vizsgálata, előrejelzés }\end{array}$ \\
\hline $\begin{array}{l}\text { Minta, } \\
\text { megfigyelési } \\
\text { egység }\end{array}$ & $\begin{array}{l}\text { Kisebb, nem } \\
\text { véletlenszerűen választott } \\
\text { (elméleti minta) }\end{array}$ & Nagyobb, véletlenszerü \\
\hline Változók & $\begin{array}{l}\text { Nem változók, hanem az } \\
\text { egész jelenség } \\
\text { tanulmányozása }\end{array}$ & $\begin{array}{ll}\text { Konkrét } & \text { változók } \\
\text { tanulmányozása } & \end{array}$ \\
\hline $\begin{array}{l}\text { Gyüjtött adatok } \\
\text { típusa }\end{array}$ & $\begin{array}{l}\text { Szavak, képek vagy } \\
\text { tárgyak }\end{array}$ & Számok, statisztikák \\
\hline $\begin{array}{l}\text { Adatgyüjtés } \\
\text { formája }\end{array}$ & $\begin{array}{l}\text { Kvalitatív jellegü: nyílt } \\
\text { végü kérdések, interjú, } \\
\text { megfigyelés, stb }\end{array}$ & $\begin{array}{l}\text { Pontos mérés révén gyüjtött } \\
\text { kvantitatív adtok, strukturált, } \\
\text { validált adatgyüjtési eszközök } \\
\text { révén }\end{array}$ \\
\hline
\end{tabular}




\begin{tabular}{|c|c|c|}
\hline Szempont & Kvalitatív kutatás & Kvantitatív kutatás \\
\hline Adatelemzés & $\begin{array}{l}\text { Mintázatok, } \\
\text { jellegzetességek } \\
\text { beazonosítása }\end{array}$ & Statisztikai összefüggések \\
\hline $\begin{array}{l}\text { Objektivitás és } \\
\text { szubjektivitás }\end{array}$ & Szubjektivitás elvárás & Az objektivitás elvárás \\
\hline Eredmények & $\begin{array}{l}\text { Egyedi, } \\
\text { eredmények, } \\
\text { általánosítható }\end{array}$ & $\begin{array}{l}\text { Általánosítható } \\
\text { következtetések, melyek más } \\
\text { mintára is alkalmazhatóak }\end{array}$ \\
\hline $\begin{array}{l}\text { Tudományos } \\
\text { módszer }\end{array}$ & $\begin{array}{l}\text { Feltáró (bottom-up): a } \\
\text { kutató új hipotéziseket, } \\
\text { elméleteket fogalmaz meg } \\
\text { a gyüjtött adatok alapján }\end{array}$ & $\begin{array}{l}\text { Megerösítő (top-down): a } \\
\text { kutató hipotéziseket, } \\
\text { elméleteket tesztel az adatokon }\end{array}$ \\
\hline $\begin{array}{l}\text { Az emberi } \\
\text { viselkedés } \\
\text { megközelítés } \\
\text { módja }\end{array}$ & $\begin{array}{l}\text { Dinamikus, szituációs, } \\
\text { társadalmi és személyes }\end{array}$ & Szokványos, elöre jelezhető \\
\hline $\begin{array}{l}\text { A legáltalánosabb } \\
\text { kutatási célok }\end{array}$ & $\begin{array}{l}\text { Feltárás, felfedezés, } \\
\text { elméletalkotás }\end{array}$ & Leíró, magyarázó, előrejelző \\
\hline Fókusz & $\begin{array}{l}\text { Széles körü, a jelenségek } \\
\text { mélységét és kiterjedtségét } \\
\text { vizsgálja }\end{array}$ & $\begin{array}{l}\text { Szük fókusz, konkrét } \\
\text { hipotézisek tesztelése }\end{array}$ \\
\hline $\begin{array}{l}\text { A megfigyelés } \\
\text { természete }\end{array}$ & $\begin{array}{l}\text { A természetes } \\
\text { környezetben } \\
\text { tanulmányozza } \\
\text { viselkedést }\end{array}$ & $\begin{array}{l}\text { Magatartás vizsgálata } \\
\text { kontrollált } \quad \text { körülmények } \\
\text { között, eseti hatások kizárása }\end{array}$ \\
\hline
\end{tabular}




\begin{tabular}{|l|l|lr|}
\hline Szempont & \multicolumn{2}{|l|}{ Kvalitatív kutatás } & \multicolumn{2}{l|}{ Kvantitatív kutatás } \\
\hline Végső jelentés & Narratív beszámoló & Statisztikai & jelentés \\
& $\begin{array}{l}\text { kontextuális leírással és a } \\
\text { résztvevőktől származó } \\
\text { hipotézis }\end{array}$ & vizsgálat, & statisztikai \\
& idézetekkel & szignifikancia szintek) \\
\hline
\end{tabular}

Táblázat 18: A kvalitatív és kvantitatív kutatás összehasonlítása

Forrás: Sayre, 2001, Johnson-Christensen, 2008, p.34., Lichtman, 2006, p7-8.,

Az összehasonlító táblázatból kiderül: a kvantitatív kutatás, illetve szemléletmód elsősorban olyan kutatási kérdések esetén alkalmazható megfelelő módon, ahol hipotézisek felállítására már van lehetőség, a téma jobban körül határolható, egzaktabb - esetleg a szakirodalomban már jobban feltárt. A kvalitatív megközelítés ezzel szemben induktív logikára épít, és olyan társadalomtudományi módszertanokra épít, ahol megengedett, sőt kívánatos a többes valóságlátás, a kutatás fókusza pedig az interakcióra esik. Fontos leszögezni, hogy tudományos szempontból egyik megközelítésmód sem nevezhető „felsőbb rangúnak” vagy kívánatosabbnak, inkább arról van szó, hogy az eltérő jelenségek eltérő megközelítési módot, világlátást követelnek meg. A kutatási módszertan megválasztásakor így a legfontosabb feladat, hogy a kutatási probléma ismeretében az ahhoz leginkább passzoló módszertan kerüljön kiválasztásra.

A tudományos kutatások eredményeit három fő kritérium mentén szokás értékelni, melyet a választott módszertan alapvetően meghatároz - ld. a következő táblázatban: 


\begin{tabular}{|c|c|c|c|}
\hline Szempont & $\begin{array}{l}\text { Rövid } \\
\text { magyarázat }\end{array}$ & Kvalitatív kutatás & Kvantitatív kutatás \\
\hline $\begin{array}{l}\text { Megbízha- } \\
\text { tóság }\end{array}$ & $\begin{array}{l}\text { A kutatást } \\
\text { azonos } \\
\text { körülmények } \\
\text { között } \\
\text { megismételve } \\
\text { ugyanarra az } \\
\text { eredményre } \\
\text { jutunk }\end{array}$ & $\begin{array}{l}\text { Gyenge pont } \\
\text { (megfigyelés, } \\
\text { szubjektivitás és } \\
\text { kontextus függőség } \\
\text { miatt) }\end{array}$ & Erőssége \\
\hline Érvényesség & $\begin{array}{l}\text { A kutatás } \\
\text { valóban azt méri, } \\
\text { amit szerettünk } \\
\text { volna }\end{array}$ & $\begin{array}{l}\text { Erőssége (a kutató } \\
\text { holisztikus } \\
\text { szemlélettel arra } \\
\text { törekedik, hogy minél } \\
\text { mélyebben, minél } \\
\text { pontosabban tárja fel } \\
\text { és értse meg a vizsgált } \\
\text { jelenséget) }\end{array}$ & Gyenge pont \\
\hline $\begin{array}{l}\text { Általánosít- } \\
\text { hatóság }\end{array}$ & $\begin{array}{l}\text { A kutatás } \\
\text { eredményei a } \\
\text { kutatás } \\
\text { kontextusán } \\
\text { kívül is igazak }\end{array}$ & $\begin{array}{l}\text { Nem valószínüségi, } \\
\text { hanem elméleti minta, } \\
\text { kevéssé / nem } \\
\text { általánosítható } \\
\text { eredmények }\end{array}$ & $\begin{array}{l}\text { A minta } \\
\text { reprezentativitásától } \\
\text { függ, valószínüségi } \\
\text { mintavétel esetén } \\
\text { erős }\end{array}$ \\
\hline
\end{tabular}

19. táblázat: Kvalitatív és kvantitatív kutatások összevetése megbízhatóság, érvényesség és általánosíthatóság szempontjából.

Forrás: Sztárayné (2011)

A korábban ismertetett kutatási kérdések egy nem jól definiált és nem egyértelmüen lehatárolható problémára utalnak, melyet az előzetes kutatások is megerősítettek. Ezek azt is feltárták, hogy sok az ad-hoc jellegü megoldás, a szervezeti reakciót egzakt döntéshozatali procedúrák helyett gyakran a vezető pozícióban dolgozó munkatársak személyes benyomásai, vélekedései dominálják. A bizonytalansági tényezőket sorát szaporítja a turbulens piaci környezet is. 
Mindezek abba az irányba mutatnak, hogy a helyzet alapvetően feltáró és nem megerősítő jellegű kutatást kívánnak meg. A helyzettel kapcsolatos információk egy jelentős része szűk számú, kiterjedt személyes tudással és nagy tapasztalatokkal rendelkező szakértő, menedzser fejében található meg. Ezek a tényezők a helyzet egy kvalitatív, feltáró jellegü kutatás létjogosultságát támasztja alá: a cél ugyanis nem bizonyos helyzet leírása vagy elörejelzések biztosítása, hanem a kutatási fókuszban álló jelenség pontosabb megértése, szakértőktől származó információk, illetve az ő vélekedéseik és tapasztalataik alapján.

A kutatási irányok valamint a rendelkezésre álló lehetőségek alapján vegyes módszertan alkalmazása mellett döntöttem. Ez azt jelenti, hogy kvalitatív és kvantitatív eszközöket egyszerre alkalmaztam. Ez a megközelítés a társdalomtudományokban az elmúlt mintegy két évtizedben mind gyakrabban alkalmazott megközelítéssé vált (Denscombe, 2008), egyes szerzők érvelése szerint mára a tisztán kvalitatív és tisztán kvantitatív kutatási módszertan mellett önálló kutatási paradigmaként ismerhető elé (Johnson et al., 2007). Morse-Niehaus (2009) terminológiájával összhangban a 'vegyes módszertan' kifejezést úgy használom, mint több, egymásra kölcsönösen támaszkodó, és egymástól függetlenül nem publikálható kutatási metódus (szemben például a ’többes módszertan'-nal).

Creswell-David (2018) az alábbi szempontokra hívja fel a figyelmet, amelyek alapján a vegyes módszertannal készülö kutatások eltérhetnek egymástól

- időzítés: a kutatási fázisok lehetnek egymás követőek valamint egymással párhuzamosan zajlóak

- súlyozás: az egyes kutatási fázisok fontossága, prioritása

- vegyítés típusa: összekötő (az egyik kutatási fázis adatfelvétele egy másik kutatási gázis adatelemzésén alapul), integráló (a különböző kutatási fázisokból nyert adatbázisok egyesítését jelenti) vagy beágyazó (a kutató nem köti össze és nem is integrálja a kutatási fázisokat, az egyik kutatási fázis a másikat támogatja) 
- elméletalkotás, vagyis az, hogy a kutató milyen módon alkalmaz elméleti keretet a kutatás tervezésében. Lehet explicit (az elméleti keret bemutatásra kerül) illetve implicit (nincs szó elméleti keretről)

A fenti jellemzők egyúttal a kutatás irányát is kijelölik, jelen kutatás a szerző által felállított módszertani lehetőségek közül a párhuzamos transzformatív stratégiát követi, vagyis a kutatás során egy elméleti keretre alapozva egyidejüleg kerül gyüjtésre kvalitatív és kvantitatív adat. Az elemzésben az adatbázisok egymással való összevetése, valamint közös feldolgozása is megtörténhet:
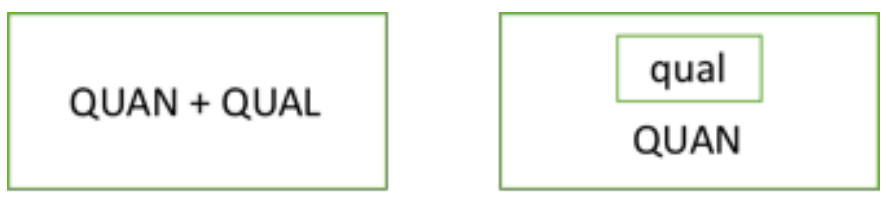

\section{Ábra 24: Párhuzamos transzformatív kutatástervezés \\ Forrás: Cresswell-David, 2018 p.210}

A kvalitatív eszközök alkalmazását indokolta a kutatásban, hogy ez módszertan lehetővé teszi azt, hogy a vizsgált problémát mélyebben, a megkérdezésbe bevont szakértőkön keresztül ismerjen meg, így a társadalmi változások mélyebb megértése és feltárása válik lehetségessé (Mertens, 2010). A kvantitatív kutatás ugyanakkor konkrét változók tanulmányozására biztosít lehetőséget, a kutatás megbízhatósága erősebb. A két módszertan kombinációja egy kutatáson belül felerősíti az egyes módszertanok erősségét, és minimalizálja azok gyengeségeit (Yin, 2017).

Utolsó szempontként a mintaválasztás lehetőségeiről is szót kell ejtenünk. Kvalitatív kutatás esetén - a módszertan logikájából eredően - egészen más típusú megközelítés módot kell követni, mint a statisztikai valószínűségre építő kvantitatív kutatások esetén. Miles-Huberman (1994) az alábbi táblázatban foglalja össze a szóba jöhető változatokat:

\begin{tabular}{|l|l|}
\hline Mintavétel & Célja \\
\hline Maximális változatosság & $\begin{array}{l}\text { Az átlagostól eltérő esetek dokumentálása révén } \\
\text { fontos közös jellemvonások feltárása }\end{array}$ \\
\hline
\end{tabular}




\begin{tabular}{|c|c|}
\hline Mintavétel & Célja \\
\hline Homogén & $\begin{array}{l}\text { Egyszerüsíti, fókuszálja, megvalósíthatóvá teszi a } \\
\text { csoportos interjúkat }\end{array}$ \\
\hline Kritikus eset & $\begin{array}{l}\text { A lehetőségekhez képest maximális } \\
\text { általánosíthatóság biztosítása }\end{array}$ \\
\hline Elméleti & $\begin{array}{l}\text { Esetek kiválogatása egy elméleti konstrukció alapján, } \\
\text { lehetővé teszi annak pontosabb kidolgozását, } \\
\text { vizsgálatát }\end{array}$ \\
\hline $\begin{array}{l}\text { Megerősítő és cáfoló } \\
\text { esetek }\end{array}$ & $\begin{array}{l}\text { Kezdeti elemzés pontosítása, kivételek vagy } \\
\text { változatosság keresése }\end{array}$ \\
\hline Hógolyó vagy lánc elvű & $\begin{array}{llll}\text { Információ-dús esetek beazonosítása } & \text { személyes } \\
\text { ajánlás alapján } & & & \end{array}$ \\
\hline $\begin{array}{lll}\text { Extrém vagy deviáns } \\
\text { esetek }\end{array}$ & $\begin{array}{l}\text { A vizsgált jelenség szokatlan megjelenéséből való } \\
\text { tanulás }\end{array}$ \\
\hline Tipikus esetek & Az „átlagos” keresése és bemutatása \\
\hline Intenzitás & $\begin{array}{l}\text { Információ-gazdag esetek, amelyek intenzíven } \\
\text { megjelenítik a vizsgált jelenség nem szélsőséges } \\
\text { példáit }\end{array}$ \\
\hline $\begin{array}{l}\text { Politikai szempontból } \\
\text { fontos esetek }\end{array}$ & $\begin{array}{l}\text { A figyelem szándékolt felkeltésére vagy a nem kívánt } \\
\text { figyelem elkerülésére }\end{array}$ \\
\hline Véletlenszerü célirányos & $\begin{array}{l}\text { Az érvényesség növelésére, ha a lehetséges } \\
\text { célirányos minta túl nagy }\end{array}$ \\
\hline Rétegzett célirányos & $\begin{array}{l}\text { Alcsoportok megjelenítése és összehasonlíthatósága } \\
\text { érdekében }\end{array}$ \\
\hline Kritérium & $\begin{array}{l}\text { Minden olyan eset, amely bizonyos előfeltételeket } \\
\text { kielégít, a minőség szavatolása szempontjából fontos }\end{array}$ \\
\hline Opportunista & Adódó lehetőségek, új irányok követése \\
\hline Kombinált vagy kevert & $\begin{array}{l}\text { Trianguláció, rugalmasság, különféle célok } \\
\text { kielégítésére }\end{array}$ \\
\hline
\end{tabular}




\begin{tabular}{|l|l|}
\hline Mintavétel & Célja \\
\hline Kényelmi & $\begin{array}{l}\text { Idő-, pénz- és/vagy eröforrás hatékonyság, ami } \\
\text { azonban az érvényesség gyengülését és } \\
\text { információvesztést eredményez }\end{array}$ \\
\hline
\end{tabular}

Táblázat 20: Kvalitatív kutatás mintaválasztási stratégiáinak tipológiája Forrás: Miles-Huberman, 1994, p. 28

\subsection{Kutatástervezés}

A disszertáció empirikus kutatása több fázisban valósult meg. Első lépésben a téma lehatárolása kijelölte azt a szakirodalmi kört, amelynek vizsgálata révén megfogalmazódott a kutatási kérdések előzetes köre. Ezt szakértői mélyinterjúk követték, melyek részben a megkérdezésbe bevont marketingszakemberek tudása részben pedig a hazai piacról szerzett, máshonnan meg nem szerezhető ismereteik révén segítette letisztázni és pontosítani a kutatás határait.

Az ezt követő, harmadik kutatási fázisban fogalmazódott meg, hogy a kutatás fő célja a közösségi média marketing által indukált szervezeti változások vizsgálata lesz. Ez a pontosítás egyúttal a szakirodalmi kutatás részbeni újragondolását és kiegészítését igényelte.

Az empirikus kutatás három részből tevődött össze, vegyesen alkalmazva kvalitatív és kvantitatív eszközöket:

\begin{tabular}{|c|c|c|}
\hline Kutatási fázis & Módszertan & Kutatás leírása \\
\hline Szakértői mélyinterjú & Kvalitatív & 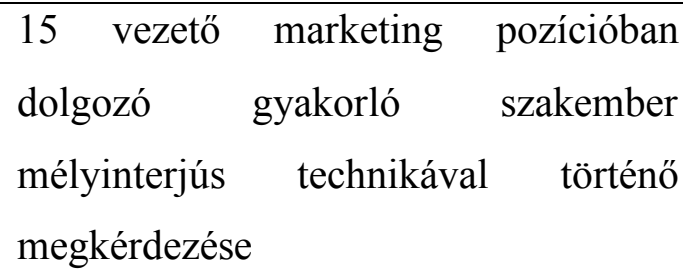 \\
\hline $\begin{array}{l}\text { Álláshirdetés adatbázis } \\
\text { elemzése }\end{array}$ & Kvantitatív & $\begin{array}{l}\text { A legnagyobb magyarországi } \\
\text { álláshirdetés adatbázis 2010-2018 } \\
\text { között „marketing” kategóriában } \\
\text { publikált álláshirdetéseinek elemzése } \\
(\mathrm{n}=2.416)\end{array}$ \\
\hline
\end{tabular}




\begin{tabular}{|l|l|l|}
\hline Kutatási fázis & Módszertan & Kutatás leírása \\
\hline $\begin{array}{l}\text { Céges riportok } \\
\text { tartalomelemzése }\end{array}$ & Kvalitatív & $\begin{array}{l}15 \text { marketing pozícióban dolgozó, esti } \\
\text { tagozatos, MA szakos egyetemista által } \\
\text { írt céges beszámoló tartalmának } \\
\text { elemzése }\end{array}$ \\
\hline
\end{tabular}

Táblázat 21: Az empirikus kutatás fázisai

Forrás: saját szerkesztés

Előzetes várakozásaim szerint az egyes kutatási módszerek az alábbi módon segíthetnek a megfogalmazott és korábbiakban ismertetett kutatási kérdések megválaszolásában

\begin{tabular}{|l|l|l|l|}
\hline Kutatási kérdés & $\begin{array}{l}\text { Szaké. } \\
\text { mélyi. }\end{array}$ & $\begin{array}{l}\text { Ál.hird. } \\
\text { elemz. }\end{array}$ & $\begin{array}{l}\text { Cég. } \\
\text { rip. }\end{array}$ \\
\hline $\begin{array}{l}\text { RQ1: Milyen adaptációs stratégiával } \\
\text { válaszolnak a marketingszervezetek arra a } \\
\text { környezeti kihívásra, amelyet közösségi média } \\
\text { megjelenése, terjedése jelent }\end{array}$ & Nél & $\begin{array}{l}\text { Kiemelt } \\
\text { cél }\end{array}$ \\
\hline $\begin{array}{l}\text { RQ2. Milyen típusú kihívásokkal kell } \\
\text { megküzdeniük a marketingosztályoknak a } \\
\text { közösségi média implementációjában a magyar } \\
\text { piacon? }\end{array}$ & Nem cél & Cél \\
\hline $\begin{array}{l}\text { RQ3. A közösségi média sikeres } \\
\text { implementációjához a vállalatoknak milyen új } \\
\text { marketing képességek megszerzésére van } \\
\text { szükségük? }\end{array}$ & Cél & Cél \\
\hline $\begin{array}{l}\text { RQ4. Hogyan alakította át a marketingszervezet } \\
\text { tudás és kompetencia igényét a közösségi } \\
\text { média implementációja? }\end{array}$ & Cél & Cél \\
\hline
\end{tabular}

Táblázat 22: A kutatási kérdések és kutatási fázisok kapcsolata

Forrás: saját szerkesztés

A fenti táblázatból kiderül az is, hogy mindegyik kutatási kérdést legkevesebb két kutatással vizsgálok, az eredmények összevetésével megvalósul az adatok 110 
triangulációja, ami erősíti a fogalmi érvényességet. A kvalitatív és kvantitatív, vagy eltérő kutatási módszerek együttes alkalmazásával (módszertani trianguláció) a kutatás pontossága is növelhető, ezáltal megbízhatóbbá teszi a folyamatot. (Yin, 2017)

\section{Előkutatás}

A kutatás első lépését két mélyinterjú jelentette, ahol a reklámiparban több éves tapasztalatokkal rendelkező szakértők segítségével a közösségi média vállalati alkalmazása és annak lehetőségei, illetve következményei kerültek feltárásra. A megkérdezések, valamint az eredmények kiértékelése a disszertáció tézistervezetének írását megelőzően történt, 2016. novemberében, félig-strukturált vezérfonal segítségével, ezzel biztosítva lehetőséget a megkérdezetteknek arra, hogy saját szakmai tapasztalataik alapján új, releváns szempontokkal gazdagítsák a kutatást.

Az előkutatás során megkérdezett szakértők (anonimizált ${ }^{12}$ ) adatai az alábbiak voltak:

- H. Zs. Online marketing szakértő, médiatervező és vásárló (4,5 év ügynökségi tapasztalat, 1,5 év ügyféloldali vezetői tapasztalat)

- Ny. N. Médiatervező és -vásárló, marketing menedzser (7 év ügynökségi tapasztalat, 2,5 év ügyféloldali vezetöi tapasztalat)

Az előkutatás során az alábbi tényezők merültek fel:

\footnotetext{
${ }^{12}$ A beszélgetések során a megkérdezettek kritikus hangot ütöttek meg, néha saját munkaadójukkal szemben is, ezért döntöttem a nevek anonimizálása mellett.
} 


\begin{tabular}{|c|c|c|c|c|}
\hline Fogyasztó & Vállalat & $\begin{array}{l}\text { Fogyasztó- } \\
\text { vállalat } \\
\text { kapcsolat }\end{array}$ & $\begin{array}{l}\text { Vállalati } \\
\text { ökoszisztéma }\end{array}$ & Környezet \\
\hline \multirow[t]{4}{*}{$\begin{array}{l}\text { Változó } \\
\text { médiahasználati } \\
\text { szokások }\end{array}$} & $\begin{array}{l}\text { Reklámköltés: } \\
\text { erős kontroll } \\
\text { (olcsóbb vs. } \\
\text { drágább } \\
\text { csatornák) }\end{array}$ & $\begin{array}{l}\text { Kommunikáció } \\
\text { változása }\end{array}$ & $\begin{array}{l}\text { Ügynökségek } \\
\text { szerepének } \\
\text { változása }\end{array}$ & $\begin{array}{l}\text { A magyar piac } \\
\text { szerkezeti } \\
\text { sajátosságai }\end{array}$ \\
\hline & Reklámcélok & & $\begin{array}{l}\text { Ügynökség: } \\
\text { szakmai } \\
\text { tartalom } \\
\text { mellett egyéb } \\
\text { szempontok } \\
\text { (pl. jutalék) }\end{array}$ & \begin{tabular}{|l} 
Hazai \\
központok a \\
külföldi HQ \\
irányítása alatt
\end{tabular} \\
\hline & $\begin{array}{l}\text { Iparági } \\
\text { sajátosságok }\end{array}$ & & $\begin{array}{l}\text { Ujj } \\
\text { szakértelem: }\end{array}$ & $\begin{array}{l}\text { Marketing } \\
\text { fejlesztések } \\
\text { terén } \\
\text { elmaradott } \\
\text { piac }\end{array}$ \\
\hline & $\begin{array}{l}\text { Mérés: korábbi } \\
\text { mérőszámok } \\
\text { és az online } \\
\text { mérés } \\
\text { kompatibilitási } \\
\text { problémái }\end{array}$ & & & $\begin{array}{l}\text { Konzervatív } \\
\text { attitüd } \\
\text { reklámozásban } \\
\text { (hagyományos } \\
\text { csatornák } \\
\text { dominálják, pl: } \\
\text { TV) }\end{array}$ \\
\hline
\end{tabular}

Táblázat 23: Az előkutatás során felmerült tényezők

Forrás: saját szerkesztés

\section{Kutatás első fázisa: szakértői mélyinterjúk}

A helyzet pontosabb megértését a szakirodalomból leszürt tanulságok alapján szakértői mélyinterjúk segítették. A kutatás első fázisában 10 mélyinterjú készült 112 
gyakorló marketing menedzserek bevonásával. A megkérdezésben olyan szakértők vettek részt, akik mindannyian aktívan részt vesznek digitális marketinggel kapcsolatos feladatokban és/vagy projektekben. A megkérdezettek bevonásában további cél volt az iparági sokszínüség, valamint az, hogy ügynökségi és vállalati szakemberek egyaránt szerepeljenek a megkérdezésben, ami egy szélesebb körü rálátást biztos az iparági folyamatokra. Ez a szervezeti külső/belső határok elmosódásával kapcsolatos kutatási kérdés megválaszolásában nyújthat segítséget.

\subsection{Adatgyűjtés}

Az adatgyüjtés során 10 mélyinterjú készült, a megkérdezésbe bevont marketing szakértők szakmai tapasztalatát és iparági hátterét a ... táblázat mutatja be. A mélyinterjúk félig strukturált formában zajlottak, a megkérdezés helyszíne a válaszadók munkahelye volt. (Az interjúk vezérfonalát $1 d$. ... melléklet). Az interjúk időtartama 50-110 perc közötti volt, ennyi idő elegendő volt arra, hogy a megkérdezettek kifejtsék álláspontjukat és megosszák tapasztalataikat a kérdezőbiztossal. A megkérdezésbe bevont szakértők beleegyezésével 9 interjúról hangfelvétel készült, melyek a későbbi elemzést segítették. A szakmai mélyinterjúk 2017. augusztus-november között készültek.

Tekintettel arra, hogy az interjúalanyok esetenként olyan információkat is megosztottak, melyek az egyes cégek életének mélyebb müködésébe is betekintést engednek, az általuk közölt információ anonimizált formában került felhasználásra. Az elmondott és kutatásban idézett mondatok mellett az interjúalany kódja utal a megkérdezettre.

Az interjúkban az alábbi marketingvezetők voltak a válaszadók:

\begin{tabular}{|c|c|c|}
\hline Kód & Jelenlegi beosztás & Korábbi (releváns) szakmai tapasztalat \\
\hline A & $\begin{array}{l}\text { Márka és kommunikációs } \\
\text { igazgató (2 év) - pénzügyi } \\
\text { szolgáltatás }\end{array}$ & $\begin{array}{l}\text { - Regionális termékmenedzser (1,5 év) - High- } \\
\text { tech } \\
\text { - Csatorna marketing menedzser (1 év) - FMCG } \\
\text { - Kategória menedzser (4 év) - High-tech }\end{array}$ \\
\hline
\end{tabular}




\begin{tabular}{|c|c|c|}
\hline Kód & Jelenlegi beosztás & Korábbi (releváns) szakmai tapasztalat \\
\hline B & $\begin{array}{lll}\text { Digitális } \quad \text { marketing } & \text { és } \\
\text { kommunikáció } & \text { specialista } & (1 \\
\text { év) - B2B gyártó vállalat } & \end{array}$ & - Területi képviselő (1,5 év) - B2B gyártó vállalat \\
\hline $\mathrm{C}$ & $\begin{array}{l}\text { Marketing kommunikáció } \\
\text { vezető (4 év) - B2C szolgáltató }\end{array}$ & $\begin{array}{l}\text { - Regionális digitális vezető (2 év) - FMCG } \\
\text { - Integrált kommunikáció regionális vezetője (2 } \\
\text { év) - FMCG } \\
\text { - Márkamenedzser (3 év) - FMCG }\end{array}$ \\
\hline $\mathrm{D}$ & $\begin{array}{l}\text { Ügyvezető igazgató, Média és } \\
\text { Digitális } \quad \text { Kommunikációs } \\
\text { ügynökség (1 év) }\end{array}$ & $\begin{array}{l}\text { - Ügyvezető igazgató (3 év) - online B2B és B2C } \\
\text { szolgáltatás } \\
\text { - Elnök ( } 7 \text { év) - tanácsadó szervezet } \\
\text { - Ügyvezető igazgató ( } 3 \text { év) - online marketing } \\
\text { ügynökség } \\
\text { - Területvezető (6 év) - online marketing } \\
\text { ügynökség }\end{array}$ \\
\hline $\mathrm{E}$ & $\begin{array}{l}\text { Marketing menedzser (3 év) - } \\
\text { FMCG }\end{array}$ & - Márkacsoport menedzser (4 év) - FMCG \\
\hline $\mathrm{F}$ & $\begin{array}{l}\text { Marketing és kommunikációs } \\
\text { vezető, Digitális média vezető } \\
\text { (2 év) - FMCG }\end{array}$ & 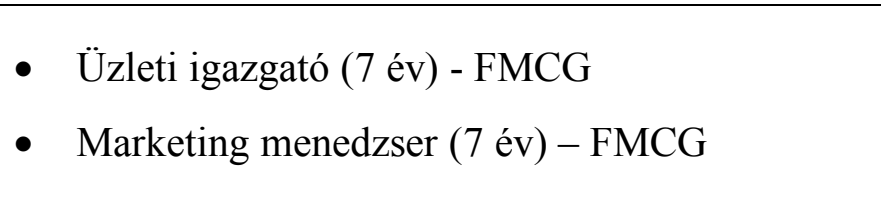 \\
\hline G & Márkamenedzser - FMCG & - Márkamenedzser (5 év) - FMCG \\
\hline $\mathrm{H}$ & $\begin{array}{l}\text { Márka és kommunikációs } \\
\text { vezető (3 év) - B2C szolgáltató }\end{array}$ & $\begin{array}{l}\text { - Helyettes ügyvezetö (3 év) - kreatív ügynökség } \\
\text { - Partner (1 év) - márkastratégiai tanácsadás } \\
\text { - Ügyvezető (2 év) - kommunikációs tanácsadás }\end{array}$ \\
\hline I & $\begin{array}{l}\text { Társtulajdonos }\left(\begin{array}{lll}4 & \text { év }\end{array}\right) \quad- \\
\text { Építőipar }\end{array}$ & - Projekt értékesítési vezető (10 év) - építőipar \\
\hline $\mathrm{J}$ & $\begin{array}{l}\text { Kommunikációs munkatárs (3 } \\
\text { év)-kommunikációs tanácsadó }\end{array}$ & - Ügyvezető igazgató (10 év) - könyv kiadó \\
\hline
\end{tabular}

Táblázat 24: Mélyinterjú alanyok bemutatása

Forrás: saját szerkesztés 
Az interjúk elkészítésére a kutatás első fázisában került sor. A kutatás ezen pontján a kutatási fókusz még nem került egyértelmü lehatárolásra, az interjúkban a szervezeti kérdések mellett számos egyéb olyan kérdés is terítékre került, melyek a vállalat és közösségi média viszonyát boncolgatták. Az ezekre adott válaszok egy külön tanulmányban kerülnek majd feldolgozásra, értékelésre.

Az interjúk elemzésében a fő cél az volt, hogy belátást biztosítson arra, hogy milyen adaptációs stratégiával válaszolnak a marketingszervezetek arra a környezeti kihívásra, amelyet közösségi média megjelenése, terjedése jelent.

\subsection{Elemzés}

\section{Helyzetértékelés}

A megkérdezésbe bevont marketingvezetők mindegyike a közösségi média vállalati célú használatának létjogosultsága mellett érvelt, az alkalmazás szintjében azonban voltak különbségek:

- „higiéniás”-tényező: legalacsonyabb szintü használatot jelenti, csupán „jelzés a vevők számára, hogy a cég létezik, él” (A). „Azért csináljuk, mert jó, hogy ott vagyunk és nem igényel nagy energia befektetést" (B);

- meghatározott cél mentén történő használat: ami jelenthet ügyfélszolgálati csatornát, értékesítés támogatást, márkaépítést, a márkarajongók közösségbe való formálását;

- stratégiai szintü használat csak opcióként merült fel, ilyen szintü elköteleződést a közösségi platformok irányába egyik vizsgált vállalat sem mutatott: „Nem biztos, hogy kivánatos lenne a marketingstratégia részévé tenni a közösségi médiát. Ez véleményem szerint szektortól is függ, egy klasszikus FMCG cég helyzete nehéz, itt akár termék szinten is vizsgálandó, hogy van-e értelme" (G). Több vállalat is jelezte, hogy a közösségi média ilyen szintü alkalmazását a jövőben elképzelhetőnek tartja.

A vezetők helyzetértékelésében közös momentum volt az, hogy csak kisebb részben a pénzbeli (költség) elönyökkel magyarázták azt, hogy miért csoportosítják 
át évről-évre növekvő arányban a marketingköltéseket a közösségi médiára. A legtöbb válaszban a fogyasztói szempontok is megjelentek: eWOM kiaknázása, belátás a fogyasztók életébe, közvetlen becsatornázódás a fogyasztók beszélgetésébe, „hétköznapjaiba”. „Az egyik leghatékonyabb módja emocionális kötődés erösitésének így márkaimázs erősitésének. Nem elhanyagolható szempont, hogy azonnali visszajelzés érkezik a fogyasztóktól, amit nagyon pontosan ki tudunk olvasni a számokból: látjuk, hogyan reagálnak. A hatékony használat kulcsa az, hogy az ó életükbe releváns módon tudjunk , belefolyni” - a hétköznapi életük része kell legyen a márka. Ezt leginkább úgy lehet elrontani, ha a márka üzeneteit ismételgetjük. Nem ezt kell csinálni, hanem azt, ami az embereket érdekeli”(E).

Többen a már meglevő („,hagyományos”) csatornákkal való összevetésben látták a közösségi médiát, az interjúk során említett médiumokat valamint ennek eredményeit az alábbi táblázat foglalja össze:

\begin{tabular}{|l|l|}
\hline Médium & Marketing vezetők által relevánsnak tartott jellemző \\
\hline Rádió & $\begin{array}{l}\text { Hatalmi bizonytalanság jellemzi a rádiós piacot (F) } \\
\text { Statikus, egyirányú (D) } \\
\text { Márkanév kiterjesztés az online médiumra (pl. hírportál } \\
\text { formájába): ritkán sikeres (J) }\end{array}$ \\
\hline Újság & $\begin{array}{l}\text { Elveszítette tömegmédium jellegét, „niché” piacok } \\
\text { kiszolgálására alkalmas (pl. női lapok, tinimagazin, stb) (F) } \\
\text { Statikus, egyirányú (D) } \\
\text { Márkanév kiterjesztés az online médiumra (pl. hírportál } \\
\text { formájába): ritkán sikeres (J) }\end{array}$ \\
\hline Televízió & $\begin{array}{l}\text { Ma is hatalmas az elérése, de a társadalom jövedelmi } \\
\text { szempontból lejjebb eső részei töltenek elötte hosszabb időt } \\
-\quad \text { nincs munkájuk, nem befolyásolók, marketing } \\
\text { szempontból kevésbé érdekes (C) } \\
\text { „Még” tömegmédia (F), de már most is sokszor jobban } \\
\text { megéri a „nichém müsorok/adók kínálatában megjelenni (C) } \\
\text { Statikus, egyirányú (D) }\end{array}$ \\
\hline
\end{tabular}




\begin{tabular}{|l|l|}
\hline Médium & Marketing vezetők által relevánsnak tartott jellemző \\
\hline Online sajtó & $\begin{array}{l}\text { Skizofrén helyzetbe került: a közösségi média „elszipkázza” } \\
\text { a reklámbevételeket, de támaszkodik is rá a látogató } \\
\text { szerzésben (D) }\end{array}$ \\
\hline Közösségi média & $\begin{array}{l}\text { Fogyasztói bevonódás csúcsa (D) } \\
\text { „Már” tömegmédia (F) } \\
\text { Megjelentek azok a reklámok, amelyek teljesen úgy } \\
\text { „viselkednek”, mintha tévéreklámok lennének (F) } \\
\text { Pontos mérés (C, E, I) } \\
\text { Az emberek a csatornán keresztül a reklámhoz való } \\
\text { viszonyukat is jelezni tudják (D) }\end{array}$ \\
\hline
\end{tabular}

Táblázat 25: Az egyes médiumok jellemzése

Forrás: saját szerkesztés

A táblázatból jól látszik, hogy a megkérdezettek körében az alapvető attitűd pozitív volt a közösségi média marketing célú használat iránt, míg a hagyományos médiumok esetében inkább a használat csökkenésére, átalakulására kell számítani (amit pl. a Reklámszövetség évről-évre közzétett reklámtortája is visszaigazol).

Többen beszéltek a csatorna egyedi jellemzőiről az interjú elején, kiemelve a pontosabb célzási és jobb mérési lehetőségeket, de talán az iparági vezetők félelmeit is mutatja az, hogy külön rákérdezés nélkül, többen is a negatív visszahanggal kapcsolatos aggodalmaikat is megfogalmazták. „Tapasztaltuk, látjuk: a negativ hír villámgyorsan el tud terjedni, és ehhez elég egy panaszos ügyféltől érkezö fenyegetödzés. Sok helyütt látom, hogy a marketingesek félnek attól, hogy a cég negatív spirálba kerülhet” (A). „A fogyasztó a márka képviselőjévé válhat. Ennek van kétségkívül pozitív oldala is - de egy erös negatív visszacsatolás akár teljesen le tudja nullázni a médiaköltés értelmét, és komoly károkat okozhat a márka számára” (D).

\section{Marketing feladatok és hatáskörök}

Valamennyi megkérdezett arról beszélt, hogy a közösségi média marketingfeladatok közé történő integrálásával a marketingszervezetek által ellátott 
feladatok mennyisége erőteljesen megnövekedett. "Mindent átalakitott. Régebben sokkal rövidebb volt a folyamat: termékhez illeszkedö célcsoport, kommunikációs ötlet alapján megalkotott kreativ anyagokat -ügynökségi segitséggel vagy semgyakorlatilag 1-2 hét alatt elkészitettük, és ezzel a munkánk nagyjából véget is ért. Most a folyamat eleje változatlan, de a közzétételt követöen sokkal több munka hárul ránk, mint korábban" (C).

Olyan új feladatokról számoltak be, mint a vevői beszélgetések monitorozása (social listening - a teljes online térben), influencerekkel való intenzív együttmüködés, versenytárs tevékenységek nyomon követése, adatelemzés (big data). De a már meglevő feladatok mennyisége is nő: ,hetente 3 poszttal dolgozunk a Facebook-on. Egy-egy tartalmat legyártani semmivel nem kevesebb munka, mint korábban egy Citylight vagy egy óriásposzter megalkotása" (E). És miközben a befektetett munka azonos vagy még több is, mint korábban, az elékszült alkotások „élettartama” órákban, legfeljebb napokban mérhető (E, C, H).

A folyamatos monitorozás (hozzászólások, reakciók, stb) egyúttal folyamatos készenlétet is igényel a cégektől, hiszen a valós idejü kampányadatok rendelkezésre állása miatt nagy a nyomás a marketingosztályon, hogy a lehető leggyorsabban beavatkozzon, ha a folyamatok nem kedvező irányba mennek. „A tévéreklámoknál ha hibázott valaki és rosszul sült el a dolog, 1-2 nap alatt le lehetett állítani a kampányt, és még mindig volt idö gondolkodni azon, hogy hogyan tovább. Most egy elpuskázott kampány, ha végig söpör az interneten, neadjisten felháborodást generál, akkor 1-2 óránk van kitalálni, hogyan reagáljunk, milyen közleményt adjunk kis, stb." (I).

A csatornák növekvő mennyisége (pl. különböző közösségi oldalak) egyúttal azt is jelentik, hogy ugyanazt a tartalmat több különböző csomagolásban is „le kell gyártani”. „Korábban egy elkészült tévéanyaggal véget ért a feladat, esetleg megtámogattuk óriásplakáttal vagy magazinhirdetéssel. Most egy-egy videó anyagot 5-6 különbözö formában kell elkészíteni. A jövő márkamenedzsere kiváló tartalomszerkesztö, aki hatékonyan tud mozgatni újságírókból, grafikai szerkesztökböl, videóvágókból, operatörökböl, stb álló csapatokat. Egy-egy 
tartalmat nagyon sokféleképpen kell elöállítani” (A). A közösségi média jellege miatt nem csak csatornánként, de akár csatornán belül célcsoportonként is eltérő tartalmak gyártása lehet indokolt, ami tovább növeli egy-egy tartalom variációinak a számát:

\begin{tabular}{|l|l|l|l|l|}
\hline & Célcsoport-1 & Célcsoport-2 & $\ldots$ & Célcsoport-n \\
\hline KM applikáció 1 & & & & \\
\hline KM applikáció 2 & & & & \\
\hline$\ldots$ & & & & \\
\hline KM applikáció n & & & & \\
\hline
\end{tabular}

Mivel a feladatok átalakulnak, így más fajta munkavállalói kompetenciákra van szükség. Az alábbi táblázat az interjúk során a munkavállalókkal szemben említett követelményeket foglalja össze:

\begin{tabular}{|c|c|c|}
\hline $\begin{array}{l}\text { Érzelmi, attitüdbeli } \\
\text { hozzáállás }\end{array}$ & $\begin{array}{l}\text { Marketing szakmai } \\
\text { ismeretek, készségek }\end{array}$ & $\begin{array}{l}\text { Egyéb szakmai } \\
\text { ismeretek, készségek }\end{array}$ \\
\hline $\begin{array}{l}\text { Nyitottság, kíváncsi } \\
\text { hozzáállás, jó } \\
\text { kapcsolatteremtő } \\
\text { készség, ,emberismeret”, }\end{array}$ & $\begin{array}{l}\text { Kreatív kompetenciák: } \\
\text { grafikai készség, } \\
\text { videószerkesztés, } \\
\text { szövegírás }\end{array}$ & $\begin{array}{l}\text { Jó kommunikációs } \\
\text { készség }\end{array}$ \\
\hline $\begin{array}{l}\text { Részletekre } \\
\text { odafigyelés }\end{array}$ & $\begin{array}{l}\text { Tartalom kontroll és } \\
\text { tartalom } \quad \text { szerkesztés } \\
\text { (felügyelet) }\end{array}$ & $\begin{array}{l}\text { Kvantitatív, } \\
\text { matematikai-statisztikai } \\
\text { ismeretek } \\
\text { (,adatvezérelt” } \\
\text { müködés) }\end{array}$ \\
\hline
\end{tabular}

Táblázat 26: Munkavállalókkal szemben támasztott követelmények

Forrás: saját szerkesztés 
„Olyan emberekre van szükség a marketing osztályon, akiket a folyamatos kíváncsiság hajt, akik úgy gondolkodnak, hogy „,rengeteg dolgot nem tudok, de szeretném megismerni”. Kell, hogy érdekeljék öt/öket az emberi kapcsolatok, a marketingfeladatok egy jelentös része a közösségi médiában kommunikációt jelent vagy az emberi reakciók vizsgálatát. Aki nehezen teremt kapcsolatot, abból nem lesz jó munkavállaló” $(\mathrm{H})$.

A szükséges képességek listája a megkérdezettek szerint függ az iparágtól, a cég helyzetétől, a közösségi média alkalmazásának típusától, szintjétől és céljaitól, valamint a cég számára elkérhető külső forrásoktól (pl. ügynökségi kapcsolat). „Nagyon különbözö helyzetek képzehetőek el. Ha a cég például házon belül akar mindent legyártani, akkor a vevői jelzések észlelésétől a tartalmak gyártásán keresztül az ellenörzés és visszajelzések gyüjtéséig mindenre kell embert alkalmazzon. Más esetben elég lehet az, ha csupán a ,, seeding” terv megvalósítását végzi a cég, minden mást ügynökségi partnereken keresztül intéz" (C).

\section{Szervezeti átalakulás}

A szervezeti átalakulásban a megkérdezettek leginkább a „házon belül tartani vagy kiszervezni” kérdést látták bele. Ez egy még jelenleg is kialakulóban levő terület, ahol a gyakorló szakemberek között érezhető volt a vélemények sokfélesége, ami a kiforrott megoldások hiányára utal, és volt, aki ezt meg is fogalmazta: „Nagyon nincs még arra megoldás, hogy miként kell a közösségi médiát kezelni. Nálunk kettös célt szolgál: tartalmakat osztunk meg, valamint ügyfél szolgálati csatornaként is funkcionál. Ezek nagyon eltérö természetü felhasználási módok, melyeket a cégnek úgy kell külön kezelnie, hogy a vevők ezt a megkülönböztetést nem teszik meg" (A).

Az alábbi ábra a megkérdezett marketingvezetők leírását összegezve mutatja annak egy lehetséges mintáját, hogy a különálló közösségi média osztállyal rendelkező vállalatoknál hogyan zajlik a közösségi média feladatok ellátásához szükséges információ megszerzése és a folyamatok irányítása. 


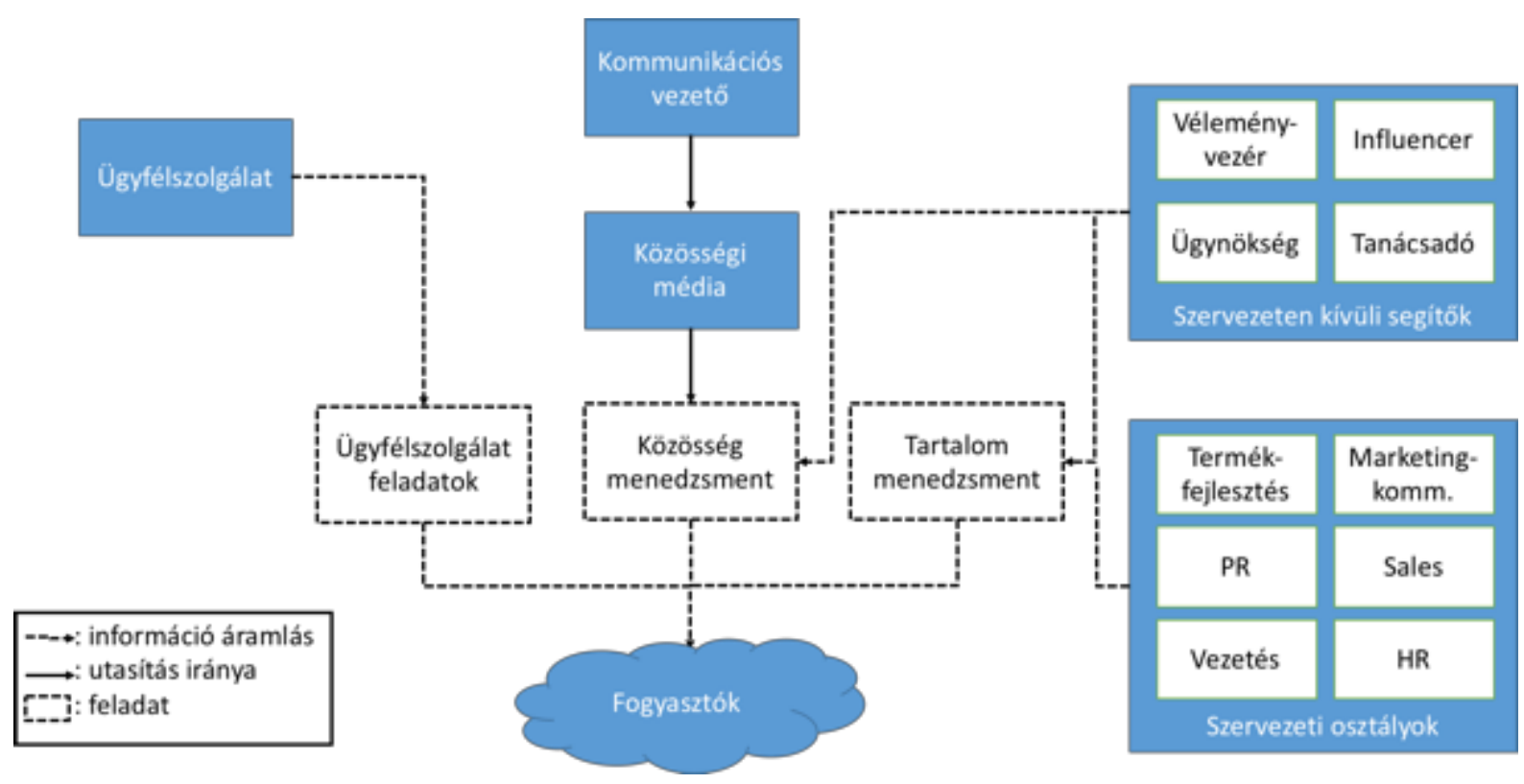

Táblázat 27: Közösségi média osztály egy lehetséges szervezeti struktúrája Forrás: saját szerkesztés

A szervezeti struktúra ki- és átalakítása mellett többször szóba került a szervezeti kultúra kérdése is, amelyet a marketingvezetők közül néhányan kulcs fontosságúnak láttak a közösségi médiában elért sikerhez: „Sokkal jobb kampányokat tudunk készíteni, ha eleve olyan hozzáállással közelítjük meg ezt a médiumot, ami közösségi médiát is jellemezi” (A).

\section{Szervezeti tanulás - tanuló szervezet}

Formális szervezeti tanulás három szintjét lehetett beazonosítani a megkérdezett vállalatok körében, azoknál a cégeknél, akik a tudás szervezeten belüli kiépítése és nem annak megvásárlása (pl. ügynökség, tanácsadó) döntöttek: egyéni szinten, csoport-, illetve szervezeti szintü tanuló folyamatokról érkeztek beszámolók. Arra a megkérdezett vállalatok körében nem volt példa, hogy a közösségi média „tanulása” ennél is magasabb, szervezetközi szinten valósult volna meg (pl. az értéklánc mentén, vagy külső formális oktatás keretében, stb).

- Egyéni szint: a mintában egy vállalatnál (B) volt megfigyelhető. Itt egyetlen munkavállaló, személyes lelkesedésből foglalkozott a közösségi médiával, az összegyüjtött tapasztalatokat másokkal semmilyen formában nem 
osztotta meg, a cég részéröl minimális támogatásban részesült (közösségi médiára a munkaideje 10 százalékát fordíthatta). A vállalat napi működésében a közösségi média egy „érdekesség”, de semmilyen szempontból nem meghatározó terület. Formalizált közösségi média stratégiával nem rendelkeztek.

- Csoport szint: közösségi médiával egy jól körülhatárolható szervezeti egység foglalkozott, a tapasztalatok megosztására első sorban informális beszélgetéseken, valamint kisebb részben formalizált formában (pl. best practise gyüjtemény, közösségi média alkalmazásokból kinyerhető történeti visszatekintő adatok, stb) került sor (I).

- Szervezeti szint: közösségi média alkalmazásával, valamint a generált tudás megosztásával nem csak egy csapat, hanem a szervezet több egysége is foglalkozott. A tudás megosztását, szervezeti disszeminációját informális beszélgetések, formalizált tudás gyüjtés és tudástár kialakítása, valamint belső oktatások is szolgálták $(\mathrm{C}, \mathrm{E}, \mathrm{F}, \mathrm{H})$.

Argote (2012) modelljét alkalmazva az elvégzett szakértői mélyinterjúkon megszerzett információkra úgy tünik: a közösségi média vállalati alkalmazásának szervezeti tanulása egyelőre még féloldalas:
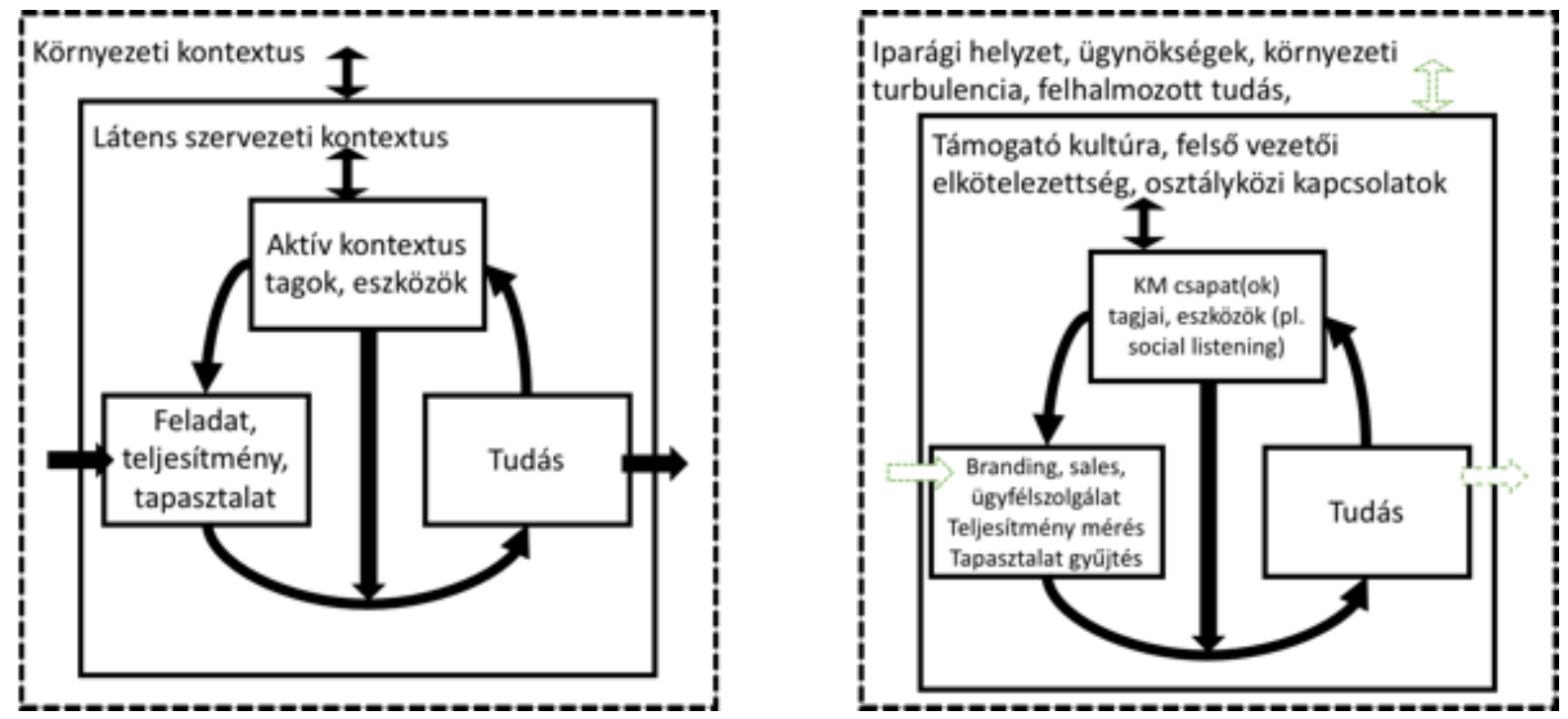

Táblázat 28: Szervezeti tanulás és a közösségi média

Forrás: saját szerkesztés 
A legnagyobb rés jelen kutatás szerint a környezet és vállalat közötti folyamatokban tapintható ki. A megkérdezettek beszámolói alapján egy olyan kép rajzolódott ki, ahol ez a fajta oda- és visszacsatolást jelentő folyamat leginkább munkavállalók fluktuációján (el- és átcsábításával) keresztül valósul meg, kisebb részben közös projektek, valamint ügynökségek igénybevételével. Több megkérdezett volt, aki akár részterületek (pl. ügyfélszolgálat) / akár a teljes közösségi média marketing terén nem látta indokoltnak ügynökségek alkalmazását.

\section{Várakozások}

Bár a kutatásnak nem volt központi fókuszában az előrejelzések begyüjtése, szinte valamennyi megkérdezett fogalmazott meg valamilyen várakozást a jövővel kapcsolatban. Míg az elmondottak alapján úgy tünik, hogy a közösségi média jelenét sok szempontból átláthatatlan állapotok, a vállalati döntéseket bizonytalanság és információ hiány jellemzi, a terület jövőjével kapcsolatban egyöntetüen optimista jóslatok hangzottak el a vezetők szájából: „Megkérdőjelezhetetlen: ez a jövő” (I). Nézetkülönbözőségeket csupán az időhorizont, valamint az elhangzó kijelentések „merészsége” jelentett.

„A közösségi média ma sokoldalú, a jövőben mindenre alkalmas lesz: ismertség növelésétől a promócióig, a forgalom irányításától az értékesítésig” (G). „Olyan irányba haladunk, hogy idővel elkerülhetetlenül a közösségi média lesz a legfontosabb a marketing számára" (A). A korábbiakban bemutatott (és még a későbbiek során tárgyalt) kutatási eredmények fényében ez jelentős változásokat vetít előre a marketingszervezet számára feladatok, struktúra és más tényezők tekintetében is.

\subsection{Következtetések}

A kutatás első fázisának célja részben a kutatási fókusz végső meghatározása volt, emellett a szakértői interjúk révén szerzett információk segítettek megismerni a közösségi média alkalmazásának jelenlegi helyzetet (helyzetfelmérés), megérteni a 123 
cégek stratégiai válaszát a közösségi médiával jellemezhető, megváltozott környezetben, és végül a jövőre vonatkozó várakozásokba is betekintést engedett.

A mélyinterjúk során feltárt fontosabb szempontokat valamint az azokból levont következtetéseket a 29. táblázat tartalmazza:

\begin{tabular}{|c|c|}
\hline Szempont & Következtetések, fontosabb kutatási megállapítások \\
\hline Helyzetértékelés & $\begin{array}{l}\text { A cégek a közösségi médiát a cégek egy része higiéniás } \\
\text { tényezőnek tekinti, máshol bizonyos feladatok ellátására } \\
\text { alkalmas eszköz } \\
\text { Az egyéb (hagyományos) médiumok megítélése } \\
\text { összességében kedvezőtlen, a közösségi médiával } \\
\text { kapcsolatos várakozások erősen pozitívak }\end{array}$ \\
\hline $\begin{array}{lll}\text { Marketing } & \text { feladatok } & \text { és } \\
\text { hatáskörök } & & \\
\end{array}$ & $\begin{array}{l}\text { A marketing szervezetek feladata legkevesebb három ponton } \\
\text { jelentősen változott: (1) növekszik az elkészített } \\
\text { reklámanyagok mennyisége; (2) az elindított kampányok } \\
\text { nyomon követése komoly energia befektetést követel; (3) a } \\
\text { csatornák számának növekvésével egy-egy kampány kreatív } \\
\text { anyagát mind több variációban kell elkészíteni. } \\
\text { Az átalakuló feladatok, növekvő munkamennyiség miatt a } \\
\text { marketingszervezetek mérete nő, új készségek és tudás } \\
\text { megszerzése vált szükségessé }\end{array}$ \\
\hline Szervezeti átalakulás & $\begin{array}{l}\text { A szervezetek számára nem egyértelmü, hogy milyen } \\
\text { formában alakítsák át saját müködésüket illetve szervezeti } \\
\text { struktúrájukat. Komoly kihívást jelent a feladatok } \\
\text { szervezeten belüli szétosztása illetve a külső partnerek } \\
\text { bevonása közötti döntés }\end{array}$ \\
\hline $\begin{array}{l}\text { Szervezeti tanulás, tanuló } \\
\text { szervezet }\end{array}$ & $\begin{array}{l}\text { A vállalatokon belüli tudás felhalmozás már elindult, de a } \\
\text { vállalatok közötti tudás áramlás csatornái még nem épültek ki } \\
\text { teljes mértékben }\end{array}$ \\
\hline
\end{tabular}




\begin{tabular}{|l|l|}
\hline Szempont & Következtetések, fontosabb kutatási megállapítások \\
\hline Várakozások & $\begin{array}{l}\text { A megkérdezett vezetök a jövő médiumaként tekintettek a } \\
\text { közösségi médiára. A platformok marketing szempontból } \\
\text { megkérdőjelezhetetlen előnyei (pontosabb célzás, mérés, stb) } \\
\text { valamint a közösségi média jelenlegi költségelönye az itt } \\
\text { folyó reklámtevékenység drágulását vetíti előre. }\end{array}$ \\
\hline
\end{tabular}

Táblázat 29: Mélyinterjúk során feltárt fontosabb szempontok

Forrás: saját szerkesztés

\section{Kutatás második fázisa: projekt munka elemzése}

A kutatásban a Budapesti Corvinus Egyetem Master szakos, esti tagozaton tanuló hallgatói vettek részt. Feladatuk keretében, amely az általuk felvett Marketingmenedzsment tárgy féléves értékelésének a része is volt, egy általuk ismert cég vagy annál a vállalatnál kellett kutatást végrehajtaniuk, ahol dolgoznak. A kutatáshoz részletes vezérfonalat és szempontrendszert kaptak (ld. ... melléklet), amely alapján azt kellett megvizsgálniuk, hogy a közösségi média milyen módon alakította át az adott szervezet marketing osztályát és marketinggel kapcsolatos feladatait.

A hallgatóknak a feladat elvégzéséhez több akadémiai szakcikk is rendelkezésére állt, a téma mélyebb megismerését segítendő. A diákok elsődleges feladata az volt, hogy adatokat, információkat gyüjtsenek az általuk ismert cégekről. Az összegyüjtött adathalmaz elemzését, értelmezését jelen dolgozat keretében végeztem el.

\subsection{Adatgyűjtés}

Az adatok felvételére, valamint a kutatási jelentések elkészítésére a 2017-18-as év tavaszi szemeszterében került sor (2018. február-május). A kurzusdolgozat benyújtásának határidejeként 2018. május 11-e volt megjelölve. Összesen 25 hallgató nyújtotta be időre a dolgozatát. Az elemzésből 2 dolgozatot a hallgató adatvédelmi kérésére kellett kizárni, további 8 munkát az összegyűjtött adatok 
alacsony színvonala miatt kellett kihagyni. Így összesen 15 dolgozat került elemzésre, melyek adatait az alábbi táblázat tartalmazza:

\begin{tabular}{|l|l|l|l|l|}
\hline Kód & Iparág & Háttér & $\begin{array}{l}\text { Saját } \\
\text { tapasztalat }\end{array}$ & Saját kutatás \\
\hline A & Telekommunikáció & Multinacionális & Igen & 3 mélyinterjú \\
\hline B & Tanácsadás & Multinacionális & Igen & Nincs \\
\hline C & Pénzügy & $\begin{array}{l}\text { Hazai } \\
\text { nagyvállalat }\end{array}$ & Igen & Nincs \\
\hline D & Közmü & Magyar állami & Igen & 1 mélyinterjú \\
\hline E & Tanácsadás & Hazai kkv & Igen & 2 mélyinterjú \\
\hline F & High tech & Multinacionális & Igen & 1 mélyinterjú \\
\hline G & - & - & - & Szakirodalom \\
elemzés
\end{tabular}

Táblázat 30: Vállalati esettanulmányok összefoglalása

Forrás: saját szerkesztés

Az dolgozatok elemzésében a fő cél az volt, hogy belátást biztosítson arra, hogy milyen adaptációs stratégiával válaszolnak a marketingszervezetek arra a környezeti kihívásra, amelyet közösségi média megjelenése, terjedése jelent. 


\subsection{Elemzés}

A hallgatók számára biztosított kutatási vezérfonálban a közösségi média által indukált változások eltérő szempontjai szerepeltek, melyeket a következő táblázat foglal keretbe:

\begin{tabular}{|c|c|c|c|}
\hline $\begin{array}{l}\text { Szervezeti } \\
\text { tényezők }\end{array}$ & Képességek & $\begin{array}{l}\text { Szervezetközi } \\
\text { tényezők }\end{array}$ & $\begin{array}{l}\text { Egyéb } \\
\text { (környezeti) } \\
\text { tényezők }\end{array}$ \\
\hline Kultúra & $\begin{array}{l}\text { Általános } \\
\text { képességek }\end{array}$ & $\begin{array}{l}\text { Diszruptív } \\
\text { innováció }\end{array}$ & $\begin{array}{l}\text { Környezeti } \\
\text { hatások } \\
\text { tényezők }\end{array}$ \\
\hline Stratégia & Vezetői készségek & $\begin{array}{l}\text { Ökoszisztéma } \\
\text { szerü működés }\end{array}$ & \\
\hline Felépítés & Tudástranszfer & & \\
\hline $\begin{array}{l}\text { Marketing } \\
\text { szerepe } \\
\text { feladatköre }\end{array}$ & $\begin{array}{l}\text { Közösségi média } \\
\text { eszközök } \\
\text { használata }\end{array}$ & & \\
\hline
\end{tabular}

Táblázat 31: Esettanulmányok megírásához biztosított szempontrendszer Forrás: saját szerkesztés

\section{Az átalakulás driverei}

A fentebb felsorolt tényezők mellett egy másik érdekes szempont előkerült több munkában, amely a téma egyfajta „bevezetőjeként” szolgálhat. A hallgatók saját vállalati tapasztalataik alapján valamint az általuk megkérdezett szakértők elmondásaira építve több olyan tényezőt is bemutattak, melyek a közösségi média használatára ösztönzik a vállalatokat. Ezek a „driver”-ek különböző csoportokba sorolhatóak, úgy mint:

- Technológiai lehetőségek, fogyasztók elérésének újszerü, hatékony eszközei. „Már 50 évvel ezelött megfogalmazott igény, miszerint a hatékonyság érdekében a fogyasztókat olyan hirdetésekkel kell elérni, ami valóban érdekli öket, a multiscreening, big data és a technológiai fejlödés 
hatására mára már teljes mértékben kivitelezhető. A vállalatok az eszközök széles tárházából válogathatnak" (A).

- Vállalat magasabb szintjeiről (pl. külföldi HQ) érkező nyomás: „A döntések egy része nem itt születik, nem a magyar csapat dönti el, hogy mire mennyit forditanak. A kapott direktívákban a közösségi médiának már évek óta kiemelt helye van" $(\mathrm{O})$.

- Hatékonyabb és pontosabb mérési lehetőségek

- Költségelőny

A fenti soktényezős lista is azt mutatja, hogy komplex folyamatról van szó, de a vállalatokra több oldalról is nyomás nehezedik, hogy maguk is aktív részesei és szereplöi legyenek a közösségi médiának. A dolgozatokból csupán egyetlen olyan tényező derült ki, amely folyamat ellen hat: a szervezeti képesség hiányossága. „A korábbi vezetö még anélkül el tudta látni a feladatait, hogy tisztában lenne a legaktuálisabb digitális trendekkel" (B).

\section{Szervezeti tényezők}

A kutatási eredmények a szakirodalmi összegzéssel összhangban azt mutatják, hogy a marketing szerepe, feladatköre és szervezeti elhelyezkedése, szervezeten belüli kapcsolódásai mind megváltozóban vannak a közösségi média térnyerésével. A szervezeti tényezők vizsgálata az alábbi táblázatban közölteknek megfelelően négy különálló területre bontva történik meg: a szervezeti kultúra, stratégia, felépítés, valamint a szervezeten belül a marketing szerepe és feladatköre.

Szervezeti felépítés és feladatkörök

A marketing szervezeten belüli helyzetével kapcsolatos kérdésekre beérkezett válaszok alapján felvázolható, hogy a megkérdezésbe bevont vállalatoknál milyen módon változott a terület szervezeten belüli helyzete. (B) esetben ez plasztikusan kirajzolódik, mivel a hallgató dolgozatában részletesebben is ismertette a DSMMet megelőző valamint a jelenlegi állapotot: 


\begin{tabular}{|l|l|l|}
\hline & Korábban & Most \\
\hline Marketing osztály létszáma & 5 fö & 15 fö \\
\hline Fö cél & $\begin{array}{l}\text { „Prezentációk csinosítása”, } \\
\text { adminisztratív teendők }\end{array}$ & Stratégiai szerepkör \\
\hline Müködés közege & Offline & Offline és online \\
\hline $\begin{array}{l}\text { Vezető } \\
\text { Munkaeszközként használt }\end{array}$ & Régivágású, „offline” & $\begin{array}{l}\text { Digitális kompetenciákkal } \\
\text { rendelkező }\end{array}$ \\
\hline $\begin{array}{l}\text { Marketingosztály szervezeten } \\
\text { belüli megítélése }\end{array}$ & Támogató funkció & $\begin{array}{l}\text { Új technológiák, közösségi } \\
\text { média applikációk }\end{array}$ \\
\hline
\end{tabular}

Táblázat 32: A marketingszervezet átalakulása a "B" esetben

Forrás: saját szerkesztés

Nem mindenhol mutatható ki ilyen jelentős méreteket öltő változás, viszont az, hogy a fenti táblázat egy nagy világszerte több tízezer és idehaza is többszáz munkavállalót foglalkoztató multinacionális cégről szól, arra enged következtetni, hogy ez a jelenség nem rendkívüli. Más beszámolókban is megjelent a marketing szervezet bővülése: „Az online marketing csapat alkalmazottainak száma megnött az évek alatt, ahogyan a fókusz mind inkább erre a tevékenységre esett" (J), valamint a szervezeten belüli ,tekintély” gyarapodása: „mérés teljesen új képességeket és egy új embert is megkivánt, melynek segitségével az osztály a kiszolgáló pozíciójából sok esetben tanácsadói pozícióba lépett." (N)

A szervezetek előbb az online, majd a közösségi média megjelenésével előálló, megváltozott helyzetekre különböző válaszokat adhattak:

- meglevő struktúra átalakítása: „rugalmasabb és hatékonyabb müködést biztositó részleggé vált a marketing" (D)

- új szervezeti egységek kialakítása: „Az igazgatóságon belül megalakult egy új csoport, melynek fó célja az iparághoz kapcsolódó innovációk feltérképezése és lehetöség szerinti implementálása. A szervezet megalakulásának fontos szerepe volt abban, hogy naprakészen tartsa a CÉGNÉV-et az új technológiák ismeretében" (C) 
- feladatok kiszervezése külső szolgáltatók, ügynökségek irányába (akár stratégiai szinten is): „, a CÉGNÉV a marketingstratégia és a kommunikációs eszközök és módszerek kialakitásához tanácsadó céget bízott meg” (J)

A közösségi média nem csak a szervezeti struktúrát, de az egyes szervezeti alegységek közötti viszonyrendszert is átrendezte. A marketingosztályok más szervezeti egységek feladatait vehetik át, a kutatási jelentésekben HR (toborzás) valamint IT (online alkalmazások karbantartása) kompetenciák átszüremkedéséről számoltak be. Megváltozik a kapcsolat a külföldi központtal, és a feladatok szélesebb skálájára vesznek igénybe ügynökségi erőforrásokat.

Az új helyzetben sok cég szembesült azzal, hogy nem léteznek „best practise” forgatókönyvek, nincsenek kész válaszok: „elengedhetetlen a nyitottság az újdonságok irányába, eszközök és megoldások széles körét kell kipróbálnunk” (E). Ez - mint az a későbbiekben bemutatásra kerül - teljes mértékben összhangban van a marketingszervezet vezetőjével szemben támasztott követelményekkel is.

A marketingosztály szervezeten belül elfoglalt helyével kapcsolatban különböző trendek rajzolódnak ki a megkérdezés, illetve hallgatói beszámolók alapján. Nagyobb vonalakban ezek az irányvonalak az alábbiak:

- a marketingfeladatok szétterítődnek a szervezetben (más osztályok is olyan teendőket látnak el, melyek hagyományosan a marketing szervezetek feladatai közé sorolhatóak). A közösségi médiában rejlő potenciált nem csak a marketing osztályok vették észre, hanem más szervezeti egységek is igyekeznek kiaknázni (pl. HR osztály - toborzás), illetve más osztályok is bekapcsolódnak az ezzel kapcsolatos feladatok ellátásába (pl. IT).

A hallgatói kutatás arra utal, hogy ez a folyamat a marketing osztály részéröl érkező támogatás, segítségnyújtás mellett valósul meg: „azon feladatok, amelyek eddig zömmel a HR osztály munkáját képezték, mostanra marketing elemekkel is kiegészültek. A tanácsadás vagy az audit osztály számára készített toborzó videókat például a marketing, grafikusi segítséggel vett fel, vágott meg. Az alkotás végül kikerült a közösségi médiába is azzal a céllal, 
hogy egy modern, fiatalos vállalat képét fessék a CÉGNÉV-röl és minél több potenciális munkavállalót buzditsanak jelentkezésre” (B).

- a marketingosztály olyan más szervezeti egységekkel alakít ki szoros munkakapcsolatot, ami korábban nem volt jellemző. „a digitalizáció az informatikai osztállyal való szorosabb együttmüködést kíván meg. Egy nagyobb volumenü projekt kapcsán nem csak a lokális, de sokszor a regionális vagy globális IT-s szakemberekkel is együttmüködik a marketing osztály" (C).

- a marketing szerepe nő, feladatköre bővül, szervezeten belüli megítélése pozitívan változik: „,marketing osztály szervezeten belül betöltött helyzete megváltozott, különbözö értékesitési területek mindegyike létrehozott online egységeket” (H); „a DSMM marketing mind inkább stratégiai területté válik. A pár éve kialakitott központi marketing csapat ennek az elsö lépése volt, az idei év egyik nagy célkitüzése az, hogy az online felületeken történö eladásokat növelni tudja a CÉGNÉV Európa szerte" (F).

Ezzel ellentétes helyzet (marketing osztály fontosságának csökkenése, stagnálása, marketing háttérbe szorulása) olyan vállalatoknál volt megfigyelhető, ahol a magyarországi marketingcsapat a külföldi HQ alárendeltjeként csupán a máshol meghozott döntések puszta végrehajtója / felügyelője.

Látható, hogy a marketing osztályok bővülését változatos szervezeti struktúrák mellett valósítják meg a vállalatok. Erre azért is szükség van, mivel nem csak létszámban, de az ellátott feladatok mennyiségében, fajtájában is növekedésről számoltak be a kutatásba bevont cégek. „A DSMM megjelenése elött lényegében elhanyagolható volt a CÉGNÉV marketingtevékenysége, csakis müködésére koncentrált a vállalat, a fogyasztó orientáltsága a hibátlan szolgáltatásból állt, a kommunikáció nem volt része. Ennek következtében a korábban szerény létszámú marketingosztályát is bövitenie kellett" (D).

A kutatási jelentésekben a marketing új feladatai közül néhányról részletesebb szó $\operatorname{esett}(\mathrm{N}),(\mathrm{H}),(\mathrm{B})$ : 


\begin{tabular}{|c|c|c|}
\hline Új feladat & $\begin{array}{l}\text { Mely } \\
\text { „hagyományos" } \\
\text { területhez hasonlít }\end{array}$ & $\begin{array}{l}\text { Legfontosabb eltérések a } \\
\text { „hagyományos” területhez képest }\end{array}$ \\
\hline $\begin{array}{l}\text { Folyamatos } \\
\text { tartalomgyártás, } \\
\text {-szolgáltatás }\end{array}$ & PR & $\begin{array}{l}\text { Felgyorsult munkavégzés } \\
\text { Hatványozottan } \\
\text { munkamennyiség } \\
\text { Szöveges elemek mellett kiemelt } \\
\text { szerep jut a képi és videós } \\
\text { tartalmaknak }\end{array}$ \\
\hline $\begin{array}{l}\text { „Influencerek" } \\
\text { bevonása a } \\
\text { marketing } \\
\text { tevékenységbe }\end{array}$ & $\begin{array}{l}\text { Sztárok, } \\
\text { márkanagykövetek } \\
\text { alkalmazása }\end{array}$ & $\begin{array}{l}\text { 1-1 nagy eléréssel rendelkező sztár } \\
\text { helyett sok kisebb eléréssel } \\
\text { rendelkező influencer } \\
\text { Sztárok: professzionális, tapasztalt } \\
\text { külső szerződő partnerek. } \\
\text { Influencerek: „lelkes amatőrök” } \\
\text { Sztárok: fizetés föként pénzben, } \\
\text { influencernél fizetés akár } \\
\text { termékcsomaggal }\end{array}$ \\
\hline Online mérés & Hagyományos mérés & $\begin{array}{l}\text { Adatszolgáltatás, külső mérések } \\
\text { helyett saját adatok használata } \\
\text { Alkalmankénti mérés helyett } \\
\text { folyamatos mérés (valós időben } \\
\text { frissülő adatok) } \\
\text { Fogyasztók személyes jellemzőinek } \\
\text { pontosabb nyomon követése } \\
\text { Az új adatok összevetése a } \\
\text { hagyományos csatornákról érkező } \\
\text { információkkal külön feladatot } \\
\text { jelent. }\end{array}$ \\
\hline
\end{tabular}

Táblázat 33: A marketingosztályok új feladatai

Forrás: saját szerkesztés 
De felmerültek olyan új típusú feladatok is, melyeknek nem feleltethető meg korábbi tapasztalat: az online közösségek menedzsmentje, a nagy volumenủ adatok karbantartása, menedzselése és prezentációja.

A szervezeti átalakulás egy negatív velejárójaként szerepelt több kutatási jelentésben is az, hogy az új, megváltozó helyzet belső konfliktusokat szül. Több beszámoló is érkezett, ami arra enged következtetni, hogy az online világ becsatornázása a céges folyamatokba nem mindenhol volt zökkenőmentes. Ennek a konfliktusnak az intenzitása az online marketing különálló osztályba történő át/kiszervezéstől a szervezeten belüli diszharmóniáig vázolható fel: „az online csapat vezetösége nem a marketing igazgató alá tartozott közvetlenül, hanem azzal párhuzamosan müködött.” (J). „Az online marketing vezetöje szerint sok a konfliktus, aminek egyik forrása az, hogy az online csapat modernebb. A feladatokat ugyanis be kell mutatni a marketing osztálynak, akik csak egyszerü kreatívokkal dolgoznak" $(\mathrm{H})$.

\section{Szervezeti kultúra}

Érdekes tény a kutatások kapcsán, hogy több kutatási jelentésben is az egyik legbővebben tárgyalt rész pontosan a közösségi média szervezeti kultúrát érintő aspektusai voltak, igaz, ezek néhány kategóriával lefedhető verziókban érkeztek. A beszámolók szerint volt, ahol megváltozott a kultúra és volt, ahol nem a DSMM eszközök bevezetésével párhuzamosan.

Ahol a kultúra változatlanságáról számoltak, ennek különböző okai lehettek:

- a meglevő, merev szabályok miatt: „Egy nagy szervezet nagyobb hangsúlyt fektet a meglevö piaci pozíciók védelmére. A CÉGNÉV-nél a vezetési stílus tekintélyelvü (,,az van, amit a fönök mond”), nem úgy, mint más szervezeteknél, hogy a munkavállalókat is bevonják a döntési folyamatokba. Ez a szervezeti kultúra szinte állandó, bár a környezeti kihívások miatt a CÉGNÉV-nek ezen a területen is megújulásra lehetne szüksége. A felsővezetés határozottan képviseli azt az álláspontot, hogy nem viselkedhet egy ekkora szervezet felfedezöként a hazai és a nemzetközi piaci 
pozíciójának védelme miatt. Nem lehet „kreatívkodni”, a külföldi $H Q$ útmutatásait kell követni” $(\mathrm{H})$

- a vállalati kultúra eleve nyitott, támogató volt, ami a $\mathrm{KM}$ alkalmazások „terjedésének kedvezett” (M).

Többen is jelezték, hogy bár a kultúra nem változott, annak megváltoztatása szükséges lenne, vagy a vezetőséget is foglalkoztatja a kérdés: „, a DSMM marketing sikerességének növeléséhez mindenképpen szükség lenne a szervezeti kultúra megváltozására, a nyitottabb gondolkodásmódra" (I). Ez azonban nem egyszerü kérdés, szintén a beszámolókból tudni, hogy ahol megpróbálták, ott is esetenként jelentős szervezeti ellenállásba ütközött ez a kísérlet: „Érezni lehetett, hogy a kultúrát és a vállalati szereplök , közérzetét” egy fiatalosabb és modernebb irányba akarták elmozdítani. Ez többször mesterkélten és eröltetettnek hatott” (J). Az ellenállás a különböző szervezeti egységeknél eltérő intenzitású és irányú lehet: „üzletágak eltérő mértékben nyitnak a változások felé, melyek elöl jellemzöen a könyvvizsgálati üzletág zárkózik el a leginkább” (B).

A merev, zárkózott kultúra egyik következményeként tálalta az egyik kutatás azt, hogy a saját vállalata nem „érti”, hogy miről „szól” a közösségi média: „,közösségi média felületeit az egyirányú kommunikációra használja a fogyasztóval. Nem ragadja meg a lehetöséget, hogy munkatársait és a márka fogyasztóit közösségbe szervezné" $(\mathrm{N})$.

\section{Képességbeli tényezők}

A szakirodalom (ld. Felix et al. (2015), Leeflang et al. (2014), stb) alapján teljesen világos, hogy a közösségi média új marketing- és egyéb képességek meglétét állítja követelményként a szervezetek elé. A kutatásban 3 nagyobb témakör szerepelt, amely ezeket a megváltozott képességeket vizsgálta:

- Szervezeten belüli képességek, amely külön bontva: általános és vezetői képességekként kerültek kiértékelésre

- A témához szorosan kapcsolódó, közösségi média eszközök használatára vonatkozó képességek és tudás 
- Valamint a képességek átadását, megosztását vizsgáló tudástranszfer

\section{Szervezeten belüli képességek}

A fenti változások természetesen a marketingképességek szintjén is lecsapódtak. A marketingszervezeteknek újfajta tudással rendelkező munkavállalókat kell alkalmazniuk, a meglevő tudást pedig új keretek közt kell felhasználni.

\begin{tabular}{|c|c|c|c|}
\hline $\begin{array}{l}\text { Informatikai } \\
\text { képességek }\end{array}$ & $\begin{array}{l}\text { Müvészi } \\
\text { képességek }\end{array}$ & $\begin{array}{l}\text { Marketing } \\
\text { képességek }\end{array}$ & $\begin{array}{l}\text { Analitikai } \\
\text { képességek }\end{array}$ \\
\hline $\begin{array}{l}\text { Kereső } \\
\text { optimalizálás } \\
\text { PPC marketing } \\
\text { Adatbázis } \\
\text { létrehozása }\end{array}$ & $\begin{array}{l}\text { Kreatív szövegírás } \\
\text { Grafikai, } \\
\text { videószerkesztési, }\end{array}$ & $\begin{array}{l}\text { Közösségi } \\
\text { média } \\
\text { marketing }\end{array}$ & $\begin{array}{l}\text { Elemző szoftver és } \\
\text { alkalmazások (pl. } \\
\text { Google Analytics) } \\
\text { „Big data” és } \\
\text { adatvizualizáció }\end{array}$ \\
\hline
\end{tabular}

Táblázat 34: Szervezeten belüli képességek

Forrás: saját szerkesztés

A feldolgozott adatok alapján nem egyértelmü, hogy a cégek az új képességeket mely szervezeti egységben helyezik el. Van arra utaló jel például, hogy a marketing osztály munkavállalóitól informatikai képességeket várnak el: „A marketingeseknek, mint IT szakembereknek is helyt kell állniuk. Különbözö online katalógusok szerkesztésénél, összeállitásánál is számít rájuk a szervezet. A weboldalak frissitése is az ö hatáskörük alá tartozik. Felvételüknél elvárás, hogy kezelni tudják a különbözö képszerkesztö és webes felületeket.” (I)

A megváltozott helyzet új képességeket, valamint a meglevő (régi) képességek átalakítását egyaránt igényli. A dolgozatok alapján három csoportba (operatív müködés, informatikai, valamint mérés) tartozó kihívások kerültek beazonosításra, melyet ezek eltérő típusú képességek, melyeket az alábbi táblázat foglal össze: 


\begin{tabular}{|c|c|c|c|c|c|}
\hline \multicolumn{2}{|c|}{ Operatív müködés területe } & \multicolumn{2}{|l|}{ Informatika területe } & \multicolumn{2}{|l|}{ Marketing területe } \\
\hline Kihívás & Képességek & Kihívás & Képességek & Kihívás & Képességek \\
\hline $\begin{array}{l}\text { Adatvezérelt müködés } \\
\text { és fejlesztés }\end{array}$ & $\begin{array}{l}\text { - Új menedzsment } \\
\text { megközelítés }\end{array}$ & $\begin{array}{l}\text { UX (felhasználói } \\
\text { élmény tervezés) }\end{array}$ & $\begin{array}{ll}\text { - } & \text { Grafikusi } \\
& \text { képességek } \\
\text { - } & \text { Programozás } \\
\text { - } & \text { Webszerkesztés }\end{array}$ & $\begin{array}{l}\text { Kampányok } \\
\text { eredményességének } \\
\text { monitorozása }\end{array}$ & $\begin{array}{l}\text { - Statisztikai- } \\
\text { analitikai } \\
\text { képességek } \\
\text { - Eszköz ismeret } \\
\text { (pl. Google } \\
\text { Analytics, } \\
\text { Facebook } \\
\text { insights) }\end{array}$ \\
\hline Ügyfélszolgálat & $\begin{array}{l}\text { - Eszközhasználat } \\
\text { (pl. online } \\
\text { csatornák) } \\
\text { - Kommunikációs } \\
\text { stílusváltás }\end{array}$ & $\begin{array}{l}\text { Új fizetési módozatok } \\
\text { integrálása (pl. Apple } \\
\text { Pay) }\end{array}$ & - IT know-how & & \\
\hline
\end{tabular}




\begin{tabular}{|c|c|c|c|c|c|}
\hline \multicolumn{2}{|c|}{ Operatív müködés területe } & \multicolumn{2}{|c|}{ Informatika területe } & \multicolumn{2}{|c|}{ Marketing területe } \\
\hline Kihívás & Képességek & Kihívás & Képességek & Kihívás & Képességek \\
\hline $\begin{array}{l}\text { Új hirdetői } \\
\text { gondolkodás }\end{array}$ & $\begin{array}{l}\text { - Időmenedzsment } \\
\text { - "Ezerféle site, } \\
\text { ezerféle rendszer, } \\
\text { ezerféle formátum" } \\
\text { (D) kezelése }\end{array}$ & & & & \\
\hline Értékesítés & $\begin{array}{l}\text { - Ügyfél } \\
\text { kommunikáció } \\
\text { közösségi médián } \\
\text { keresztül }\end{array}$ & & & & \\
\hline
\end{tabular}

Táblázat 35: Szervezeti képességek és kihívások

Forrás: saját szerkesztés 
A táblázatból kiderül: a vizsgálatba bevont vállalatok alapvetően két irányból közelítették meg a tárgyalt kihívást. Látszik, hogy egyrészt informatikai problémákat látnak maguk előtt, melyet a szervezet informatikai képességeinek fejlesztésével, valamint mérnöki illetve kvantitatív tudományokban jártas munkavállalók felvételével igyekeznek kielégíteni. „Új szakértelemre van szükség: marketing mérnökök vagy analitikai készséggel rendelkezö marketingesekre van jelenleg szükség. Ennek eredménye a marketing szakma racionálisabbá válása. A müködésben ugyanakkor nincs változás: tények és intuitiv megérzés elegyéröl beszélhetünk. Azaz a marketingen belül a sarokpontok nem változtak, a piac visszajelez, hogy hogyan dolgoznak a munkatársak” (H). „a mai marketing csapatokban már nem pusztán kommunikáció és marketing végezettségü emberek kerülhetnek be, hanem akár mérnökök, grafikusok és ,,adat guruk” is” (B).

A mérés bonyolultságát jelzi, hogy egyes beszámolók szerint azok összeállítását több szervezeti osztály közösen végzi: „a riportkészítés során az üzleti terület megfogalmazza az méréssel kapcsolatos elvárásokat, az IT terület létrehozza szükséges adatpiacot, az elemzés elkészíti az üzleti igényeknek megfelelő riportot" (C).

A másik nagy terület a kommunikáció, amivel kapcsolatos elvárásbeli változások szintén különböző helyeken bukkannak fel. Kommunikációs stílusváltást várnak a cégek az ügyfélszolgálaton dolgozóktól (,„újfajta dolgozói készségek kifejezetten az ügyfélszolgálat munkavégzésében jelentek meg, akiket oktatni kellett az elektronikus felület funkcióiról" (D)) és más olyan munkakörökben, amelyek közvetlenül érintkeznek a vevőkkel - így például az értékesítőktől is (,,ügyfélszolgálati és értékesitési csapatba olyan emberek kellettek, akik képesek voltak a vállalat kultúrájának és értékeinek, valamint a reputációjának megfelelöen reagálni a kommentekre, kérdésekre és esetlegesen a támadó hangvételü üzenetekre" (J)).

A megkérdezett vállalatok válaszai alapján az ábrázolódik ki, hogy a cégek a fogyasztói vásárlási döntési út megváltozását észlelik: „korábbi tömegmédiában történö hirdetések, majd a helyszínen vásárlásra bíró ösztönzök már nem bizonyulnak elegendönek, az értékesitési út ennél jóval komplexebbé vált" (I). 
Többen erre alapozva fogalmazták meg a vezetőkkel szemben a megváltozott körülmények között támasztott elvárások és készségek listáját.

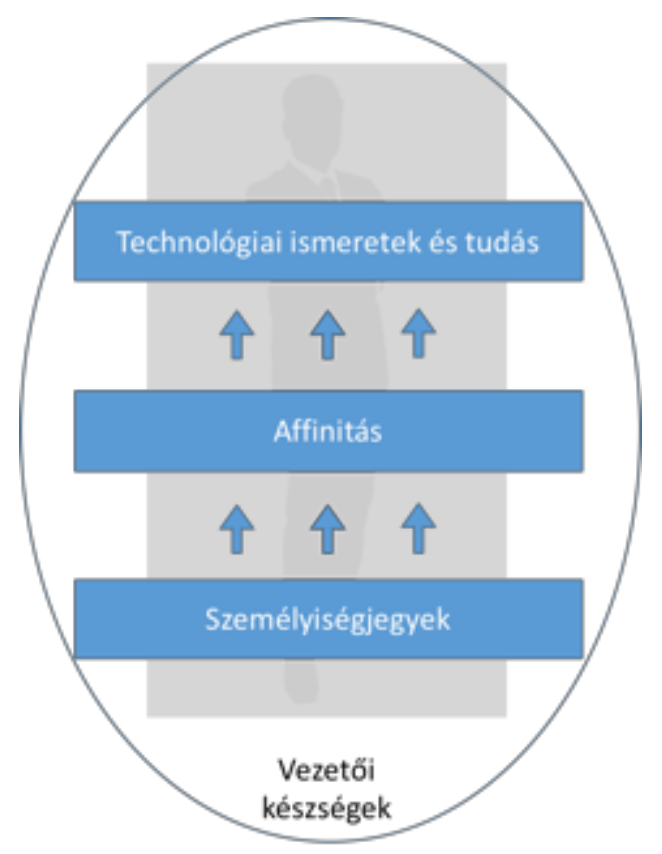

\section{Ábra 25: Vezetői készségek}

Forrás: saját szerkesztés

A kutatási jelentésekben két vezetőtípus is vizsgálatra került: az egyik egyfajta általános marketingvezetőként határozható meg, akinek a feladatai közt digitális területekkel kapcsolatos teendők is megjelennek. A másik kifejezetten digitális marketing területért felelős vezető. A kettő között vannak ugyan eltérések, de most a közös pontokra koncentrálva lesznek ismertetve az eredmények. A beszámolók alapján egy olyan kép rajzolódott ki az elvárt vezetői készségekről (ld. fenti ábra), ahol az alapvető személyiségi jegyek valamint meghatározott területek iránti affinitás a vezető szakterülete által megkövetelt technológiai ismeretekben és tudásban is manifesztálódik, és az egészet a személyes vezetői készségek foglalják keretbe.

A személyiségi jegyek ugyan nem képezték a kutatás tárgyát, több beszámoló alapján is alapvető fontossággal bírnak abban, hogy a megváltozott, illetve: folyamatosan változó körülmények, külső-belső környezeti tényezők mellett sikerrel tudjon valaki marketingcsapatot vezetni. A megemlített jellemvonások 139 
mindegyike a nyitottsággal, optimista világlátással hozható kapcsolatba, ami valószínűsíthetőleg a turbulens környezeti adottságokkal állhat összefüggésben: olyan tényezőket soroltak fel a dolgozatok, mint a nyitottság, gyors tanulásra való képesség, vagy az, hogy a vezető „,közösségi ember” legyen.

A gyorsaságot - akár tanulásban, akár döntéshozatalban - a legtöbb dolgozat valamilyen formában megemlítette, mint a vezetőkkel szemben támasztott kihívás, igény. „Volt példa arra, hogy csupán pár hét állt rendelkezésre egy új kampány összeállitására. Ilyen esetben rengeteg ember összehangolt gyors munkájára van szükség, ahol az egyes csapatok vezetőinek a koordinációs és döntéshozatali képességén sok múlik” (J). Ez a szempont egyben egy olyan témát is felvet, ami további kutatás fókuszában állhat.

A személyes affinitások kapcsán írt beszámolók két irányba mutattak:

- Technológiai nyitottság és érzékenység (,,a vezetőnek jelen kell lennie az online térben", $(\mathrm{H})$ )

- Fiatal generációk igényeire való fogékonyság

A technológiai affinitás, valamint a fiatalabb generációk felé fordulás egyik következménye lehet a közösségi média eszközök alkalmazása a vezető szakmai munkája során. A döntéstámogató rendszerek többsége mára képessé vált a közösségi médiából érkező adatok fogadására és feldolgozására. De emellett a vezetőnek fontos legalább fogalmi szinten tisztában lennie a konkrét közösségi média alkalmazásokkal is. Erre mind a stratégia kialakításában, mind a beosztottak munkájának napi irányításában és felügyeletében is szüksége van.

A hallgatói kutatásokból megismert vezetői készségeket a korábbiakkal összhangban a gyorsan változó, dinamikus, turbulens környezet által támasztott igényekkel lehet párhuzamba állítani. Olyan tényezők kerültek említésre, mint a rugalmasság, gyors reagáló képesség, projektmenedzseri készségek, analitikus készségek vagy a környezeti változáshoz való adaptáció képessége.

A fentiek alapján a lenti ábra az alábbi módon egészíthető ki a kutatásban megállapított tényezőkkel: 

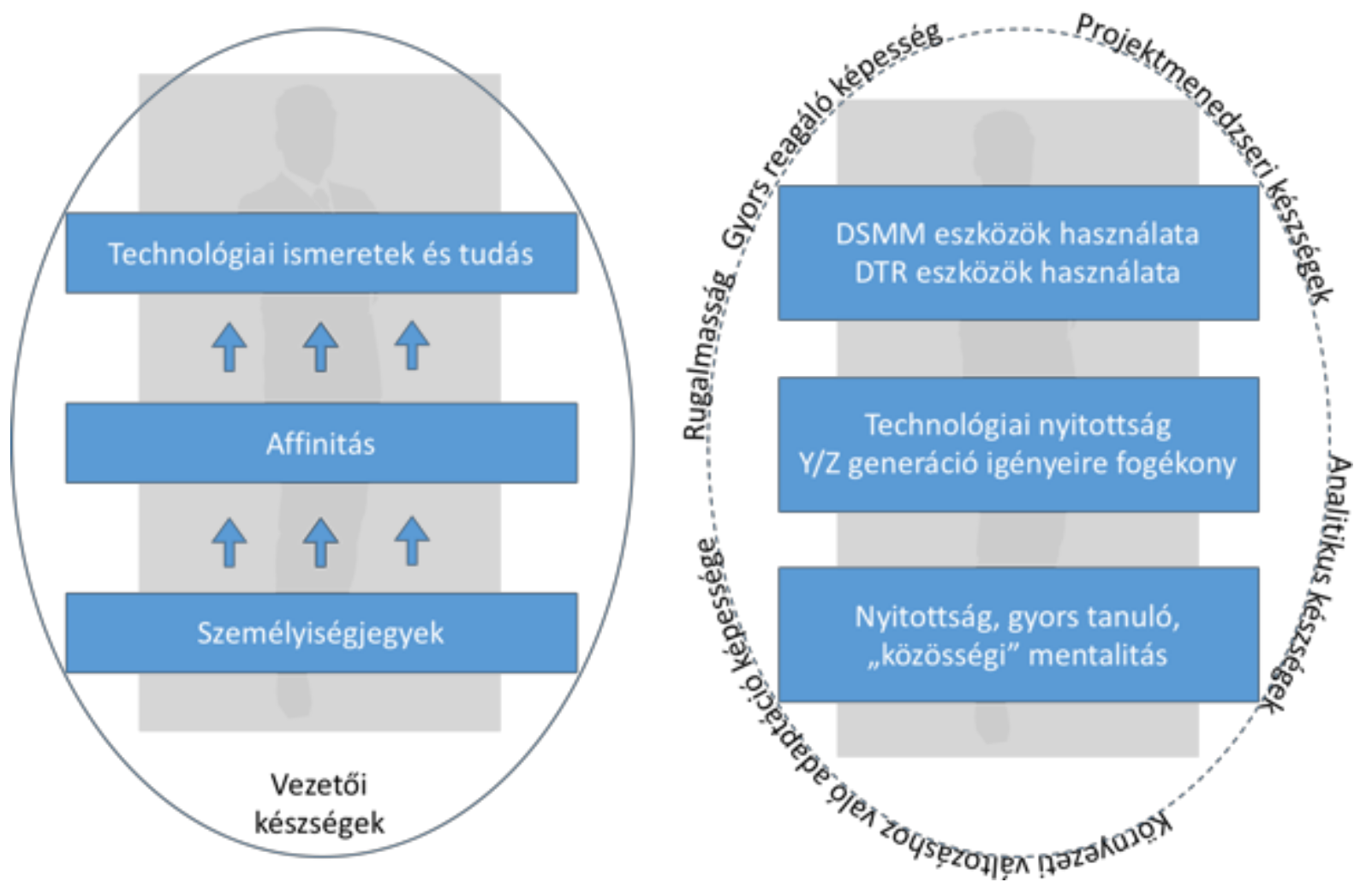

\section{Ábra 26: Vezetői készségek változása}

Forrás: saját szerkesztés

Végül egy érdekes, de ellentétes irányba mutató tényezőre is fontos ráirányítani a figyelmet. A kutatásból fény derült arra: az eddig megfogalmazottakkal ellentétben vannak olyan vállalatok is, ahol a digitális készségekkel kapcsolatos elvárások még nem szüremkedtek be vezetői szintre. „a vállalat vezetésében a digitalizáció részben kap helyet, a döntéstámogató rendszerek révén - ám egyéb módon ez még nem jelenik meg" (N). Ennek különböző okai lehetnek, például iparági helyzet, a vállalat mérete, a konkrét esetben a külföldi központtól kapott direktíva valamint az érintett vállalat marketingvezetőjének személyes készségbeli hiányosságai miatt volt tapasztalható ez a helyzet.

\section{Közösségi média eszközök használatára vonatkozó képességek és tudás}

A közösségi média alkalmazások használatával kapcsolatban élesen elkülöníthető a stratégiai („,mire használjuk”) és az operatív („,hogyan használjuk”) jellegű tudás. Érdekes módon a „stratégiából levezetett napi gyakorlat” jellegű működés nem szükségszerüen jellemzi a vállalatokat ezen a téren: „ezeket a platformokat már 141 
évek óta alkalmazza a cég, de körülbelül egy éve rendelkezik tudatosan felépített közösségi média stratégiával" (B). Ez egyszerre utal arra, hogy kezdetekben a vállalatok legalább egy része nem tulajdonított stratégiai jelentőséget a KM alkalmazások használatának, és arra is, hogy mára ez a helyzet már változóban van.

A kutatási jelentésekből érdekes kép rajzolódott ki arról, hogy a vállalatokon belül a marketing mellett men osztályok rendelkeznek hozzáféréssel a közösségi platformokhoz, és melyek azok, amelyek aktívan használják azokat:

- A cég valamennyi alkalmazottja: ,jelentkezett rá az igény, hogy ne csak a marketing csapat tagjai használják, hanem a cégen belül mindenki tudatosan kezelje ezeket a felületeket” (B). „Egy olyan kisvállalatnál, mint a CÉGNÉV, mindenki marketinges. A közösségi média korában minden munkavállaló minden bejegyzésével, fotójával a vállalatot is képviseli” (E)

- IT osztály: „digitalizáció az informatikai osztállyal való szorosabb együttmüködést kíván meg” (B)

- HR: ,a közösségi oldalakra ugyanúgy kikerülnek az aktuális pozíciók” (J); „a HR a nyitott pozíciókat a Linkedin-en keresztül is népszerüsíti, valamint felhívja a figyelmét a munkavállalóknak, hogy osszák meg ezeket a pozíciókat” (A); „Idővel a munkaerőtoborzás jelentős része is inkább közösségi médián keresztül zajlott” (L)

- Felsővezetés: „a cég első hirdetését az ügyvezető igazgató adta fel Facebookon egy csapatépítő tréningre tartva a vállalati buszon. A lehetőségeket végig pörgetve ott helyben döntötte el, hogy ezt az eszközt az értékesítőknek használniuk kell” (K)

Ezzel összevetésben nem meglepö, hogy a közösségi média oldalak a marketingkommunikáció mellett más célokat is szolgálnak. Különösen fontosnak tünik a marketingmérés kérdésköre, amit gyakorlatilag valamennyi kutatási jelentés érintett. ,A CÉGNÉV jelenleg öt közösségi média oldat tart fent, konkrét stratégia és KPI-ok mentén figyelem arra, hogy milyen közönséget milyen tartalommal és mikor akar elérni” (B). Igaz, többen a nehézségeket is megfogalmazták: „az 
engagement magas értékei eladásban végzödnek, ám ennek a konverziónak a mérésére, és így a ROI kiszámitása nehézkes" (N).

Érdemes végül megjegyezni, hogy miként az előző alfejezetben is történt rá utalás, itt is volt arra utaló jel, hogy egyes cégeknél a KM alkalmazása még most sem érte el a vezetői szintet: „DSMM elötti környezethez képest nincs jelentős változás a CÉGNÉV életében" (D).

\section{Tudástranszfer}

Több, a kutatásba bevont vállalat is rendelkezett szervezett keretek közt zajló olyan programokkal, amely kifejezetten a közösségi média alkalmazások használatával kapcsolatos ismeretek cégen belüli disszeminációját célozta. „Nemrégiben indult egy belsö képzés, amely során négy külsö szakértö, több héten keresztül, négy különbözö témában tart workshopokat" (B). Volt, aki utalt arra, hogy a felsővezetés úgy észleli, hogy ezt az alkalmazottak is elvárják: „az újitások, a folyamatfejlesztések a szervezet munkavállalóit kihívások elé állithatják. Fontos, hogy a vezetök felismerjék a helyzetet, és biztositják beosztottjaik számára a megfelelö tréningeket, melyek segítségével képesek lesznek az új ismeretek elsajátitására." $(\mathrm{K})$

A dolgozatokban bemutatott képzések nem csak a KM alkalmazások felhasználói szintü kezelésével kapcsolatos tudásanyagot osztott meg, hanem egyéb, üzleti szempontból kritikus fontosságúnak ítélt ismeretet is megosztott. A különböző képzések témái az alábbi csoportokba oszthatóak:

- Big data (elemzés, adatkezelés, adatvezérelt döntés, stb)

- Diszruptív innováció illetve jövőben várhatóan elterjedő technológiákkal kapcsolatos ismeretek (pl. mestersége intelligencia, robotika, kriptovaluták, $\mathrm{stb})$

- Tartalomgyártás (kreatív írás, szerkesztés, stb)

- Adatvédelem (aminek aktualitását a dolgozat szerint az EU által tárgyalt és elfogadott GDPR „csomag” adta) 
A közösségi média alkalmazások azonban más módon is kapcsolódnak a tudástranszfer témájához. Egyes vállalatoknál ezek a platformok maguk is az ismeretátadás eszközeivé váltak: „amennyiben információra van szükségünk, több kommunikációs csatorna is rendelkezésünkre áll a hagyományos telefonos segítség mellett" (K).

Végül kiemelendő, hogy a tudás nem csak szervezeten belül, hanem az elvégzett kutatások alapján szervezetek között is áramlik, aminek az eszköze lehet munkavállalók átcsábítása, de akár a versenytársak megfigyelése is. Több beszámoló is érkezett arról, hogy a vállalatok szorosan figyelemmel követik a hasonló profilú cégek közösségi médiabeli tevékenységét. ,Mindenki értékelte és látta, hogy a nagy versenytársak hogyan csinálják és kezelik ezt a területet” (J).

\section{Szervezetközi tényezők}

Korábban láttuk, hogy a közösségi média a szervezetközi kapcsolatokat is átformálja (Hult-Morgan, 2015; Hanna et al., 2011; stb). Az elvégzett kutatómunka alapján két olyan irány állapítható meg, amely a vállalatok egymással való kapcsolódását átalakíthatja: a diszruptív innováció folyamata valamint a korábban ismertetett ökoszisztéma szerü müködés (Adner, 2017).

A kutatásba bevont több vállalat is jelezte, hogy a közösségi médián keresztül lebonyolított ügyfélszolgálat jellegü feladatokat már most igyekeznek minél szélesebb körüen mesterséges intelligenciára bízni. „mesterséges intelligencia, mely romboló innovációnak tekinthetö, a chatbot formájában jelent meg a CÉGNÉV-nél” (B). Máshol az erre vonatkozó szándék érhető tetten: „Az ügyfélszolgálatot chatbot alkalmazásával valósitanánk meg” (E). Ez jellemzően olyan feladat, melyet korábban belső erőforrásból oldottak meg vagy külső szolgáltatók (ügynökségek) segítségét igényelték.

A vállalatok - érthető módon - saját tevékenységük (termékeiket, általuk kínált szolgáltatásokat) fenyegetettségét is megélik, amikor a közösségi média diszruptív hatásairól voltak kérdezve. Ezzel kapcsolatban három attitűd figyelhető meg:

- Reálisnak tekintett fenyegetés, a megoldást még keresik 
- A cég találkozott a fenyegetettséggel, de úgy érzi: sikerrel megoldották a helyzetet: „az internetes felület kialakitása és müködtetése megölte a papir alapú kiadványt, saját terméküket, amelyre a cég létrejött, mégis az új platform fejlesztése kiváló döntésnek bizonyult, az oldal népszerüsége jócskán felülmúlja a könyvét" (M)

- A cég kifejezetten egy diszruptív innovációs ötlet megvalósítására jött létre: „Diszruptív innováció magában a szektorban fedezhető fel mintsem a CÉGNÉV marketingfolyamataiban. A múltban jellemzöen személyes megjelenést igénylö kurzusokon vettek részt az emberek (pl. magántanárhoz jártak), addig az elmúlt évek során ez egyre inkább eltolódott az online oktatás irányába" (L)

\section{Egyéb környezeti tényezők}

Végül a vállalat és szükebb-tágabb környezete kapcsolódásában is transzformáló hatással bír a közösségi média. Az ezzel kapcsolatos beszámolókban leggyakrabban a gyors reakcióképességet, folyamatos környezeti változást és az ahhoz való adaptáció képességét emelték ki. „A digitális átalakulás az eddiginél sokkal gyorsabb alkalmazkodást követelt meg a CÉGNÉV-töl is. Az ügyfelek, a potenciális munkavállalók az információkhoz már sokkal gyorsabban akartak hozzájutni.” (B)

A kutatási eredmények alapján egy komplexebb, a piaci szereplők számában valamint fajtájában is proliferálódó környezet képe rajzolódik ki. „Van változás a környezeti feltételekben, nehezebb a médiatervezés, összetettebb lett a folyamat, több munkába és több pénzbe kerül az anyag-elöállítás" (H). Ez pedig a szervezetek adaptációs képességét teszi próbára - ami pedig visszavezet az alapkérdéshez, vagyis a szervezet formálódásához, átalakulásához.

\subsection{Következtetések}

A kutatás második fázisának célja volt, hogy segítsen megérteni a cégek stratégiai válaszát a közösségi médiával jellemezhetö, megváltozott környezetben. A hallgatói kutatásokban feltárt fontosabb szempontokat valamint az azokból levont következtetéseket a 36. táblázat tartalmazza: 


\begin{tabular}{|c|c|}
\hline Tényező & Következtetések, fontosabb kutatási megállapítások \\
\hline Átalakulás driverei & $\begin{array}{l}\text { A nyilvánvaló költségelőny mellett a technológiai } \\
\text { lehetőségek kihasználása, fogyasztók elérése valamint a } \\
\text { (külföldi) HQ-ból érkező direktívák is szerepet játszanak a } \\
\text { magyarországi vállalatok KM marketing tevékenységének a } \\
\text { bővülésében }\end{array}$ \\
\hline \multicolumn{2}{|l|}{ Szervezeti tényezők } \\
\hline Kultúra & $\begin{array}{l}\text { A vállalati kultúra támogató vagy elutasító lehet a KM } \\
\text { használattal szemben. A merev szervezeti kultúrával } \\
\text { rendelkező cégeknél egy kultúraváltás jelentős szervezeti } \\
\text { ellenállásba ütközhet, melynek mértéke/iránya szervezeti } \\
\text { egységenként eltérő lehet. }\end{array}$ \\
\hline Stratégia & $\begin{array}{l}\text { A KM stratégiai szerephez jutását a vállalatok nem látják } \\
\text { indokoltnak (szemben például a ,hagyományos” online } \\
\text { marketinggel). De több szervezetnél beszámoltak KM } \\
\text { stratégia gyártásáról }\end{array}$ \\
\hline Felépítés & $\begin{array}{l}\text { A KM megjelenése miatt több vállalatnál újra-/átszervezték a } \\
\text { marketingosztályok felépítését. Átalakul a kapcsolat más } \\
\text { szervezeti egységekkel. A KM megjelenése új } \\
\text { feszültségforrást jelenthet a „hagyományos” és az „úu” } \\
\text { marketingegységek között. }\end{array}$ \\
\hline $\begin{array}{l}\text { Marketing szerepe és } \\
\text { feladatköre }\end{array}$ & $\begin{array}{l}\text { Marketing feladatok jelennek meg más szervezeti } \\
\text { egységekben, a marketing is olyan feladatokat vállal, ami } \\
\text { hagyományosan nem tartozott a teendői közé. }\end{array}$ \\
\hline \multicolumn{2}{|l|}{ Képességek } \\
\hline Általános képességek & $\begin{array}{l}\text { Új típusú képességek megszerzésére van szüksége a } \\
\text { szervezeteknek, és a }\end{array}$ \\
\hline Vezetői készségek & $\begin{array}{l}\text { A vezetők személyes affinitása is meghatározó lehet (pl. KM } \\
\text { iránti érdeklődés, személyes KM használat) }\end{array}$ \\
\hline Tudástranszfer & $\begin{array}{l}\text { A cégek szervezett formában segítik a KM-val kapcsolatos } \\
\text { tudásanyag szervezeten belüli disszeminációját. A KM akár a } \\
\text { tudásmegosztás egyik eszköze is lehet }\end{array}$ \\
\hline
\end{tabular}




\begin{tabular}{|l|l|}
\hline Tényezö & Következtetések, fontosabb kutatási megállapítások \\
\hline $\begin{array}{l}\text { Közösségi média eszközök } \\
\text { használata }\end{array}$ & $\begin{array}{l}\text { Külön válik a „hogyan”és a „mire” használjuk kérdése. Nem } \\
\text { csak a marketing osztály, de akár a cég valamennyi } \\
\text { munkavállalója számára „feladat” lehet a KM jelenlét } \\
\text { gondozása, segítése }\end{array}$ \\
\hline Szervezetközi tényezők & $\begin{array}{l}\text { A cégek fenyegetésként élhetik meg az általuk kínált } \\
\text { szolgáltatás/termék KM által történö „kiváltását” (azaz } \\
\text { megszűnését). Egyes cégek a helyzetet felismerve sikeresen } \\
\text { mentették át az alaptevékenységet a KM-ra }\end{array}$ \\
\hline $\begin{array}{l}\text { Egyéb (környezeti) tényezők } \\
\text { Környezeti hatások és } \\
\text { tényezök }\end{array}$ & $\begin{array}{l}\text { vállalat és szükebb-tágabb környezete kapcsolódásában is } \\
\text { transzformáló hatással bír a közösségi média. A sikeres } \\
\text { adaptáció kulcsaként több szervezet is a gyors alkalmazkodó } \\
\text { és reagáló képességet jelölte meg }\end{array}$ \\
\hline
\end{tabular}

Táblázat 36: Vállalati esetekben feltárt fontosabb szempontok

Forrás: saját szerkesztés

\section{Kutatás harmadik fázisa: álláshirdetés adatbázis elemzése}

\subsection{Adatgyújtés}

Az adatok Magyarország egyik vezető álláshirdetési portáljáról, a profession.hu-ról származnak. Az oldalt 2002-ben alapították, nem sokkal később egy multinacionális vállalat vásárolta fel, jelenleg a világ piacvezető állásportáljait tömörítő nemzetközi szervezetnek, a [The Network]?-nek a tagja. Az oldalon az éppen aktuális álláshirdetések érhetőek el, a korábbi évek álláshirdetései az archive.org ,internetarchívum” szolgáltatás használatával váltak elérhetővé13.

${ }^{13}$ Kiindulópont: https://web.archive.org/web/*/profession.hu 
Az adatgyüjtést megbízási díj fejében diákok végezték, akik az alábbi útmutatót követték:

1. Nyissák meg az archive.org-ot, keressék meg a profession.hu oldalt, majd a „The wayback machine” szolgáltatás segítségével nyissanak meg minden évet 2010-17 között

2. Az adott év június vagy július hónapjában nyissanak meg egy dátumot (azért az év közepéröl történt választás, hogy a lehető legkevesebb átfedés legyen az évek között)

3. Mentsék le az adott dátumról valamennyi hirdetést, amely a „Marketing” kategórián belül jelent meg. Az adatbázis építésében az alábbi fő szempontokat mentették le:
a. Pozíció megnevezése
b. Hirdető vállalat neve
c. Pozíció rövid leírása
d. Állás betöltésének a helye
e. Álláshirdetés közzétételének az időpontja
f. Pozíció hosszú leírása

Az utolsó, 2018-as év adatgyüjtése közvetlenül a profession.hu-ról történt, a 2018 március 4-i állapot szerint tükrözte a „Marketing” kategóriában feladott hirdetéseket.

\section{Adatbázis bemutatása}

Az összegyüjtött álláshirdetések alapján különböző változócsoportok kerültek meghatározásra, melyek az elemzés alapjául szolgáltak. Az egyes változók tulajdonságait az alábbi táblázat foglalja össze:

\begin{tabular}{|l|l|l|}
\hline Változócsoport & Változók & Előállítás módja \\
\hline $\begin{array}{l}\text { Álláshirdetés alapvető } \\
\text { jellemzői }\end{array}$ & - Álláshirdetés típusa & Kutatói meghatározás \\
& $-\quad \begin{array}{l}\text { Elvárt képzettség foka } \\
\text { és típusa }\end{array}$ & \\
& $\mid 2$ & \\
\hline
\end{tabular}




\begin{tabular}{|c|c|c|}
\hline Változócsoport & Változók & Előállítás módja \\
\hline & $\begin{array}{l}\text { - Hirdetés feladásának } \\
\text { az éve }\end{array}$ & \\
\hline $\begin{array}{l}\text { Álláshirdetést közzé } \\
\text { tevő cég alapvető } \\
\text { jellemzői }\end{array}$ & $\begin{array}{ll}\text { - } & \text { Szektor } \\
\text { - } & \text { Vevőkör } \\
\text { - } & \text { Tulajdonosi háttér } \\
\text { - } & \text { Lokáció }\end{array}$ & Kutatói meghatározás \\
\hline Tudás & $\begin{array}{ll}\text { - } & \text { Webes eszközök } \\
& \text { ismerete } \\
\text { - } & \text { Marketinges ismeretek } \\
\text { - } & \text { Grafikai alkalmazások } \\
& \text { ismerete } \\
\text { - } & \text { Programozás, mélyebb } \\
& \text { informatikai ismeretek } \\
\text { - } & \text { Keresőmarketing } \\
& \text { (SEO) ismeretek }\end{array}$ & Algoritmikus \\
\hline
\end{tabular}

Táblázat 37: Az adatbázisból származtatott változók

Forrás: saját szerkesztés

A kutatói meghatározással előállított változók az álláshirdetések elolvasása és értelmezése alapján kerültek meghatározásra, míg az algoritmikus változat esetében különböző kulcsszavak megléte, illetve hiánya volt a kategorizáció alapja (a kulcsszavakat ld. a Mellékletek közt). A kutatói meghatározásra épülő változók nagyobb rész csupán a közösségi médiához, online marketinghez kapcsolódó álláshirdetésekhez került megállapításra, ehhez kapcsolódtak ugyanis az elemzés központi kérdései.

\subsection{Elemzés}

\section{Teljes minta bemutatása}

A teljes adatbázis összesen $n=2.416$ megfigyelést tartalmazott, az egyes években pedig az alábbi bontás szerint alakultak a számok: 


\begin{tabular}{|c|c|c|c|c|c|}
\hline & & Gyakoriság & $\%$ & Érvényes \% & Kumulált \% \\
\hline$\overline{\text { Valid }}$ & 2010 & 275 & 11.4 & 11.4 & 11.4 \\
\hline & 2011 & 208 & 8.6 & 8.6 & 20.0 \\
\hline & 2012 & 120 & 5.0 & 5.0 & 25.0 \\
\hline & 2013 & 191 & 7.9 & 7.9 & 32.9 \\
\hline & 2014 & 210 & 8.7 & 8.7 & 41.6 \\
\hline & 2015 & 374 & 15.5 & 15.5 & 57.0 \\
\hline & 2016 & 316 & 13.1 & 13.1 & 70.1 \\
\hline & 2017 & 345 & 14.3 & 14.3 & 84.4 \\
\hline & 2018 & 377 & 15.6 & 15.6 & 100.0 \\
\hline & Összesen & 2416 & 100.0 & 100.0 & \\
\hline
\end{tabular}

\section{Táblázat 38: Álláshirdetések számának évenkénti megoszlása}

Forrás: saját szerkesztés

A táblázat adataiból is kiolvasható a gazdasági válság hatása: 2010-ről 2012-re kevesebb, mint felére esett vissza a marketing kategóriában feladott álláshirdetések száma, de hasonlóan kimutatható a 2013 utáni helyreállás (lassú) folyamata is, amit talán a legjobban az jellemez, hogy az összes álláshirdetés 41.6 százalékát az első öt, 58.4 százalékát az utolsó négy a vizsgálatba bevont évben adták föl.

Minden megfigyelés az álláshirdetések típusa szerint elöbb 7, majd aggregált formában 3 kategóriába került besorolásra, ez alapján az álláshirdetéseket az alábbi kategóriákban vizsgáltam: (1) Online marketing „közeli” terület; (2) Közösségi média marketing „,közeli” terület; (3) Egyéb marketing terület. A kutatás egyik első megállapítása az, hogy a közösségi média marketinggel kapcsolatos álláshirdetések száma (b) és aránya (j) is folyamatos bővülést mutatott a vizsgált időszakon belül (hasonló tendencia figyelhető meg - igaz kisebb volumenben - az online marketing „közeli” álláshirdetések terén is): 


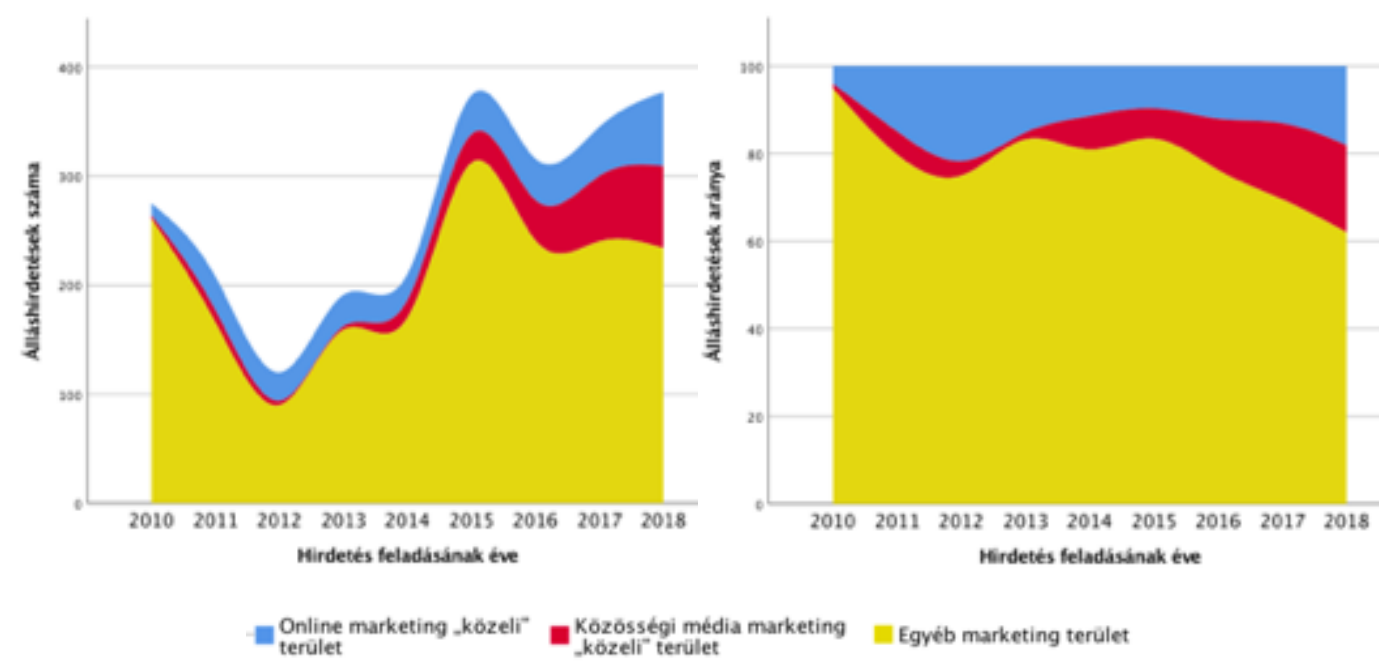

Ábra 27: Álláshirdetések száma és típusainak változása

Forrás: saját szerkesztés

A fenti ábra ugyanakkor az is jelzi, a magyar marketinges szakmában jelenleg található pozíciók nagyjából kétharmada nem igényel sem online sem közösségi média marketing tudást, ismereteket - a 2018-ban meghirdetett álláslehetőségek körében online marketinghez kapcsolódó pozíció 18.0 \%-ot, közösségi média marketinghez kapcsolódó pozíció 19.9 \%-ot, míg minden egyéb hirdetés 62.1 \%-ot tett ki.

A teljes adatbázis kiértékelése indokolatlan energiaráfordítást követelt volna meg a vizsgált téma szempontjából, ezért a részletes elemzések az első két kategóriára, az online marketing „közeli” valamint a közösségi média marketing „közeli” területekre készültek $(\mathrm{n}=558)$. A fennmaradt adatok révén ugyanakkor értékes bepillantást nyerhetünk egy eddig ritkán vizsgált területbe, a magyarországi marketing osztályok szervezeti folyamataiba, politikájába, így ennek elemzésére és értékelésére egy későbbi tanulmány keretében sor fog kerülni.

\section{Vizsgált minta bemutatása}

A szükebb mintát különböző változók szerinti (nem idősoros) bemutatását az alábbi táblázat foglalja össze gyakoriság és megoszlás szerint: 


\begin{tabular}{|c|c|c|c|c|c|}
\hline Álláshirdetés típusa & $\mathbf{n}$ & $\%$. & Munkvállalás helyszíne & $\mathbf{n}$ & $\%$ \\
\hline Online marketinges & 119 & 21.3 & (régió) & & \\
\hline Közösségi média marketinges & 33 & 5.9 & Budapest & 450 & 80.6 \\
\hline Egyéb marketing online & & & Kelet-Magyarország & 29 & 5.2 \\
\hline marketing területekkel, & 189 & 33.9 & Nyugat-Magyarország & 58 & 10.4 \\
\hline felelősséggel & & & (hiányzó) & 99 & 21 \\
\hline Egyéb marketing közösségi & & & Összesen & 558 & 100.0 \\
\hline $\begin{array}{l}\text { media marketıng teruletekkel, } \\
\text { felelősséggel }\end{array}$ & 134 & 24.0 & Hirdető cég vevőköre & $\mathbf{n}$ & $\%$ \\
\hline IT munkakör, marketing & 15 & 2.7 & $\mathrm{~B} 2 \mathrm{~B}$ & 219 & 39.2 \\
\hline feladatokkal & & & $\mathrm{B} 2 \mathrm{C}$ & 235 & 42.1 \\
\hline $\begin{array}{l}\text { Unime es Kozossegi meaia } \\
\text { marketinges }\end{array}$ & 44 & 7.9 & B2B és B2C & 61 & 10.9 \\
\hline Egyéb marketing, online és & & & Egyéb & 1 & .2 \\
\hline közösségi média területekkel, & 24 & 4.3 & (hiányzó) & 42 & 7.5 \\
\hline & & & Összesen & 558 & 100.0 \\
\hline Összesen & 558 & $\begin{array}{l}100 . \\
0\end{array}$ & $\begin{array}{l}\text { Hirdetô cég tulajdonosi } \\
\text { háttere }\end{array}$ & $\mathbf{n}$ & $\%$ \\
\hline Meghirdetett pozíció szintje & $\mathbf{n}$ & $\%$ & $\begin{array}{l}\text { nattere } \\
\text { Magyar nagyvállalat }\end{array}$ & 19 & 3.4 \\
\hline Gyakornok, asszisztens & 88 & 15.8 & Viagyar Hagy vallatat & & \\
\hline Munkatárs & 354 & 63.4 & Magyar KKV & 189 & 33.9 \\
\hline Menedzser & 98 & 17.6 & Külföldi tulajdonú & 300 & 53.8 \\
\hline Executive & 17 & 3.0 & $\begin{array}{l}\text { Egyéb } \\
\text { (hiányzó) }\end{array}$ & $\begin{array}{l}29 \\
21\end{array}$ & $\begin{array}{l}5.2 \\
3.8\end{array}$ \\
\hline (hiányzó) & 1 & .2 & Összesen & 558 & 100.0 \\
\hline Összesen & 558 & $\begin{array}{l}100 . \\
0\end{array}$ & Hirdető cég szektor & $\mathbf{n}$ & $\%$ \\
\hline Elvárt gyakorlat & $\mathbf{n}$ & $\%$ & Termelő & 113 & 20.3 \\
\hline Gyakorlat nélkül & 80 & 14.3 & Szolgáltató & 214 & 38.4 \\
\hline 1 év gyakorlat & 124 & 22.2 & Kereskedő & 131 & 23.5 \\
\hline 2-4 év gyakorlat & 248 & 44.4 & Ügynökség & 56 & 10.0 \\
\hline 5 év gyakorlat & 30 & 5.4 & Tanácsadó & 20 & 3.6 \\
\hline (hiányzó) & 76 & 13.6 & (hiányzó) & 24 & 4.3 \\
\hline Összesen & 558 & $\begin{array}{l}100 . \\
0\end{array}$ & Összesen & 558 & 100.0 \\
\hline Hirdetés feladásának éve & $\mathbf{n}$ & $\%$ & & & \\
\hline 2010 & 14 & 2.5 & & & \\
\hline 2011 & 43 & 7.7 & & & \\
\hline 2012 & 30 & 5.4 & & & \\
\hline 2013 & 38 & 6.8 & & & \\
\hline 2014 & 43 & 7.7 & & & \\
\hline 2015 & 65 & 11.6 & & & \\
\hline 2016 & 76 & 13.6 & & & \\
\hline 2017 & 105 & 18.8 & & & \\
\hline 2018 & 144 & 25.8 & & & \\
\hline Összesen & 558 & $\begin{array}{l}100 . \\
0\end{array}$ & & & \\
\hline
\end{tabular}


$\mathrm{Az}$ adatok egyszerü leíró statisztikáinak áttekintésével már több érdekes megállapítás is tehetö, igaz, az adatok helyes értelmezéséhez mindenképpen kiemelendő, hogy ezek nem az összes marketinges álláshirdetés alapján, hanem a probléma szempontjából fontos almintából, azaz az online- és közösségi média marketingre fókuszáló adatsor számaiból levont következtetések.

A vizsgálatba így bevont mintán a marketinggel kapcsolatos álláslehetőségek döntő többsége Budapestre koncentrálódott $(80.6 \%)$, a főváros dominanciája még jelentősebb lett volna, amennyiben az agglomeráció településeivel közös kategóriába került volna (pl. közép-magyarországi régió). A fennmaradó álláshelyeken 1:2 arányban osztozott Kelet- illetve Nyugat-Magyarország, ami az ország keleti régiójának gazdasági fejletlenségével magyarázható. A hirdető vállalatok tulajdonosi háttere alapján a hirdetések több, mint felét adták fel külföldi cégek (53.8\%), a magyar KKV szektor 33.9 százalék, míg magyar nagyvállalatok csupán 3.4\% erejéig képviseltették magukat az adatbázisban.

\section{Idősoros elemzés}

Az adatok idősoros vizsgálatának módszertani korlátját jelentette az, hogy bár 9 évet felölelve nagy elemszámú minta állt rendelkezésre, az időpontok csupán az évekkel jellemezhetőek, így a vizsgálat 9 időpont köré csoportosul - ez számottevő korlátokat jelentett a használható statisztikai módszerek körében. Az adatbázisban szereplő változók jelentős része nominális és/vagy dichotóm változó, csupán egyetlen valódi metrikus változó szerepelt (munkavállalóktól elvárt gyakorlati évek száma) - ám ez is olyan tulajdonságokat mutatott, hogy kategorizált, sorrendi változóként jobban használhatónak bizonyult.

Elsőként az online marketing valamint a közösségi média marketing területen meghirdetett álláshirdetések arányát érdemes megvizsgálni. Az elemzés előtt a marketinges álláshirdetések három önálló területre lettek felosztva, ezek az önálló kategóriák, valamint metszeteik képezték az elemzési egységeket, az alábbiak szerint: 


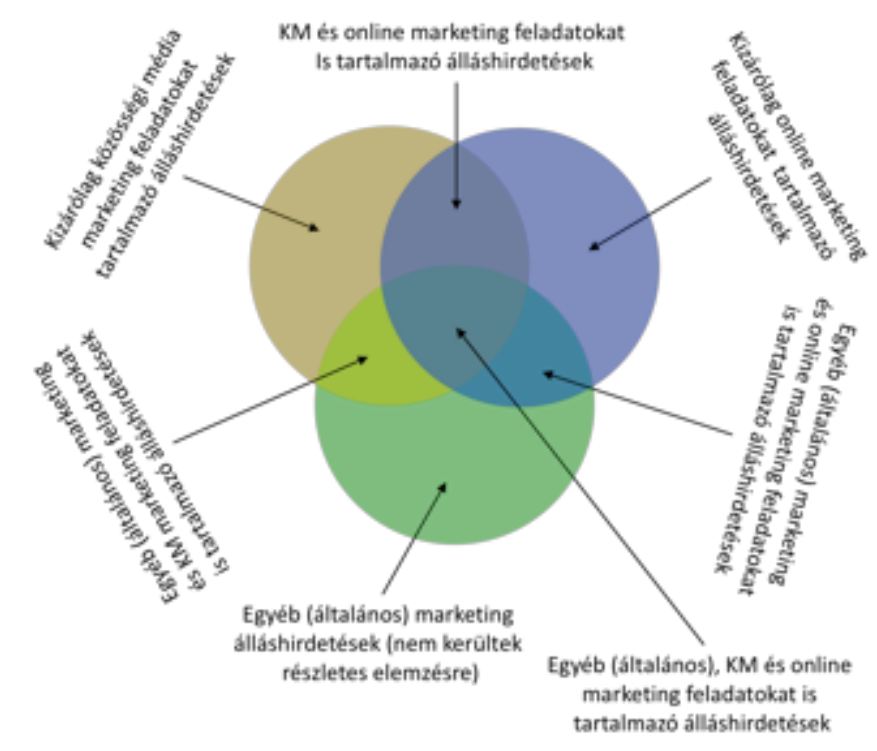

Ábra 28: Álláshirdetés típusok kialakításának szemléltető ábrája Forrás: saját szerkesztés

Az egyes kategóriákban feladott álláshirdetések száma az alábbi módon alakult a különböző években:

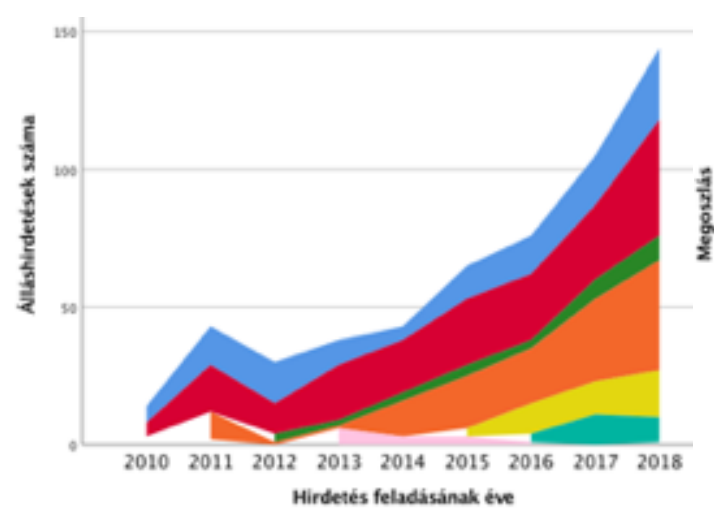

Hirdetés feladissának ève

Online marketinges Egyéb marketing online marketing ter felelósséggel

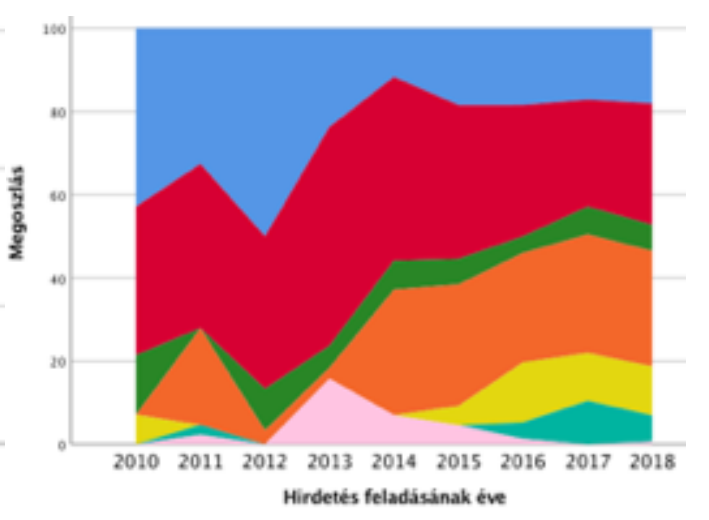

Online és közoosségi média Egyéb marketing közósségi marketinges
media marketing területekkel, Egyéb marketing, online és Egyéb marketing közósségi marketinges
media marketing területekkel, Egyéb marketing, online és kozósségi média területekkel

IT munkakör, marketing felelósseggel

\section{Ábra 29: Az egyes álláshirdetés kategóriákban feladott hirdetések száma és aránya}

Forrás: saját szerkesztés

$\mathrm{Az}$ álláshirdetések évenkénti száma a vizsgált részmintán hasonló alakot mutat, mint a korábban bemutatott, teljes mintában. A válság éveiben stagnálás, visszaesés a jellemző, míg 2015-től meredek emelkedés tapasztalható a közösségi média 
marketing és online marketing területen meghirdetett álláshirdetések számában. Érdekesség, hogy 2013-ban egy, már korábban is meglevő jelenség hirtelen erőteljesen megjelenik: marketing feladatokkal bővített informatikus álláshirdetések az abban az időpontban mért álláshirdetések közel 20 százalékát tették ki. Ez magyarázható azzal, hogy a cégek ilyen módon igyekeztek a válság közepette költségeiket csökkenteni. A jelenség ugyanakkor még egy évet tartott, és 2016 után gyakorlatilag már nem volt megfigyelhető - ennek egy lehetséges magyarázata az, hogy a cégek felismerték, hogy ez a feladatkörök ilyen fajta összevonása nem eredményes, hatékony.

A korábbi ábrán látható volt, hogy közösségi média marketing típusú álláshirdetések száma valamint aránya is gyakorlatilag folyamatosan bővült a vizsgált időszakban. A fenti ábrán már az is látható, hogy ez a bővülés három összetevő komponenseként áll elő:

- a kizárólag közösségi média marketing feladatokat tartalmazó álláshirdetések száma az időszakban nagyjából azonos arányt képvisel az adott éveken belül (0-14,3\% között mozgott aránya az egyes éveken belül), a kategória bővülése tehát elsősorban nem ennek az alkategóriának köszönhető

- az egyéb (,általános”) marketing feladatokat is és közösségi média marketing feladatokat is tartalmazó álláshirdetések száma 2013 után jelentős bővülést mutat (2013-ban 1 db, 2018-ban 40 db ilyen hirdetés volt megfigyelhetö)

- Az online-, közösségi média-, valamint egyéb (,általános”) marketing feladatokat is tartalmazó álláshirdetések csupán a vizsgált időszak végén jelentek meg, akkor sem jelentős számban (3-11 db/év)

\section{Válság hatása?}

Az adatok elemzése során több olyan szempont is felmerült, melyek alapján kijelenthető, hogy a 2014 előtti valamint az azt követő időszak eltérő sajátosságokat mutat. Az egyes években rögzített álláshirdetések puszta darabszáma is ugrásszerü növekedést mutat a két időszakban, amit mutat, hogy 2010-14 között 5 év alatt 168, 155 
míg 2015-18 között 4 év alatt közel háromszor ennyi álláshirdetés (390) jelent meg, ami az első időszakban éves átlagban 33,6 a következőben pedig 97,5 db álláshirdetést jelent.

A jelenség látványosan kirajzolódik az adatokat koordináta rendszerbe helyezve:

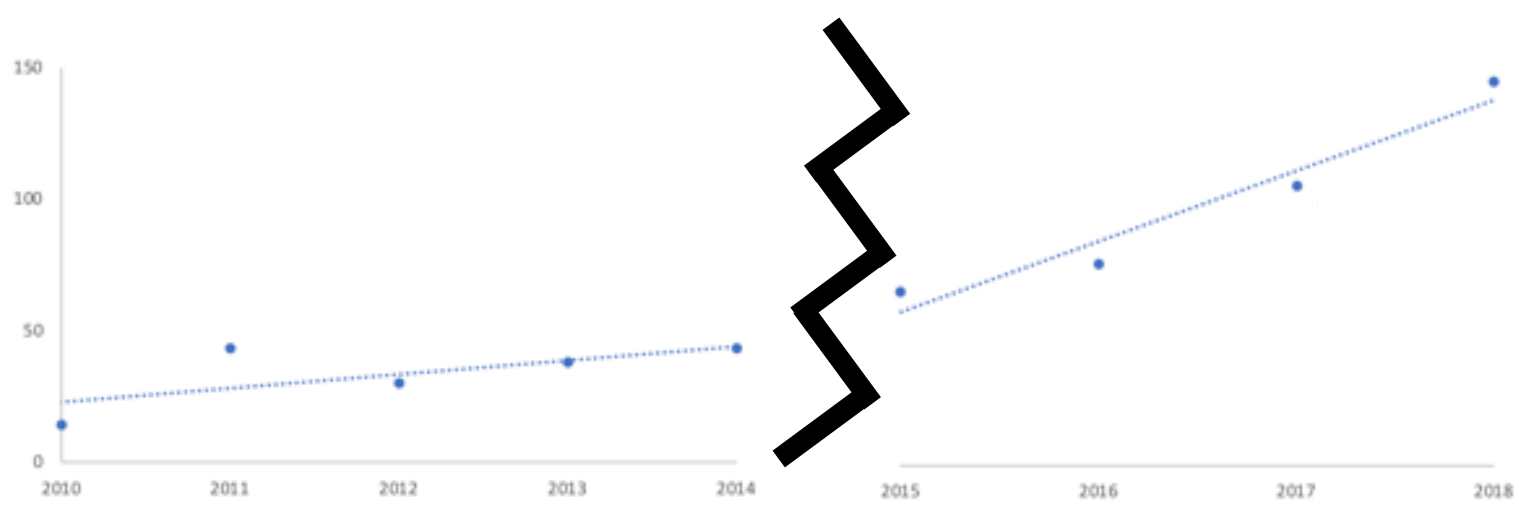

Ábra 30: Álláshirdetések számának alakulása a válság alatt és azt követően Forrás: saját szerkesztés

Hasonló törés volt tapasztalható az adatbázis egyéb változói esetében is:
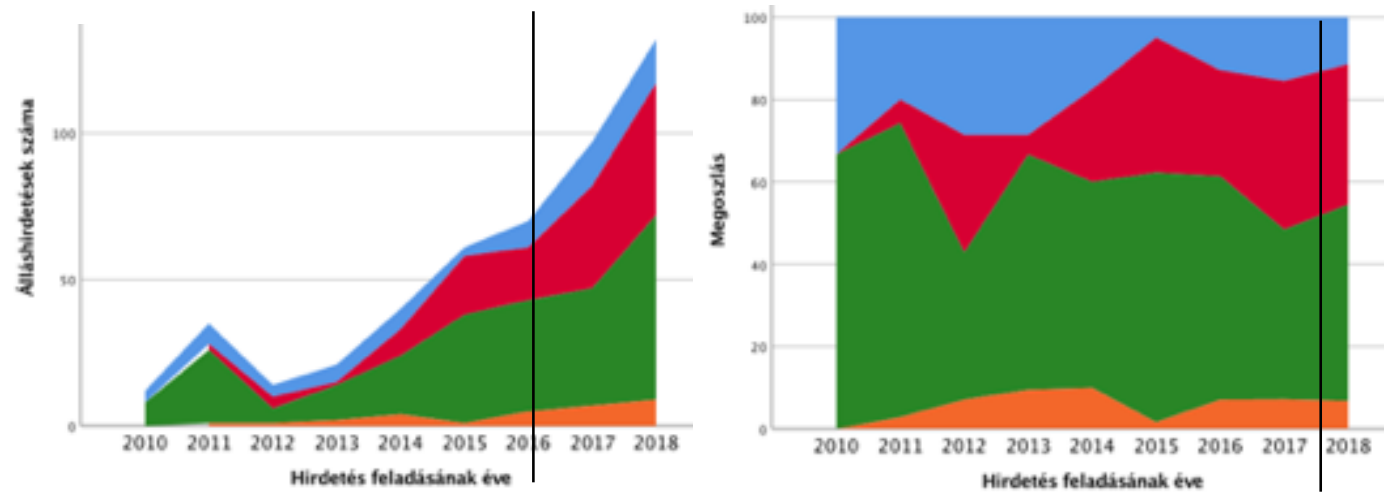

Eyakorlat nélkül

1 év gyakorlat

2-4 év gyakorlat 5 év gyakorlat

Ábra 31: Az eltérő gyakorlati szintet megkövetelő álláshirdetések számának és arányának az alakulása

Forrás: saját szerkesztés 


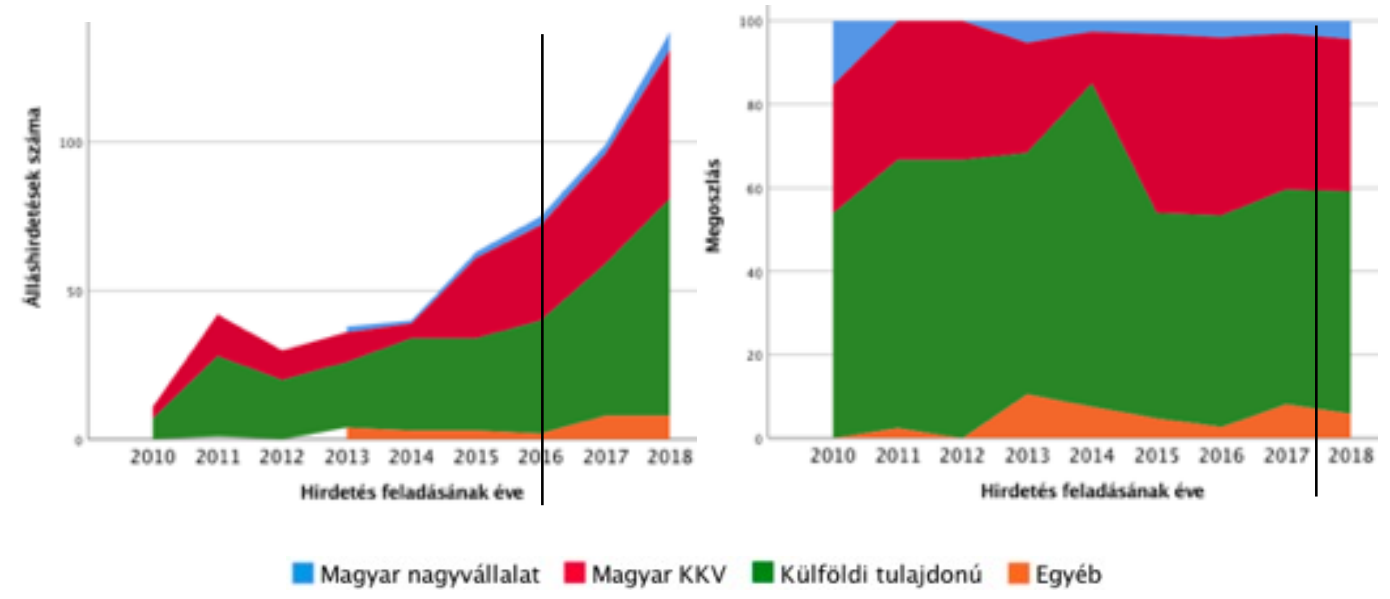

Ábra 32: Az eltérő tulajdonosi háttérrel feladott álláshirdetések számának és arányának az alakulása

Forrás: saját szerkesztés

Jól látható, hogy 2014-ig az elvárt gyakorlati tapasztalat nélkül meghirdetett álláshirdetések aránya az egyes éveken belül jóval magasabb volt, mint 2015-ben és utána. 2010-14 között az elvárt gyakorlati évek szempontjából bekategorizálható 122 álláshirdetés 23 százaléka esett ebbe a kategóriába, míg 2015-18 között ez az arány az ide tartozó 360 hirdetés esetében 13,6 százalék volt.

Ennek a jelenségnek két magyarázata is lehet: a tapasztalatlanabb, így olcsóbb munkaerő iránti kereslet a válsággal magyarázható. Ugyanakkor az is igaz, hogy az online marketing, és különösképpen a közösségi média marketing területe 2010 körül még gyerekcipőben járt, így nagyobb gyakorlattal rendelkező munkatársak egyébként is kevéssé voltak elérhetőek az időszak elején.

Az álláshirdetést közzé tevő cégek tulajdonosi hátterének összetételében is megfigyelhető olyan változás, ami a válsággal magyarázható: 2014 és azt megelőző években a hirdetések jelentősen kisebb hányadát tették közzé magyar tulajdonban levő cégek, míg 2015 után jóval kiegyenlítettebbé vált az arány: 


\begin{tabular}{|l|l|l|l|l|}
\hline \multicolumn{2}{|l|}{$2010-14$} & \multicolumn{2}{l|}{$2015-18$} \\
\hline $\begin{array}{l}\text { Magyar tulajdonú cégek } \\
\text { a teljes mintán belül }\end{array}$ & $48 \mathrm{db}$ & $29,5 \%$ & $160 \mathrm{db}$ & $42,7 \%$ \\
\hline $\begin{array}{l}\text { Külföldi tulajdonú cégek } \\
\text { a teljes mintán belül }\end{array}$ & $107 \mathrm{db}$ & $65,6 \%$ & $193 \mathrm{db}$ & $51,6 \%$ \\
\hline
\end{tabular}

Ábra 33: A magyar és külföldi tulajdonú cégek száma és aránya a teljes mintán belül

Forrás: saját szerkesztés

Ez teljesen összehangban van azzal, hogy a válság hatásai sokkal jobban sújtják a pénzügyileg kevésbé erős cégeket, mint a tőkeerős multinacionális cégeket. A mintán belüli arányok mellett az egyes kategóriák bővülését is érdemes megvizsgálni: a magyar hátterü cégek a második időszakban 333.33\%-kal több hirdetést adtak fel, a külföldi cégeknél ez a bővülés 180,37\%-os volt.

Az adatok alapján úgy tünik: ezek a változások 2008-ban kezdődött gazdasági válsággal, valamint annak lecsengésével vannak összefüggésben. Az álláshirdetések szerkezetének későbbiekben bemutatásra kerül belső, strukturális változása elsősorban a közösségi média- valamint az online marketing feladatok térnyerésével áll összefüggésben, míg a nyitott pozíciók számának radikális bővülése elsősorban a gazdasági környezet változásával magyarázható.

A kutatásban az idősoros adatok esetében, ahol erre szükség volt, a vizsgált 9 éves időtáv ezért két felé bontva is vizsgálatra került: a válság évei (2010-2014) és a válságot követő évek (2015-2018 között).

Közösségi média álláshirdetések elhatárolása a többi álláshirdetés közül

A korábbi, 28. ábrán látható módon az adatbázisban szereplő hirdetések 7-8 kisebb kategóriába sorolhatóak, de a vizsgált téma szempontjából fontos kérdések kutatásához a változószintek redukálásával ez két alapkategóriára egyszerüsíthető le:

- olyan álláshirdetések, amelyeknek van közösségi média vonatkozása 158 
- olyan álláshirdetések, amelyeknek nincs közösségi média vonatkozása

Ez tehát egy bináris változó [KAT2_A1], amelyhez kapcsolódó kérdésként az fogalmazódott meg, hogy milyen sajátosságokkal bíró álláshirdetések tartoznak egyik illetve másik csoportba. A kategóriába való tartozás feltételeit döntési fa módszertannal vizsgáltam. Ez a módszertan alapvetően egy döntéstámogató módszer, amelynek lényege, hogy bonyolult összefüggéseket egyszerü döntések sorozataként mutat be (Bodon, 2010). Habár döntési kritériumok meghatározásához szokás használni (pl. hitelbírálat, kockázati besorolás, stb), nem példa nélküli az sem, hogy bizonyos csoportokhoz való tartozás valószínüségének megállapítására használják (erre a legismertebb példa a terrorista-gyanús egyének besorolása). Ez utóbbi esetben a fa leveleiröl az alapsokaság viszonylag homogén alcsoportjai olvashatóak le. Marketing problémák vizsgálatában ritkán használt módszertan, ugyanakkor üzleti alkalmazás területen is használják adatok szegmentálására (pl. Dudás, 2018). Az álláshirdetéseket tartalmazó adatbázis sajátosságai miatt (pl. sok nominális és bináris változó) alkalmas módszertannak tünt és bizonyult a fenti kérdés vizsgálatára.

A döntési fa módszertan egyik előnye, hogy a lényegtelen változókat automatikusan felismeri és figyelmen kívül hagyja, amennyiben egy változóból nem nyerhető ki plusz információ magyarázott változóról, akkor annak tesztelésére nem is kerül sor (Bodon, 2010). Ez azt jelenti, hogy a módszer „zajos” környezetben is használható, és a problémamegértést is segíti az, hogy a fából leolvashatók a fontos változók. Népszerüségét indokolja még, hogy a függő valamint a magyarázó változó között kapcsolatot vizuális formában, könnyen leolvasható gráfként ábrázolja, ami a kapott eredmények interpretálását nagyban segíti (Dudás, 2018).

A kérdés vizsgálatához először a teljes minta vizsgálatára került sor, majd a válság éveibe tartozó alminta és a válságot követő évek almintáján ismét lefuttatásra került a vizsgálat, ami három döntési fát eredményezett. A vizsgálat során a függő változóként az álláshirdetések típusait két kategóriába sürítő KAT2_A1 változó lett használva, míg magyarázó változókként minden más változó bekerült a modellbe. 
A döntési fa generálását CHAID (Chi-squared Automatic Interaction Detection) algoritmussal végeztem, amihez a szükséges feltétel (viszonylagosan nagy mintaelemszám) adott volt. A megállítási kritériumok az SPSS programcsomag által kínált automatikus beállítások lettek, vagyis az egyesítés és felosztás küszöbszintjei $\alpha=.05$ szinten maradt, módosult ugyanakkor a felosztásra kerülö részadatbázisok minimális esetszáma (100 helyett 50), valamint a felosztás során keletkező új részadatbázisok minimális esetszáma (50 helyett 30).

A fenti paraméterek mellett a teljes $(n=558)$ minta alapján megrajzolt modellt az alábbi ábra tartalmazza:

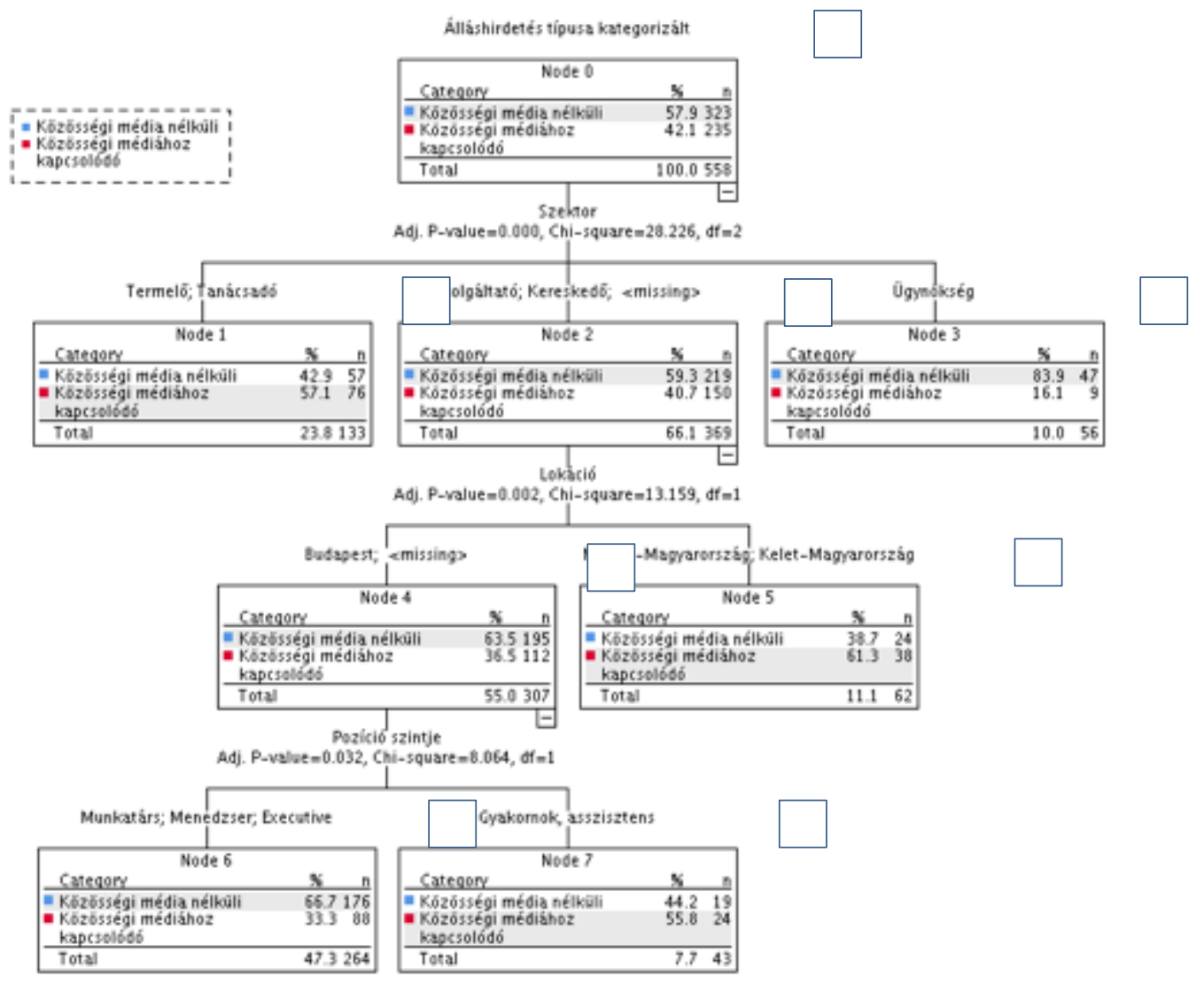

\section{Ábra 34: Döntési fa a teljes mintára}

Forrás: saját szerkesztés 
A döntési fa módszertan lényege, hogy a „gyökérhez” legközelebb eső változó a legerősebb magyarázó erővel bír, ez jelen esetben az álláshirdetést közzé tevő vállalat szektora, az alábbiak szerint:

- Az ügynökségek esetén kiemelkedően magas az olyan álláshirdetések aránya, melyek a közösségi médiához semmilyen módon nem kapcsolódnak

- A szolgáltató, valamint kereskedő vállalatok esetében nagyjából a teljes minta átlagához hasonló megoszlást tapasztalni

- A termelő és tanácsadó cégek az átlagosnál jelentősen több közösségi média hirdetés tesznek közzé

A fa a szolgáltató és kereskedő szektorban tevékenykedő cégek álláshirdetéseit tovább bontotta (ez a kategória volt a legnépesebb, az összes cég 66,13\%-a tartozott ebbe):

- A fővárosi székhelyü szolgáltató és kereskedő cégeknél a közösségi médiához nem kapcsolódó hirdetések voltak többségben

- A nyugat- és kelet-magyarországi cégeknél az arány fordított, de megjegyzendő: hiába volt relatív többségben a kategórián belül a közösségi médiához kapcsolódó hirdetések száma, a teljes kategória alacsony volumene miatt Budapesten az abszolút számot tekintve még így is közel háromszor annyi közösségi médiás álláshely került meghirdetésre szolgáltató és kereskedő cégeknél, mint vidéken.

Végül a budapesti székhelyü, szolgáltató, kereskedő cégeknél a meghirdetett pozíciók szintje is releváns döntési kritériumnak bizonyult:

- A magasabb szinteken (munkatárs, menedzser, executive) jellemzően nem szerepelt a feladatkörök leírásában közösségi médiával összefüggő feladat

- A legalacsonyabb (asszisztens vagy gyakornok) pozíciókban fordított volt az arány.

Összefoglalva a teljes mintára vonatkozó döntési fa az alábbi módon ábrázolható táblázatos módon: 


\begin{tabular}{|c|c|c|c|c|c|c|}
\hline \multirow[t]{2}{*}{$\#$} & \multicolumn{2}{|c|}{$\begin{array}{l}\text { Közösségi } \\
\text { kapcsolódó }\end{array}$} & \multicolumn{2}{|c|}{$\begin{array}{l}\text { Közösségi média } \\
\text { nélküli }\end{array}$} & \multirow[t]{2}{*}{ Becsült érték } & \multirow[t]{2}{*}{ Sig } \\
\hline & Eset & $\%$ & Eset & $\%$ & & \\
\hline 1 & 235 & 42,1 & 323 & 57,9 & KM nélküli & \\
\hline 2 & 76 & 57,1 & 57 & 42,9 & $\begin{array}{l}\text { KM } \\
\text { kapcsolódó }\end{array}$ & .000 \\
\hline 3 & 150 & 40,7 & 219 & 59,3 & KM nélküli & .000 \\
\hline 4 & 9 & 16,1 & 47 & 83,9 & KM nélküli & .000 \\
\hline 5 & 112 & 36.4 & 195 & 63.5 & KM nélküli & .002 \\
\hline 6 & 38 & 61.3 & 24 & 38.7 & $\begin{array}{l}\text { KM } \\
\text { kapcsolódó }\end{array}$ & .002 \\
\hline 7 & 88 & 33.3 & 176 & 66.7 & KM nélküli & .032 \\
\hline 8 & 24 & 55.8 & 19 & 44.2 & $\begin{array}{l}\text { KM } \\
\text { kapcsolódó }\end{array}$ & .032 \\
\hline
\end{tabular}

Táblázat 39: Döntési fa összefoglaló táblázata

Forrás: saját szerkesztés

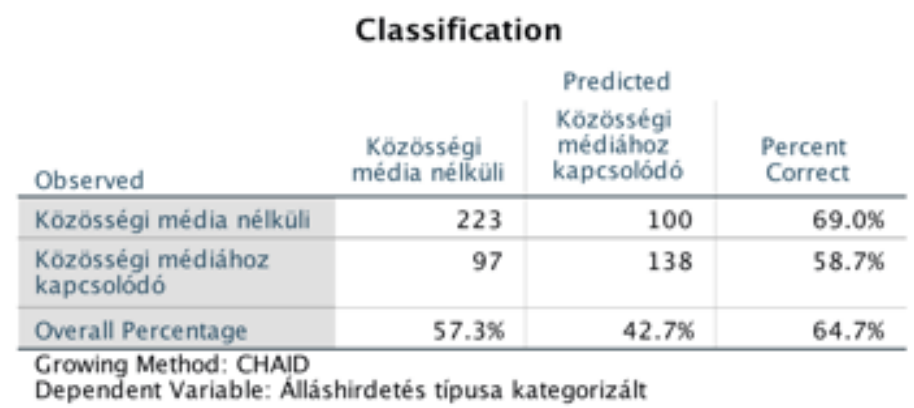

Táblázat 40: A teljes mintára vonatkozó döntési fa ellenőrzése

Forrás: saját szerkesztés

A modell ellenőrzését mutatja a 40. táblázat, melyből leolvasható, hogy a modellben hányszor volt tévedés és hányszor egyezés. A föátlóra eső megfigyelések aránya közepesen magas, a találati pontosság $64,7 \%$, ami elfogadhatónak nevezhető.

A vizsgálat következő részében a mintát kettévágva azt a kérdést boncolgattam, hogy az megfigyelt időszak első (2010-14) illetve második (2015-18) felében 
milyen különbözőségek fedezhetők fel. (A döntési fa futtatásának paraméterei mindenben megegyeztek a korábban ismertetettekkel).

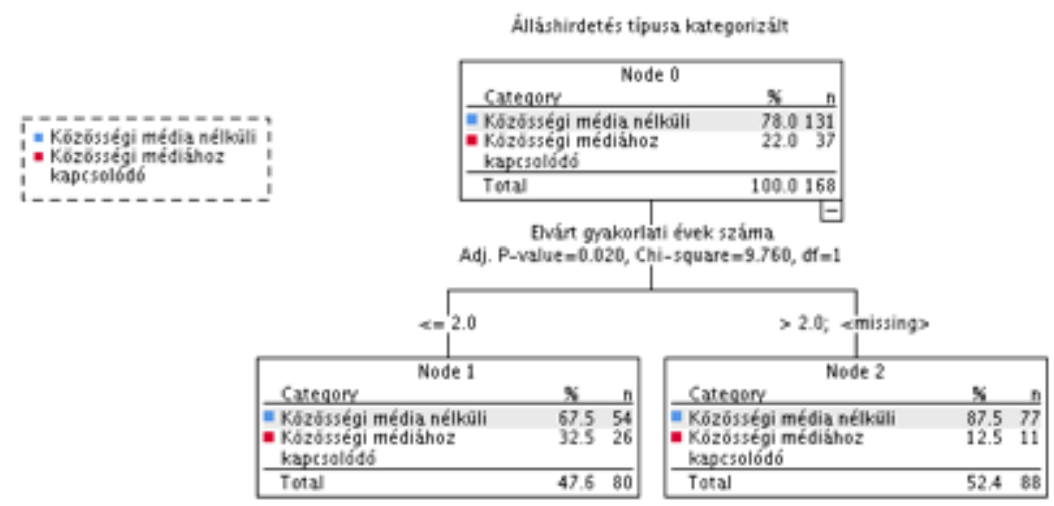

\section{Ábra 35: Döntési fa a válság éveire vonatkozó almintára \\ Forrás: saját szerkesztés}

A válság éveire lefuttatott elemzés jóval laposabb döntési fát eredményezett, aminek lehet módszertani magyarázata (a kisebb elemszám $(n=168)$ miatt jóval kevesebb változó szerint van lehetőség „megugrani” a minimális esetszámok szükséges számát). De elképzelhető az is, hogy a tapasztalt jelenség nem csak a válsággal, de azzal is összefüggésben áll, hogy maga a közösségi média marketing egésze ekkor még jóval rövidebb múltra tekinthet vissza, ennek megfelelően kisebb változatosság, a más álláshirdetésekhez való nagyobb hasonlóság jellemezi.

Különbséget egyetlen változó a gyakorlati évek száma alapján lehet tenni:

- Az elvárásként 2 vagy kevesebb év gyakorlatot támasztó pozíciók között arányaiban magasabb volt a közösségi médiához kapcsolódó álláshirdetések száma, mint a teljes almintában

- A 2-nél több év gyakorlatot elváró pozíciók körében viszont alig volt közösségi médiához kapcsolódó álláslehetőség

Ha végig gondoljuk, ez aligha meglepő. Ez az alminta időben 2010-től indul - a magyar cégek a közösségi médiával ekkor még nem/alig foglalkoztak, és a következő években kezd terjedni a közösségi média marketing idehaza. 163 


\begin{tabular}{|c|c|c|c|}
\hline \multicolumn{4}{|c|}{ Classification } \\
\hline & \multicolumn{3}{|c|}{ Predicted } \\
\hline Observed & $\begin{array}{l}\text { Közoosségi } \\
\text { média nélkuli }\end{array}$ & $\begin{array}{l}\text { Közósségi } \\
\text { médiához } \\
\text { kapesolódó }\end{array}$ & $\begin{array}{l}\text { Percent } \\
\text { Correct }\end{array}$ \\
\hline Kōzōsségi média nélküli & 131 & 0 & $100.0 \%$ \\
\hline $\begin{array}{l}\text { Kōzōsségi médiához } \\
\text { kapcsolódó }\end{array}$ & 37 & 0 & $0.0 \%$ \\
\hline Overall Percentage & $100.0 \%$ & $0.0 \%$ & $78.0 \%$ \\
\hline
\end{tabular}

Táblázat 41: A válság évei almintára vonatkozó döntési fa ellenőrzése Forrás: saját szerkesztés

A modell ellenőrzését mutatja a 41. táblázat, melyből kiderül, hogy az algoritmus minden esetet közösségi média nélküli álláshirdetésnek kategorizált. A főátlóra eső megfigyelések aránya viszonylag magas, a találati pontosság 78,0\%, ami jónak nevezhetö.

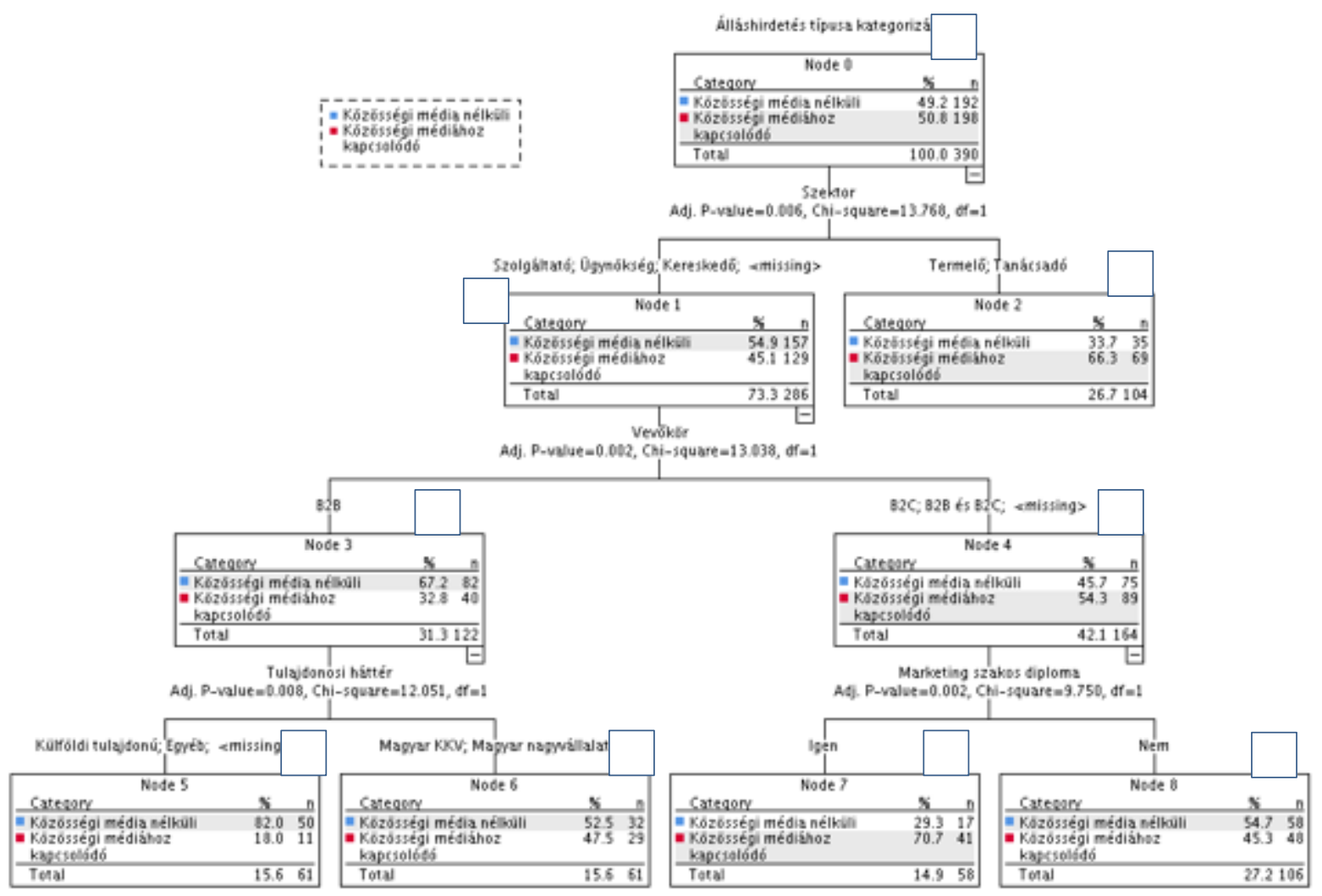

Táblázat 42: Döntési fa a válságot követő évek almintára

Forrás: saját szerkesztés 
A válságot követő időszakot vizsgálva az első fontos megállapítás, hogy az előző időszakban tapasztaltakkal szöges ellentétben a közösségi média marketinghez kapcsolódó álláshirdetések száma immár valamivel meg is haladta azok számát, melyek ahhoz semmilyen módon nem kapcsolódnak (50.8\% - 49.2\%). Ez egy újabb mutatója annak, milyen dinamikus bövülés volt megfigyelhető ezen a területen.

A teljes mintához hasonlóan itt is az álláshirdetést feladó cégek tevékenysége szerinti szektort mutatta az algoritmus a legfontosabb szelekciós kritériumnak.

- A termelö és tanácsadó cégeknél 1:2 arányban több közösségi média marketinges álláshirdetés volt megfigyelhetö, mint olyan, ami nem kapcsolódik a területhez. A teljes mintában szintén ebben a két szektorban volt többségben a közösségi média álláshirdetések aránya, de azok „fölénye” tovább növekedett

- A szolgáltató, kereskedő cégek, valamint az ügynökségek esetében ugyan a teljes mintához hasonlóan ebben az időszakban is a közösségi média feladatköröket nélkülöző álláshirdetések voltak túlsúlyban, azok arányok azonba lényegesen kiegyenlítettebbekké váltak.

A szolgáltató, kereskedő cégek, valamint az ügynökségi szektort tartalmazó levelet a döntési fa tovább bontotta (magas elemszám, $n=286$ ). A bontás két ága:

- B2B szektorban tevékenykedő cégek esetén alig mutatkozott igény olyan munkavállalók iránt, akik közösségi média területén is jártassággal bírnak (ez megerősíti a szakértői mélyinterjúknál tapasztaltakat). A B2B szektoron belül a külföldi tulajdonú cégeknél a közösségi média marketinges álláshirdetések aránya még alacsonyabb volt (az egyéb kategória elemszáma ( $n=1)$ elhanyagolható); míg a magyar vállalatok esetén már közelebb állt a teljes minta megoszlásához.

- A B2C valamint vegyes (B2B és B2C) profilú cégeknél a közösségi médiához kapcsolódó hirdetések aránya magasabb, mint az ahhoz nem kapcsolódók száma. Ezt a levelet a döntési fa módszer a marketing szakos diploma megléte alapján bontotta még tovább: azoknál a hirdetéseknél, ahol követelményként jelent meg a marketing szakirányos diploma megléte, 
jóval magasabb volt a közösségi média feladatköröket tartalmazó hirdetések száma.

Összefoglalva a válságot követő évek almintára vonatkozó döntési fa az alábbi módon foglalható össze táblázatos módon:

\begin{tabular}{|c|c|c|c|c|c|c|}
\hline \multirow[t]{2}{*}{ \# } & \multicolumn{2}{|c|}{$\begin{array}{l}\text { Közösségi médiához } \\
\text { kapcsolódó }\end{array}$} & \multicolumn{2}{|c|}{$\begin{array}{l}\text { Közösségi média } \\
\text { nélküli }\end{array}$} & \multirow[t]{2}{*}{ Becsült érték } & \multirow[t]{2}{*}{ Sig } \\
\hline & Eset & $\%$ & Eset & $\%$ & & \\
\hline 1 & 198 & 50,8 & 192 & 49,2 & KM kapcsolódó & \\
\hline 2 & 129 & 45,1 & 167 & 54,9 & KM nélküli & .006 \\
\hline 3 & 69 & 66,3 & 35 & 33,7 & KM kapcsolódó & .006 \\
\hline 4 & 40 & 32,8 & 82 & 67,2 & KM nélküli & .002 \\
\hline 5 & 89 & 54,3 & 75 & 46,7 & KM kapcsolódó & .002 \\
\hline 6 & 11 & 18,0 & 50 & 82,0 & KM nélküli & .008 \\
\hline 7 & 32 & 53,5 & 29 & 47,5 & KM kapcsolódó & .008 \\
\hline 8 & 41 & 70,7 & 17 & 29,3 & KM kapcsolódó & .002 \\
\hline 9 & 48 & 45,3 & 58 & 54,7 & KM nélküli & .002 \\
\hline
\end{tabular}

Táblázat 43: Döntési fa táblázatos összefoglalása

Forrás: saját szerkesztés

\begin{tabular}{|c|c|c|c|}
\hline \multicolumn{4}{|c|}{ Classification } \\
\hline & & Predicted & \\
\hline Observed & $\begin{array}{l}\text { Közösségi } \\
\text { média nélküli }\end{array}$ & $\begin{array}{l}\text { Közōsségi } \\
\text { médiához } \\
\text { kapcsolódó }\end{array}$ & $\begin{array}{l}\text { Percent } \\
\text { Correct }\end{array}$ \\
\hline Kōzösségi média nélküli & 140 & 52 & $72.9 \%$ \\
\hline $\begin{array}{l}\text { Kōzösségi médiához } \\
\text { kapcsolódó }\end{array}$ & 88 & 110 & $55.6 \%$ \\
\hline Overall Percentage & $58.5 \%$ & $41.5 \%$ & $64.1 \%$ \\
\hline
\end{tabular}

Táblázat 44:A válságot követő évek almintára vonatkozó döntési fa ellenőrzése Forrás: saját szerkesztés

A modell ellenőrzését mutatja a 44. táblázat, melyböl leolvasható, hogy a modellben hányszor volt tévedés és hányszor egyezés. A föátlóra eső 
megfigyelések aránya közepesen magas, a találati pontosság 64,1\%, ami elfogadhatónak nevezhető.

\section{Álláshirdetések szegmentálása klaszterelemzéssel}

$\mathrm{Az}$ álláshirdetéseket klaszterelemzéssel szegmentáltam, az eredmények felhasználásával a közösségi média és nem közösségi média típusú álláshirdetések egy új szempontból, az igényelt képességek, valamint az oktatási háttér szempontjából vizsgáltam meg. A klaszterváltozók előállítása a K-közép módszerrel történt.

A klaszterelemzésbe csak dichotóm változók kerültek be, melyek az egyes álláshirdetésekben az adott pozíció betöltéséhez szükséges különböző tudás/képességek valamint a szükséges végzettség álláshirdetésben való meglétét/hiányát jelezték, így a kiugró értékek vizsgálatára nem volt szükség. Az ugyanakkor ismert, hogy nem hierarchikus módszer egyik hátránya (tulajdonsága), hogy klaszterszámokat előzetesen rögzíteni szükséges. Az elemzés megkezdése előtt több különböző variációban, eltérő módszertanok felhasználásával (hierarchikus klaszter, két lépéses (two-steps) klaszter) vizsgáltam az adatbázist. Az előzetes vizsgálatok alapján úgy tünt, hogy 3 klaszter rajzolódik ki az adatokból, így a K-közép módszertan ezzel a inputtal került lefuttatásra.

A következő táblázatok összefoglalják, hogy az egyes klaszterek milyen módon térnek el a sokaság átlagától az alábbi jellemzők tekintetében:

- A klaszterhez tartozó álláshirdetések betöltéséhez feltételként támasztott végzettség foka illetve iránya

- A megkövetelt ismertek és tudások, melyeket összefoglalóan öt csoportba soroltam:

○ grafikai ismeretek

○ programozási ismeretek

○ általánosabb marketing ismeretek

○ online marketing ismeretek

○ keresőmarketing ismeretek 
A táblázatban a kék szín az adott ismérv szerinti legalacsonyabb értéket, a piros a legmagasabbat jelölte 


\begin{tabular}{|c|c|c|c|c|c|c|c|c|c|c|c|}
\hline \multicolumn{2}{|l|}{ Végzettség } & \multirow{2}{*}{ 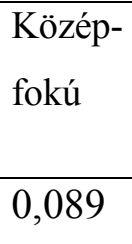 } & \multirow{2}{*}{$\begin{array}{l}\text { Felsőfokú } \\
0,218\end{array}$} & \multirow{2}{*}{$\begin{array}{l}\text { Marketing } \\
\text { diploma } \\
0,409\end{array}$} & \multirow{2}{*}{$\begin{array}{l}\text { Gazdasági } \\
\text { diploma } \\
0,020\end{array}$} & \multirow{2}{*}{ 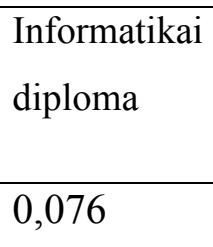 } & \multirow{2}{*}{$\begin{array}{l}\text { Mérnök } \\
\text { diploma }\end{array}$} & \multirow{2}{*}{$\begin{array}{l}\text { Bölcsész } \\
\text { diploma } \\
0,013\end{array}$} & \multirow{2}{*}{$\begin{array}{l}\text { HR sz. } \\
\text { diploma } \\
0,013\end{array}$} & \multirow{2}{*}{$\begin{array}{l}\text { Kvantitatív } \\
\text { sz. diploma }\end{array}$} & \multirow{2}{*}{$\begin{array}{l}\text { Művész } \\
\text { diploma }\end{array}$} \\
\hline Klaszterközép & Klaszter 1 & & & & & & & & & & \\
\hline Klaszterközép & Klaszter 2 & 0,045 & 0,080 & 0,273 & 0,034 & 0,159 & 0,045 & 0,011 & 0,000 & 0,034 & 0,125 \\
\hline Klaszterközép & Klaszter 3 & 0,078 & 0,240 & 0,246 & 0,102 & 0,084 & 0,018 & 0,024 & 0,006 & 0,048 & 0,006 \\
\hline Minta átlag & & 0,08 & 0,20 & 0,34 & 0,05 & 0,09 & 0,02 & 0,02 & 0,01 & 0,03 & 0,03 \\
\hline $\begin{array}{l}\text { Eltérés a } \\
\text { mintaátlagtól }\end{array}$ & Klaszter 1 & $1,0 \%$ & $1,5 \%$ & $7,0 \%$ & $-2,7 \%$ & $-1,5 \%$ & $-0,9 \%$ & $-0,3 \%$ & $0,4 \%$ & $-1,2 \%$ & $-1,7 \%$ \\
\hline $\begin{array}{l}\text { Eltérés a } \\
\text { mintaátlagtól }\end{array}$ & Klaszter 2 & $-3,4 \%$ & $-12,3 \%$ & $-6,6 \%$ & $-1,3 \%$ & $6,8 \%$ & $2,9 \%$ & $-0,5 \%$ & $-0,9 \%$ & $0,5 \%$ & $9,8 \%$ \\
\hline $\begin{array}{l}\text { Eltérés a } \\
\text { mintaátlagtól }\end{array}$ & Klaszter 3 & $-0,1 \%$ & $3,7 \%$ & $-9,3 \%$ & $5,5 \%$ & $-0,7 \%$ & $0,2 \%$ & $0,8 \%$ & $-0,3 \%$ & $1,9 \%$ & $-2,1 \%$ \\
\hline
\end{tabular}




\begin{tabular}{|c|c|c|c|c|c|c|c|c|c|}
\hline \multicolumn{2}{|c|}{ Grafikai ismeretek } & \multirow{2}{*}{$\begin{array}{l}\text { Adobe termékek } \\
0,000\end{array}$} & \multirow{2}{*}{$\begin{array}{l}\text { Flash } \\
0,003\end{array}$} & \multirow{2}{*}{$\begin{array}{l}\text { Indesign } \\
0,000\end{array}$} & \multirow{2}{*}{$\begin{array}{l}\text { Dreamweaver } \\
0,000\end{array}$} & \multirow{2}{*}{$\begin{array}{l}\text { Photoshop } \\
0,000\end{array}$} & \multirow{2}{*}{$\begin{array}{l}\text { Final Cut } \\
0,000\end{array}$} & \multirow{2}{*}{$\begin{array}{l}\text { Premiere } \\
\text { Pro } \\
0,000\end{array}$} & \multirow{2}{*}{$\begin{array}{l}\text { Corel } \\
0,000\end{array}$} \\
\hline Klaszterközép & Klaszter 1 & & & & & & & & \\
\hline Klaszterközép & Klaszter 2 & 0,568 & 0,080 & 0,284 & 0,080 & 0,670 & 0,011 & 0,011 & 0,068 \\
\hline Klaszterközép & Klaszter 3 & 0,030 & 0,006 & 0,000 & 0,000 & 0,084 & 0,000 & 0,000 & 0,000 \\
\hline Minta átlag & & 0,1 & 0,02 & 0,05 & 0,01 & 0,13 & 0,00 & 0,00 & 0,01 \\
\hline $\begin{array}{l}\text { Eltérés a } \\
\text { mintaátlagtól }\end{array}$ & Klaszter 1 & $-9,9 \%$ & $-1,3 \%$ & $-4,5 \%$ & $-1,3 \%$ & $-13,1 \%$ & $-0,2 \%$ & $-0,2 \%$ & $-1,1 \%$ \\
\hline $\begin{array}{l}\text { Eltérés a } \\
\text { mintaátlagtól }\end{array}$ & Klaszter 2 & $46,9 \%$ & $6,4 \%$ & $23,9 \%$ & $6,7 \%$ & $53,9 \%$ & $0,9 \%$ & $0,9 \%$ & $5,7 \%$ \\
\hline $\begin{array}{l}\text { Eltérés a } \\
\text { mintaátlagtól }\end{array}$ & Klaszter 3 & $-6,9 \%$ & $-1,0 \%$ & $-4,5 \%$ & $-1,3 \%$ & $-4,7 \%$ & $-0,2 \%$ & $-0,2 \%$ & $-1,1 \%$ \\
\hline
\end{tabular}




\begin{tabular}{|c|c|c|c|c|c|c|c|c|c|}
\hline \multirow{3}{*}{\begin{tabular}{|l|} 
\\
Klaszterközép \\
\end{tabular}} & & \multicolumn{6}{|c|}{ Programozással kapcsolatos ismeretek } & \multicolumn{2}{|c|}{ Általános marketing ismeretek } \\
\hline & & UX & HTML & XML & CSS & PHP & SQL & Copywriting & Szövegírás \\
\hline & Klaszter 1 & 0,010 & 0,000 & 0,000 & 0,003 & 0,000 & 0,000 & 0,000 & 0,000 \\
\hline Klaszterközép & Klaszter 2 & 0,023 & 0,500 & 0,057 & 0,364 & 0,102 & 0,080 & 0,057 & 0,068 \\
\hline Klaszterközép & Klaszter 3 & 0,060 & 0,186 & 0,000 & 0,108 & 0,048 & 0,048 & 0,036 & 0,186 \\
\hline \multicolumn{2}{|l|}{ Minta átlag } & & 0,13 & 0,01 & 0,09 & 0,03 & 0,03 & 0,02 & 0,07 \\
\hline $\begin{array}{l}\text { Eltérés } \\
\text { mintaátlagtól }\end{array}$ & Klaszter 2 & $-1,7 \%$ & $-13,4 \%$ & $-0,9 \%$ & $-8,8 \%$ & $-3,0 \%$ & $-2,7 \%$ & $-2,0 \%$ & $-6,6 \%$ \\
\hline $\begin{array}{l}\text { Eltérés a } \\
\text { mintaátlagtól }\end{array}$ & Klaszter 2 & $-0,4 \%$ & $36,6 \%$ & $4,8 \%$ & $27,3 \%$ & $7,2 \%$ & $5,3 \%$ & $3,7 \%$ & $0,2 \%$ \\
\hline $\begin{array}{l}\text { Eltérés a } \\
\text { mintaátlagtól }\end{array}$ & Klaszter 3 & $3,3 \%$ & $5,2 \%$ & $-0,9 \%$ & $1,7 \%$ & $1,8 \%$ & $2,1 \%$ & $1,6 \%$ & $12,0 \%$ \\
\hline
\end{tabular}




\begin{tabular}{|c|c|c|c|c|c|c|c|c|}
\hline & & \multicolumn{4}{|c|}{ Webes marketing ismeretek } & \multicolumn{3}{|c|}{ Keresőmarketing ismeretek } \\
\hline & & Adserver & Joomla & Wordpress & Drupal & $\mathrm{PPC}$ & Adwords & SEO \\
\hline Klaszterközép & Klaszter 1 & 0,003 & 0,000 & 0,017 & 0,000 & 0,000 & 0,000 & 0,000 \\
\hline Klaszterközép & Klaszter 2 & 0,023 & 0,023 & 0,102 & 0,000 & 0,080 & 0,193 & 0,034 \\
\hline Klaszterközép & Klaszter 3 & 0,000 & 0,012 & 0,120 & 0,024 & 0,353 & 0,599 & 0,443 \\
\hline Minta átlag & & 0,01 & 0,01 & 0,06 & 0,01 & 0,12 & 0,21 & 0,14 \\
\hline $\begin{array}{l}\text { Eltérés a } \\
\text { mintaátlagtól }\end{array}$ & Klaszter 2 & $-0,2 \%$ & $-0,7 \%$ & $-4,4 \%$ & $-0,7 \%$ & $-11,8 \%$ & $-21,0 \%$ & $-13,8 \%$ \\
\hline $\begin{array}{ll}\text { Eltérés } & \text { a } \\
\text { mintaátlagtól }\end{array}$ & Klaszter 2 & $1,8 \%$ & $1,6 \%$ & $4,1 \%$ & $-0,7 \%$ & $-3,8 \%$ & $-1,7 \%$ & $-10,4 \%$ \\
\hline $\begin{array}{l}\text { Eltérés a } \\
\text { mintaátlagtól }\end{array}$ & Klaszter 3 & $-0,5 \%$ & $0,5 \%$ & $5,9 \%$ & $1,7 \%$ & $23,5 \%$ & $38,9 \%$ & $30,5 \%$ \\
\hline
\end{tabular}

\section{Táblázat 45: Klaszterek jellemzése}

Forrás: saját szerkesztés 
A klaszterek jellemzéséhez az egyes ismérvek tekintetében a három klaszter együttesen vizsgálva kirajzolódott, hogy az egyes klaszterek milyen módon jellemezhetők:

\begin{tabular}{|c|c|c|c|}
\hline \multirow{2}{*}{ Klaszter } & \multirow{2}{*}{ Diploma } & \multicolumn{2}{|l|}{ Tudás } \\
\hline & & Jellemzően elvárt & Jellemzően nem elvárt \\
\hline $\begin{array}{l}1 \\
\text { „Marke- } \\
\text { tinges” } \\
\text { állás- } \\
\text { hirdetés }\end{array}$ & $\begin{array}{l}\text { Marketing } \\
\text { szakos } \\
\text { diploma } \\
\text { (kisebb } \\
\text { részben } \\
\text { középfokú } \\
\text { végzettség) }\end{array}$ & $\begin{array}{l}\text { Egyetlen } \quad \text { tudás } \\
\text { jellemző esetében sem } \\
\text { mutatható } \mathrm{ki \quad} \quad \mathrm{az} \\
\text { átlagtól magasabb } \\
\text { érték }\end{array}$ & $\begin{array}{l}\text { Szinte valamennyi vizsgált } \\
\text { tudás ismérv tekintetéven } \\
\text { átlag alatti értékek } \\
\text { figyelhetők meg. Kiugróan } \\
\text { alacsony érték nincs, } 10 \\
\text { százalékpont körüli eltérés } \\
\text { figyelhető meg az alábbiak } \\
\text { esetén: } \\
\text { - Grafikai csoporton } \\
\text { belül: } \\
\text { termékek, Adobe } \\
\text { Photoshop } \\
\text { Programozás } \\
\text { csoporton belül: } \\
\text { HTML, CSS } \\
\text { Szövegírás } \\
\text { Valamennyi } \\
\text { keresőmarketinggel } \\
\text { kapcsolatos tudás }\end{array}$ \\
\hline $\begin{array}{l}2 \\
\text { „Informa- } \\
\text { tikus” } \\
\text { állás- } \\
\text { hirdetés }\end{array}$ & $\begin{array}{l}\text { Informatikai, } \\
\text { mérnök } \\
\text { diploma } \\
\text { (művész } \\
\text { diploma nem } \\
\text { releváns, } \\
\text { mivel a teljes } \\
\text { sokaságban }\end{array}$ & $\begin{array}{l}\text { Több vizsgált } \\
\text { kategóriában is } \\
\text { található kiugró } \\
\text { (átlaghoz mért } 20 \\
\text { százalékpontnál } \\
\text { magasabb eltérést } \\
\text { mutató) érték: }\end{array}$ & $\begin{array}{l}\text { Egyetlen kategóriában volt } \\
\text { megfigyelhető jelentős } \\
\text { negatív eltérés a } \\
\text { mintaátlaghoz képest: a } \\
\text { keresőmarketinggel } \\
\text { kapcsolatos tudás esetén: } \\
\text { - SEO, Adwords, } \\
\text { PPC }\end{array}$ \\
\hline
\end{tabular}




\begin{tabular}{|c|c|c|c|}
\hline \multirow{2}{*}{ Klaszter } & \multirow{2}{*}{ Diploma } & \multicolumn{2}{|l|}{ Tudás } \\
\hline & & Jellemzően elvárt & Jellemzően nem elvárt \\
\hline & $\begin{array}{l}\text { mindösszesen } \\
15 \\
\text { megfigyelést } \\
\text { érintett) }\end{array}$ & 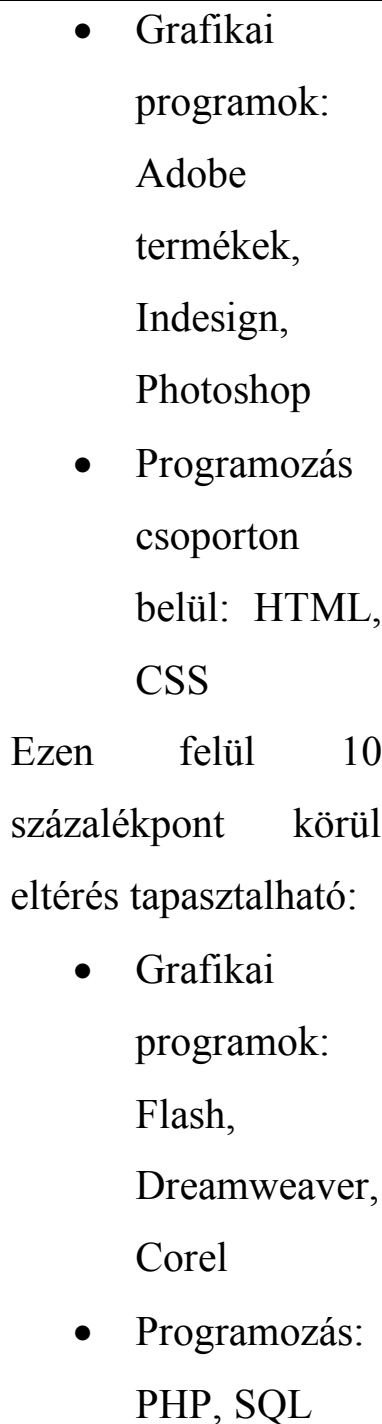 & \\
\hline $\begin{array}{l}3 \\
\text { „SEO } \\
\text { szakérto”” } \\
\text { állás- } \\
\text { hirdetés }\end{array}$ & $\begin{array}{l}\text { Általános } \\
\text { felsőfokú } \\
\text { végzettség } \\
\text { (diploma/ } \\
\text { gazdasági } \\
\text { diploma }\end{array}$ & $\begin{array}{l}\text { A klaszter kiugró } \\
\text { értékei } \\
\text { keresőmarketinggel } \\
\text { kapcsolatos } \\
\text { tudáskategóriák: } \\
\text { - Szövegírás } \\
\text { - SEO, } \\
\text { Adwords, PPC }\end{array}$ & $\begin{array}{l}\text { Egyetlen tudás jellemzö } \\
\text { esetében sem mutatható ki } \\
\text { az átlagtól jelentősen } \\
\text { alacsonyabb érték }\end{array}$ \\
\hline
\end{tabular}

Táblázat 46: A három klaszter összefoglalása

Forrás: saját szerkesztés 
A klaszterbesorolások egy különös eredménye az első klaszter jellemzése. Az adatok azt mutatják, hogy azok az álláshirdetések, ahol marketinges diplomát vártak el, az átlagosnál kisebb arányban támasztották követelményként a vizsgált tudáskategóriák meglétét. Ez elsőre meglepőnek tünhet, amire azonban magyarázatul szolgálhat az, hogy a kifejezetten marketinges végzettségü munkavállalókat az online illetve közösségi média munkakörökben más módokon alkalmaznak. Ezt erősíti, hogy a kifejezetten informatikai ismereteket megkövetelő álláshirdetéseket a második klaszterben találni, ahol pedig a müszaki-informatikai végzettség a domináns. Illetve arra is érdemes ráirányítani a figyelmet, hogy kifejezetten marketing tudást (pl. márkázás, értékesítési készségek, stb) jelen tanulmányban nem vizsgáltam.

Az előállt klasztereket több más változóval összevetve vizsgáltam. Az első fontos megállapítás, hogy a klaszterek esetében a vizsgálat nem talált szignifikáns összefüggést az álláshirdetések feladásának évével, sem annak kategorizált (válság alatt / válság után) változójával. Ez azt mutatja, hogy klaszterek időben stabilak

Terjedelmi korlátok miatt a kereszttáblákat és azok megfelelöségi mutatóit a mellékletek közt közlöm, az alábbiakban összefoglalóan láthatók az elvégzett vizsgálatok eredményei (zárójelben a Pearson féle Khí-négyzet teszt szignifikancia szintje):

\begin{tabular}{|c|c|c|c|}
\hline & $\begin{array}{l}\text { „Marketinges" } \\
\text { álláshirdetések }\end{array}$ & $\begin{array}{l}\text { „Informatikus" } \\
\text { álláshirdetések }\end{array}$ & $\begin{array}{l}\text { „SEO szakérto"” } \\
\text { álláshirdetések }\end{array}$ \\
\hline $\begin{array}{l}\text { Pozíció szintje } \\
(.000)\end{array}$ & $\begin{array}{l}\text { Jellemzően } \\
\text { munkatárs, illetve } \\
\text { asszisztensi, } \\
\text { gyakornoki } \\
\text { pozíciók }\end{array}$ & $\begin{array}{l}\text { Jellemzően } \\
\text { munkatárs } \\
\text { pozíciók }\end{array}$ & $\begin{array}{l}\text { Jellemzően } \\
\text { munkatárs, illetve } \\
\text { menedzser } \\
\text { pozíciók }\end{array}$ \\
\hline $\begin{array}{l}\text { Hirdető cég } \\
\text { szektor } \\
(.001)\end{array}$ & $\begin{array}{l}\text { Jellemzően } \\
\text { termelő, } \\
\text { szolgáltató és } \\
\text { kereskedő cégek }\end{array}$ & $\begin{array}{l}\text { Jellemzően } \\
\text { szolgáltató és } \\
\text { kereskedő cégek }\end{array}$ & $\begin{array}{l}\text { Jellemzően } \\
\text { szolgáltató és } \\
\text { kisebb részben } \\
\text { kereskedő cégek }\end{array}$ \\
\hline
\end{tabular}




\begin{tabular}{|c|c|c|c|}
\hline & $\begin{array}{l}\text { „Marketinges" } \\
\text { álláshirdetések }\end{array}$ & $\begin{array}{l}\text { „Informatikus" } \\
\text { álláshirdetések }\end{array}$ & $\begin{array}{l}\text { „SEO szakérto”" } \\
\text { álláshirdetések }\end{array}$ \\
\hline $\begin{array}{l}\text { Vevőkör } \\
(.069)\end{array}$ & $\begin{array}{l}\text { B2C (50\%) és B2B } \\
(40 \%) \text { cégek }\end{array}$ & $\begin{array}{l}\text { B2C }(49,4 \%) \text { és } \\
\text { B2B }(38 \%) \text { cégek }\end{array}$ & 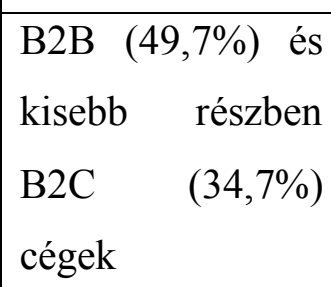 \\
\hline $\begin{array}{l}\text { Álláshirdetést } \\
\text { közzé tevő cég } \\
\text { tulajdonosi } \\
\text { háttere } \\
(.078)\end{array}$ & $\begin{array}{l}\text { A másik két } \\
\text { klaszterhez képest } \\
\text { kiemelkedően } \\
\text { magas a külföldi } \\
\text { tulajdonú hátterü } \\
\text { cégek aránya } \\
(57,0 \%)\end{array}$ & $\begin{array}{l}\text { Nem jellemzik } \\
\text { kiugró értékek }\end{array}$ & $\begin{array}{l}\text { A másik két } \\
\text { klaszterhez képes } \\
\text { kiemelkedően } \\
\text { magas a magyar } \\
\text { KKV hátterü } \\
\text { cégek aránya } \\
(39,9 \%)\end{array}$ \\
\hline $\begin{array}{l}\text { Megkövetelt } \\
\text { gyakorlati } \\
\text { tapasztalat } \\
\text { éveinek száma } \\
(.000)\end{array}$ & $\begin{array}{l}\text { A legjellemzőbb a } \\
2-4 \text { év közötti } \\
\text { elvárt } \\
\text { munkatapasztalat, } \\
\text { az egyetlen } \\
\text { kategória, ahol } \\
\text { viszonylag sok } \\
\text { munkatapasztalat } \\
\text { nélküli pozíció volt } \\
\text { nyitva }\end{array}$ & $\begin{array}{l}\text { 1-4 év közötti } \\
\text { tapasztalat az } \\
\text { általánosan elvárt, } \\
\text { 5-nél több évnyi } \\
\text { tapasztalat } \\
\text { egyetlen } \\
\text { álláshirdetésben } \\
\text { sem szerepelt } \\
\text { követelményként }\end{array}$ & $\begin{array}{l}\text { 2-4 év közötti } \\
\text { tapasztalat az } \\
\text { általánosan elvárt, } \\
1 \text { év tapasztalatot } \\
\text { ezen } \\
\text { álláshirdetések } \\
\text { kb. harmada várt } \\
\text { el. Többi }\end{array}$ \\
\hline
\end{tabular}

\section{Táblázat 47: A klaszterek összefüggése más változókkal}

Forrás: saját szerkesztés

A leginkább szembeötlö és a marketingszervezettel kapcsolatos megállapítás, hogy a „marketinges” klaszter álláshirdetései a szervezeti hierarchia alsóbb szintjeivel hozhatók kapcsolatba (asszisztens, munkatárs), míg az „informatikus” és a „SEO szakértő” klaszternél magasabb szintek is megtalálhatóak (munkatárs-menedzser). Ez értelmezhető úgy, hogy ezek az álláskörös a szervezeti hierarchia magasabb szintjein állnak, de úgy is, hogy a szervezeti hierarchia magasabb szintjein a marketinges munkakörök betöltőitől (marketing-)informatikai tudást 176 
megkövetelnek a cégek. Mivel az adatbázis kifejezetten online- és közösségi média marketinges álláshirdetéseket tartalmazott, úgy vélem, ez utóbbi lehetőség mellett több érv szól.

Két olyan szempont is volt (az álláshirdetést közzé tevő cég tulajdonosi hátterére, valamint vevőkörére vonatkozó változók), ahol a vizsgált változóval való kapcsolat csupán 10 százalékos szignifikancia szinten nevezhető szignifikánsnak.

\subsection{Következtetések}

\begin{tabular}{|c|c|}
\hline Szempont & Következtetések, fontosabb kutatási megállapítások \\
\hline Teljes minta & $\begin{array}{l}\text { Igazolódott a régi mondás (sejtés): nehéz gazdasági } \\
\text { körülmények (pl. válság) esetén a cégek a marketing } \\
\text { költségvetést nyirbáljak meg az első közt. A gazdasági válság } \\
\text { alatt évente átlagosan } 200,8 \text { álláshirdetést adtak fel, míg } \\
\text { 2015-öt követően az átlag évi 353-ra nőtt. (A teljes adatbázis } \\
\text { mélyebb elemzése egy következő tanulmány feladata lesz) }\end{array}$ \\
\hline $\begin{array}{l}\text { Online- és közösségi média } \\
\text { marketing álláshirdetésekböl } \\
\text { álló alminta leíró statisztikái }\end{array}$ & $\begin{array}{l}\text { - A gazdasági világválság fentebb jelzett hatása } \\
\text { kimutatható: a válság éveiben átlagosan } 33,6 ; 2015 \\
\text { után évi } 97,5 \text { álláshirdetést tettek közzé ebben a } \\
\text { kategóriában. A hatást az online- és közösségi média } \\
\text { marketing dinamikus bővülése is felerősítette. } \\
\text { - Az almintában az alacsonyabb pozícióba sorolható, } \\
\text { kevesebb gyakorlatot elváró pozíciók kerültek } \\
\text { - Területi megoszlás szerint a főváros túlsúlya } \\
\text { jellemző, az összes álláshirdetés } 80,6 \% \text { budapesti, a } \\
\text { maradékon } \\
1 / 3-2 / 3 \text { arányban osztozik Kelet- és Nyugat- } \\
\text { Magyarország }\end{array}$ \\
\hline
\end{tabular}




\begin{tabular}{|c|c|}
\hline Szempont & Következtetések, fontosabb kutatási megállapítások \\
\hline Idősoros elemzés & $\begin{array}{l}\text { A válság hatása nem csak az álláshirdetések számában érhető } \\
\text { tetten, de struktúrájában is kimutatható. A válság alatt } \\
\text { arányaiban több a gyakorlat nélkül betölthető pozíció. A } \\
\text { hirdetések feladói közt } 2015 \text { után radikálisan megnő a } \\
\text { magyar vállalatok/vállalkozások aránya valamint az általuk } \\
\text { feladott hirdetések darabszáma is. }\end{array}$ \\
\hline $\begin{array}{l}\text { Közösségi média és más } \\
\text { online hirdetések közötti } \\
\text { különbségtétel }\end{array}$ & $\begin{array}{l}\text { A vizsgálat az adatbázis egészére, valamint a kategorizált } \\
\text { évek (válság évei / válság utáni évek) szerinti változóra is le } \\
\text { lett futtatva: } \\
\text { - A teljes mintán a legfontosabb differenciáló változó } \\
\text { az álláshirdetést feladó cég tevékenységi szektora, } \\
\text { majd ezt tovább bontja a cég elhelyezkedése, valamint } \\
\text { a meghirdetett pozíció szintje } \\
\text { - A válság évei alatt feladott hirdetésekben különbséget } \\
\text { az elvárt gyakorlati évek száma alapján lehet tenni } \\
\text { - A } 2015 \text { és azt követően feladott hirdetések esetében } \\
\text { pedig szintén a szektor, valamint azon belül a } \\
\text { vevőkör, tulajdonosi háttér és diploma típusa alapján } \\
\text { lehet legjobban kettéválasztani a közösségi média } \\
\text { valamint más hirdetések közötti különbségeket }\end{array}$ \\
\hline
\end{tabular}




\begin{tabular}{|c|c|}
\hline Szempont & Következtetések, fontosabb kutatási megállapítások \\
\hline Klaszterelemzés & $\begin{array}{l}\text { A teljes adatbázist az álláshirdetésekben megkövetelt tudás } \\
\text { valamint az elvárt diploma alapján három klaszterre lehet } \\
\text { bontani: } \\
\text { - „Marketinges” álláshirdetések: marketing szakirányú } \\
\text { diploma, kevés online tudást igénylő pozíciók } \\
\text { - „Informatikus” álláshirdetések: kiemelkedően magas } \\
\text { mérnöki/informatikai diploma arány, kifejezetten } \\
\text { elvárja bizonyos informatikai tudás illetve készség } \\
\text { meglétét } \\
\text { „SEO szakértő” álláshirdetések: általánosabb } \\
\text { végzettség (pl. gazdasági diploma), kiugró értékek a } \\
\text { keresőmarketinggel kapcsolatos tudáskategóriák } \\
\text { A klaszterek a vizsgált időtávon stabilnak mutatkoztak, nem } \\
\text { sikerült szignifikáns eltérést kimutatni az évek során }\end{array}$ \\
\hline
\end{tabular}

Táblázat 48: A kutatás harmadik fázisának legfontosabb megállapításai

Forrás: saját szerkesztés 


\section{IV. Összegzés}

\section{Kutatási kérdések megválaszolása, következtetések}

\section{RQ1: Milyen adaptációs stratégiával válaszolnak a marketingszervezetek arra}

a környezeti kihívásra, amelyet közösségi média megjelenése, terjedése jelent?

Leeflang et al. (2014) megmutatta, hogy a vállalatokat a közösségi média marketing célú alkalmazása több területen is kihívások elé állítja - ezek között vannak könnyebben és nehezebben menedzselhető problémák, vannak, amelyekre kész forgatókönyvek állnak készen, és vannak olyanok, ahol ilyenek nem állnak rendelkezésre. Az első kutatási kérdés megválaszolására vonatkozó információk mind a mélyinterjúkban, mind a vállalati esettanulmányokban fellelhetők voltak. A marketingvezetőkkel készült mélyinterjúk alapján a közösségi média jelenleg három szinten épül be a vállalati gyakorlatba:

1. higiéniás-tényező („,csináljuk, mert ez az elvárás”)

2. cél-követő (egy-két jól körülhatárolható feladat -pl. vevőszolgálat- erejéig használják)

3. stratégiai szintü használat

A három közül az elmondások alapján az utolsó, legmagasabb szintü használat egyelőre nem jellemző - de többen is jelezték, hogy a közeli jövőben már elérheti ezt a szintet.

A marketing szakemberek által adott válaszokból kiderült: a turbulens környezetre a rugalmasabb szervezeti forma (külső tanácsadók, ügynökségek intenzív igénybevétele) az egyik jellemző válasz. A közösségi média marketing szervezeti beépítésére nincsenek kész sablonok, de a saját szervezet felduzzasztása mellett/helyett az ökoszisztéma szerü működés több válaszban is felbukkant lehetséges alternatívaként. Ezt indokolja a speciális tudásszükséglet, valamint az is, hogy ez a szervezetközi tudásmegosztás és tudásfelhalmozás hatékonyabb formája. 
Másik lehetséges út a szervezeti tanulás korábbiaknál intenzívebb ösztönzése, ami a tanuló szervezet kiépítése irányába mutató lépés lehet több vállalat esetén. Igaz ugyanakkor, hogy a vizsgálat keretét adó Argote (2012) szervezeti tanulást leíró modelljében egyelőre még nagyobb rések is tapasztalhatók a közösségi média marketing területén - különösen a szervezet és környezet relációjában.

\section{RQ2. Milyen típusú kihívásokkal kell megküzdeniük a marketingosztályoknak a közösségi média implementációjában a magyar piacon?}

A kutatás első fázisában megkérdezett marketing vezetők többen a szervezeti átalakítás „hogyan”-ját és „miként”-jét a legfontosabb kérdések közé sorolták, emellett szinte valamennyiben beszéltek saját félelmeikről, közösségi médiával kapcsolatos korábbi negatív tapasztalataikról (negatív viralitás, kontroll vesztés, tudásbeli hiányosságok, stb). Kiemelték még a terület újszerü mivoltát, vagyis azt, hogy a kihívások kezelésére sokszor nem állnak rendelkezésre készen használható forgatókönyvek, iparági „,best practise”.

A kihívások kezelésére különböző utakat vázoltak fel a kutatás első fázisában megkérdezett marketing vezetök. Különbség tehető a szerint, hogy mennyiben igyekeznek házon belül, saját alkalmazottak révén megoldani a tudásigény kielégítését. Vagy ehelyett az ökoszisztéma szerü müködésre támaszkodva külső partnerek (ügynökségek, tanácsadók) segítségét keresik - ami a folyamatok fölötti kontroll egy alacsonyabb szintjét jelenti. Habár a szakirodalmi áttekintés alapján feltételezett átalakulás nem volt kimutatható az ökoszisztémaszerü müködésre, ennek nyomai felfedezhetők voltak az álláshirdetéseket tartalmazó adatbázis vizsgálatában, ahol föként az időszak második felében már olyan piaci szereplőknél is bővült a munkaerő iránti kereslet, melyek feltételezhetően ilyen együttmüködések külső szereplői lehetnek (ügynökségek, tanácsadó cégek).

A marketingszervezet és vállalat kapcsolata is átalakul. A kutatás második fázisában vizsgált vállalati esetek feltárták, hogy: 
- a marketing feladatok szétáramlanak a szervezetben

- olyan szervezeti egységektől is érkeznek inputok a marketingosztály felé, ami korábban nem/kevéssé volt jellemző (pl. HR, IT,)

A magyar piac egyik specialitása a multi cégek meghatározó aránya, amit azt is jelenti, hogy a vállalati vezetőknek sokszor olyan helyzethez kell alkalmazkodniuk, ami szigorúan a magyar piaci körülmények közt vizsgálva szuboptimális (erre több vállalatnál is panaszkodtak). Ez érinti a közösségi média marketinget is, az Magyaroroszágon sokszor a külföldi központ direktívái alapján müködik, nem feltétlenül (nem kizárólag) a magyar piacról érkező inputok alapján.

Végül a közösségi média megközelíthető a diszruptív innováció talaján állva. Az online közeg és a közösségi média átalakítja a hagyományos marketingkommunikációs csatornákat (pl. marginalizálódó újsághirdetési piac, a niché piacok irányába elmozduló magazinok, stb), megváltoztathatja a cégek termékét (pl. katalógus), versenytársait (pl. médiapiac), a termék/szolgáltatás iránti piaci keresletet (pl. online újságok).

\section{RQ3. A közösségi média sikeres implementációjához a vállalatoknak milyen új marketing képességek megszerzésére van szükségük?}

Az újonnan megjelenő feladatok munkavállalók szempontjából két csoportra bonthatók:

- korábbi kompetenciákat igényel, de a korábban megszokotthoz képest más formában (nagyobb volumenben, a feladatokon belül a hangsúly máshova esik, stb). Erre példa lehet az ún. influencerekkel való kapcsolattartás, ami feladatként hasonlít a hírességek alkalmazására - miközben számos ponton el is tér attól

- teljesen új kompetenciákat igényel (pl. közösségi monitoring, social listening, big data elemzés, stb), melyeket a marketingszervezet napi müködésébe integrálni kell 
Az interjúkból ugyanakkor egyértelműen kiderült az is, és ezt az álláshirdetésekből álló adatbázis vizsgálata is alátámasztotta: nem csak minőségben más, de „darabszámra” is több munkavállalóra van szükségük a marketingosztályoknak a közösségi média korában. És azt is megmutatta a kutatás, hogy nem csak marketing, de egyéb képességek, készségek megszerzésére, valamint attitüdbeli (szervezeti kultúrabeli?) változásokra is szükség van: kommunikáció, kreatív kompetenciák, kvantitatív ismeretek, stb.

Habár nem tartozik szigorúan a képességek közé, ki kell emelni a szervezeti kultúra kérdéskörét is, ami mind a kutatás első, mind a második fázisában hangsúlyos szempontként jelent meg a vállalati szakemberek válaszaiban. A kutatás során kapott válaszok bizonyos szempontból ugyanabba az irányba mutattak: a gyakorló szakértők percepciója az, hogy a közösségi média egy nagyon jól körül írható, fiatalos, nyitott, optimista, befogadó kulturális közeg. Ahhoz, hogy ebben a közegben sikeresek lehessenek a cégek, a megkérdezettek közül többek véleménye szerint is hasonló szervezeti kultúra megteremtése alapfeltételként fogalmazódik meg.

A szervezet egésze mellett az átalakulás egy másik területe a vezetői képességek, készségek átalakulása. A kutatás gyakorlatilag mindhárom fázisában látni nyomát annak, hogy a cégek egyes esetekben akár készek „,megszabadulni” is azoktól a vezetőktől, akik az online és közösségi világot „nem értik”. A vezetőknek nem csak a készségek (analitikus, projektmenedzseri, adaptációs készség, stb) terén, de személyiségjegyeikben (nyitottság, gyors tanulásra való képesség), affinitásban (technológiai érzékenység) valamint tudásban és ismeretekben (eszközhasználat) is készen kell állniuk a változásra.

\section{RQ4. Hogyan alakította át a marketingszervezet tudás és kompetencia igényét a közösségi média implementációja?}

A kutatás során három olyan marketinggel összefüggésben levő vállalati területet tártam fel, ahol a közösségi média transzformáló hatása kimutatható: 
- Az operatív müködésben adatvezérelt fejlesztés új menedzsment megközelítést igényel. Az ügyfélszolgálatban új eszközök használata mellett a kommunikációs stílus megváltoztatására is szükség van. A hirdetések kezelését az ezernyi új formátum valamint a hirdetések intenzív utókövetése miatt megnövekedett idöbeli nyomás és annak menedzselése nehezíti. Végül az értékesítési feladatokban az ügyféllel történő kommunikációban csatornaként jelenik meg a közösségi média.

- Informatikában a felhasználói élmény (UX) tervezéséhez grafikus, programozói és webszerkesztési képességekre van szükség, de elengedhetetlen a fogyasztói magatartás elmélyült ismerete is. Az IT és marketing osztályok müködésének egy másik közös területe az új típusú fizetési módozatok integrálásának követelménye, amelyhez a szükséges programozói és informatikai szaktudás nélkülözhetetlen

- Marketingben a kampányok hatékonyság- és hatásosság elemzéséhez eszközismeret valamint elemzői készség szükségeltetik

\section{Következtetések és a kutatás további eredményei}

A kutatás első fázisában megkérdezett marketingvezetők, valamint az álláshirdetésekből álló adatbázis eredményei között egy látszólagos ellentmondás fedezhető fel. A vezetők közül többen is egyértelmüen hitet tettek a közösségi média marketing mellett (,ez a jövő”). Eközben az álláshirdetés adatbázis elemzése egyértelmüen kimutatta, hogy az ezzel kapcsolatos pozíciók a szervezet alacsonyabb szintjein (gyakornok, munkatárs) nyitottak. Erős kontraszt tapasztalható a közösségi médián kívüli online marketinggel való összevetésben is - az online marketinggel (SEO, internet, stb) kapcsolatos kompetenciák ugyanis már magasabb, menedzseri szinteken is elvárásként jelennek meg. Ez az ellentmondás ugyanakkor csupán látszólagos, és azt mutatja, hogy a szervezetek még keresik a közösségi média implementálásának leghatékonyabb módját, és utal arra is, hogy bár a jövőben stratégiai szintü szerepet szánnak a közösségi médiának, 
a jelen inkább még az erre történő felkészülés, tudásgyüjtés szakaszaként jellemezhető.

A szakértői interjúkból valamint a vállalati esetek feldolgozásából kiderült: nem csak költségbeli előnyöket keresnek a cégek, amikor a korábbi csatornák mellett illetve azok rovására a közösségi média irányába bővítik a marketing tevékenységüket. A használat „driver”-ei között olyan szempontokat találni még, mint a technológiai és használati előnyök (pl. jobb célzás, bizonyos célcsoport elérése, jobb mérési lehetőségek, stb), külföldi központok direktívái, stb. Egymás mellé téve az érem két (több) oldalát, tehát azt látjuk, hogy a cégek megítélése szerint a közösségi média a marketingkommunikáció egy olcsóbb lehetőségét jelenti, a többi csatornánál jobb feltételek, magasabb szintű szolgáltatások mellett. Ez a közösségi média használat drágulását vetíti előre (ennek 2018-ban már látni elöjeleit).

A kutatás nem szándékolt, de véleményem szerint fontos eredménye a gazdasági világválságnak a marketingre gyakorolt egy hatásának bemutatása volt, az álláshirdetések alakulásán keresztül. A meghirdetett pozícióknak nem csak a darabszáma, hanem azok struktúrája is átalakult, a válság intenzitással hatott a különböző iparágakban, az ország eltérő vidékein, valamint a magyar illetve külföldi tulajdonban álló cégek körében is. Hasonlóan nem szándékolt eredmény volt az ország három régiója (Budapest, Kelet-, illetve Nyugat-Magyarország) közötti óriási eltérések feltárása.

\section{További kutatási lehetőségek}

A disszertáció elméleti jelentőségét az adja, hogy egy szakirodalmi „vakfoltot” beazonosítva, több irányból megközelítve, különböző módszertanokkal vizsgálta meg a közösségi média marketing térnyerése okán megváltozott szervezeti viszonyokat, kifejezetten a magyar környezetben. A dolgozat áttekintette a legfontosabb kapcsolódó fogalmakat a közösségi média marketing, szervezetelmélet terén is. 
A mü egy másik erényének tekinthető, hogy a gyakorló szakemberek megkérdezése (kvalitatív szakasz) mellett olyan adatokra támaszkodott, amelyet a szakemberek személyes véleménye kevéssé torzíthatott (álláshirdetések). Egy olyan, a marketing „közéletben” divatosnak számító téma esetén, mint amilyen e disszertáció írásakor a közösségi média is, mindig fennáll annak a veszélye, hogy a megkérdezés során a szakemberek a várakozásaiknak, és nem a tényeknek megfelelő válaszokat fognak adni. A mélyinterjú során ennek a kezelésére szélesebb lehetőség nyílt, mint lett volna egy kérdőíves megkérdezés esetében.

A disszertációban (anonimizált formában) bemutatott vállalati esetek segíthetik a gyakorló szakembereket is a napi munkájuk végzésében. A kapott eredmények érvényességét erősíti, hogy több iparág, eltérő piaci- és versenyhelyzetben levő vállalatától érkező adatokra támaszkodva születtek meg.

A munka ugyanakkor a kutatás természete miatt komoly korlátokkal is szembesült. Az alkalmazott módszertanok korlátait a módszertani fejezetben már részletesen ismertettem. Más fontos korlátok voltak a kutatás környezetében is. Habár a közösségi média már bö 10 éve hétköznapjaink része, annak vállalati alkalmazása sok szempontból még ma is kiforratlan, a cégek ezzel kapcsolatos döntéseit kiforrott és kiérlelt döntési szabályok helyett - láttuk - sok alkalommal még heurisztikák jellemzik. Ezt a hatást a magyar gazdaság szerkezete is felerősíti - az itt működő cégek sok esetben nem (teljesen) önálló döntést hoznak, hanem más országokban található központok direktívái alapján müködnek. A kutatás első két fázisában (szakértői mélyinterjúk illetve vállalati esetek) nem lettek bevonva olyan cégek, melyek eleve online közegben jöttek létre, az ő álláspontjuk, ami valószínűsíthetően eltér a hagyományos iparágakban dolgozó vállalatoktól, így nem szerepel a dolgozatban.

A disszertáció írásakor több olyan lehetőség is felmerült, amellyel a kutatás folytatható lehet. Az álláshirdetés adatbázis elemzésére kifejezetten csak online és közösségi média marketing szempontból került sor. Ez azt is jelentette, hogy az adatok közül háromnegyedét a részletes vizsgálatból ki kellett zárni - miközben ez nagy potenciált jelenthet még a jövőre nézve. 
A szakirodalmi áttekintés során szempontként felmerült, hogy a közösségi média alkalmazások használata a 20-25 évvel ezelőtti (vagy valamivel még korábbi) ERP rendszerek bevezetésével is párhuzamba állítható: mindkét eset egy alapvetően informatikai rendszer vállalati alkalmazásáról szól, de már ott is jeleztem: számos különbség is megfigyelhető. Ennek a kérdésnek az alaposabb feltárása is egy újabb kutatás témája lehet. A jelenlegi kutatást érdemes lenne kiterjeszteni olyan cégek bevonásával is, akik online közegben „születtek” meg. Feltételezhetö, hogy sok mindenben másként gondolkodnak, és valószínüleg a diszruptív innovációhoz füződő viszonyuk is eltér attól, amit jelen kutatásban feltártam. 


\section{Mellékletek}

\section{Hivatkozás jegyzék}

Achrol, R. S. (1991). Evolution of the marketing organization: new forms for turbulent environments. The Journal of Marketing, 77-93.

Adner, R. (2016). Navigating the Leadership Challenges of Innovation Ecosystems. MIT Sloan Management Review, 58(1).

Adner, R. (2017). Ecosystem as structure: An actionable construct for strategy. Journal of Management, 43(1), 39-58.

Agnihotri, R., Dingus, R., Hu, M. Y., \& Krush, M. T. (2016). Social media: Influencing customer satisfaction in B2B sales. Industrial Marketing Management, $53,172-180$.

Akehurst, G. (2009). User generated content: the use of blogs for tourism organisations and tourism consumers. Service Business, 3(1), 51-61.

Aldag, R. J.,\& Fuller, S. R. (1993). Beyond fiasco: A reappraisal of the groupthink phenomenon and a new model of group decision processes. Psychological Bulletin, 113(3), 533 .

Anderson, T. (2016). Theories for learning with emerging technologies. Emergence and innovation in digital learning: Foundations and applications, 35-50.

Antal, Z. (2006). A szervezeti struktúra mint a stratégia megvalósítását támogató eszköz. Versenyben a világgal 2004 - 2006 gazdasági versenyképességünk vállalati nézőpontból címü kutatás. 40. sz. mühelytanulmány Elérhető: http://edok.lib.unicorvinus.hu/182/1/40_mht_antal_zs.pdf

Argote, L. (2012). Organizational learning: Creating, retaining and transferring knowledge. Springer Science \& Business Media.

Aula, P. (2010). Social media, reputation risk and ambient publicity management. Strategy \& Leadership, 38(6), 43-49.

Aula, P., Laaksonen, S-M., Neiglick, S., (2010). Reputational risks and the rising power of digital publicity EUPRERA Congress 2010 
Baker, W. E.,\& Sinkula, J. M. (1999). The synergistic effect of market orientation and learning orientation on organizational performance. Journal of the academy of marketing science, 27(4), 411-427.

Barefoot, D., Szabo, J. (2010). Friends with benefits: A social media marketing handbook. No Starch Press.

Bauer, A. \&Berács, J. (2016). Marketing. Akadémiai K.

Bernoff, J., \& Li, C. (2008). Groundswell: Winning in a world transformed by social technologies. Boston: Harvard Business School Publishing.

Bickart, B., \& Schindler, R. M. (2001). Internet forums as influential sources of consumer information. Journal of interactive marketing, 15(3), 31-40. Bodon, F. (2010). Adatbányászati

algoritmusok.

Elérhető: http://www.cs.bme.hu/ bodon/magyar/adatbanyaszat/tanulmany/adatbanyaszat.pd f Letöltve: 2018. 06. 03.

Bolton, R. N., Parasuraman, A., Hoefnagels, A., Migchels, N., Kabadayi, S., Gruber, T., \& Solnet, D. (2013). Understanding Generation Y and their use of social media: a review and research agenda. Journal of service management, 24(3), 245267.

Bower, J. L., \& Christensen, C. M. (1995). Disruptive technologies: catching the wave.

Bradley, A. J. (2011). Master Six Core Principles to Trap the Massive Power of Social Media. Gartner Research Note. Elérhető: http://www.gartner.com/newsroom/id/2138415. Letöltve: 2017. 07. 23.

Bronner, F., \& de Hoog, R. (2014). Social media and consumer choice. International Journal Of Market Research, 56(1), 51-71.

Bronstein, J. (2014). Creating possible selves: information disclosure behaviour on social networks. Information Research, 19(1), 19-1.

Bruhn, M., Schoenmueller, V., \& Schäfer, D. B. (2012). Are Social Media replacing traditional media in terms of brand equity creation?. Management Research Review, 35(9), 770-790.

Bunderson, J. S., \& Boumgarden, P. (2010). Structure and learning in self-managed teams: Why "bureaucratic" teams can be better learners. Organization Science, 21(3), 609-624. 
Burns, T. E.,\& Stalker, G. M. (1961). The management of innovation.

Casaló, L. V., Flavián, C., \& Guinalíu, M. (2011). Understanding the intention to follow the advice obtained in an online travel community. Computers in Human Behavior, 27(2), 622-633.

Chau, Y. C., Kwong, K. F., Cao, C. R., Chauh, K. B., \& Law, K. M. (2015). Implementation of PAL in a Learning Organization. In PAL Driven Organizational Learning: Theory and Practices (pp. 51-92). Springer, Cham.

Cheung, C. M., Chiu, P. Y., \& Lee, M. K. (2011). Online social networks: why do students use Facebook?. Computers in Human Behavior, 27(4), 1337-1343.

Chiou, J. S., \& Cheng, C. (2003). Should a company have message boards on its web sites?. Journal of Interactive Marketing, 17(3), 50-61.

Choi, Y., \& Thoeni, A. (2016). Social media: is this the new organizational stepchild?. European Business Review, 28(1), 21-38.

Christodoulides, G. (2009). Branding in the post-internet era. Marketing Theory, 9(1), 141-144.

Church, A. H., \& Burke, W. W. (2017). Four trends shaping the future of organizations and organization development. OD Practitioner, 49(3), 14-22.

Colicev, A., Malshe, A., Pauwels, K., \& O’Connor, P. (2018). Improving Consumer Mindset Metrics and Shareholder Value Through Social Media: The Different Roles of Owned and Earned Media. Journal of Marketing, 82(1), 37-56.

Constantinides, E., \& Fountain, S. J. (2008). Web 2.0: Conceptual foundations and marketing issues. Journal of direct, data and digital marketing practice, 9(3), 231244.Clayton, B., Fisher, T., Harris, R., Bateman, A., \& Brown, M. (2008). Structures and Cultures: A Review of the Literature. Support Document 2. National Centre for Vocational Education Research (NCVER).

Cresswell, J. W., \& David , J. (2018). Research design: qualitative, quantitative, and mixed methods approaches. SAGE (USA).

Csepeti, Á. (2010). A Miles és Snow-féle stratégiatipológia kutatási kérdései (Research issues of Miles and Snow strategic typology). Vezetéstudomány/Budapest Management Review, 41(11), 15-30.

Dahl, S. (2018). Social media marketing: Theories and applications. Sage. 
Davis, J. P. (2016). The group dynamics of interorganizational relationships: Collaborating with multiple partners in innovation ecosystems. Administrative Science Quarterly, 61(4), 621-661.

Day, G. S. (1994). Continuous learning about markets. California management review, 36(4), 9-31.

Debatin, B. (2011). Ethics, privacy, and self-restraint in social networking. InPrivacy online (pp. 47-60). Springer Berlin Heidelberg.

Dedrick, J., Gurbaxani, V., \& Kraemer, K. L. (2003). Information technology and economic performance: A critical review of the empirical evidence. ACM Computing Surveys (CSUR), 35(1), 1-28.

Dellarocas, C. (2003). The digitization of word of mouth: Promise and challenges of online feedback mechanisms. Management science, 49(10), 1407-1424.

Denscombe, M. (2008). Communities of practice: A research paradigm for the mixed methods approach. Journal of mixed methods research, 2(3), 270-283.

Dong, J. Q.,\& Wu, W. (2015). Business value of social media technologies: Evidence from online user innovation communities. The Journal of Strategic Information Systems, 24(2), 113-127.

Duggan M., Ellison N.B., Lampe C., Lenhart A., Madden M. (2015). Demographics of Key Social Networking Platforms. PewResearch. Elérhető: http://www.pewinternet.org/2015/01/09/demographics-of-key-social-networkingplatforms-2/ Letöltve: 2015. 07. 21.

Easterby-Smith, M., \& Prieto, I. M. (2008). Dynamic capabilities and knowledge management: an integrative role for learning? British journal of management, 19(3), 235-249.

Easterby-Smith, M., Crossan, M., \& Nicolini, D. (2000). Organizational learning: debates past, present and future. Journal of management studies, 37(6), 783-796. Edmondson, A. (1999). Psychological safety and learning behavior in work teams. Administrative science quarterly, 44(2), 350-383.

Ellison, N. B. (2007). Social network sites: Definition, history, and scholarship.Journal of Computer-Mediated Communication, 13(1), 210-230.

Erragcha, N., Romdhane, R. (2014). Social Networks as Marketing Tools. Journal of Internet Banking and Commerce, 19(1) 
Etter, M., \& Colleoni, E. Social Media Reputation: Social Media as a Data Source for Corporate Reputation Measurement. In Reputation Institute Global Annual Conference 2013.

Fang, C. (2012). Organizational learning as credit assignment: A model and two experiments. Organization Science, 23(6), 1717-1732.

Fang, C., Lee, J., \& Schilling, M. A. (2010). Balancing exploration and exploitation through structural design: The isolation of subgroups and organizational learning. Organization Science, 21(3), 625-642.

Fehér, K., 2012. Az internettől az új médiáig. Századvég, 4. kötet, pp. 3-18.

Fehér, P., Szabó, Z., \& Varga, K. (2017). Analysing Digital Transformation among Hungarian Organizations.

Felix, R., Rauschnabel, P. A., \& Hinsch, C. (2017). Elements of strategic social media marketing: A holistic framework. Journal of Business Research, 70, 118126.

Flew, T. (2017). Social media and the cultural and creative industries. In SAGE Handbook of Social Media (pp. 512-526). SAGE Publications Inc.

Fossen, B. L., \& Schweidel, D. A. (2016). Television Advertising and Online Word-of-Mouth: An Empirical Investigation of Social TV Activity. Marketing Science.

Garvin, D. A. (1993). Building a learning organization (Vol. 71, No. 4, pp. 78-91). July-August: Harvard Business Review.

Ghezzi, A., Gastaldi, L., Lettieri, E., Martini, A., \& Corso, M. (2016). A role for startups in unleashing the disruptive power of social media. International Journal of Information Management, 36(6), 1152-1159.

Gilmore, J. H., \& Pine 2nd, B. J. (1996). The four faces of mass customization.Harvard business review, 75(1), 91-101.

Grönroos, C. (1994). From marketing mix to relationship marketing: towards a paradigm shift in marketing. Management decision, 32(2), 4-20.

Gyulavári, T., Mitev, A., Neulinger, Á., Neumann-Bódi, E., Simon, J., \& Szűcs, K. (2012). A marketing kutatás alapjai. Bologna Tankönyvsorozat, Budapest, Aula Kiadó. 
Guimaraes, T. (2014). The social-media demographics report: Differences in gender, age, and income at the top networks. Business Insider.

Hágen, I. Z., \& Holló, E. (2017). A hazai KKV-k helyzete, a versenyképesség, innováció és controlling tükrében. Controller info, 5(1.).

Hamill, J. (2016). 17 The end of marketing as usual. The Marketing Book, 415.

Hamilton, M., Kaltcheva, V. D., \& Rohm, A. J. (2016). Social media and value creation: the role of interaction satisfaction and interaction immersion. Journal of Interactive Marketing, 36, 121-133.

Hanna, R., Rohm, A., \& Crittenden, V. L. (2011). We're all connected: The power of the social media ecosystem. Business horizons, 54(3), 265-273.

Hassan, S., Nadzim, S. Z. A.,\& Shiratuddin, N. (2015). Strategic use of social media for small business based on the AIDA model. Procedia-Social and Behavioral Sciences, 172, 262-269.

Henderson, J. C., \& Venkatraman, H. (1993). Strategic alignment: Leveraging information technology for transforming organizations. IBM systems journal, $32(1), 472-484$.

Herendy, Cs. (2010): A kereső, a dokumentumok és a user. A szemantikus web egy lehetséges nézőpontja. Médiakutató vol. 2010/1. Elérhető: http://www.mediakutato.hu/cikk/2010_01_tavasz/03_szemantikus_web Letöltve: 2017. 05. 10.

Hoffman, D. L., \& Fodor, M. (2010). Can you measure the ROI of your social media marketing?. MIT Sloan Management Review, 52(1), 41. Holloman, C. (2011). The Social Media MBA: Your Competitive Edge in Social Media Strategy Development and Delivery. John Wiley \& Sons.

Holland, C. R., \& Light, B. (1999). A critical success factors model for ERP implementation. IEEE software, 16(3), 30-36.

Hong, K. K., \& Kim, Y. G. (2002). The critical success factors for ERP implementation: an organizational fit perspective. Information \& Management, 40(1), 25-40.

Huberman, B. A. (2001). The dynamics of organizational learning. Computational \& Mathematical Organization Theory, 7(2), 145-153.

Hubert, J. (2018): Corporate self-disclosure in social media. Megjelenés elött. 
Hult, G. T. M. (2011). Toward a theory of the boundary-spanning marketing organization and insights from 31 organization theories. Journal of the Academy of Marketing Science, 39(4), 509-536.

Hunt, T. (2009). The whuffie factor: Using the power of social networks to build your business. Crown Pub.

Hurley, R. F.,\& Hult, G. T. M. (1998). Innovation, market orientation, and organizational learning: an integration and empirical examination. The Journal of marketing, 42-54.

Iansiti, M., \& Levien, R. (2004). The keystone advantage: what the new dynamics of business ecosystems mean for strategy, innovation, and sustainability. Harvard Business Press.

Jansen, J. J., Van Den Bosch, F. A.,\& Volberda, H. W. (2006). Exploratory innovation, exploitative innovation, and performance: Effects of organizational antecedents and environmental moderators. Management science, 52(11), 16611674.

John, W., Creswell, C., \& David, J. (2018). Research design: qualitative, quantitative, and mixed methods approaches. Sage Publications (USA).

Johnson, B., \& Christensen, L. (2008). Educational research: Quantitative, qualitative, and mixed approaches. Sage.

Johnson, R. B., Onwuegbuzie, A. J., \& Turner, L. A. (2007). Toward a definition of mixed methods research. Journal of mixed methods research, 1(2), 112-133.

Kane, A. A. (2010). Unlocking knowledge transfer potential: Knowledge demonstrability and superordinate social identity. Organization Science, 21(3), 643-660.

Kaplan, A. M., \& Haenlein, M. (2010). Users of the world, unite! The challenges and opportunities of Social Media. Business horizons, 53(1), 59-68.

Keegan, B., \& Rowley, J. (2017). Co-creation in Social Media Marketing Strategy:

Re-evaluating the Agency-Client Relationship, An Extended Abstract. In Marketing at the Confluence between Entertainment and Analytics (pp. 13311335). Springer, Cham.

Keith, R. J. (1960). The marketing revolution. The Journal of Marketing, 35-38. 
Kim, A. J., \& Ko, E. (2012). Do social media marketing activities enhance customer equity? An empirical study of luxury fashion brand. Journal of Business Research, 65(10), 1480-1486.

Kim, J. H., Kim, M. S., \& Nam, Y. (2010). An analysis of self-construals, motivations, Facebook use, and user satisfaction. Intl. Journal of HumanComputer Interaction, 26(11-12), 1077-1099.

Kotler, P., Keller, K., Ang, S., Leong, S., \& Tan, C. T. (2008). Marketing Management an Asian Perspectives, PearsonEducation.

Kowalkowski, C., Persson Ridell, O., Röndell, J. G., \& Sörhammar, D. (2012). The co-creative practice of forming a value proposition. Journal of marketing management, 28(13-14), 1553-1570.

Krush, M. T., Sohi, R. S., \& Saini, A. (2015). Dispersion of marketing capabilities: impact on marketing's influence and business unit outcomes. Journal of the Academy of Marketing Science, 43(1), 32-51.

Kujath, C. L. (2011). Facebook and MySpace: Complement or substitute for faceto-face interaction?. Cyberpsychology, Behavior, and Social Networking,14(1-2), $75-78$.

Kumar, A., Bezawada, R., Rishika, R., Janakiraman, R., \& Kannan, P. K. (2016). From social to sale: The effects of firm-generated content in social media on customer behavior. Journal of Marketing, 80(1), 7-25.

Kuss, D. J., \& Griffiths, M. D. (2011). Online social networking and addiction-a review of the psychological literature. International journal of environmental research and public health, 8(9), 3528-3552.

Lam, A. (2000). Tacit knowledge, organizational learning and societal institutions: An integrated framework. Organization studies, 21(3), 487-513.Lamberton, C., \& Stephen, A. T. (2016). A Thematic Exploration of Digital, Social Media, and Mobile Marketing: Research Evolution from 2000 to 2015 and an Agenda for Future Inquiry. Journal of Marketing, 80(6), 146-172.

Lang, M., \& Pätzold, G. (2004). Neue Wege zum Erwerb von Arbeitsprozesswissen in hochautomatisierten Produktionsprozessen der Chemischen Industrie: Die Eignung netzbasierter Lernumgebungen zur Verknüpfung von formellem und 
informellem Lernen im Arbeitsprozess. Innovationen und Tendenzen der betrieblichen Berufsbildung. Stuttgart: Franz Steiner, 97-106.

Lawrence, P. R.,\& Lorsch, J. W. (1969). Developing organizations: Diagnosis and action.

Lee, S., Hwang, T., \& Lee, H. H. (2006). Corporate blogging strategies of the Fortune 500 companies. Management Decision, 44(3), 316-334.

$\mathrm{V}$

Lemon, K. N., Rust, R. T., \& Zeithaml, V. A. (2001). What drives customer equity. Marketing management, 10(1), 20.

Lenhard A. (2015): Mobile Access Shifts Social Media Use and Other Online Activities.

PewResearch.

Elérhető:

http://www.pewinternet.org/2015/04/09/mobile-access-shifts-social-media-use-

and-other-online-activities/ Letöltve: 2015. 07. 21.

Levin, D. Z.,\& Cross, R. (2004). The strength of weak ties you can trust: The mediating role of trust in effective knowledge transfer. Management science, 50(11), 1477-1490.

Levy, M. (2009). WEB 2.0 implications on knowledge management. Journal of knowledge management, 13(1), 120-134.

Lichtman, M. (2006). Qualitative research: A user's guide.

Lin, H., Fan, W., \& Chau, P. Y. (2014). Determinants of users' continuance of social networking sites: A self-regulation perspective. Information \& Management, 51(5), 595-603.

Lis, B., \& Horst, M. (2013). Electronic word of mouth impacts: a spotlight on customer integration. Journal of Media Business Studies, 10(4).

Liu, G.,\& Ko, W. W. (2012). Organizational learning and marketing capability development: A study of the charity retailing operations of British social enterprise. Nonprofit and Voluntary Sector Quarterly, 41(4), 580-608.

Luckerson, V. (2014). 7 Controversial Ways Facebook Has Used Your Data. Elérhetö: $\quad$ http://time.com/4695/7-controversial-ways-facebook-has-used-yourdata/ Letöltve: 2015. 07. 21.

Luo, X., Zhang, J., \& Duan, W. (2013). Social media and firm equity value. Information Systems Research, 24(1), 146-163. 
Malhotra, N. K., \& Simon, J. (2008). Marketingkutatás. Akadémiai Kiadó.

Mangold, W. G., \& Faulds, D. J. (2009). Social media: The new hybrid element of the promotion mix. Business horizons, 52(4), 357-365.Markos-Kujbus, É. (2016). $\mathrm{Az}$ on-line szájreklám (electronic word-of-mouth) jellemzői a marketingkommunikáció szempontjából. Vezetéstudomány/Budapest Management Review, 47(6), 52-63.

Marquardt, M. J. (2011). Building the learning organization: Mastering the five elements for corporate learning. Hachette UK.

Mertens, D. M. (2010). Transformative mixed methods research. Qualitative inquiry, 16(6), 469-474.

Miles, R. E., Snow, C. C., Meyer, A. D., \& Coleman, H. J. (1978). Organizational strategy, structure, and process. Academy of management review, 3(3), 546-562.

Minazzi, R. (2015). Social media marketing in tourism and hospitality. Heidelberg: Springer.

Mintzberg, H., Ahlstrand, B., \& Lampel, J. (2009). Strategy safari: Your complete guide through the wilds of strategic management. Pearson Education Limited, Upper Saddle River.

Mintzberg, H., Quinn, J. B., \& Ghoshal, S. (1998). The strategy process. Revised European edition. Hemel Hempstead, UK: Prentice Hall.

Mintzberg, H.,\& Waters, J. A. (1985). Of strategies, deliberate and emergent. Strategic management journal, 6(3), 257-272.

Miranda, S. M., Young, A., \& Yetgin, E. (2016). Are social media emancipatory or hegemonic? Societal effects of mass media digitization. MIS Quarterly, 40(2), 303329.

Montalvo, R. E. (2016). Social media management. International Journal of Management \& Information Systems (Online), 20(2), 45.

Morse, J. M., \& Niehaus, L. (2009). Principles and procedures of mixed methods design.

Murthy, D., \& Lewis, J. P. (2015). Social media, collaboration, and scientific organizations. American Behavioral Scientist, 59(1), 149-171.

Muth, J. F. (1986). Search theory and the manufacturing progress function. Management Science, 32(8), 948-962. 
Nah, F. F. H., Zuckweiler, K. M., \& Lee-Shang Lau, J. (2003). ERP implementation: chief information officers' perceptions of critical success factors. International journal of Human-computer Interaction, 16(1), 5-22.

Nambisan, P., \& Watt, J. H. (2011). Managing customer experiences in online product communities. Journal of Business Research, 64(8), 889-895.

O'Reilly, T., 2005. What Is Web 2.0? (2005) Design Patterns and Business Models for the Next Generation of Software. Elérhetö: http://www.oreilly.com/pub/a/web2/archive/what-is-web-20.html Letöltve: 2015 március 15.

O'Reilly, T. (2006). Levels of the game: The hierarchy of Web 2.0 applications. Online version: radar. oreilly. com/archives/2006/07/levels_of_the_game. html.

Olson, E. M., Slater, S. F.,\& Hult, G. T. M. (2005). The performance implications of fit among business strategy, marketing organization structure, and strategic behavior. Journal of marketing, 69(3), 49-65.

Onishi, H., \& Manchanda, P. (2012). Marketing activity, blogging and sales. International Journal of Research in Marketing, 29(3), 221-234.

Örtenblad, A. (Ed.). (2013). Handbook of research on the learning organization: Adaptation and context. Edward Elgar Publishing.

Papacharissi, Z., \& Gibson, P. L. (2011). Fifteen Minutes of Privacy: Privacy, Sociality, and Publicity on Social Network Sites.

Park, D. H., \& Kim, S. (2009). The effects of consumer knowledge on message processing of electronic word-of-mouth via online consumer reviews. Electronic Commerce Research and Applications, 7(4), 399-410.

Payne, A. F., Storbacka, K., \& Frow, P. (2008). Managing the co-creation of value. Journal of the academy of marketing science, 36(1), 83-96.

Pedler, M., \& Burgoyne, J. G. (2017). Is the learning organisation still alive?. The Learning Organization, 24(2), 119-126.

Pegoraro, A. (2014). Twitter as disruptive innovation in sport communication. Communication \& Sport, 2(2), 132-137. 
Pemberton, J. D., \& Stonehouse, G. H. (2000). Organisational learning and knowledge assets-an essential partnership. The learning organization, 7(4), 184194.

PR, Newswire. "The Digital Marketing Exchange; Europe's Most Prestigious Meeting for Cmos, Cios and Leaders of Digital Marketing, Mobile Marketing and Social Media." ["bc-The-Digital-Marketing"]. PR Newswire US, 26 June 2014 Raacke, J., \& Bonds J. (2008). MySpace and Facebook: Applying the uses and gratifications theory to exploring friend-networking sites.Cyberpsychology \& behavior, 11(2), 169-174.

Rényi, Z. (2011). Közösségi tervezés 2.0: a participáció új perspektívái a webkettő fényében. Tér és Társadalom, 25(3), 100-116.

Reynolds, N. S. (2015). Making sense of new technology during organisational change. New Technology, Work and Employment, 30(2), 145-157.

Rondell, J. G., \& Sorhammar, D. (2010). Functional identities, resource integrators and the service-dominant logic. Journal of Customer Behaviour, 9(1), 19-36.

Ross, C., Orr, E. S., Sisic, M., Arseneault, J. M., Simmering, M. G., \& Orr, R. R. (2009). Personality and motivations associated with Facebook use. Computers in human behavior, 25(2), 578-586.

Sayre, S. (2001). Qualitative methods for marketplace research. Thousand Oaks, CA: Sage.

Schuchmann, D., \& Seufert, S. (2015). Corporate learning in times of digital transformation: a conceptual framework and service portfolio for the learning function in banking organisations. International Journal of Corporate Learning (iJAC), 8(1), 31-39.

Senge P. M. (1998): Az 5. alapelv - A tanuló szervezet kialakításának elmélete és gyakorlata. HVG Kiadó, Budapest

Senge, P. M. (2014). The fifth discipline fieldbook: Strategies and tools for building a learning organization. Crown Business.

Skarzynski, P., \& Rufat-Latre, J. (2011). Lessons to jumpstart disruptive innovation. Strategy \& Leadership, 39(1), 5-10.

Slater, S. F.,\& Narver, J. C. (1995). Market orientation and the learning organization. The Journal of marketing, Vol. 59. 63-74. 
Sledgianowski, D., \& Kulviwat, S. (2009). Using social network sites: The effects of playfulness, critical mass and trust in a hedonic context. The Journal of Computer Information Systems, 49(4), 74.

Stephen, A. T., \& Galak, J. (2012). The effects of traditional and social earned media on sales: A study of a microlending marketplace. Journal of Marketing Research, 49(5), 624-639.

Stephen, A. T., Zubcsek, P. P., \& Goldenberg, J. (2016). Lower connectivity is better: The effects of network structure on redundancy of ideas and customer innovativeness in interdependent ideation tasks. Journal of Marketing Research, 53(2), 263-279.

Subrahmanyam, K., Reich, S. M., Waechter, N., \& Espinoza, G. (2008). Online and offline social networks: Use of social networking sites by emerging adults. Journal of Applied Developmental Psychology, 29(6), 420-433.

Szerb, L. (2017). A vállalkozói ökoszisztéma Magyarországon a 2010-es évekbenhelyzetértékelés és szakpolitikai javaslatok. Vezetéstudomány/Budapest Management Review, 48(6-7), 2-14.

Sztárayné, K. É. (2011): Kvantitatív és kvalitatív kutatási módszerek. Elérhető: http://igyk.pte.hu/files/tiny_mce/File/kari_projektek/informaciotudaservenyesules /tananyagok/1_alprojekt/KM/05 kutatasmodszertan5 kvalitativ_modszerek.pdf

Letöltve: 2017. 12. 13.

Szücs, Zoltán (2012): Az internetes kommunikáció története és elmélete. Médiakutató $\quad$ vol. 2012/1. Elérhetö: http://www.mediakutato.hu/cikk/2012_01_tavasz/01_internetes_kommunikacio_t ortenete Letöltve: 2017. 05. 10.

Tam, S.,\& Gray, D. E. (2016). Organisational learning and the organisational life cycle: the differential aspects of an integrated relationship in SMEs. European Journal of Training and Development, 40(1), 2-20.

Teixeira, T. (2015). A New Wave of Digital Disruption Models. Presentation, Arizona Biltmore.

Thelwall, M. (2009). Social network sites: Users and uses. Advances in computers, $76,19-73$. 
Thompson, J. D., \& Bates, F. L. (1957). Technology, organization, and administration. Administrative Science Quarterly, 325-343.

Tomas, G., Hult, M., \& Morgan, A. J. (2015). Total Learning Marketing. In Proceedings of the 1996 Academy of Marketing Science (AMS) Annual Conference (pp. 138-143). Springer, Cham.

Tomas, G., Hult, M., \& Morgan, A. J. (2015). Total Learning Marketing. In Proceedings of the 1996 Academy of Marketing Science (AMS) Annual Conference (pp. 138-143). Springer, Cham.

Ton, Z.,\& Huckman, R. S. (2008). Managing the impact of employee turnover on performance: The role of process conformance. Organization Science, 19(1), 5668.

Tosey, P., Visser, M., \& Saunders, M. N. (2012). The origins and conceptualizations of 'triple-loop'learning: A critical review. Management Learning, 43(3), 291-307.

Trainor, K. J. (2012). Relating social media technologies to performance: A capabilities-based perspective. Journal of Personal Selling \& Sales Management, 32(3), 317-331.

Trusov, M., Bucklin, R. E., \& Pauwels, K. (2009). Effects of word-of-mouth versus traditional marketing: Findings from an internet social networking site. Journal of marketing, 73(5), 90-102.

Tuten, T. L. (2008). Advertising 2.0. Wesport, CT.: Praeger.

Van der Lans, R., Van Bruggen, G., Eliashberg, J., \& Wierenga, B. (2010). A viral branching model for predicting the spread of electronic word of mouth. Marketing Science, 29(2), 348-365.

Vassileva, B. (2017). Marketing 4.0: How technologies transform marketing organization. Obuda University e-Bulletin, 7(1), 47.

Vorhies, D. W.,\& Morgan, N. A. (2003). A configuration theory assessment of marketing organization fit with business strategy and its relationship with marketing performance. Journal of marketing, 67(1), 100-115.

Walther, J. B. (2011). Introduction to privacy online. In Privacy Online (pp. 3-8). Springer Berlin Heidelberg. 
Weinberg, T. (2009). The new community rules: Marketing on the social web. " O'Reilly Media, Inc.".

Weldon, M. S.,\& Bellinger, K. D. (1997). Collective memory: collaborative and individual processes in remembering. Journal of experimental psychology: Learning, memory, and cognition, 23(5), 1160.

West, J., \& Wood, D. (2014). Evolving an open ecosystem: The rise and fall of the Symbian platform. In Collaboration and competition in business ecosystems (pp. 27-67). Emerald Group Publishing Limited.

Wilden, R., Gudergan, S. P., Nielsen, B. B., \& Lings, I. (2013). Dynamic capabilities and performance: strategy, structure and environment. Long Range Planning, 46(1-2), 72-96.

Yang J., Mai E., Ben-Ur J.(2011), Did you tell me the truth? The influence of online community on eWOM, "International Journal of Marketing Research", vol. 52, issue 3, pp. $369-386$.

Yang, B., Watkins, K. E.,\& Marsick, V. J. (2004). The construct of the learning organization: Dimensions, measurement, and validation. Human resource development quarterly, 15(1), 31-55.

Yao, M. Z. (2011). Self-protection of online privacy: A behavioral approach. InPrivacy Online (pp. 111-125). Springer Berlin Heidelberg.

Yarbrough, L., Morgan, N. A.,\& Vorhies, D. W. (2011). The impact of product market strategy-organizational culture fit on business performance. Journal of the Academy of Marketing Science, 39(4), 555-573.

Yin, R. K. (2017). Case study research and applications: Design and methods. Sage publications.

Zahra, S. A., Sapienza, H. J.,\& Davidsson, P. (2006). Entrepreneurship and dynamic capabilities: A review, model and research agenda. Journal of Management studies, 43(4), 917-955.

Zammuto, R. F., Griffith, T. L., Majchrzak, A., Dougherty, D. J., \& Faraj, S. (2007). Information technology and the changing fabric of organization. Organization science, 18(5), 749-762. 
Zeleny, M. (2012). High technology and barriers to innovation: From globalization to relocalization. International Journal of Information Technology \& Decision Making, 11(02), 441-456.

Zheleva, E., \& Getoor, L. (2009). To join or not to join: the illusion of privacy in social networks with mixed public and private user profiles. In Proceedings of the 18th international conference on World wide web (pp. 531-540). ACM.

Zollo, M., \& Winter, S. G. (2002). Deliberate learning and the evolution of dynamic capabilities. Organization science, 13(3), 339-351.

\section{Szakértői mélyinterjúk vezérfonala}

\section{Közösségi média helye a reklámstratégiában}

A doktori disszertáció központi témája a közösségi média szerepe a vállalat marketing tevékenységében, azon belül is első sorban a reklámstratégiában.

A fő kérdést eltérő irányokból vizsgálom:

1. Milyen vállalati célok támogatására alkalmas a közösségi média? Alkalmas lehet-e például:

1. márkaépítésre

2. értékesítés-támogatásra

3. reputáció menedzsmentre ill. ezzel kapcsolatos kockázatok kezelésére

4. közösség építésre

5. piaci insight forrása

6. vevőszolgálattal összefüggő feladatok ellátására

Hol vannak a hangsúlyok ma, van-e történeti fejlődés?

\section{Szervezeti kérdések}

1. Mi az, amit a telkom szektorban ma egy vállalatnak „kötelező” csinálnia a közösségi médiában? 
2. Milyen módon hatnak a telkom iparág szereplő (közvetlen versenytársak) egymásra?

3. Milyen képességekre van szükség a közösségi média kezeléséhez, mennyiben új ez a korábbi követelményekhez képest?

4. Közösségi média kezelése: házon belül vagy outsource-olva?

- Esetleg: eltérő területek (ld 1-es pont) eltérő módon kezelve?

1. Amennyiben házon belül, úgy melyik szervezeti egység alá tartozik (marketing, kommunikáció, IT)?

2. Sokan nagy szervezeti átalakulásokat vízionálnak - látni ennek elöjeleit? Lesz ebböl valami?

3. Milyen szinten áll a KM munkatárs (trainee, menedzser, stb)?

\section{Reklámcélok}

1. Milyen lényegi különbséget lát

1. Közösségi média és egyéb internetes hirdetési formák (pl. kereső hirdetés, bannerek, stb)

2. Közösségi média és egyéb reklámhordozók (pl. TV,

2. Van-e Ön szerint kimutatható WoM hatás? Mérik-e, fontos-e a fogyasztók egymás közötti kommunikációja?

3. Mi a helyzet a fogyasztóktól a vállalatok irányába mutató kommunikációval?

4. Mennyiben ért egyet azzal, hogy korábban (KM előtt) a vállalatok uralták a fogyasztókkal történő kommunikációt, ma a helyzet éppen fordított?

5. Képesek-e kezelni a fogyasztók részéről érkező negatív visszacsatolásokat

\section{Közösség menedzselése}

1. Mi a vállalat célja a KM részvétellel?

2. Részvétel szintjei: 
1. Tudatosan nem vesz részt (pl. bankok)

2. Részt vesz, de csupán egy irányú kommunikációt folytat (közlő -> befogadó)

3. Interakcióra épít

4. Önálló tartalmak készítésére buzdítja a közösség tagjait (pl. co-creation)

3. Kockázatok és kezelésük

\section{Fogyasztói pszichológia}

1. Figyelembe veszik-e a fogyasztók pszichográfiai jellemzőit a KM stratégia alkotásban?

1. Közösségi média pszichológiája

2. Közösségi média használatának motivációja és haszna

3. Magatartásminták a közösségi oldalakon

Milyen módon viszonyul a cég az eWOM-hoz (elektronikus szájreklám)?

\section{Vállalati esettanulmány - feladatkiírás}

A kutatási projekt a digitális átalakulás marketinget és üzletvitelt érintő kérdéseit elemzi. A dolgozatot saját tapasztalatára, illetve kutatására alapozva kell kidolgozni egy vállalat, illetve ennek hiányában egy iparág esetében. A dolgozatot - amelynek szerkezetére az alábbiakban találhat információt - 2018. május 2-ig kell a tárgy Moodle honlapjára feltölteni. A dolgozat terjedelme 15 oldal, a felhasznált forrásokat megfelelően hivatkozni kell.

\section{Marketingszervezetek átalakulása a digitális forradalomban}

A szakirodalom a DSMM - Digital, Social Media, Mobile marketing összefoglaló névvel illeti azokat az új marketing technikákat (technológiákat), melyek a digitális forradalom révén „keletkeztek” - és amelyek napjainkra alaposan átrendezték a piaci és szervezeti viszonyokat. Ebbe a kategóriába sorolható a vállalati honlap, microsite, hírlevél (emailben), keresőmarketing (hirdetések és optimalizálás), 
közösségi média marketing (tartalom generálás, hirdetések), mobil eszközökön való megjelenés (saját alkalmazás, mobil hirdetések, helyzet függő hirdetések, stb).A feladat kidolgozása során ne csak az „aktív” (tartalomelőállítást célzó) marketing felhasználásra gondoljon, hanem a passzív figyelésre is (pl. social listening, vevő- és versenytárs figyelés, lead generálás, közösségi „,vevőszolgálat”, stb).

\section{A dolgozat javasolt szerkezete}

0. Bevezetés A szervezet profilja, jellemző adatai, piaci helyzete, marketing jellemzői

\section{Feladatok, készségek}

1. Jelentek-e meg olyan új feladatok a szervezetek számára a DSMM révén, melyek teljesen vagy részben új típusú készségek meglétét követelték meg a cégtől? (banner készítés csak részben új, amennyiben hasonló kreatívokat - pl. óriásplakát formájában - már korábban is kellett készítsenek a cégek. A közösségi média tartalomgyártás lehet teljesen új, amennyiben korábban nem volt az jellemző, hogy napi rendszerességgel híreket adjanak magukról a vevőközönségük felé)

2. Hogyan jelenik meg a szervezet müködésében az analytics, azaz számos forrásból származó nagytömegü információ felhasználása marketing feladatok ellátására (Gondoljon pl. a Big Data alkalmazásokra, külső források adatbányászására, közösségi média adatok hagyományos adatokkal való összekapcsolására)

3. A DSMM (digitális) korszak előtti állapotokhoz képest van-e változás a környezeti feltételekben (kiszámíthatóság, tervezhetőség, előreláthatóság, stb)?

4. Milyen (új/régi) vezetői készségek kellenek ahhoz, hogy a megváltozott környezetben a vállalat sikeres tudjon maradni?

5. Milyen új tudás, képesség szükséges a dolgozók részéről a cég sikeréhez? A szervezeti átalakulás során gondoljon arra, hogy amikor egy szervezetnek új típusú tudást kell beépítenie a napi müködésbe, akkor lehetősége van azt külső illetve 206 
belső szervezeti formában is megoldania (pl. ügynökség, tanácsadó igénybevételével vs. saját munkavállaló alkalmazása).

\section{Szervezeti átalakulás}

6. Tapasztal-e olyan jelenséget, ami arra utal, hogy a DSMM miatt a marketing osztály szervezeten belül betöltött helyzete megváltozik?

7. Tapasztal-e olyan jelenséget, ami arra utal, hogy a DSMM miatt a marketing feladatok szervezeten belüli helye megváltozik? (Fenti kérdésre példa lehet a közösségi médián - vállalati Facebook profilon keresztül - zajló álláshirdetés. Ez alapvetően HR feladat, ami azonban - a közösségi média miatt - már egyfajta marketing feladatként is értelmezhetö)

8. A szakirodalom szerint a különböző szervezeteknek saját, egyedi „mikrokultúrájuk” van. Például egy erősen hierarchia-orientált vállalatnál a tisztségeknek, rangnak nagyobb jelentősége van, mint mondjuk egy start-up cégnél. Vannak szervezetek, amelyek nyitottak az újdonságokra, másutt jóval konzervatívabb megközelítés a jellemző. Egy kisebb cég lehet, hogy könnyebben tud „felfedezőként” viselkedni, egy nagyobb cégnél nagyobb hangsúlyt tesznek a meglevő piaci pozíciók védelmére. Van, ahol a vezetési stílus tekintélyelvü (,az van, amit a fönök mond”), más szervezeteknél a munkavállalókat is bevonják a döntési folyamatokba...

Ez az egyedi kultúra időben nem feltétlenül állandó, akárcsak a környezeti kihívások miatt is a vállalatoknak ezen a területen is megújulásra lehet szükségük.

a. Tapasztalt-e változást akár a marketing osztály, akár a szervezet kultúrájában a DSMM marketing megjelenésével? (Különös tekintettel a közösségi médiára)

b. Ön szerint a szervezet kultúrájának a megváltozása hozzásegíthetné-e a szervezetet ahhoz, hogy a DSMM marketingben sikeresebben legyen? (Különös tekintettel a közösségi médiára)

III. Diszruptív innováció 
9. A szakirodalom szerint az innováció egy típusa az ún. disztruptív (romboló) innováció. Például amikor a Ford T-model, az első elérhető áron kínált autó megjelent, az néhány év alatt teljesen átalakította a közlekedési piacot. Ez nem csak a közvetlen vetélytársakat (pl. „hintósok”, stb) érintette, de azok beszállítói és egyéb kapcsolati hálózatát is (lótáp árusok, köztisztasági munkások, stb). Sokak szerint a digitális forradalom a marketing számára egy ilyen „romboló innováció”. Tapasztal-e olyan, a digitális eszköz marketinghez (internet, közösségi hálózatok, mobil) kapcsolható jelenségeket, amelyek a fenti példához hasonló lehet?

\title{
IV. Teljesítménymérés
}

10 . Hogyan mérik sikert / mivel mérhető a siker a.

\author{
a közösségi média- \\ b. kereső- \\ c. mobil marketingben? \\ Javasolt szakirodalom
}

Allen H. Church, W. Burke (2017): Four Trends Shaping the Future of Organizations and Organization Development, OD Practitioner, 49, 3,

Reto Felix, Philipp A. Rauschnabel, Chris Hinsch (2016): Elements of strategic social media marketing: A holistic framework, Journal of Business Research

Noelia-Sarah Reynolds (2015): Making sense of new technology during organisational change, New Technology, Work and Employment, 30,2, 145-159

Ashish Kumar, Ram Bezawada, Rishika Rishika, Ramkumar Janakiraman, PK Kannan (2016) From social to sale: The effects of firm-generated content in social media on customer behavior, Journal of Marketing, 2016/1, 7-25

PK Kannan (2017): Digital marketing: A framework, review and research agenda Digital marketing: A framework, review and research agenda International Journal of Research in Marketing, 2017/3/1 
4. Klaszter* egyéb változók kereszttábla

\begin{tabular}{|c|c|c|c|c|c|c|}
\hline \multicolumn{7}{|c|}{ Case Processing Summary } \\
\hline & \multirow{2}{*}{\multicolumn{2}{|c|}{ Valid }} & \multirow{2}{*}{\multicolumn{2}{|c|}{$\begin{array}{l}\text { Cases } \\
\text { Missing }\end{array}$}} & \multirow{2}{*}{\multicolumn{2}{|c|}{ Total }} \\
\hline & & & & & & \\
\hline & $\mathrm{N}$ & Percent & $\mathrm{N}$ & Percent & $\mathrm{N}$ & Percent \\
\hline Pozíció szintje * KLASZTER & 557 & $99.8 \%$ & 1 & $0.2 \%$ & 558 & $100.0 \%$ \\
\hline Szektor * KLASZTER & 534 & $95.7 \%$ & 24 & $4.3 \%$ & 558 & $100.0 \%$ \\
\hline Vevőkör * KLASZTER & 516 & $92.5 \%$ & 42 & $7.5 \%$ & 558 & $100.0 \%$ \\
\hline Tulajdonosi háttér * KLASZTER & 537 & $96.2 \%$ & 21 & $3.8 \%$ & 558 & $100.0 \%$ \\
\hline $\begin{array}{l}\text { Gyakorlati évek száma kategorizáció * } \\
\text { KLASZTER }\end{array}$ & 482 & $86.4 \%$ & 76 & $13.6 \%$ & 558 & $100.0 \%$ \\
\hline Álláshirdetés típusa * KLASZTER & 558 & $100.0 \%$ & 0 & $0.0 \%$ & 558 & $100.0 \%$ \\
\hline
\end{tabular}

\section{Pozíció szintje * KLASZTER}

\section{Crosstab}

\begin{tabular}{|c|c|c|c|c|c|c|}
\hline \\
\hline & & & & KLASZTER & & \\
\hline & & & $\begin{array}{l}\text { Marketing } \\
\text { végzettségű }\end{array}$ & $\begin{array}{c}\text { Mérnök- } \\
\text { informatikai } \\
\text { végzettségű }\end{array}$ & $\begin{array}{c}\text { SEO } \\
\text { szakértő }\end{array}$ & Total \\
\hline \multirow{3}{*}{$\begin{array}{l}\text { Pozíció } \\
\text { szintje }\end{array}$} & \multirow{3}{*}{$\begin{array}{l}\text { Gyakornok, } \\
\text { asszisztens }\end{array}$} & Count & 61 & 14 & 13 & 88 \\
\hline & & $\begin{array}{l}\text { \% within Pozíció } \\
\text { szintje }\end{array}$ & $69.3 \%$ & $15.9 \%$ & $14.8 \%$ & $100.0 \%$ \\
\hline & & \% within KLASZTER & $20.1 \%$ & $16.1 \%$ & $7.8 \%$ & $15.8 \%$ \\
\hline
\end{tabular}




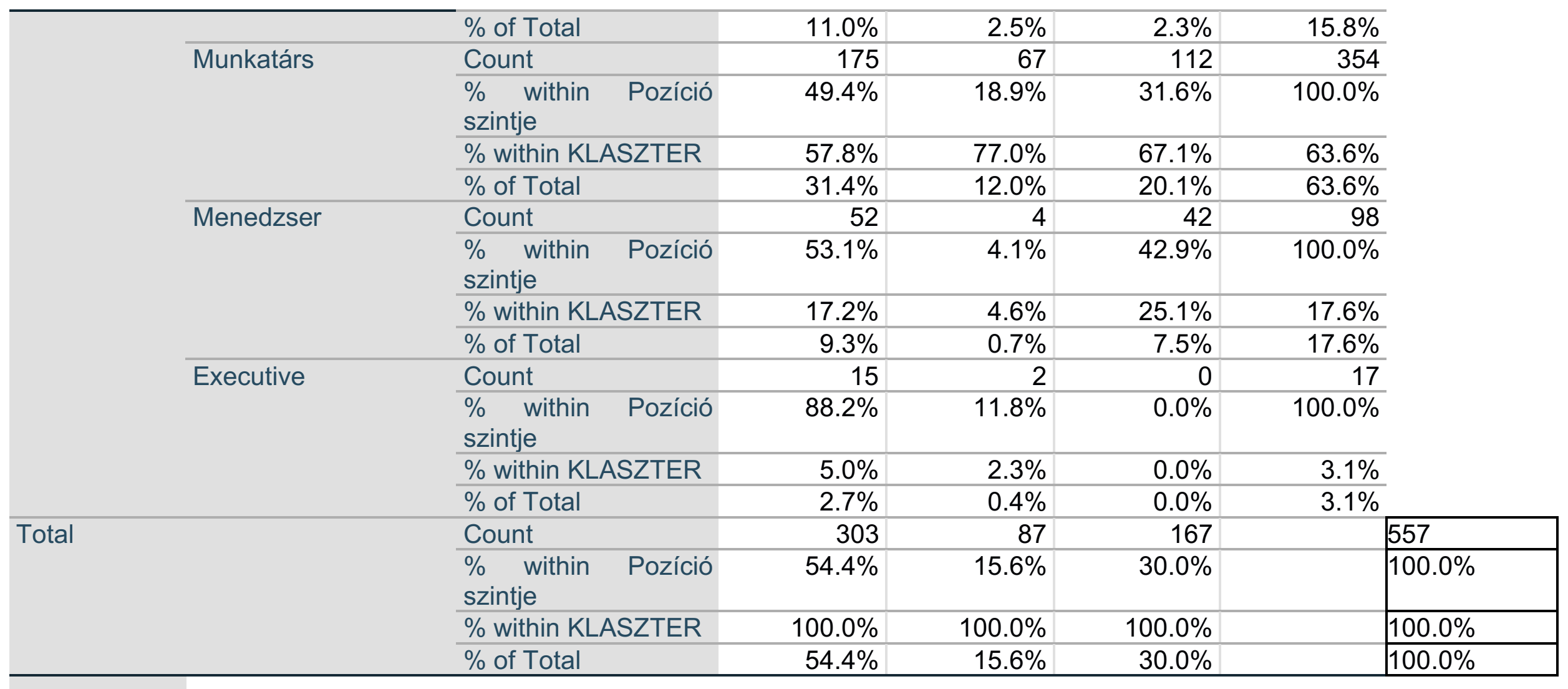




\section{Chi-Square Tests}

\begin{tabular}{lr|rrr} 
& & & $\begin{array}{c}\text { Asymptotic } \\
\text { Significance (2- } \\
\text { sided) }\end{array}$ \\
\hline Vealue & df & & .000 \\
\hline Likelihood Ratio & $37.441^{a}$ & 6 & .000 \\
\hline $\begin{array}{l}\text { Linear-by-Linear } \\
\text { Association }\end{array}$ & 46.036 & 6 & .182 \\
\hline N of Valid Cases & 1.785 & & 1 & \\
\hline
\end{tabular}

a. 1 cells $(8.3 \%)$ have expected count less than 5 . The minimum expected count is 2.66 .

\section{Symmetric Measures}

\begin{tabular}{llr|r} 
& & \multicolumn{1}{c}{$\begin{array}{c}\text { Approximate } \\
\text { Significance }\end{array}$} \\
\hline Nominal by Nominal & Phi & .259 & .000 \\
\cline { 2 - 4 } & Cramer's V & .183 & .000 \\
\cline { 2 - 4 } & Contingency Coefficient & .251 & .000 \\
\hline \multirow{2}{*}{ N of Valid Cases } & & 557 & \\
\hline
\end{tabular}




\section{Szektor * KLASZTER}

\begin{tabular}{|c|c|c|c|c|c|c|}
\hline & & & Crosstab & & & \\
\hline & & & $\begin{array}{c}\text { Marketing } \\
\text { végzettségű }\end{array}$ & $\begin{array}{l}\text { KLASZTER } \\
\text { Mérnök- } \\
\text { informatikai } \\
\text { végzettségű }\end{array}$ & SEO szakértő & Total \\
\hline Szektor & Termelő & Count & 75 & 19 & 19 & 113 \\
\hline & & \% within Szektor & $66.4 \%$ & $16.8 \%$ & $16.8 \%$ & $100.0 \%$ \\
\hline & & $\begin{array}{ll}\text { \% } & \text { within } \\
\text { KLASZTER } & \end{array}$ & $25.3 \%$ & $23.8 \%$ & $12.0 \%$ & $21.2 \%$ \\
\hline & & $\%$ of Total & $14.0 \%$ & $3.6 \%$ & $3.6 \%$ & $21.2 \%$ \\
\hline & Szolgáltató & Count & 110 & 26 & 78 & 214 \\
\hline & & \% within Szektor & $51.4 \%$ & $12.1 \%$ & $36.4 \%$ & $100.0 \%$ \\
\hline & & $\begin{array}{ll}\text { \% } & \text { within } \\
\text { KLASZTER } & \end{array}$ & $37.2 \%$ & $32.5 \%$ & $49.4 \%$ & $40.1 \%$ \\
\hline & & $\%$ of Total & $20.6 \%$ & $4.9 \%$ & $14.6 \%$ & $40.1 \%$ \\
\hline & Kereskedő & Count & 61 & 26 & 44 & 131 \\
\hline & & \% within Szektor & $46.6 \%$ & $19.8 \%$ & $33.6 \%$ & $100.0 \%$ \\
\hline & & $\begin{array}{ll}\% & \text { within } \\
\text { KLASZTER } & \end{array}$ & $20.6 \%$ & $32.5 \%$ & $27.8 \%$ & $24.5 \%$ \\
\hline & & $\%$ of Total & $11.4 \%$ & $4.9 \%$ & $8.2 \%$ & $24.5 \%$ \\
\hline & Ügynökség & Count & 33 & 7 & 16 & 56 \\
\hline & & \% within Szektor & $58.9 \%$ & $12.5 \%$ & $28.6 \%$ & $100.0 \%$ \\
\hline & & $\begin{array}{l}\% \\
\text { KLASZTER }\end{array}$ & $11.1 \%$ & $8.8 \%$ & $10.1 \%$ & $10.5 \%$ \\
\hline
\end{tabular}




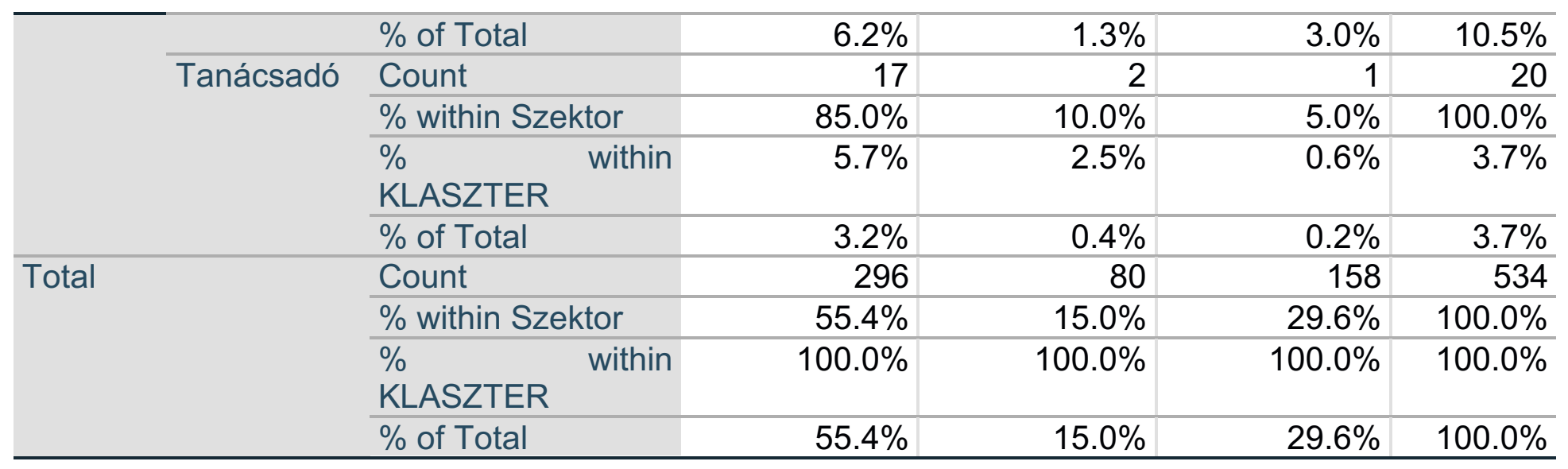

\section{Chi-Square Tests}

\begin{tabular}{|c|c|c|c|}
\hline & Value & df & $\begin{array}{l}\text { Asymptotic } \\
\text { Significance (2- } \\
\text { sided) }\end{array}$ \\
\hline Pearson Chi-Square & $26.684^{a}$ & 8 & .001 \\
\hline Likelihood Ratio & 29.235 & 8 & .000 \\
\hline $\begin{array}{l}\text { Linear-by-Linear } \\
\text { Association }\end{array}$ & .082 & 1 & .775 \\
\hline $\mathrm{N}$ of Valid Cases & 534 & & \\
\hline
\end{tabular}

a. 1 cells $(6.7 \%)$ have expected count less than 5 . The minimum expected count is 3.00 . 


\section{Symmetric Measures}

\begin{tabular}{llr|r} 
& & & \multicolumn{1}{c}{$\begin{array}{c}\text { Approximate } \\
\text { Significance }\end{array}$} \\
\hline Nominal by Nominal & Phi & .224 & .001 \\
\cline { 2 - 4 } & Cramer's V & .158 & .001 \\
\cline { 2 - 4 } & Contingency Coefficient & .218 & .001 \\
\hline N of Valid Cases & & 534 & \\
\hline
\end{tabular}

\section{Vevőkör * KLASZTER}

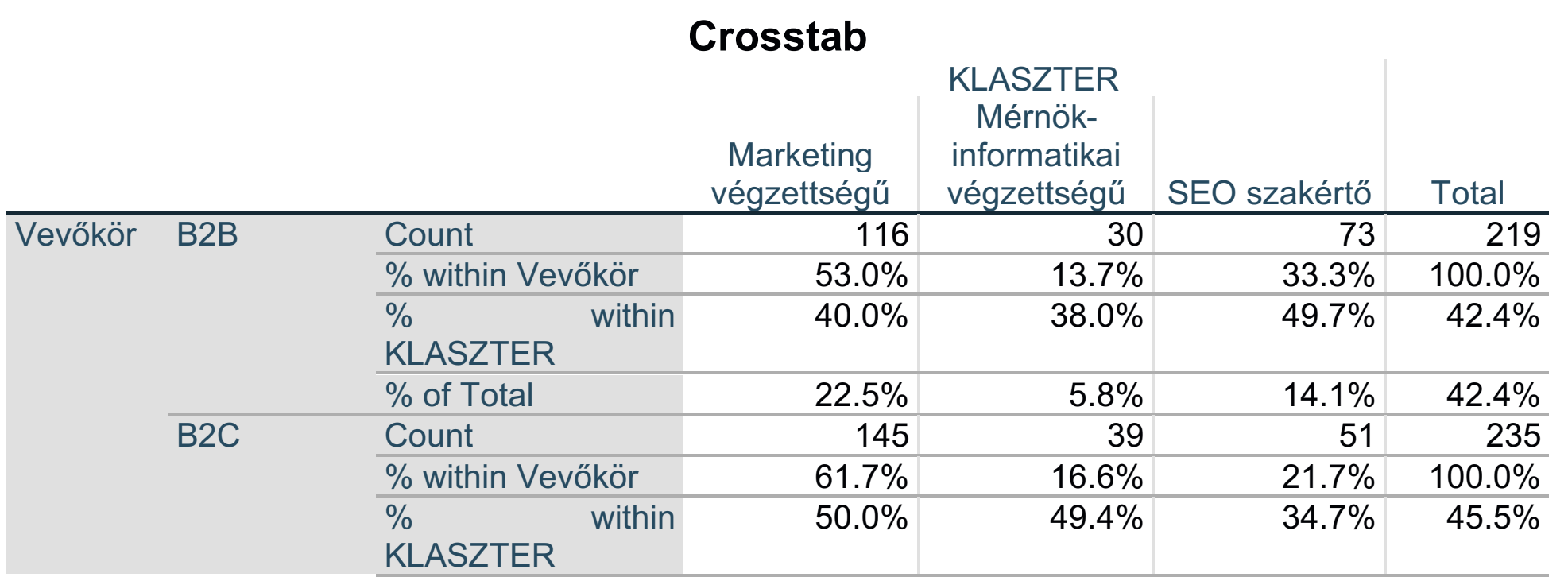




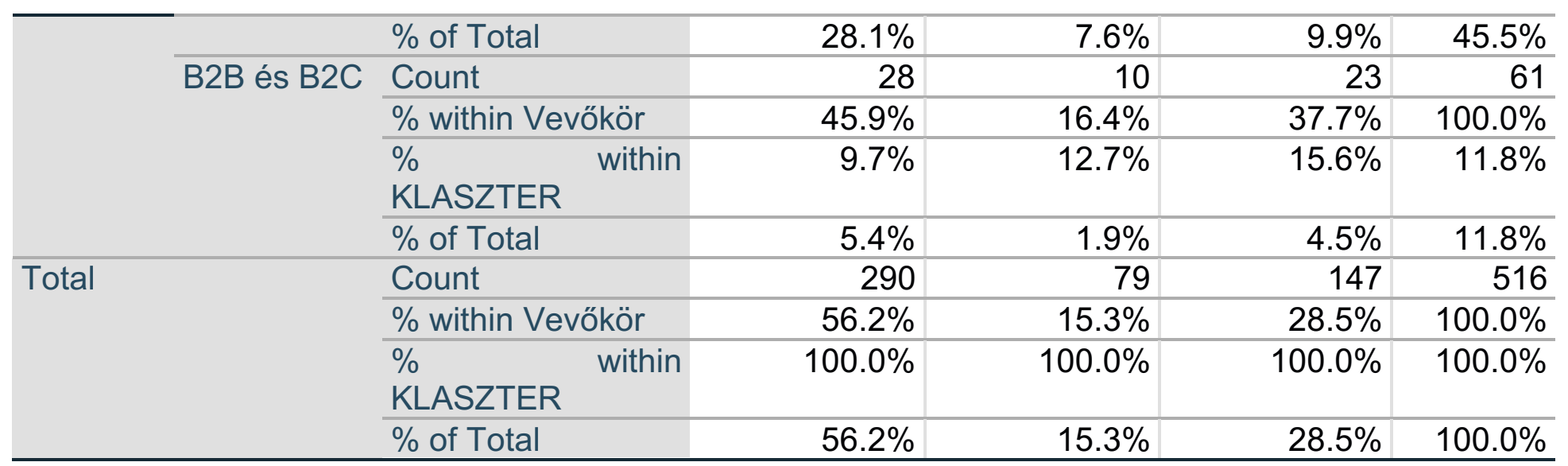

\section{Chi-Square Tests}

\begin{tabular}{lr|rrr} 
& Value & df & & $\begin{array}{c}\text { Asymptotic } \\
\text { Significance (2- } \\
\text { sided) }\end{array}$ \\
\hline Pearson Chi-Square & $11.698^{\mathrm{a}}$ & 6 & .069 \\
\hline Likelihood Ratio & 12.203 & 6 & .058 \\
\hline $\begin{array}{l}\text { Linear-by-Linear } \\
\text { Association }\end{array}$ & .286 & & 1 & .593 \\
\hline N of Valid Cases & 516 & & \\
\hline
\end{tabular}

a. 0 cells $(0 \%)$ have expected count less than 5 . The minimum expected count is .15 . 


\section{Symmetric Measures}

\begin{tabular}{llr|r} 
& & \multicolumn{1}{c}{$\begin{array}{c}\text { Approximate } \\
\text { Significance }\end{array}$} \\
\hline Nominal by Nominal & Phi & .151 & .069 \\
\cline { 2 - 4 } & Cramer's V & .106 & .069 \\
\cline { 2 - 4 } & Contingency Coefficient & .149 & .069 \\
\hline N of Valid Cases & & 516 & \\
\hline
\end{tabular}

\section{Tulajdonosi háttér * KLASZTER}

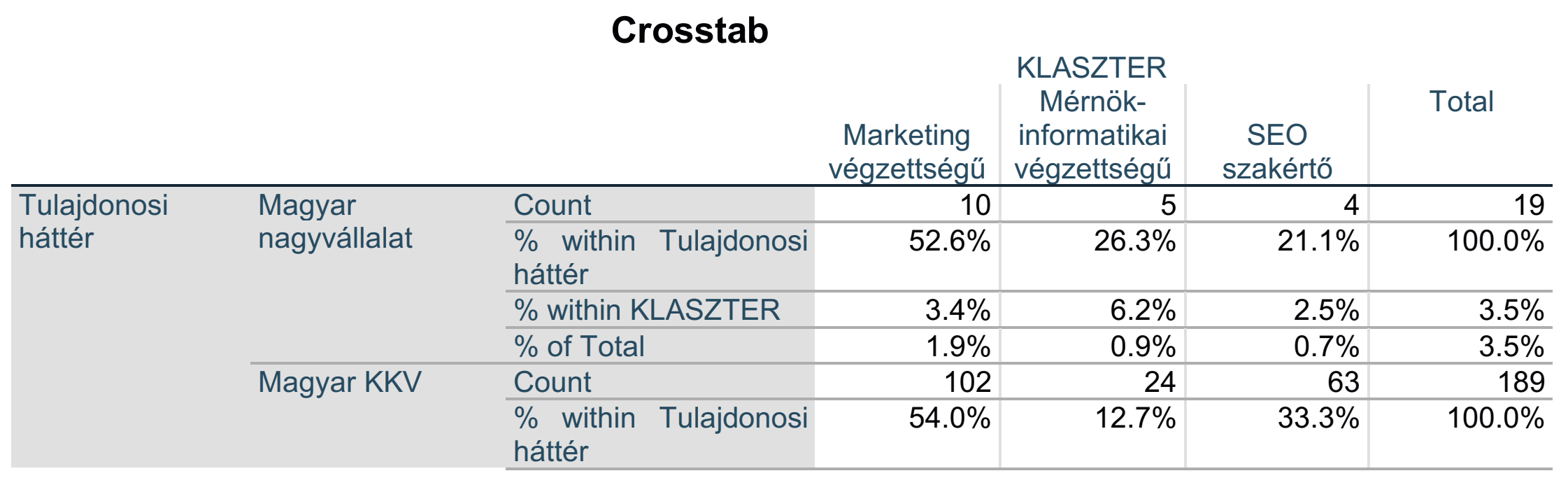




\begin{tabular}{|c|c|c|c|c|c|c|}
\hline & & \% within KLASZTER & $34.2 \%$ & $29.6 \%$ & $39.9 \%$ & $35.2 \%$ \\
\hline & & $\%$ of Total & $19.0 \%$ & $4.5 \%$ & $11.7 \%$ & $35.2 \%$ \\
\hline & Külföldi tulajdonú & Count & 170 & 43 & 87 & 300 \\
\hline & & $\begin{array}{l}\% \text { within Tulajdonosi } \\
\text { háttér }\end{array}$ & $56.7 \%$ & $14.3 \%$ & $29.0 \%$ & $100.0 \%$ \\
\hline & & $\%$ within KLASZTER & $57.0 \%$ & $53.1 \%$ & $55.1 \%$ & $55.9 \%$ \\
\hline & & $\%$ of Total & $31.7 \%$ & $8.0 \%$ & $16.2 \%$ & $55.9 \%$ \\
\hline & Egyéb & Count & 16 & 9 & 4 & 29 \\
\hline & & $\begin{array}{l}\% \text { within Tulajdonosi } \\
\text { háttér }\end{array}$ & $55.2 \%$ & $31.0 \%$ & $13.8 \%$ & $100.0 \%$ \\
\hline & & \% within KLASZTER & $5.4 \%$ & $11.1 \%$ & $2.5 \%$ & $5.4 \%$ \\
\hline & & $\%$ of Total & $3.0 \%$ & $1.7 \%$ & $0.7 \%$ & $5.4 \%$ \\
\hline Total & & Count & 298 & 81 & 158 & 537 \\
\hline & & $\begin{array}{l}\% \text { within Tulajdonosi } \\
\text { háttér }\end{array}$ & $55.5 \%$ & $15.1 \%$ & $29.4 \%$ & $100.0 \%$ \\
\hline & & \% within KLASZTER & $100.0 \%$ & $100.0 \%$ & $100.0 \%$ & $100.0 \%$ \\
\hline & & $\%$ of Total & $55.5 \%$ & $15.1 \%$ & $29.4 \%$ & $100.0 \%$ \\
\hline
\end{tabular}




\section{Chi-Square Tests}

\begin{tabular}{|c|c|c|c|}
\hline & Value & $\mathrm{df}$ & $\begin{array}{c}\text { Asymptotic } \\
\text { Significance (2- } \\
\text { sided) }\end{array}$ \\
\hline Pearson Chi-Square & $11.349^{a}$ & 6 & .078 \\
\hline Likelihood Ratio & 10.550 & 6 & .103 \\
\hline $\begin{array}{l}\text { Linear-by-Linear } \\
\text { Association }\end{array}$ & .921 & 1 & .337 \\
\hline $\mathrm{N}$ of Valid Cases & 537 & & \\
\hline
\end{tabular}

a. 2 cells $(16.7 \%)$ have expected count less than 5 . The minimum expected count is 2.87 .

\section{Symmetric Measures}

\begin{tabular}{lll|r} 
& & \multicolumn{1}{c}{$\begin{array}{c}\text { Approximate } \\
\text { Significance }\end{array}$} \\
\hline Nominal by Nominal & Phi & .145 & .078 \\
\cline { 2 - 4 } & Cramer's V & .103 & .078 \\
\cline { 2 - 4 } & Contingency Coefficient & .144 & .078 \\
\hline \multirow{2}{*}{ N of Valid Cases } & & 537 & \\
\hline
\end{tabular}




\section{Gyakorlati évek száma kategorizáció * KLASZTER}

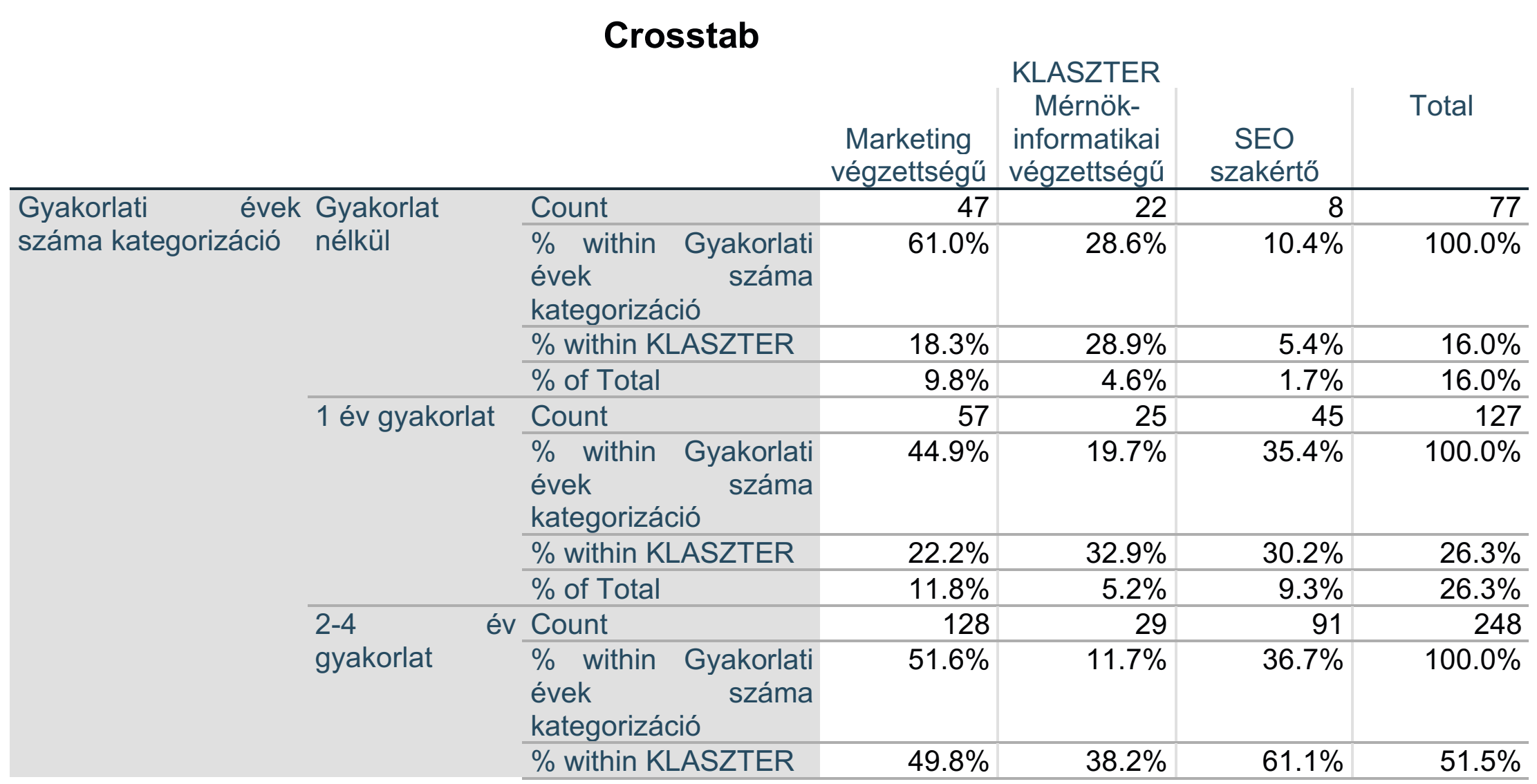




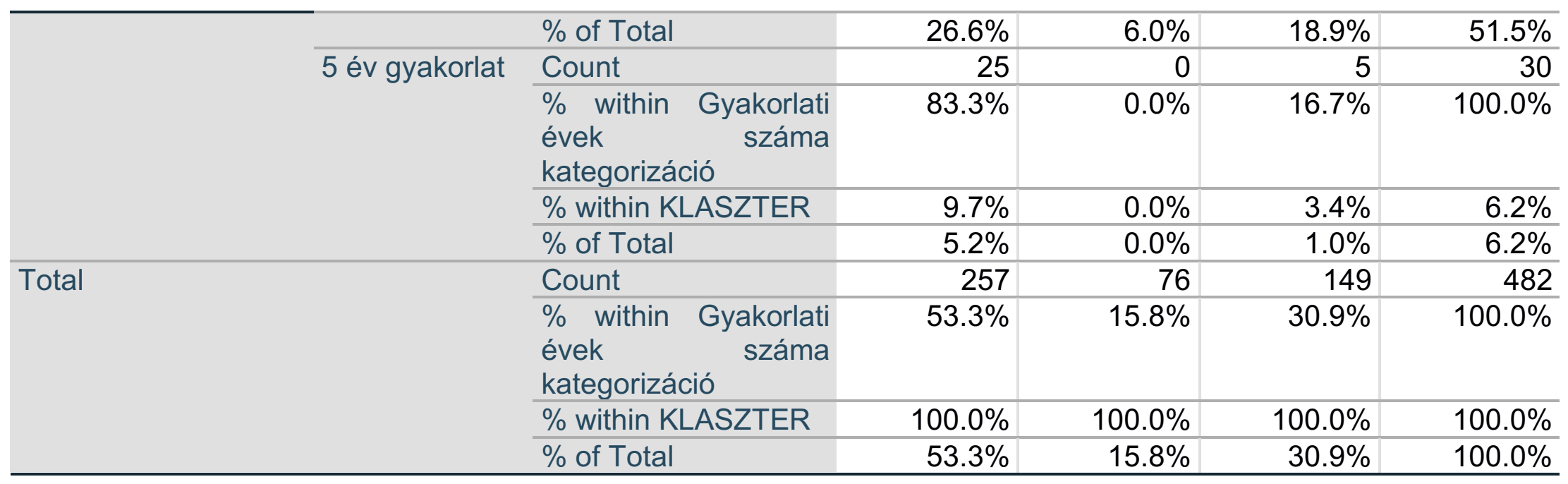

\section{Chi-Square Tests}

\begin{tabular}{|c|c|c|c|}
\hline & Value & df & $\begin{array}{c}\text { Asymptotic } \\
\text { Significance (2- } \\
\text { sided) }\end{array}$ \\
\hline Pearson Chi-Square & $40.324^{a}$ & 6 & .000 \\
\hline Likelihood Ratio & 46.843 & 6 & .000 \\
\hline $\begin{array}{l}\text { Linear-by-Linear } \\
\text { Association }\end{array}$ & .713 & 1 & .398 \\
\hline $\mathrm{N}$ of Valid Cases & 482 & & \\
\hline
\end{tabular}

a. 1 cells $(8.3 \%)$ have expected count less than 5 . The minimum expected count is 4.73 . 


\begin{tabular}{ll|rr}
\multicolumn{2}{l}{ Symmetric Measures } & \multicolumn{1}{c}{$\begin{array}{c}\text { Approximate } \\
\text { Significance }\end{array}$} \\
\hline Nominal by Nominal & Phi & .289 & .000 \\
\cline { 2 - 4 } & Cramer's V & .205 & .000 \\
\cline { 2 - 4 } & Contingency Coefficient & .278 & .000 \\
\hline N of Valid Cases & & 482 & \\
\hline
\end{tabular}

\section{Álláshirdetés típusa * KLASZTER}

\begin{tabular}{|c|c|c|c|c|c|c|}
\hline & & Crosstab & & & & \\
\hline & & & $\begin{array}{l}\text { Marketing } \\
\text { végzettségü }\end{array}$ & $\begin{array}{l}\text { KLASZTER } \\
\text { Mérnök- } \\
\text { informatikai } \\
\text { végzettségü }\end{array}$ & $\begin{array}{c}\text { SEO } \\
\text { szakértő }\end{array}$ & Total \\
\hline Álláshirdetés & Online marketinges & Count & 46 & 16 & 57 & 119 \\
\hline típusa & & $\begin{array}{l}\% \quad \text { within } \\
\text { Álláshirdetés típusa }\end{array}$ & $38.7 \%$ & $13.4 \%$ & $47.9 \%$ & $100.0 \%$ \\
\hline & & $\%$ within KLASZTER & $15.2 \%$ & $18.2 \%$ & $34.1 \%$ & $21.3 \%$ \\
\hline & & $\%$ of Total & $8.2 \%$ & $2.9 \%$ & $10.2 \%$ & $21.3 \%$ \\
\hline
\end{tabular}




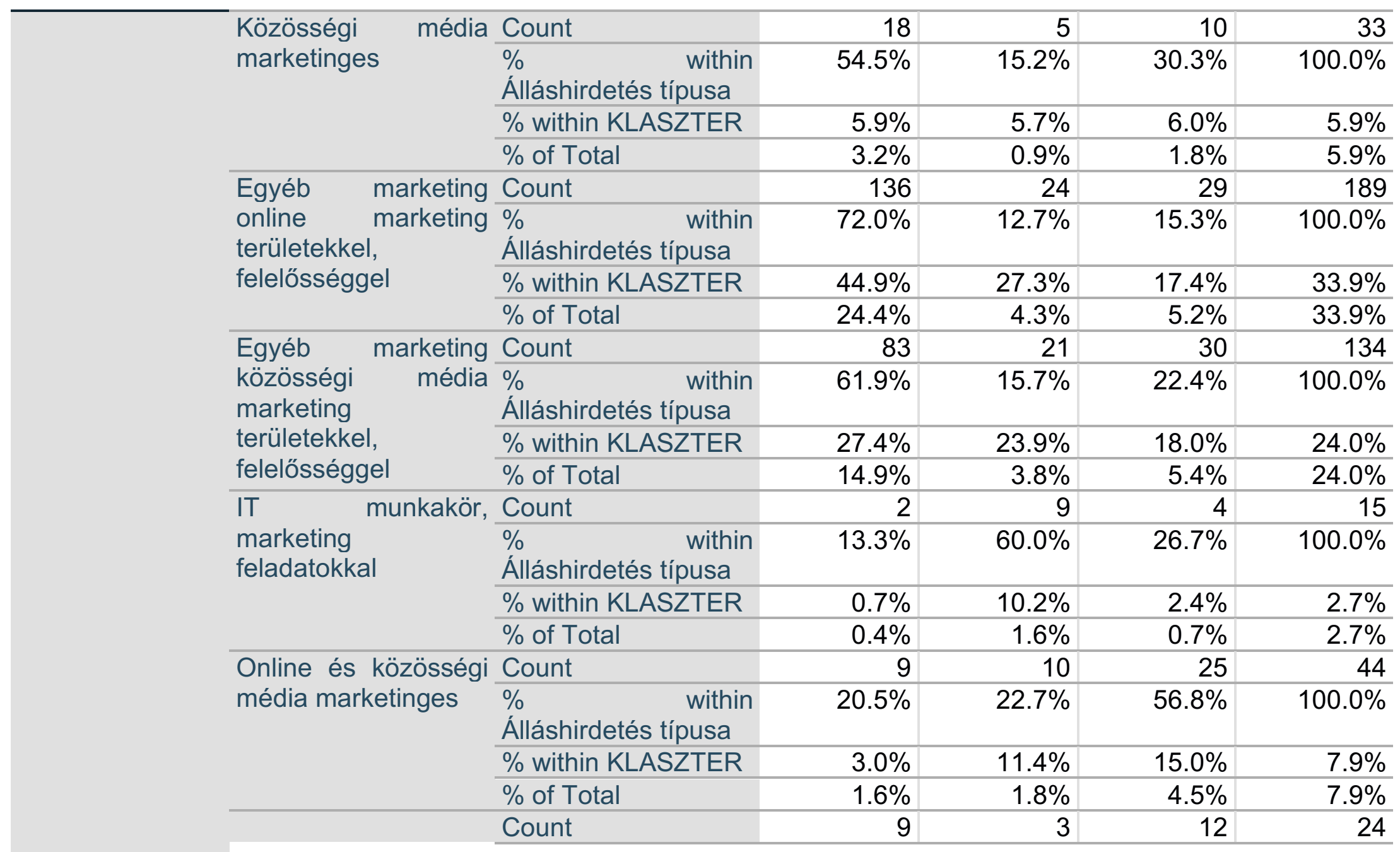




\begin{tabular}{|c|c|c|c|c|c|}
\hline & $\begin{array}{lll}\text { Egyéb } & \text { marketing, } \% & \text { within } \\
\text { online és közösségi Álláshirdetés típusa }\end{array}$ & $37.5 \%$ & $12.5 \%$ & $50.0 \%$ & $100.0 \%$ \\
\hline & média területekkel, \% within KLASZTER & $3.0 \%$ & $3.4 \%$ & $7.2 \%$ & $4.3 \%$ \\
\hline & felelősséggel $\quad \%$ of Total & $1.6 \%$ & $0.5 \%$ & $2.2 \%$ & $4.3 \%$ \\
\hline \multirow[t]{4}{*}{ Total } & Count & 303 & 88 & 167 & 558 \\
\hline & $\begin{array}{l}\text { \% within } \\
\text { Álláshirdetés típusa }\end{array}$ & $54.3 \%$ & $15.8 \%$ & $29.9 \%$ & $100.0 \%$ \\
\hline & \% within KLASZTER & $100.0 \%$ & $100.0 \%$ & $100.0 \%$ & $100.0 \%$ \\
\hline & $\%$ of Total & $54.3 \%$ & $15.8 \%$ & $29.9 \%$ & $100.0 \%$ \\
\hline
\end{tabular}

\section{Chi-Square Tests}

\begin{tabular}{lr|r|r} 
& Value & df & \multicolumn{2}{|c}{$\begin{array}{c}\text { Asymptotic } \\
\text { Significance (2- } \\
\text { sided) }\end{array}$} \\
\hline Pearson Chi-Square & $97.225^{a}$ & 12 & .000 \\
\hline Likelihood Ratio & 92.407 & 12 & .000 \\
\hline $\begin{array}{l}\text { Linear-by-Linear } \\
\text { Association }\end{array}$ & 2.913 & 1 & .088 \\
\hline N of Valid Cases & 558 & & \\
\hline
\end{tabular}

a. 3 cells $(14.3 \%)$ have expected count less than 5 . The minimum expected count is 2.37 . 


\section{Symmetric Measures}

\begin{tabular}{llr|r} 
& & Value & $\begin{array}{c}\text { Approximate } \\
\text { Significance }\end{array}$ \\
\hline Nominal by Nominal & Phi & .417 & .000 \\
\cline { 2 - 4 } & Cramer's V & .295 & .000 \\
\cline { 2 - 4 } & Contingency Coefficient & .385 & .000 \\
\hline N of Valid Cases & & 558 & \\
\hline
\end{tabular}


5. Tudásváltozók összevonása

\begin{tabular}{|l|l|l|l|l|}
\hline Grafika & Programozás/IT & Webes eszközök & Egyéb marketing & Keresőmarketing \\
\hline Adobe & UX & Adserver & Copywriting & PPC \\
\hline Flash & HTML & Joomla & szövegírás & Adwords \\
\hline Indesign & XML & Wordpress & & SEO \\
\hline Dreamweaver & CSS & Drupal & & \\
\hline Photoshop & PHP & & & \\
\hline Final Cut & SQL & & & \\
\hline Premier Pro & & & & \\
\hline Corel & & & & \\
\hline
\end{tabular}

